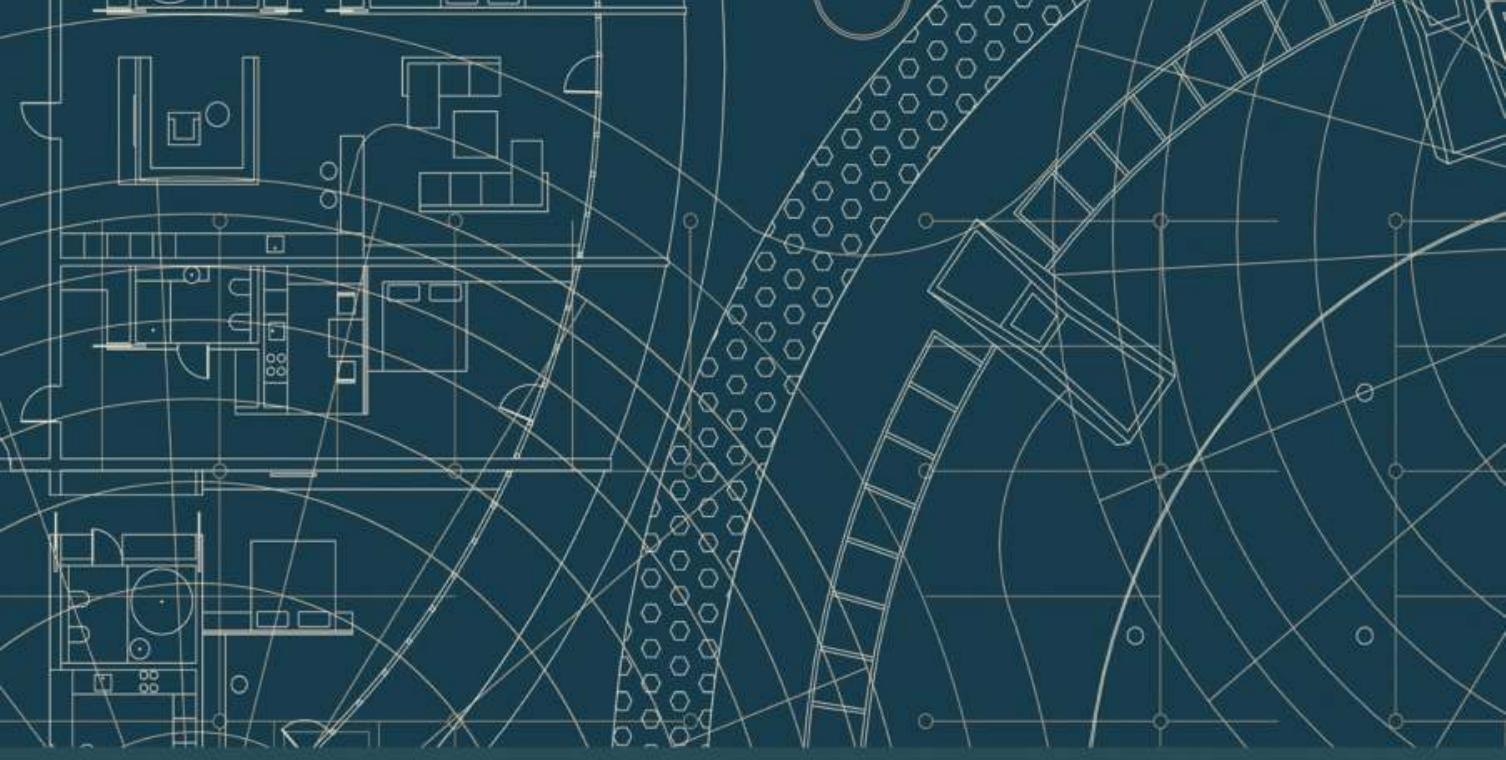

Routledge Advances in Korean Studies

\title{
EXPORTING URBAN KOREA?
}

\section{RECONSIDERING THE KOREAN URBAN DEVELOPMENT EXPERIENCE}

Edited by

Se Hoon Park, Hyun Bang Shin

and Hyun Soo Kang 


\section{Exporting Urban Korea?}

A detailed examination of the "Korean development model" from its urban dimension, evaluating its sociopolitical contexts and implications for international development cooperation.

There is an increasing tendency to use the development experience of Asian countries as a reference point for other countries in the Global South. Korea's condensed urbanization and industrialization, accompanied by the expansion of new cities and industrial complexes across the country, have become one such model, even if the fruits of such development may not have been equitably shared across geographies and generations. The chapters in this book critically reassess the Korean urban development experience from regional policy to new town development, demonstrating how these policy experiences were deeply rooted in Korea's socioeconomic environment and discussing what can be learned from them when applying them in other developmental contexts.

This book will be of great interest to scholars and researchers in the field of urban studies and developmental studies in general, and Korea's (urban) development experience in particular.

Se Hoon Park is Director of the Global Development Partnership Center, Korea Research Institute for Human Settlements (KRIHS), Republic of Korea.

Hyun Bang Shin is Professor of Geography and Urban Studies in the Department of Geography and Environment at the London School of Economics and Political Science (LSE), UK.

Hyun Soo Kang is President at the Korea Research Institute for Human Settlements (KRIHS), Republic of Korea. 


\title{
Routledge Advances in Korean Studies
}

\author{
41. Megacity Seoul \\ Urbanization and the Development of Modern South Korea \\ $\mathrm{Yu}-\mathrm{Min}$ Joo
}

42. Korean Adoptees and Transnational Adoption

Embodiment and Emotion

Jessica Walton

\section{Digital Development in Korea, Second Edition}

Lessons for a Sustainable World

Myung Oh and James F. Larson

44. The State, Class and Developmentalism in South Korea

Development as Fetish

Hae-Yung Song

\section{Development Prospects for North Korea}

Edited by Tae Yong Jung and Sung Jin Kang

\section{The Road to Multiculturalism in South Korea}

Ideas, Discourse, and Institutional Change in a Homogenous Nation-State Timothy C. Lim

47. Healing Historical Trauma in South Korean Film and Literature Chungmoo Choi

\section{Exporting Urban Korea?}

Reconsidering the Korean Urban Development Experience

Se Hoon Park, Hyun Bang Shin and Hyun Soo Kang

For more information about this series, please visit: www.routledge.com/ Routledge-Advances-in-Korean-Studies/book-series/SE0505 


\section{Exporting Urban Korea? Reconsidering the Korean Urban Development Experience}

\section{Edited by}

Se Hoon Park, Hyun Bang Shin and Hyun Soo Kang 
First published in English 2021

by Routledge

2 Park Square, Milton Park, Abingdon, Oxon OXI4 4RN

and by Routledge

52 Vanderbilt Avenue, New York, NY 10017

Routledge is an imprint of the Taylor \& Francis Group, an informa business

(C) 2021 selection and editorial matter, Se Hoon Park, Hyun Bang Shin and Hyun Soo Kang; individual chapters, the contributors

The right of Se Hoon Park, Hyun Bang Shin and Hyun Soo Kang to be identified as the authors of the editorial material, and of the authors for their individual chapters, has been asserted in accordance with sections 77 and 78 of the Copyright, Designs and Patents Act 1988.

All rights reserved. No part of this book may be reprinted or reproduced or utilised in any form or by any electronic, mechanical, or other means, now known or hereafter invented, including photocopying and recording, or in any information storage or retrieval system, without permission in writing from the publishers.

Trademark notice: Product or corporate names may be trademarks or registered trademarks, and are used only for identification and explanation without intent to infringe.

British Library Cataloguing-in-Publication Data

A catalogue record for this book is available from the British Library

Library of Congress Cataloging-in-Publication Data

A catalog record has been requested for this book

ISBN: 978-0-367-49840-5 (hbk)

ISBN: 978-1-003-04759-9 (ebk)

Typeset in Galliard

by Newgen Publishing UK 


\section{Contents}

List of figures vii

List of tables viii

List of contributors $\quad$ ix

Acknowledgments $\quad \mathrm{xv}$

1 Introduction: reconsidering the Korean urban development experience for international cooperation 1 SE HOON PARK, HYUN BANG SHIN AND HYUN SOO KANG

\section{PART I}

Outlining the urban transformation of Korea

2 Transformations in the governance of urban and regional planning in Korea: from (neo-)developmentalism to civic democracy, 1965-2020

MIKE DOUGLASS

3 Korea's regional development policy: understanding its context and drawing implications for international development cooperation WON BAE KIM

4 Urban transformation "Korean style": lessons from property-based urban development HYUN BANG SHIN

5 From commodities to community engagement: localities and urban development in Seoul, Korea 
vi Contents

\section{PART II}

Modeling the Korean urban development experience

6 Export urbanism: Asian emerging donors and the politics of urban development knowledge sharing JAMIE DOUCETTE AND FARWA SIAL

7 A multitude of models: transferring knowledge of the Korean development experience CUZ POTTER AND JINHEE PARK

8 International urban development leadership: Singapore, China and South Korea compared HYUNG MIN KIM, JULIE MIAO AND NICHOLAS A. PHELPS

\section{PART III}

Policies and institutions of Korean urban development

9 Exporting new city developments? From new towns to smart cities

YU-MIN JOO

10 Housing policy and urban redevelopment in contemporary Korea

SEONG-KYU HA

11 Land development schemes in South Korea: background, structure and outcome

SEOHWAN LIM

12 Knowledge-policy nexus: policy research institutes and the urban development regime in Korea SE HOON PARK

13 Engines for development: public development corporations and their role in urban development in Korea JIEUN KIM

Index 


\section{Figures}

2.1 The political dynamics of urban and regional policy in Korea, 1960-2020

2.2 National development corridor, 2011

2.3 Population growth by county, Korea 1995-2000 and 2000-2005

2.4 Spatial distribution of industrial complexes before 1990 to after 2010

3.1 Regional disparity in Korea (per capita gross regional product)

4.1 Housing Purchase Price Composite Indices (each year index is based on January $2019=100.0$ )

5.1 Property-led urban redevelopment and localities, Wangsimni New Town

5.2 Community struggles against forced evictions in Haengdang-dong

5.3 Community engagement in planning, Seowon Maeul 92

11.1 Housing Supply Ratio and Urbanization Rate 187

11.2 Land Price Fluctuation Rate (\% on year-on-year basis) 188

12.1 Composition of KRIHS budget (2017) by source (left) and the types of research projects between 2009 and 2018 (right)

13.1 Location of land reclamation projects

13.2 KHC debt and capital 1999-2008

13.3 LDC debt and capital 1999-2008

13.4 Construction orders: domestic vs. overseas 


\section{Tables}

3.1 Distribution of population in metropolitan cities and provinces, 1960-2017

3.2 Regional distribution of production and population

3.3 Skewed distribution of large corporations, professionals and R\&D personnel in Korea

3.4 Evolution of regional policy in Korea

4.1 Distribution of redevelopment flats per use in designated redevelopment districts in Korea

5.1 Evolving place-based grassroots struggles in Seoul

5.2 Comparison of community movements in Songhak Maeul and Seowon Maeul

6.1 Examples of bilateral KSP consultations concerning urban development

7.1 Relative importance of apartment characteristics in Hanoi and Korea

7.2 Housing priorities in Hanoi and Korea 127

9.1 Korea's ten innovation cities 153

10.1 Indicators of housing conditions (1980-2015) 169

10.2 Current status of housing stock by type in 2017 (in 1,000s) 174

11.1 Urbanization rate in South Korea, 1950-2010 183

11.2 Land development by LR (project completion, $\mathrm{km}^{2}$ ) 186

11.3 Compensation in PPD, a comparison between two projects in different times

11.4 Land development methods in South Korea 196

12.1 Policy research institutes under the NRC in Korea 205

12.2 Types of policy research institutes in Korea 207

12.3 Changes in the governance of KRIHS 210

12.4 Roles of actors in the MAC Construction Project 214

13.1 Legal basis for PDCs 219

13.2 Total assets of Top 10 chaebols and Top 10 PDCs (2015) 220 


\section{Contributors}

Jamie Doucette is Senior Lecturer in Human Geography, Department of Geography, The University of Manchester, also serves as Chair of the Cities, Politics, Economies Research Group and is a member of the senior leadership team of the Manchester Urban Institute. His interests include the geographical political economy of development and democratization, the nexus between developmentalism and urban space, and labor geography. He teaches courses on geographies of globalization and Asian labor studies. He has published widely in geography and Asian Studies, with articles in Progress in Human Geography, Transactions of the Institute of British Geographers, Political Geography, Journal of Asian Studies, Journal of Korean Studies, Critical Asian Studies, and elsewhere. His research has won awards, such as the Journal of Contemporary Asia Prize 2017 and a Leverhulme Trust Research Fellowship. He is the editor (with Bae-Gyoon Park) of Developmentalist Cities? Interrogating Urban Developmentalism in East Asia (Brill, 2019).

Mike Douglass is Emeritus Professor and former Chair of the Department of Urban and Regional Planning, University of Hawai'i, and former Director of the Globalization Research Center. He received his $\mathrm{PhD}$ in urban planning from UCLA. From 2012-2018 at the National University of Singapore, he was Professor and Leader of the Asian Urbanisms Cluster in the Asian Research Institute and Professor of Sociology in the LKY School of Public Policy. He has held senior positions in the United Nations and has been a consultant for major international donor agencies as well as national and local governments in Asia. His recent publications include The Rise of Progressive Cities East and West (Springer Singapore, 2019), Cities in Asia by and for the People (Amsterdam University Press, 2018), Disaster Justice in Urbanising Asia-Pacific (Springer Singapore, 2018) and Disaster Governance in Urbanising Asia (2016).

Seong-Kyu Ha is Professor Emeritus, Department of Urban Planning and Real Estate, Chung-Ang University, South Korea. He also serves as President of the Korea Research Institute of Housing Management. He received his PhD in urban planning from University College London and an MSc from the London School of Economics. His current research interests have centered on low-income housing policies, urban residential regeneration and housing 
management. He has authored numerous publications on housing policy and urban and community regeneration, including Housing Policy, Wellbeing and Social Development in Asia (with Rebecca L. H. Chiu, Routledge, 2018). Recently he was elected Chairman of the Korea Housing Service Society, a housing expert consulting and research group in Korea. He is on the Board of Directors of the Korea Land and Housing Corporation.

Yu-Min Joo is Associate Professor, KDI School of Public Policy and Management (KDIS) in South Korea. Prior to joining KDIS, she was an Assistant Professor at the Lee Kuan Yew School of Public Policy, National University of Singapore, from 2012 to 2019. She holds a $\mathrm{PhD}$ in urban and regional planning from the Massachusetts Institute of Technology and a Master's in urban planning from Harvard University. She researches and publishes on urban development and policy issues in Asia, particularly on the topics of urban governance, smart cities, megaprojects and mega-events. Her latest books include Megacity Seoul: Urbanization and the Development of Modern South Korea (Routledge, 2019) and Smart Cities in Asia: Governing Development in the Era of Hyper-Connectivity (co-edited with Teck-Boon Tan, Edward Elgar Publishing, 2020).

Hyun Soo Kang is President, Korea Research Institute for Human Settlements (KRIHS). He holds a PhD in urban planning from Seoul National University, Korea. Before he joined KRIHS, he was a Professor at Jungbu University, President of the Chungnam Research Institute (2013-2018) and President of the Korean Association of Space and Environmental Research (2010). Working as a commentator on regional policies in Korea, he talks and writes about various planning issues in Korean cities, such as regional balanced development, local autonomy and the right to the city. He has authored The Urban Policies in an Age of Austerity (Hanul Academy, 2013) and The Right to the City (Chaeksesang, 2010), among other publications.

Hyung Min Kim is Senior Lecturer in the Faculty of Architecture, Building and Planning, The University of Melbourne. He was full-time Lecturer (equivalent to Assistant Professor) at RMIT University (Melbourne, Australia) and Xian Jiaotong-Liverpool University (Suzhou, China). He completed his PhD at the University of Melbourne, supported by the Endeavour Postgraduate Award, a competitive scholarship. His teaching and research activities focus on the economic and spatial dynamics of cities. His research has addressed globalization and global cities, urban and environmental economics, livability, land policy, planning issues in the Asia-Pacific region, foreign direct investment-led urban growth and international real estate investment. His research findings have appeared in prestigious peer-reviewed international journals, including Progress in Planning, Cities, Habitat International, and Land Use Policy.

Jieun Kim is Research Fellow, SH Urban Research Office, Seoul Housing and Communities Corporation and Principle Researcher at the SH Urban Research Center at the Seoul Housing and Communities Corporation, the largest 
supplier of public rental housing in Seoul. She received her $\mathrm{PhD}$ in urban planning and policy from the University of Illinois at Chicago and a Master's degree in urban design from Seoul National University. Her research focuses on neighborhood revitalization, social housing policy, and international development. Her interests center on the contradictory role of public development corporations, policy-driven gentrification in low-income neighborhoods and the possibility of equitable urban development approaches. Throughout her career, she has participated in several international development projects in Algeria, Egypt, Mongolia and the Philippines.

Su Kim, holds a Master's degree in urban and regional planning from the Graduate School of Environmental Studies, Seoul National University. She majored in German studies, Political Science and International Relations from Yonsei University in Seoul, Korea. Her research interests include urban studies, community development, and civic engagement in urban planning. She is currently participating in the 2040 Seoul Plan research team at the Seoul Institute.

Won Bae Kim, Former Senior Research Fellow, Korea Research Institute for Human Settlements has worked at the Korea Research Institute for Human Settlements as well as the East-West Center in Hawai'i. He has taught at the University of Hawai'i, Dong-A University, Chung-Ang University and Yonsei University. He obtained his $\mathrm{PhD}$ from the University of Wisconsin and Master's degrees from the Graduate School of Design, Harvard University, as well as the Graduate School of Environmental Studies, Seoul National University. His research covers both intranational and international regional development. His recent publications include Northeast Asia's Shaking Strategic Landscape: Searching for the Future of the Korean Peninsula (Nanam Publisher, 2018, in Korean), Collaborative Regional Development in Northeast Asia: Towards Sustainable Regional and Sub-regional Futures (co-editor, Chinese University Press, 2011). His earlier works include Culture and the City in East Asia (co-editor, Oxford University Press, 1997) and Asian NIEs and the Global Economy (co-editor, Johns Hopkins University Press, 1995). He has contributed many articles to professional journals and books.

Blaž Križnik is Associate Professor at the Graduate School of Urban Studies, Hanyang University, Seoul. He received his $\mathrm{PhD}$ in sociology from the University of Ljubljana. He has worked as Visiting Research Fellow at the IaaC in Barcelona, the Seoul Development Institute and the Seoul National University Asia Center. He is a researcher at the Institute for Spatial Policies and a member of the Centre for Korean Studies at the University of Ljubljana. His research work is focused on comparative urban studies, urban social movements and Korean studies. His books include Local Responses to Global Challenges: Cultural Context of Urban Change in Barcelona and Seoul (FDV, 2009) and Community-Based Urban Development: Evolving Urban Paradigms in Singapore and Seoul (with Im Sik Cho, Springer, 2017). 
Seohwan Lim is Former Senior Research Fellow at the LH Research Institute and spent most of his career working for the Korea Land and Housing Corporation (KLDC), where he worked on site planning for apartment complexes and conducted research on housing and urban issues. After retiring from KLDC, he worked for an architectural design company and then for the Ministry of Housing, Construction and Sanitation of Peru as an advisor on urban development. He majored in architecture and urban planning at Seoul National University and studied urban development at University College London. He interested in the political-economic aspects of housing and urban development and is currently involved in a study group on urban issues.

Julie Miao is Senior Lecturer in Property and Economic Development at the Faculty of Architecture, Building and Planning, University of Melbourne, and an Honorary Fellow at Shanghai Jiao Tong and Henan Universities, China. In 2017, she held a Visiting Fellowship at Hong Kong University. Previously, she was a Lecturer in Urban Planning and Development at Glasgow University and a Research Fellow at the University of St Andrews. Dr. Miao studied economic geography and planning at University College London. Her research has developed along two innovative fields: the "intrapreneurial state" and the interface between housing, labor and the knowledge economy. In particular, Dr. Miao has explored the intersection between these two fields using multidisciplinary approaches, achieving several impactful research outcomes. Her publications include Making 21st Century Knowledge Complexes (Routledge, 2016), “The intrapreneurial state: Singapore's emergence in the smart and sustainable urban solutions field" (Territory, Politics, Governance, 2019), and "Varieties of urban entrepreneurialism" (Dialogues in Human Geography, 2019).

Jinhee Park is an independent researcher and holds a PhD in urban studies and planning from the University of Sheffield. She was a Postdoc Fellow at the Global Research Institute, Korea University, and a Visiting Scholar at the Centre for Global Development, University of Leeds, UK. She has also worked with the Korea Land and Housing Institute and the Korea Research Institute for Human Settlements. Her current research focuses on large urban developments under capitalism. In this research, she addresses the roles of real estate developers, cultural and institutional economy and transnational developments, and the ways in which they transform and shape urban life socially, spatially, economically, politically and culturally.

Se Hoon Park is a researcher and commentator on the planning and politics of Korea cities and is currently Director of the Global Development Partnership Center, Korea Research Institute for Human Settlements, Korea. He studied urban studies and planning at Seoul National University and the University of Tokyo. Having been involved in numerous national urban projects in Korea, he has talked and written on urban development, the cultural city and ethnic enclaves in Korean and East Asian cities. Recently he has focused on 
development cooperation in collaboration with international organizations such as UN Habitat, the World Bank and the Inter-American Development Bank. His publications include Beyond Creative Cities (Nanam, 2014), "Can we implant an artist community? A reflection on government led cultural districts in Korea" (published in the journal, Cities, 2016), and "Seoul" in The Wiley-Blackwell Encyclopedia of Urban and Regional Studies (Wiley, 2019).

Nicholas A. Phelps is Chair of Urban Planning and Associate Dean (International) at the University of Melbourne. He was previously Professor of Urban and Regional Development and Pro Vice-Provost (Regional) at University College London. He is the author of over 80 international peer-reviewed journal articles. He is also author of the books Sequel to Suburbia (MIT Press, 2015) and Interplaces(OUP, 2017). His research interests cover the economic geography of multinational enterprises, urban economic agglomeration and suburban planning and politics. His research has been funded by the UK Economic and Social Research Council and the British Academy, among other funding agencies.

Cuz Potter is Associate Professor of International Development and Cooperation at Korea University's Division of International Studies. He attained his MSUP, MIA and PhD from Columbia University and his current research focuses on the role of the Korean construction industry in the uneven spatial development of developing countries, especially Myanmar and Vietnam. His past research has focused on social justice in developing and implementing infrastructure services, particularly in regard to how technological change in the logistics industry has undermined the territorial foundation of port policy in the US. He has also coauthored work on Nairobi's slums for the World Bank, US urban revitalization for the Korean government, urban entrepreneurialism in China and industrial districts. He is a co-editor of and contributor to Searching for the Just City, an interrogation of Susan Fainstein's concept of the "just city." He has consulted for a number of firms and organizations in New York City and Seoul. Prior to academia, he spent three years editing and translating for the Korean Ministries of Environment and Labor.

Hyun Bang Shin is Professor of Geography and Urban Studies, Department of Geography and Environment, London School of Economics and the Director of Saw Swee Hock Southeast Asia Centre at the London School of Economics and Political Science. His research focuses on the critical analysis of the political-economic dynamics of speculative urbanization, the politics of displacement, gentrification, mega-events and the right to the city, with particular attention to Asian cities. He has coauthored Planetary Gentrification (Polity, 2016), edited Anti-Gentrification: What Is to Be Done (Dongnyok, 2017), and co-edited Global Gentrifications: Uneven Development and Displacement (Bristol University Press, 2015) and Neoliberal Urbanism, Contested Cities and Housing in Asia (Palgrave Macmillan, 2019). He is a trustee of the Urban Studies Foundation, and is to serve the journal International Journal of Urban 


\section{xiv Contributors}

and Regional Research as incoming editor from 2021. He currently sits on the international advisor board of the journal Antipode and serves on the editorial board of the journals: International Journal of Urban and Regional Research, Urban Geography; City, Culture and Society; Space and Environment, China City Planning Review and Radical Housing Journal.

Farwa Sial is Visiting Research Fellow and an Early Career Researcher, Department of Geography, School of Environment, Education and Development, University of Manchester. She holds a $\mathrm{PhD}$ in development studies from the School of Oriental and African Studies (SOAS) and has over four years of teaching experience in the Department of Development Studies and Economics at SOAS. Her research interests lie at the intersection of political economy, industrial policy, economic geography, corporate power and international development. In addition to ongoing work on South Korea's emerging role in international development, she has undertaken research and policy work for various DFID projects in Tanzania and Pakistan. 


\section{Acknowledgments}

We wish to thank all the contributors who have shared their views on Korea's urban development experience in this book. It has been an exciting experience for the editors to work with these contributors with diverse academic backgrounds, ranging from urban planning and geography to international studies. Besides the contributors, this book is also indebted to numerous organizations and individuals. The Korea Research Institute for Human Settlements (KRIHS) supported the entire process from the inception of the project to its publication. They also generously funded the international workshop held on August 28-29, 2019 , where the contributors had a chance to share their ideas and sharpen their arguments. We wish to thank Yehyun An, Serine Jeon and Jeong Yun Hwang at KRIHS for their assistance and commitment. Also, we thank Sameh Wahba, Peter Ellis and Philip Karp at the World Bank Group, and Tatiana Gallego Lizon, Andres G. Blanco and Hyuna Lee at the Inter-American Development Bank for their commitment to building the partnership with KRIHS, and consequently offering insights that this book builds on. Last but not least, we are grateful to Routledge for accepting our proposal, extending particular thanks to Simon Bates, ShengBin Tan and Zixu Fan for handling all the hassles of publication with eagerness and passion.

Se Hoon Park Hyun Bang Shin Hyun Soo Kang 
$\because$ Taylor \& Francis Taylor \& Francis Group http://taylorandfrancis.com 


\title{
1 Introduction
}

\section{Reconsidering the Korean urban development experience for international cooperation}

\author{
Se Hoon Park, Hyun Bang Shin and \\ Hyun Soo Kang
}

This book builds on the collective efforts of the scholars and researchers who have studied the dynamics of urban development in the Republic of Korea (hereafter Korea) against the backdrop of increasing Korean Official Development Assistance (ODA) spending. The Korean government, armed with its developmental success, is now seeking an enhanced role in the world of international aid by building "the Korean model of ODA". In particular, the area of urban development has been playing an important role in this model-building effort, with Korea placing a special emphasis on the overseas infrastructure development market to boost its national economy. In this process, there appears to be a tendency to present the country's development experiences as a reference point for other countries in the Global South to emulate. Korea's condensed urbanization and industrialization, accompanied by the expansion of new cities and industrial complexes across the country, have become an attractive "model" to aspire to, even if the fruits of such development may not have been equitably shared across geographies and generations (Shin, Zhao and Koh, 2020).

Work for this book started in response to recent calls among some contributors to pay academic attention to current ODA programs in Korea, particularly those focused on the way urban development experiences are interpreted and formulated as a "model". So far, there has been a substantial body of literature on the Korean ODA based on its economic and social development experiences (see Kim and Kim, 2014a; Yi and Mkandawire, 2014). However, the urban dimension of the Korean ODA has not been sufficiently charted, despite the fact that the Korean government has placed an additional emphasis on "model-building" to market the country's urban development experiences in the Global South. Often, such experiences have been reinterpreted in a way that dissociates them from their historical, socioeconomic and political contexts, repackaging them in pursuit of the narrowly defined national interest. The size of Korean ODA spending on overseas urban development is already huge and is getting larger; however, academic reflections on what it means to learn from Korea have been lacking. Against this backdrop, the contributors to this book attempt to make critical reassessments of 


\section{Se Hoon Park et al.}

the Korean urban development experience while shedding light on the contextual understanding of such experiences. In this way, this book hopes to ensure that Korea's contributions to the international cooperation to build more equitable, resilient and sustainable urban futures occur in a manner that does not impose Korea's decontextualized version of urban development on other countries.

\section{Korea's unique position in international cooperation}

To some extent, Korea represents a rare "success" story for an ODA recipient, transforming itself from a poverty-stricken and war-torn country to the world's 11th largest economy within five decades. Korea graduated from an aid recipient country when it paid off its final structural adjustment loan to the World Bank in 1995, and was removed from the OECD's list of recipient nations in 2000. Korea had joined the group of international donor countries when it established the Economic Development Cooperation Fund (EDCF) to provide concessional loans in 1987 and launched the Korea International Cooperation Agency (KOICA) in 1991 to deal with grant aids. After joining the OECD in 1996 and the Development Assistance Committee (DAC) in 2010, Korea became an influential emerging donor in the world of international cooperation. In this regard, Korea occupies a unique position in the landscape of international cooperation.

In fact, even among emerging donors, Korea enjoys an idiosyncratic position. The literature on emerging and non-traditional donors has stressed that the aid they provide is grounded in different motivations from those of traditional donors (Mawdsley, Kim and Marcondes, 2017). Unlike traditional Western donors, who have been motivated by geopolitical and/or humanitarian interests, the emerging donors, led by China in particular, have been concerned more with the economic opportunities afforded by ODA. US aid to Afghanistan is considered to be motivated by geopolitical concerns, whereas China's aid to Nigeria is often regarded as being driven by China's economic interest in the oil market. The Korean ODA also shares a common feature with emerging donors in terms of its emphasis on the role of ODA for trade promotion. Moreover, like other emerging donors, Korea shows a low ODA/GNI (Gross National Income) ratio, a high percentage of concessional loans and tied aid, and a large number of recipients (Chun, Munyi and Lee, 2010). On the other hand, Korea exemplifies interesting differences from other emerging donors. Unlike other emerging donors, after joining the OECD/DAC, Korea has made a consistent effort to emulate traditional donors by constantly increasing the ODA/GNI ratio and by trying to conform to the norms and rules upheld by traditional donors (Kim, 2019). The OECD Development Co-operation Peer Reviews 2018 indicated that "Korea deserves praise" in its efforts to follow the recommendations of the Peer Reviews 2012 (OECD, 2018).

The ambivalent position of Korea in international aid is attributable to the nation's two different-and sometimes poorly coordinated-motivations within its ODA strategy, namely, the mercantilist interest and the diplomatic interest. On the one hand, in line with other emerging donors, Korea has placed a strong emphasis on "aid for trade" and has tried to utilize ODA as a tool for expanding 
business opportunities for Korean private firms abroad. This push has come mostly from the Ministry of Economy and Finance of Korea (MOEF)-responsible for the nation's economic affairs and budget distribution-through the use of ODA programs such as EDCF and KSP (Knowledge Sharing Program). On the other hand, the Ministry of Foreign Affairs (MOFA) and its implementation arm, KOICA, have a different policy priority, which is to enhance Korea's presence on the global diplomatic stage, often described as "middle power diplomacy" (Howe, 2015). This strategy involves finding a niche in the international aid market for Korea, which has fewer resources and less experience compared to its counterparts. All the efforts of the Korean government to follow the international norms given by the OECD/DAC and to take an active role in international cooperation-such as hosting Busan HLF-4 in 2011-seem to arise from this motivation.

These two different motives create a barrier to a more integrated and coordinated ODA policy, particularly the coordination between grant and loan programs. They are also a source of fragmented ODA programs in Korea where many agencies from central and local governments seek their own organizational interests in the ODA market (OECD, 2018). It should be noted, however, that the situation reflects the unique developmental position of Korea, which is situated between the advanced economies and the Global South. As an OECD member state, Korea seeks to increase its role on the international diplomatic stage by emulating the practices of traditional donors. However, at the same time, as a nation that is still catching up with the major advanced economies, Korea faces strong pressure, particularly from domestic politics, for its ODA to contribute to expanding economic opportunity.

\section{"Modeling" the Korean urban development experience}

Self-referencing is, perhaps, the most distinctive feature of the Korean ODA strategy. The Korean government seems to regard the nation's development experience as a valuable asset, particularly when it comes to its efforts to find a niche in the international aid world. A large part of Korea's ODA programs builds on its reputation as a development success.

It is often noted that Korea emphasizes the role of knowledge in development cooperation (Doucette and Müller, 2016). For instance, the KSP, which started in 2004 as a key ODA platform for Korea, is focused on knowledge sharing with the Global South. KSP particularly stresses the Korean experience of economic development, highlighting that "Korea's development experience contains practical solutions accumulated through trial and error, and its knowledge of successes and failures is a great asset for developing countries to help take on development challenges and promote sustainable growth" (KSP homepage, www.ksp. go.kr, last accessed March 30, 2020). KSP was launched by the MOEF and is implemented by three agencies, each one focusing on a different area of engagement: the Korea Development Institute (KDI) on socioeconomic development, the Export-Import Bank of Korea (EXIM Bank) on construction and infrastructure and the Korea Trade-Investment Promotion Agency (KOTRA) on trade and 
investment. All these are government organizations that have played pivotal roles in the course of Korea's economic development. At the time of writing, KSP has reportedly conducted 427 projects with 76 partner countries across the globe so far (ibid.) and has consolidated its role as an iconic program of the Korean ODA (see Potter, 2019 for a critical assessment of KSP).

Shortly after joining the OECD/DAC in 2010, the Korean government attempted to improve its ODA strategy based on its own development experience. In 2012, the Korean government released a report, the Korean Model of $O D A$ Strategy, in an effort to reorganize its development experience from an international cooperation perspective. The report pointed out that partner countries had allegedly been making strong demands for Korea to share its development experiences, which these countries would emulate Korea (The Korean Government, 2012). More importantly, however, the report emphasized that the Korean ODA should be more focused in terms of target areas and delivery processes in order to overcome the drawbacks caused by a lack of experience and the limited ODA budget. According to the report, the Korean ODA was to aim at "the sustainable development of partner countries, focusing on the demand and conditions of partner countries ... based on the comparative advantage of our development experience" (ibid., p. 16). In accordance with this aim, the report identified the key features of the Korean development experience and provided principles, strategies, and major programs tailor-made for diverse regions (ibid.).

One of the efforts to build "the Korean model" can be seen in the interpretation of the Saemaul (New Village) movement, which was a governmentinitiated rural development campaign in the 1960s and 1970s. This movement was quickly adopted as a flagship ODA program in 2016. KOICA and other state agencies have embarked on a worldwide campaign to disseminate Korea's rural development experiences under the banner of "Global Saemaul", which includes leadership training as well as other rural development practices (Jeong, 2017; Kim and Kang, 2015). The "Global Saemaul" strategy implies that this "model" can be applied in Global South countries regardless of their different social and economic backgrounds. The "Global Saemaul model" played a significant role in the recent history of Korean ODA under the previous government (2013-2017), which inherited a political legacy from the authoritarian regime (1961-1979) that organized the Saemaul Movement (Doucette and Müller, 2016).

In a similar vein, attempts to reproduce the "Korean model" can also be witnessed in the area of urban development, which has aimed at elevating the status of Korean urban development experiences to a pre-packaged commodity and a model that can be marketed to the Global South. Urban developmentincluding infrastructure investment-has special importance in Korea, not only because it has played a crucial role in Korea's economic and social development, but also because the country's overseas construction market accounts for a significant share of the national GDP (around 4-6 percent 2015-2018, www.index. go.kr). As such, urban development is crucial for sustaining the national economy. Against this backdrop, the model-building of the urban development experience 
for ODA has emerged alongside efforts to enhance business opportunities for the urban development sector in the overseas market (see Martin and Geglia, 2019).

One of the notable examples that epitomizes such practices is the ODA strategy to export the experience of new town construction under the banner of "city export" (see Chapter 9 in this volume by Yu-Min Joo). The phrase "city export" began to emerge in the mainstream media when Korean construction companies such as POSCO and GS Construction made an inroad into condominium complex development markets in Vietnam, Mongolia and Algeria in the mid-2000s, a process that has been dubbed the "Korean Wave in construction" (Munwha Daily, 2007). Soon afterwards, the concept entered into government discourses to become "the Korean model of urban development". The Ministry of Land, Infrastructure and Transport (MOLIT) and its affiliate Land Corporation were quick to use the "city export" concept to package their new city development projects, thus implanting "the Korean style of new city" in countries such as Kuwait and Azerbaijan (Meil Daily, 2009). The Seoul Metropolitan Government has also been active, under the slogan of "city export", to share its urban policy innovations - ranging from public transportation to e-government-with cities of the Global South. The recent smart city promotion of the Korean government is a new addition to this "city export" strategy (Han, 2019; Noh, 2019). ${ }^{1}$ Basically, while these are all public initiatives, they are obviously intended to boost overseas market shares for Korean private firms.

However, as pointed out by Chua (2011), efforts to export a country's development experiences as a "model" are problematic because it is inherently difficult, if not impossible, to crystalize "the model" from historical and place-specific development experiences. Korea is not an exception in this regard. As pointed out by critics (for example, Kim and Kim, 2014b; Igbafen, 2014), it would be naïve to describe the Korean development experience as a singular and uniform narrative. ${ }^{2}$ Korean development experiences can be differently interpreted depending on which timeframe one considers and which industrial sector or policy area one looks at. For instance, state policy toward the financial sector in the 1990s may be understood in a completely different way from that in the 1960s. The relation between the state and market in the manufacturing sector in the 1980s would have been different from the one in the social welfare sector during the same period. If one takes the political democratization of the late 1980s into consideration, one's interpretation of the Korean development experience would become even more complicated. Historical context, therefore, matters when it comes to transferring a country's development experiences elsewhere. In this regard, the aforementioned effort to export the rural development experience in the form of the "Global Saemaul model" can be said to have reduced the complex, multiscalar experiences of rural development to a set of technical issues of resource allocation or a simple question of how the government successfully cultivates the spirit of development (Doucette and Müller, 2016). The complexity of the Korean development experience has made it difficult to construct a so-called "Korean model" that can be simplified and thus transferred or exported to the Global South. 
We can see a similar difficulty in the Korean ODA strategy accompanying efforts to build "the Korean model of urban development", which is the focus of this book. In this model-building discourse, the model presents itself as a one-size-fits-all solution to recipient countries. It is hard to see what components from past urban development experiences would constitute the "Korean model" and how they can be applied to the divergent socio-cultural and politico-economic conditions in the Global South. The problematic role of the "Korean model" is further exacerbated by the fact that the government's and practitioner's arguments have mostly focused on how public actors can contribute to expanding the overseas construction market for Korean private firms. Consequently, norms of international cooperation-such as aid effectiveness and local ownership - are largely disregarded. As such, the currently circulated narrative of the "Korean urban model" may inevitably be narrow, simplistic and of less cultural sensitivity, thereby calling into question the viability of exporting the model itself.

\section{Interrogating the Korean urban development experience}

Even though Korea's urban development experience cannot be captured by a simple singular narrative, this does not mean that Korea's experiences have nothing to offer to the Global South. To some extent, it is hard to dispute that Korea's urban development during the past six decades has been a success story. Korea was a predominantly rural society in the early 1960s; however, after urbanizing and industrializing at a dazzling pace, it has become a highly urbanized and industrial country. At the beginning of the 1990s, more than 80 percent of the national population was living in urban areas, with living conditions and physical infrastructure (e.g., paved motorways, sanitation and communications) undergoing dramatic improvements. For example, the housing floor area per person expanded from $8.6 \mathrm{~m}^{2}$ to $31.7 \mathrm{~m}^{2}$ between 1970 and 2018 , despite an explosive increase in urban populations (see http://stat.molit.go.kr/). As far as the policy response to rapid urbanization is concerned, Korea is a clear benchmark for rapidly urbanizing countries.

How, then, should we understand the Korean urban development experience and its implications for international cooperation in our urbanizing global world? How can we go beyond the narrow and simplistic interpretation of the Korean experience and move forward to reinterpret it for the benefit of the global community in general? These are the key motivating questions that this book was designed to address. Contributors to this volume have been given the space to respond to these questions in ways that speak to their own research expertise. Before delving into individual chapters dealing with specific issues, we will outline the common ground shared by the contributors as entry points into further discussion.

First, we attempt to contextualize the Korean urban development experience. That is, we attempt to understand such experiences against the underlying conditions that shaped the adoption and implementation of particular 
policies. It has often been neglected in Korean ODA practices that there are important economic, social, political, and institutional conditions required for a particular policy to establish itself and start working. This is especially true when it comes to urban development, where the spotlight is more often placed on physical appearance, with the economic and institutional background that conditioned the production of the physical structure tending to be overlooked. For instance, Korea's new city development may look attractive to politicians and government officials in the Global South, and the urban strategy that led to it may appear simple and straightforward to transfer, when one only focuses on the construction work. What was important for the success of the policy of new city development, however, was that it was implemented under the specific politicoeconomic conditions of the 1980s and 1990s, which had high economic growth rates and an expanding middle class, as well as under particular institutional and legal arrangements according to which government, research institutes, public corporations, and private companies could work together, albeit with some friction (see Chapter 4 by Hyun Bang Shin and Chapter 12 by Se Hoon Park). Without understanding these specific contexts, efforts to transfer the new city development experience elsewhere will be wasted.

With regard to refocusing on the contexts of policies, two different dimensions can be identified. One is, of course, the context in which a particular urban policy was adopted and implemented, which may differ according to the different development stages of Korea. The country in the 1970s and 1980s was under the circumstance of the authoritarian state, weak civil society and high economic growth. Globally, Korea was situated in a "new international division of labor" and Cold War geopolitical tensions. All these elements, to varying degrees, influenced the development of Korea's urban policy and its implementation. It is also critical to understand the context of a country implementing lessons learned from the Korean experience. Many developing countries have a weak state, a fragmented society, high social inequality, a negative colonial legacy, low economic growth rates and are subject to the neoliberal world economic order. In addition, each country has unique social and economic conditions that are too diverse to be simplified, which limits the possibility of replicating certain development experiences (see also Chua, 2011; Shin, Zhao and Koh, 2020). In this regard, the current urban ODA in Korea is less sensitive to the diverse developmental contexts of the recipient nations, despite its emphasis on a demand-driven approach and local ownership.

Second, we intend to have a balanced view on the Korean urban development experience, recognizing both the positive and negative aspects of the government's interventions. The conventional approach in the Korean ODA mostly focuses on the bright side of Korean modern history while neglecting its darker side, such as spatial disparity and social inequality. As Howe (2015: 30) adeptly points out, the model claimed by the Korean government is a "sanitized" one. Even if we portray Korea's urban transformation as generally a success story, there is a less-spoken-about version of the story with a large area of hidden shadow. State-driven urban development was fast-paced and effective in terms 
of quantified achievements, but it was made possible in the context of a weak civil society and inadequate welfare system (Shin, 2018). As described by Won Bae Kim in this volume (Chapter 3), the regional disparity between the Seoul Metropolitan Region (SMR) and the rest of the country has been exacerbated over time due to the continuous concentration of people and businesses in the SMR. The massive housing redevelopment projects of the 1980s and 1990s caused large-scale forced evictions and displacement, consequently marginalizing vulnerable people (see Chapter 10 in this volume by Seong-Kyu Ha and Shin and Kim, 2016). The 2009 Yongsan Incident-which resulted in the tragic deaths of six people in the aftermath of a violent clash between police and resisting commercial tenants (Kim, 2009)-demonstrated that the negative legacy of urban transformation still looms large. It should be noted that the difficulties facing Korean cities at the moment mostly result from those conditions that made it possible for the nation to develop in previous decades.

Third, we try to go beyond the conventional technology-oriented and businessinterested approach, by reinterpreting urban development as social institutions embedded in society. In the Korean ODA, urban development has been predominantly viewed as nothing more than engineering and/or infrastructure projects. This reductionist interpretation prevails not only among government officials, but also among many academics in Korea. It is suggestive that the ODA program by MOLIT has been designed and managed by the Overseas Construction Policy Division as part of the ministry's promotional activity for the overseas construction market (Park et al., 2019). Furthermore, the smart city promotion, actively supported by the incumbent government, has focused mostly on technological improvement and infrastructure development, neglecting all other social, economic and political impacts on urban environments. One important problem in the technology-oriented interpretation of the Korean experience is that it cannot provide any normative value for international cooperation. Perhaps this approach could help persuade domestic taxpayers in the short run; however, this cannot be the best way to take advantage of the Korean development experience to strengthen the nation's position in international cooperation.

Since the adoption of the 2030 agenda by the United Nations in 2015, the international community has underscored the normative values in urban development by adopting the concepts of inclusive, resilient and sustainable cities. In addition, the concept of "the right to the city" has come to the forefront of discussions among international organizations such as the UN Habitat and Cities Alliance; this concept is said to represent an alternative view of an increasingly polarized global urban society (Parnell, 2016). These international norms were further developed by the UN Habitat when the New Urban Agenda was adopted as a guiding principle for the international community in Quito, Ecuador in 2016 (UN Habitat, 2016). However, these norms have not been adequately discussed and adopted by the urban ODA in Korea. Korea's urban development experience could perhaps be interrogated in line with this international movement, thereby allowing Korea to stake out a better role in the international community as a critical source of inspiration for rapidly urbanizing countries. 


\section{Structure of this book}

This book is organized into three parts. In Part I, we outline the urban transformations in Korea since the 1960s and their implications for international cooperation to attain sustainable urban development. Mike Douglass (Chapter 2) offers a comprehensive overview of the Korean urban and regional development, focusing on major policy shifts that are closely associated with the changing configurations of the relationships between the government, civil society and the corporate economy. While acknowledging Korea's success in achieving a degree of national prosperity, Douglass also reminds us of the struggles and inequities that called for changes in governance at urban as well as national scales. Won Bae Kim (Chapter 3) examines the main concerns and elements of regional policy in Korea over the past six decades, highlighting the two major concerns of regional disparity and regional competitiveness. In doing so, he draws implications from Korean regional policy for international development cooperation. Hyun Bang Shin (Chapter 4) asserts that Korea's property-based urban transformation was pursued by the developmental state in its effort to nurture the growth of (real estate) capital and middle classes and that the property hegemony-based model of urban (re-)development is effectively a rent gap-based revenue-sharing model, which widens asset inequality and leaves little room for non-financial contributors. He calls for a careful treatment of the country's urban development experiences before exporting such a model of city-making to urbanizing societies elsewhere. Blaž Križnik and Su Kim (Chapter 5) offer an insight into the role of community and neighborhood in urban transformation in Korea, which is a rarely charted area in the existing literature. While highlighting the dynamics of state-community relations in the process of urban development, they claim that the state facilitated the commodification of localities through property-led urban redevelopment while, at the same time, localities challenged the state and struggled against the commodification of localities.

In Part II, we attempt to critically reassess the modeling of the Korean urban development experience and its implications for other countries from an international comparative perspective. Jamie Doucette and Farwa Sial (Chapter 6) argue that the self-referential model-building of Korea's knowledge-sharing initiatives risks replicating national state-centrism, a view that is often invoked in celebratory narratives of Korea's rapid economic development. Cuz Potter and Jinhee Park (Chapter 7) emphasize the limitations of a singular model for envisaging Korean urban development. By taking the example of a condominium complex construction project in Vietnam, they propose that "a multitude of models" is inevitable. Hyung Min Kim, Julie Miao and Nicholas Phelps (Chapter 8) identify the relative position of Korea amid the recent emerging urban development leadership in East Asia. By comparing the three urban development models of Korea, China, and Singapore, they shed light on how each model may reflect the national development path as well as the national interest.

In Part III, we explore individual policies and institutions, focusing on how these policies and institutions were established and practiced in Korea 
and what these experiences might mean for international cooperation. YuMin Joo (Chapter 9), by examining how the so-called "city export" discourse was formulated and developed in Korea, sheds light on the rarely told dimension of the Korean model, that is, the public value of urban development for international cooperation. Seong-Kyu Ha (Chapter 10) reviews the housing and urban redevelopment policies of Korea from the "housing right" perspective. He claims that the overall quality of housing in Korea has improved considerably since the 1980 s but that, at the same time, urban redevelopment projects have further marginalized vulnerable groups, thereby eventually generating the polarization of housing conditions in Korea. Seowhan Lim (Chapter 11) explores the land development scheme in Korea, which has played a pivotal role in facilitating rapid urban transformations. Detailing the structure and features of Korea's land development scheme, he stresses the background conditions that enabled it to be designed and implemented in a society under authoritarian rule and speculative land demand. Se Hoon Park (Chapter 12) sheds light on public research institutions as an integral part of Korea's national developmental system. He examines why and how policy research institutes in Korea have played such a pivotal role in public policy development with special focus on three elements: the knowledge production market, government-institute relations and the urban development regime. Last but not least, Jieun Kim (Chapter 13) deals with public development corporations as an engine of development and as part of Korea's urban development model. She illustrates how public development corporations became pillars of the urban development model, how their roles are changing as Korea's economic growth and urbanization slow down and what implications they offer to the Global South.

In conclusion, this book was planned according to the simple assumption that not all countries in the Global South have the potential to follow the same developmental path that Korea took in the 1960s and 1970s. Korea's development experience, no matter how remarkable it is, is just one example, specific in time and place. One may certainly draw lessons from it. However, at the same time, the experience of Korea must be critically reflected upon and the lessons drawn from it modified by other countries facing different developmental contexts. These modifications require a more nuanced understanding of the relevant policies than we have seen in current ODA practices. In this regard, we hope that this book opens discussion about, rather than offers hasty answers to, our question of how the Korean urban development experience should be reinterpreted and what it can contribute to rapidly urbanizing countries to allow them to be more inclusive, resilient, and sustainable.

\section{Notes}

1 See the presentations in the forum organized by KOTRA and the Seoul Metropolitan Government on July 4, 2019 in Seoul (Han, 2019; Noh, 2019). This forum was designed to discuss future policy directions for supporting the so-called "city export" 
with participation from the Seoul Metropolitan Government, LH Corporation, private engineering companies, and related experts.

2 Similar limitations can be witnessed among "developmental statist" theorists, who have highlighted the importance of state power and state autonomy in explaining the economic development of Korea (see Amsden, 1989; Woo-Cumings, 1999). Such explanations are not sufficient to tell the story of the Korean state because they focus too much on the efficiency of governance and the centralized operation of government functions, thus incurring the shortfalls of "methodological nationalism" and "methodological statism" (Doucette and Park, 2018).

\section{References}

Amsden, A. H. (1989). Asia's Next Giant: South Korea and Late Industrialization. New York: Oxford University Press.

Chua, B. H. (2011). "Singapore as Model: Planning Innovations, Knowledge Experts," in R., Ananya and A. Ong (eds.), Worlding Cities: Asian Experiments and the Art of Being Global. Chichester: Wiley-Blackwell, pp. 27-54.

Chun, H.-M., E. N. Munyi, and H. Lee (2010). "South Korea as an Emerging Donor: Challenges and Changes on its Entering OECD/DAC," Journal of International Development 22(6), pp. 788-802.

Doucette, J. and A. R. Müller (2016). "Exporting the Saemaul Spirit: South Korea's Knowledge-Sharing Program and the 'Rendering Technical' of Korean Development," Geoforum 75, pp. 29-39.

Doucette, J. and B.-G. Park, eds. (2018). Developmentalist Cities? Interrogating Urban Developmentalism in East Asia. Leiden: Brill.

Han, M. H. (2019). "Achievement and Task for the Korean Urban Model," in the forum for Achievement and Task for the Korean Urban Model on July 4, 2019 in Seoul (in Korean).

Howe, B. (2015). "Development Effectiveness: Charting South Korea's Role and Contribution," in I. Bradford, S. Snyder, C. I. Bradford, T. Dalton, B. Howe, J. K. O'Donnell and A. O'Neil (eds.), Middle-Power Korea: Contributions to the Global Agenda. New York: Council on Foreign Relations Press, pp. 21-43.

Igbafen, M. L. (2014). "South Korea's Development Experience as an Aid Recipient: Lessons for Sub-Saharan Africa," in E. M. Kim and P. H. Kim (eds.), The South Korean Development Experience: Beyond Aid. New York: Palgrave Macmillan, pp. 111-135.

Jeong, H. (2017). "Globalizing a Rural Past: The Conjunction of International Development Aid and South Korea's Dictatorial Legacy," Greforum 86, pp. 160-168.

Kim, E. M. and P. H. Kim, eds. (2014a). The South Korean Development Experience: Beyond Aid. New York: Palgrave Macmillan.

Kim, E. M. and P. H. Kim (2014b). "From Development to Development Cooperation: Foreign Aid, Country Ownership, and the Developmental State in South Korea," in E. M. Kim and P. H. Kim (eds.), The South Korean Development Experience: Beyond Aid. New York: Palgrave Macmillan.

Kim, K.-T. (2009). "Six Dead as Police Crash with Protesters in Seoul." Independent, January 20, 2009. Available at: (www.independent.co.uk/news/world/asia/six-deadas-police-clash-with-protesters-in-seoul-1451650.html) [Accessed August 28, 2020].

Kim, S. (2019). "The Misadventure of Korea Aid: Developmental Soft Power and the Troubling Motives of an Emerging Donor," Third World Quarterly 40(11), pp. 2052-2070. 


\section{Se Hoon Park et al.}

Kim, S. and H. Kang (2015). "Young and Dynamic? The Curious Case of Korea's National Level Post-2015 Process," Journal of International Development 27, pp. 776-800.

The Korean Government (2012). Implementation Strategy for Korean ODA Model. www.korea.kr/archive/expDocView.do?docId=32621 [Accessed August 28, 2020] (in Korean).

Martin, B. and B. Geglia (2019). "Korean Tigers in Honduras: Urban Economic Zones as Spatial Ideology in International Policy Transfer Networks," Political Geography 74. doi: 10.1016/j.polgeo.2019.102041

Mawdsley, E., S. M. Kim and D. Marcondes (2017). "Political Leadership and 'Nontraditional' Development Cooperation," Third World Quarterly38(10), pp. 2171-2186.

Meil Daily (2009). "Korean Style of New City as a Popular Product in Global Market." August 10 (in Korean).

Munhwha Daily (2007). "Rush to the Export of the Korean Style New City." January 30 (in Korean).

Noh, E. H. (2019). "Cases of Public-Private Cooperative Overseas Business of Seoul's Policy Model," in the forum for Achievement and Task for the Korean Urban Model on July 4, 2019 in Seoul (in Korean).

OECD (2018). OECD Development Co-operation Peer Reviews: Korea 2018. Paris: OECD.

Park, S. H., B. J. Lee, Y. An, H. You, E. Lee, K. S. Kwon, Y. S. Kim (2019). Policy Directions of International Development Cooperation in the Urban Sector for Implementing SDGs. Sejong: Korean Research Institute for Human Settlement (in Korean).

Parnell, S. (2016). "Defining a Global Urban Development Agenda." World Development 78, February 2016, pp. 529-540.

Potter, C. (2019). "Just Like Korea in the 1970s? Policy Transfer and the Fiction of Familiarity," International Development and Cooperation Review 11(4), pp. 21-36. doi:10.32580/idcr.2019.11.4.21.

Shin, H. B. (2018). "Urban Movements and the Genealogy of Urban Rights Discourses: The Case of Urban Protesters against Redevelopment and Displacement in Seoul, South Korea," Annals of the American Association of Geographers 108(2), pp. 356-369.

Shin, H. B. and S.-H. Kim (2016). "The Developmental State, Speculative Urbanisation and the Politics of Displacement in Gentrifying Seoul," Urban Studies 53(3), pp. 540-559.

Shin, H. B., Y. Zhao and S. Y. Koh (2020). "Whither Progressive Urban Futures? Critical Reflections on the Politics of Temporality in Asia," CITY. doi: 10.1080/ 13604813.2020 .1739925

UN Habitat (2016). "New Urban Agenda: Quito Declaration on Sustainable Cities and Human Settlements for All" (http://habitat3.org/the-new-urban-agenda/) [Accessed August 28, 2020].

Woo-Cumings, M., ed. (1999). The Developmental State. Ithaca, NY: Cornell University Press.

Yi, I. and T. Mkandawire (2014). Learning from the South Korean Developmental Success: Effective Developmental Cooperation and Synergistic Institutions and Policies. London: Palgrave Macmillan. 


\section{Part I}

Outlining the urban transformation of Korea 
$\because$ Taylor \& Francis Taylor \& Francis Group http://taylorandfrancis.com 


\title{
2 Transformations in the governance of urban and regional planning in Korea
}

\author{
From (neo-)developmentalism to \\ civic democracy, 1965-2020
}

\author{
Mike Douglass
}

\section{Introduction}

Within two decades of being listed among the lowest income countries in the world, South Korea in the late 1960s was being heralded as a "miracle economy". The accelerated urban transition from 20 percent of the population in 1955 to more than 80 percent urban in 2000 was of fundamental importance to the country's rapid economic and social improvements. Although an uneven process that has encountered junctures of deep political and economic crises, the shift from an agrarian to an urban-industrial society has provided the foundations for substantial improvements in income and general welfare (OECD, 2019).

These advances were not gained by adherence to a static model of governance. Over several decades Korea ${ }^{1}$ experienced fundamental transformations in modes of governance. The deeply contextual dynamics of these shifts underscore the understanding that they were neither preordained passages through stages of development nor a linear road toward democracy. Rather, they were outcomes of changing relations of power among the state, civil society and corporate economic interests within and beyond the country. Figure 2.1 summarizes these transformative dynamics that underlie urban and regional policies from 1965 to the present. They can be characterized by, first, the emergence of the developmental state. Second was the transition into neo-developmental mode of statecorporate partnerships beginning from the 1980s that coincided with political reform toward democratic governance. Third, along with democratization came the devolution of state authority to local levels of governance, which gave rise in the early 21 st century to city regions as potential loci of participatory civic democracy.

\section{The developmental state in spatial planning, 1960s-1980s}

The inauguration of the Park Chung-hee Government (1963-1979) initiated Korea's rapid urban-industrial transformation. In leading this drive, the national 


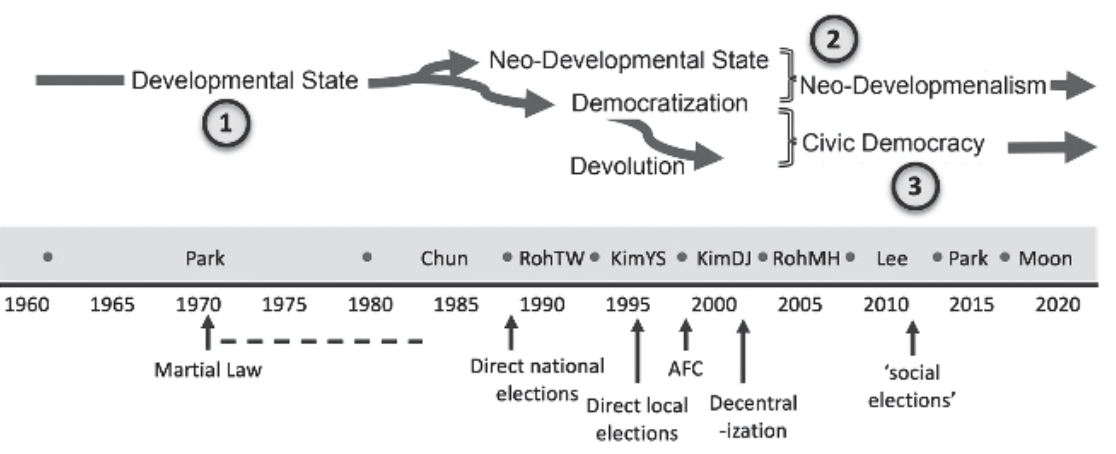

Figure 2.1 The political dynamics of urban and regional policy in Korea, 1960-2020.

government took on extraordinary powers that have been summarized as the "developmental state", loosely defined as a strong, highly autonomous state acting as the "big push" in industrialization (Douglass, 1994; Evans, 1995). Among the most important sources of state autonomy under Park's government were:

- Inherited political culture accepting a strong state (Im, 1987).

- Radical agrarian land reform that occurred following the Korean War (19501953), effectively eliminating rural elites who could have substantially weakened state autonomy from elite and class interests.

- Nationalization of the banking system, allowing government to autonomously invest in spatial planning and industrial capacity while also building a highly trained techno-bureaucracy to inform and implement policies ( $\mathrm{Ha}$ and Kang, 2011). This further provided the means for government to channel people's savings into creating the chaebol from small family-owned enterprises to become among the largest corporations in the world.

- Continuing state of war conditions with North Korea and anti-communism that were used to justify martial law and state suppression of civil society and labor movements.

- US military aid adding financial resources to the Korean government (Kim, 2017).

State autonomy is not absolute; it is necessarily imbedded in social networks (Evans, 1995). In addition to a bureaucracy of skilled, merit-based recruits, the Park regime drew together a "leader-dependent" tier of personnel selected from his home region and school ties in the southeast who received special treatment in promotions from Park. This favoritism would echo through Korean politics and spatial policies for decades to come (Ha and Kang, 2011).

With the invocation of martial law in 1972, which effectively lasted until 1987, competitive elections were abolished, labor union actions were severely restricted and basic human rights were not guaranteed. With the foundation for economic 
growth based on maintaining a low-wage labor force and a compliant civil society, while improvements in standard of living were widespread, they also favored elites in government and the rising chaebol. Technical rationality and social stability in the face of the communist north were used to depoliticize social issues and justify harsh responses to social protests, which became chronic in urbanizing Korea. As underscored by Im (1987), Korea's bureaucratic authoritarianism did not create the country's strong state; rather, it helped change a society with a long-held political philosophy supporting a strong state into a developmental state. It also generated militant labor unions that would figure prominently in political reform over the coming decades (Minns, 2001).

For Korea and other "newly industrializing economies" (NIEs) of East Asia (Taiwan, Hong Kong and Singapore), the turn toward export-oriented manufacturing was historically opportune. It occurred at a critical global juncture marked by the appearance of a "new international division of labor" (NIDL) that entailed the massive deindustrialization of high-income economies of the West accompanied by the redeployment of labor-intensive sectors of manufacturing to selected lower-income countries (Froebel, Jürgen and Otto, 1980). With most potential candidate countries still deeply entrenched in import-substitution strategies, nationalization of foreign invested companies and non-alignment rejection of re-integration with former colonial masters, competition was exceptionally limited for the new wave of global investment in export-oriented manufacturing searching for sites outside of the high-income countries of the world (Elkins, Guzman and Beth, 2006). ${ }^{2}$

The Asian NIEs were nonetheless competing against each other, and Korea's developmental state was able to keep wages lower than those in the other Asian NIE competitors (Minns, 2001). They also had to compete by having a developmental state with the political will to reliably develop, plan and institute policies, including those related to the built environment for industrialization. The commitment to bureaucratic meritocracy, including the establishment of independent and highly capable policy think tanks, also required political will that is not ubiquitous. While no country is free from corruption, in Korea roads and bridges were nonetheless built, and policies were implemented. These are the hallmarks of the developmental state that have been contrasted with the "soft state" dominated by rent-seeking elites (Myrdal, 1970; Evans, 1989).

In this light, a common feature shared by the Asian NIEs was that the state, and not the market, stood at the helm of the space-economy of planning and development. However, variations among the four Asian NIEs were substantial. Whereas Singapore and Hong Kong used public housing as their tool to discipline society, Korea (and Taiwan) used police powers. Hong Kong had a free press; Korea tightly controlled the press. In creating the chaebol through state support, Korea stood alone among the NIEs in not relying on FDI for its endogenous export industrialization. The main point to be made is that no single model of a developmental state existed; each was a particular mode reflecting specific contexts and opportunities appearing during its time (Douglass, 1994). 


\section{Mike Douglass}

Spatial planning was a crucial component of Korea's developmental state. In addition to providing critically needed infrastructure for industrialization, it was used to try to stop the growth of Seoul; its effectiveness was, however, quite limited. From 1953 to 1965 Seoul doubled in population from approximately 1 million to 2 million residents. When export-oriented manufacturing took off in the late 1960s, migration to Seoul greatly accelerated. By 1990 the city had reached 9 million in population, and thereafter expanded into neighboring Gyeonggi-do and Incheon to form the extended Capital Region (CR). By the year 2000 this mega-urban region had a population in excess of 25 million, or nearly one-half of the total population of the country.

The attraction of Seoul was multifaceted, including higher social status, employment, quality of education and altogether higher life chances than anywhere else in the country. ${ }^{3}$ However, the unstoppable speed of Korea's spatial polarization also generated a number of social problems. In particular, the housing situation worsened as the ratio of housing stock to number of households reached 54 percent in 1980. Slums were prevalent. Air pollution in Seoul also became a serious health threat.

In response to the undesired outcomes of the rapid growth of Seoul, the First Comprehensive National Physical Development Plan (1972-1981) adopted four types of policies to inhibit and organize the growth of the capital city:

- Direct controls on population mobility

- Forced elimination of squatter settlements in Seoul (from 1960s);

- Special citizens tax on Seoul residents (1973);

- Severe restriction on the expansion of universities (from 1970s).

- Direct controls on industrial expansion

- Penalty tax for factory construction (1973);

- Restricting new construction of industrial plants in Seoul (1975);

- Compulsory relocation of industries away from Seoul.

- Containment of urban expansion

- Adoption of green belt zones around Seoul and all major cities (1972);

- New towns to spatially organize the capital city (1967-1986).

- Plans to remove of government functions from Seoul (1972).

To attract development away from Seoul, the government called upon the widely adopted "growth pole" strategy of concentrated decentralization to disperse industrial growth to selected provincial locations. Industrial parks, free trade zones and massive investment in new heavy industry sites such as Ulsan and Pohang were all constructed. Busan, the second largest city and southeast gateway port to the Pacific, took on the role of light manufacturing. Daegu became a textiles and apparel center.

Outside of Seoul particular attention was given to southeast Korea, the home provinces of President Park's and other political leaders. An expressway was constructed between Seoul and Busan. A number of new towns were also built in this region. This led to a bipolar development pattern anchored on each end 

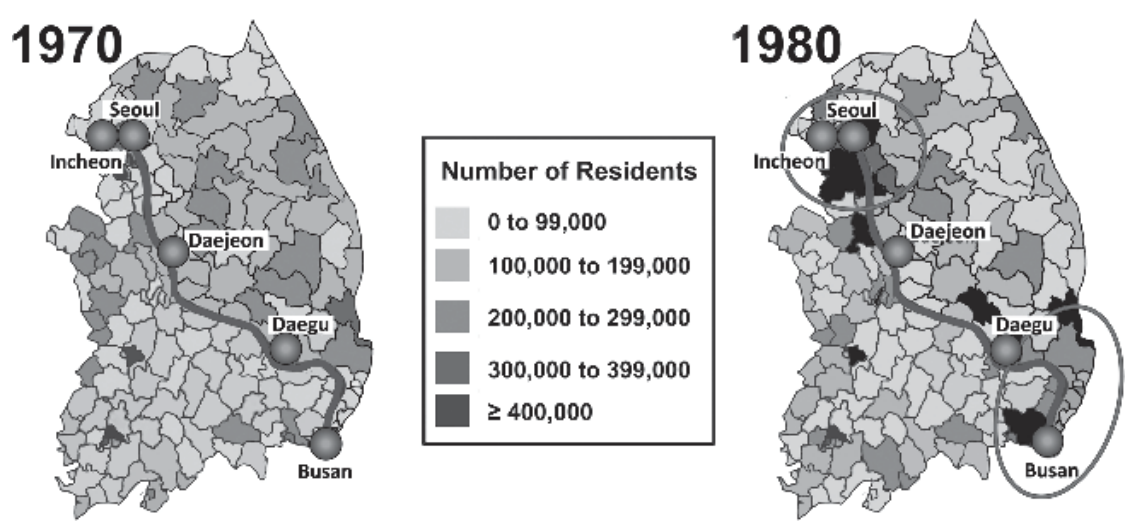

Figure 2.2 National development corridor, 2011.

by Seoul and Busan (Figure 2.2). Korea's gateway to the world economy was more naturally through the southeast, and Seoul's precarious location near the border of an aggressive communist state contributed to the felt need to move development away from the capital city. Yet despite these conditions favoring the southeast and all of the spatial planning efforts aimed at attenuating national spatial polarization in the $\mathrm{CR}$, its share of the national population rose from 29 to 47 percent between 1970 and 2000 .

The government also launched a national village modernization program, the Saemaul Undong (New Village Movement), along with a green revolution program in the 1970s. Village modernization was a centrally orchestrated selfhelp program focusing on tile roofs, local roads and other village infrastructure such as water wells and electricity. The green revolution served to momentarily move the country toward self-sufficiency in grain production for national food security, cheap food for rapidly increasing urban populations and to lessen foreign exchange losses.

The Saemaul Undong was successful in raising rural incomes to near urban levels - a rare accomplishment that set Korea apart from other Asian countries. However, the program declined rapidly by the end of the 1970s. Village self-help reached its limits, crop infestations resulting from reliance on a single variety of high-yielding rice, the high level of subsidies needed for farmers and urban consumers and the assassination of its creator, President Park, all contributed to its demise (Douglass, 2014).

The strategy and fate of the Saemaul Undong point toward a major missing element in Korea's spatial planning: rural-urban linkages. The idea that rural and urban development could mutually benefit or that towns can make positive contributions to rural development was overlooked due, in part, to the separation of urban from rural (agriculture) planning bureaucracies and the growth pole strategy view of rural areas merely as sources of cheap surplus labor. Whether a 
rural-urban linkage strategy would have advanced rural regional development in Korea is a matter of conjecture, although achievements were made in other countries (Tacoli, 2006). The longer-term outcomes of this neglect were missed opportunities to stem rural depopulation as well as shrinkage of rural towns that would become increasingly pronounced in the coming decades.

All of the particular circumstances of Korea's miracle economy under its developmental state disallow putting it forward as a model for other countries to mimic. The deeply contextual conditions for such elements of state autonomy as radical agrarian land reform and nationalization of financial institutions are not viable policy options in most settings today. Even in Korea by the mid-1980s changing internal and global conditions brought to a close this first round of Korea's rise to a high-income society under a developmental state-just two decades after it appeared. Success of political reforms toward democratic governance, the rise of the chaebol to transnational corporate levels and the permeating spread of global neoliberalism combined to transition Korea into a neo-developmental era.

\section{Neo-developmentalism and democratization 1990s-present}

\section{Neo-developmentalism}

In the wake of the demise of the authoritarian developmental state, two strands of spatial planning emerged in Korea in the late 1980s: neo-developmental projects designed and implemented from above by government through private corporate sector partnerships with overtures to democratic reforms, and devolved participatory forms of local governance.

The turn toward neo-developmentalism began in the 1980s from within Korea and from changing global dynamics. The source from within was the growing power of Korea's chaebol, which by 2011 saw just ten of these family-owned conglomerates accounting for nearly 80 percent of Korea's GDP. The second source was the ascent of global neoliberalism that worked through external pressures on the Korean government to liberalize Korea's financial institutions, privatize government institutions and services and open the economy to foreign investment. Yet instead of the government taking a passive role that was common elsewhere in Asia through neoliberal policy shifts, the Korean government continued to play a strong role in promulgating development policies with corporate partnerships.

The result of these changing power relations is an amalgamated "neodevelopmental" mode of policymaking in which government and corporate interests co-lead project design and implementation (Park, Richard and Asato, 2012). Top-down command planning with no or only token citizen participation; mega-scale projects; supply rather than demand-driven spatial policies; wholesale changes in land use and the natural environment; orientations toward physical techno-fix planning solutions for social problems; and standardized replication of projects are all characteristics of neo-developmentalism (Ha and Lee, 2007). New towns with mass-produced housing, industrial estates, free economic 
zones, global city projects such as the "second miracle on the Han" (Kim, 2008), smart cities cum eco-cities and u-towns (ubiquitous-towns, meaning they are suitable for all cities across the globe) and consolidated mega-regions are among the many types of neo-developmental projects. City marketing, place-branding, high security, gated and fortified buildings and "Central Park" simulacra can be added to their characteristics.

The construction of housing and new towns is emblematic of neodevelopmentalism. A major impetus to the housing and new town construction surge in the late 1980s was the 1989-1993 "2 Million Housing Project", which substantially filled the long-standing void in housing in the CR. The escalation in housing construction was quickly routinized by government and chaebol land developers to spread across the nation. As a result, less than 10 percent of housing in most of the CR was built before 1979 (Park et al., 2016). Single-family detached houses fell from nearly 90 percent in 1980 to about one-quarter over the next three decades, thus earning Seoul the title of "apartment city", erasing Korea's vernacular architectural history and socially functioning neighborhoods.

New towns also began to be deployed to regions outside of Seoul CR in response to the decline of local economies resulting from the pervasive relocation of Korea's labor-intensive manufacturing to lower-wage economies in Asia. In evidence of the fundamental freeing of the chaebol from its previous national territorial constraints, government-assisted FDI from Korea's chaebol exploded from a level of US\$57 million in 1981 to over US\$20 billion by 2007 . This trend was further accelerated by the Asia Finance Crisis in 1997, which also relieved the chaebol from such previous obligations as full-time employment of Korean labor (Lee, Lee and Park, 2012).

At the level of strategic spatial planning, solutions to rising spatial disparities resulting from deindustrialization were sought through the pursuit of the goal of regional balance with a focus on linking local revitalization with large-scale new town construction. The target of regional balance strategies in Korea has not been about uneven spatial development in general, but rather centrally about curtailing the expansion of the CR. As with policies under the developmental state, this concern has had three main components: (1) stopping the growth of the CR, (2) spatially organizing the settlement of the outer areas of the CR, mostly through new town construction and (3) stimulating the growth of cities and regions outside of the CR through, for example, industrial growth poles, free trade zones, new towns and housing and, more recently, regional revitalization strategies aimed at enhancing local government capabilities to plan and finance project.

Among the most prominent of recent regional balance attempts is Sejong City, a newly built national administrative capital for the relocation of government functions away from Seoul. First proposed by President Roh Moo-hyun in 2003, it was launched in 2012 as Sejong Special Autonomous City. Slated for completion by 2030 at a projected cost of over US\$20 billion, it is a quintessential neo-development master-planned project that leveled an existing hilly landscape for a completely new $465 \mathrm{~km}^{2}$ automobile-oriented smart/eco-city. Its target 


\section{Mike Douglass}

population of 500,000 will be the equivalent of about 2 percent of the population of the CR.

In recent decades new towns have been given new clothing aimed at catching the global promotion of smart techno-cities. One mode is "u(biquitous)-towns", which is a term used to signify fully digitally wired cities (Lee et al., 2008). Because of their infrastructure requirements, they "will be realized mainly in newly built cities (because) it's easier to start from a white blank canvas" (Hwang, 2005: 1). The great majority of u-town and other new town projects are located in the CR, including Songdo, a flagging $\$ 40$ billion new city in Incheon.

By the early 2000s the unrelenting production of housing encountered the well-known problem of supply-driven production, namely, the inability to anticipate actual demand. As a result, uninhabited apartments in 2015 in Korea totaled 570,000 , which was an increase of 200,000 from 2010 exacerbated by decreasing depopulation outside of the CR (Kim, 2016) (Figure 2.3). In the CR, however, housing supply has continued to fall short of effective demand due to both supply and housing cost issues, which is also related to speculative investment by more affluent property owners.

Attempts were also made to use industrial estates to improve regional balances. While those constructed after 1990 show a greater dispersion away from the CR (Figure 2.4), they have remained largely unintegrated into local

1995-2000

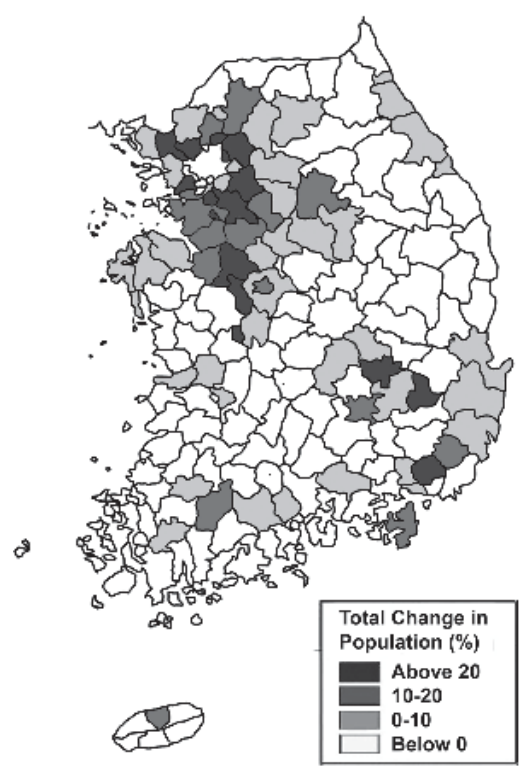

2000-2005

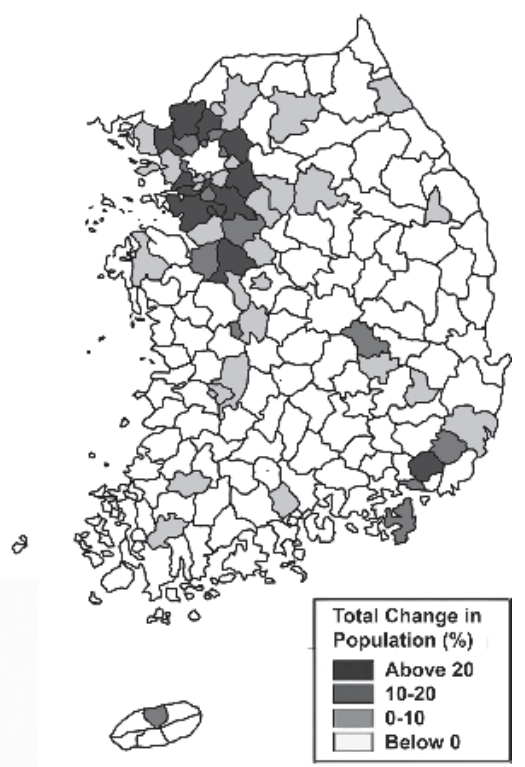

Figure 2.3 Population growth by county, Korea 1995-2000 and 2000-2005. 


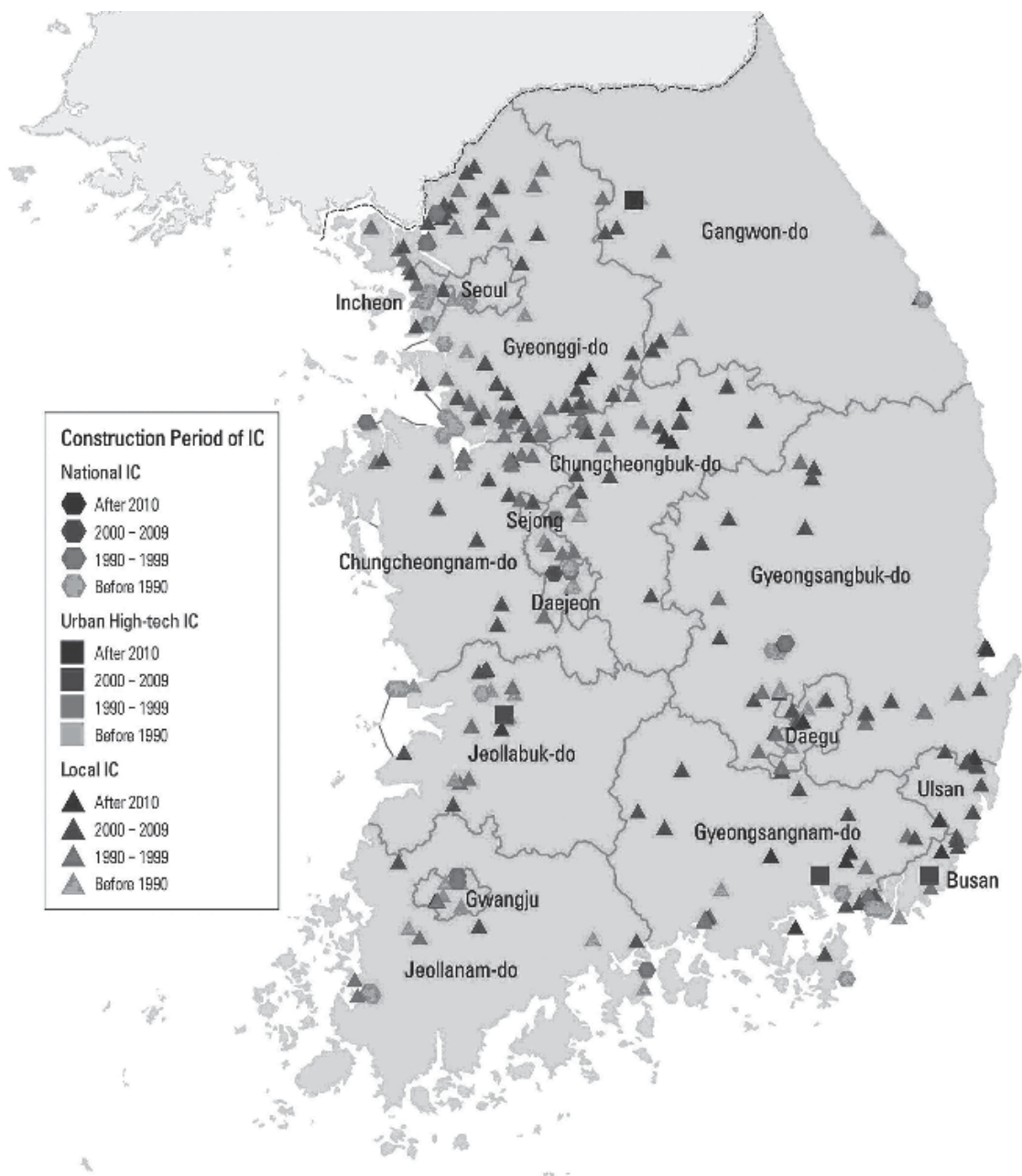

Figure 2.4 Spatial distribution of industrial complexes before 1990 to after 2010.

economies, and have not yet made a significant contribution to them. Similarly, the FEZs in the CR have been much more successful than those elsewhere (KDI, 2015). At the same time, in Korea's post-industrial economy the CR has not only become increasingly important in higher-technology industries, it has also expanded in employment serving chaebol global headquarter functions. From 1966-1995, more than four-fifths (84 percent) of the total increases in manufacturing employment accrued to the CR and the southeast (Kim, 2000). Industrial estates elsewhere have experienced high vacancy rates accompanied by low levels of inter-firm linkages and an absence of R\&D capabilities. 


\section{Mike Douglass}

Particularly hard hit by steep population losses, rural regions have been included in programs aimed at overcoming spatial imbalances. In 1995, the government slated 33 cities and 32 counties for amalgamation to become "Shi-Kun" (urban-rural) Consolidated Cities (KRIHS, 1994). The purpose was to incorporate economically depressed areas with neighboring cities to allow for greater efficiencies in extending basic infrastructure while strengthening local economic potential. Similarly, from 2000 rural revitalization programs were launched for 163 basic living areas based on volunteerism and cooperation. These programs reportedly did not make headway due to local government not having yet become "a sound and energetic system" (LHI, 2014). More to the point, Korea's rural depopulation and lack of well-developed town-based rural support functions have passed a tipping point at which possibilities for revitalization are chronically slipping away. This is evidenced by stark data showing that between 1982-2010 the government closed more than 5,000 rural schools due to insufficient student numbers (Chandler, 2010).

\section{Democratization and neo-developmentalism}

As democracy ascended from 1987 onward, neo-developmental spatial strategies began making overtures to participatory governance that incorporated social as well as economic objectives. For example, heavily subsidized free economic zones and industrial clusters were pursued at the same time that localities were encouraged to undertake their own urban revitalization programs. Some of these ideas were continued across presidential elections. Others were discarded. Park Gyeun-hye's presidency exemplified a conservative with a populist front as she promoted the "Happy Living Zone" initiative focused on quality of life and neighborhood regeneration programs aimed at revitalizing old city centers with a promise to cut back new town construction. Her "demand-driven customized assistance" acknowledged the criticism of supply-driven neo-developmental projects. At the same time, she supported such neo-developmental plans as the Pangyo Creative Economy Valley (Kim and Lim, 2016). Similarly, while the Moon Presidency brought democratization to a new level as he put forth his agenda to accelerate political and financial decentralization and reinforce balanced development, he also stressed local competitiveness, innovative cities and industrial parks that represent a straight line continuation of neo-developmental approaches to regional development.

In sum, despite the many policy initiatives to link central planning with local initiatives, neo-developmentalism in practice has remained substantially unconverted at national levels of planning. This observation can be seen when viewing the kinds of policies that have consistently been carried on by each president, and those that have not. Those that have continued through time regardless of the change of presidency include new towns, housing production eliminating middle- and lower-class neighborhoods, free trade and export zones and corporate megaprojects such as super-tall buildings, vast shopping malls and global gambling resorts. For example, in 1998 in the wake of the Asia Finance Crisis, the 
government announced its intentions to establish a number of free trade zones to attract global investment (Cha, 1998; Korea Times, 2010). By 2019, eight such zones were in place around the country (KFEZ, 2019). Yet an initiative to enhance regional cooperation and collaboration was abandoned when the presidency was passed to Park Gyeun-hye.

Some observers have suggested that neo-developmental and participatory planning each have a role to play in spatial planning. This position is problematic for three reasons. First, the opportunity costs and actual public expenditures on neo-developmental projects are immense and have taken resources away from locally engaged participatory forms of planning. Second, neo-developmentalism spatially collides with and has destroyed or undermined existing settlements, livelihoods and the environment. ${ }^{4}$ Third, as noted, centrally driven efforts to revitalize regions outside of the CR have not shown measurable success.

While neo-developmentalism continues, democratization in the form of devolution of state power was moving toward realizing participatory planning through local governance and civic democracy.

\section{The rise of cities in governance: toward civic democracy (from the 2000s)}

The achievement of electoral democracy at the national level in 1987 is one of the most important accomplishments of the Korean miracle. Under President Kim Dae Jung, support of liberal democracy, namely, the rule of law and the freedoms of assembly and expression, also advanced. In 1995 the groundwork was laid for a third mode of democracy, civic democracy-active citizen participation in policymaking, planning and implementation-with the direct election of local governments, which also validated the rise of cities as loci of democratic governance. Possibilities for civic democracy were furthered in the early 2000 s when legislation was enacted to devolve substantial decision-making authority to local levels of government, including fiscal autonomy.

Heo and Hahm (2014) identify this third component of civic democracy as the one that consolidates democratic reform and promotes a profound shift in political culture, that is, a societal change in attitudes toward a civic orientation of collaboration with government. It does so by establishing cities and other local jurisdictions as levels of governance that most closely "responds to the will and needs of the people" and "becomes a high-quality civic democracy" (Cho 2014: 710). ${ }^{5}$ In Dahlgren's (2009) terms, civic and political culture intertwine through daily practices of participating in political life in tandem with engagements in social life (Reese and Rosenfeld, 2008). This understanding underscores the city as the level at which "civicism" can provide a counterpoint to the "statism" of Korea's mode of neo-developmentalism. Research finds that where it takes root, civic culture is durable through time (Rice and Arnett, 2001).

Civic democracy did not just appear with the devolution of state power to local governments. Korea has a substantial history of grassroots organizations and movements dating from at least the late Joseon Dynasty and throughout 
its period of colonization by Japan (Kim, 2017). More recently, however, devolution of governance has legitimated and substantially enhanced the capacities of city governments to respond to citizen concerns. This transformative institutional change in governance has created openings to what Castells (1997) calls a turn from mainly "resistance identities" to "project identities". In the same vein, Kim Pil Ho (2017: 3816) states that "grassroots community movements have acted as a critical social catalyst, exerting major influence on the country's shift from a modernist planning structure to a decentralized, participatory system". Analysis following renewed decentralization advances after 2002 also concludes that grassroots democracy allows communities everywhere to "create democracy models suitable for themselves" (Ha, 2007). Such conclusions underscore the likelihood of Korea to experience an increasing diversity of urban experiences.

From the 2011 elections onward, the election of a number of progressive city mayors have led to far-reaching departures from neo-developmentalism (Cho, 2019). A key factor in this change was what Chang and Bae (2012) call the "birth of social elections" in Korea. Instead of citizens voting on the basis of individual sourcing of information as in the past, the spread of social media provided the means to share information and enthusiasm that arose from and formed networks around issues of concern and the candidates who represented them. This new form of political mobilization inverted previous voting patterns dominated by older voters, a majority of whom allied with conservative parties. A majority of voters were now young and generally more progressive than their elders.

Policies enacted during the tenure of liberal presidents also played into the growing capacity of cities to govern. The Urban Planning Act of 2000 opened channels for popular participation in planning. The presidency of Roh Moo-hyun in 2002 pushed decentralization further by the adoption of regional balance through participatory governance. Civil society rose to the occasion through the formation of such alliances as the Civic Movement for Decentralization. The Livable City Building program launched in 2005 identified local participation in planning as a way to account for the unique characteristics of each city.

Following the array of legislation aimed at increasing capacities for local governance, a number of city governments were quick to adopt innovative urban policies for participatory governance. A short-list of the types of policies and programs that have been adopted by city governments, including Seoul (Cho, 2019; Douglass, 2019), cover four areas:

- Inclusion in public decision-making

- Participatory budgeting

- Direct citizen participation in government decision-making

- Distributive justice

- Social economy and community enterprises

- Sharing city

- Community currency

- Curtailing housing construction by housing destruction

- Social housing 
- Social and cultural conviviality

- (Re-)making the commons

- Transforming abandoned spaces into community centers

- (Re-)establishing open markets

- Participatory art and cultural festivals

- Promoting human scale architecture

- Revitalizing vernacular neighborhoods, including slums

- Environmental Wellbeing

- Reducing energy by “one less nuclear power plant" (Seoul)

- Urban farms and food gardens

- Alternative energy

- No car streets and "complete streets".

Seoul has led the way in creating alternatives to neo-developmentalism. Upon taking office in 2011, Mayor Park Won-soon cancelled the Han River global city megaprojects, adopted policies to stop massive clearance-based high-rise housing construction, moved to stop evictions that did not include relocation in new housing, initiated participatory budgeting, adopted a sharing car system, brought ordinary citizens into the government decision-making process, and supported community currency, among others. The city of Suwon has promoted a similar policy agenda, including a successful no-car streets campaign.

Many of the issues now being addressed by these local policy responses arose from impacts of neoliberal policies that Korea was compelled to adopt by the IMF after the 1997 AFC. These issues include high and rising income inequality (Kim, 2016), youth unemployment (Jung, 2017), senior poverty with high suicide rates (OECD, 2019), lack of low-income housing and rising costs of public transportation, schooling and food. More generally, they represent efforts to recover from the consequences of neo-developmentalism such as loss of neighborhoods and resident's place-making possibilities, public space, spontaneous cultural events and art festivals and environmental deterioration.

A major caveat to the discussion of diversity among cities is the continuing concentration of economic and social power in the CR (Lee and Shin, 2015). This pattern is manifest in the seriously declining capacities for local autonomy in government financing. From 2000 to 2013, the number of localities capable of generating at least one-third of their financial needs substantially declined to a point that the only local ones capable of generating more that 65 percent of their budgets were in the CR.

The implications of continuing growth of the $\mathrm{CR}$ and faltering economies with declining fiscal capacities elsewhere in the nation are that, in spite of all the policies for regional balance, Korea appears to be moving toward an extended city-state radiating from Seoul. If so, Korea would not be alone. While theoretical debates on spatial polarization remain unresolved, comparative research on actual experiences in Asia and around the world show that spatial polarization of the population and economy has increased over the past several decades (Jones and Douglass, 2008; Khanna, 2016). ${ }^{6}$ About one-third of the population 
of Japan lives in the Kanto region surrounding Tokyo, and its population share is increasing. The Pearl River Delta, the Greater Shanghai region and Jing-JinJi region expanding from Beijing each have urban populations approaching 100 million (Khanna, 2016). In 2019, more than one-quarter of the population of the Philippines archipelago lived in Greater Metro Manila, and the extended metropolitan region of Jakarta has a population of 31 million, making it the largest metropolitan region in the world after Tokyo. In sum, no country has managed to diminish the share of national populations in its principal metropolitan region.

If at all possible, ameliorating such an outcome in Korea would require as yet untried bold initiatives to enormously increase transfers to local levels, loosen the taut strings that continue to tie local policymaking to central bureaucracies and drastically reduce public financing of neo-developmental projects. The role of national government in a decentralized system of governance would then be one of redistribution of financial, material resources and professional assistance to local levels of governance to level the playing field and ensure basic levels of life chances across the national territory. The principle would echo the idea of subsidiarity, namely, that all political powers would be devolved to local jurisdictions unless convincing reasons can be given for assigning them to higher level ones (Barber and Ekins, 2016).

Whether such major departures from prevailing political structures would either be adopted or would work is an open question, but the alternative of continuing top-down public-corporate partnerships in master planning as the principal form of spatial planning has already lost any social and economic purpose that it might once have been presumed to have had. Korea's population is projected to decline from its 52 million peak in 2028 to 39 million in 2065 (Korea Times, 2019). By 2050 it will have become a super-aged society, with 40 percent of its population over age 65 ; outside the CR this share is projected to be as high as 80 percent. Rather than continuing to construct vast new towns with surplus housing and industrial complexes to stimulate regional revitalization, the moment has arrived to work with people to upgrade existing housing and reinvigorate their neighborhoods, for aging in place through participatory modes of spatial planning, and for an economy that uses the talents of an aging society in rewarding ways rather than pushing the elderly into poverty. Civic democracy might not be able to carry the weight of such hopes, particularly outside the CR, but promising outcomes have already been accomplished in several cities (Joo, 2019; Cho, 2019; Valmero, 2015).

\section{Conclusions}

Korea has achieved unparalleled successes over a historically short period of time from the 1960s. By 2018, it had a global reputation for technological innovation, its GDP per capita was slightly above the EU average and it ranked among the highest in the world in health standards and educational attainment (Seth, 2019). Along with these successes it has confronted issues 
of accountability of governance over, inter alia, human rights and basic freedoms, inequality, irregular employment, dispossessions of land, environmental destruction and heavy-handed use of state power in spatial planning. Achieving its successes and addressing discontent have rested on the capacity of Korean society to dynamically reform its political system to pursue fundamental transformations in relations among government, civil society and the corporate economy. The major shifts have been from authoritarian developmental state planning of the 1960s and 1970s to neo-developmental state and corporate economy collaborations from the 1980s, coupled with democratization, and, most recently, a trajectory toward civic democracy following devolution of governance to local levels.

From 1987 successive presidents have put forth their own mix of statecorporate and socially engaged concepts for spatial planning. Sonn and Lee (2015: 364) identify this feature of the Korean polity as the key to its resilience, namely, a heterogeneity that "combines political liberalism, economic conservatism, resistant regionalism, and localism" in ways that have allowed the state to maintain a strong position as regulator and policy leader while responding to neo-developmental and democratic voices. In other words, rather than having a static model of governance, Korea has proven to be adaptive. From this perspective, Korea does not fit into the pattern of contemporary neoliberalism in which government moves into the background of the corporate economy (Park, Richard and Asato, 2012; Chung, 2019). It has chartered its own way forward in the dynamics of changing relations of power that continue to be characterized by a strong state even with the rise of the chaebol dominating the economy and civil society successfully winning democratic freedom and the right to participate in governance.

However, the path dependency of attempts to change political structures have also limited the direction and scope of adaptation, which is manifested by the persistence of neo-developmentalism despite democratization and devolution of political power (Choi, Lee and Kim, 2019). From this perspective, when taking into account all of the turning points in the economy, the wide range of political orientations of political leaders and the tenacity of political and economic institutions, transformations in the political economy of spatial planning in Korea do not support either the simplistic notions of a linear development path determined by economic growth, or, therefore, the position that societies can or should choose to economically grow first and then move on to consider a social and environmental agenda later (Yap, 2011). The entire period of transformation in Korea's political economy from the 1960s to the present has been rife with political and economic crises, major confrontations between state and civil society and unexpected impacts of changing global forces. Worthy of note in this regard is Amsden's (1992) famous statement that Korea's success was achieved by getting "prices wrong" through strong state protection against manufactured imports — not by being determined by unfettered markets. ${ }^{7}$ All of these understandings lead to the conclusion that the miracles Korea has achieved and the unresolved problems attending them are outcomes of contestations and 
realignments among and within the state, civil society and corporate economy that have had no predetermined outcomes.

Critical assessments of neo-developmentalism have generated a chorus of calls for a paradigm shift in spatial planning toward inclusive, people-centered, socially just and environmentally sound processes of governance (Park, 2018; Choi and Kim, 2018; Kim and Lim, 2016). This brings to the fore the need to separate decentralization from the pursuit of regional balance. Advocating decentralization of planning with local autonomy sets in motion open-ended spatial processes of governance and the distribution of economic, social and environmental benefits. Some city regions will find their way forward through active citizen participation, while many others will continue to rely on neo-developmental types of top-down investments with token citizen participation. Further, under current trends, while major city regions might thrive, other settlements are likely to shrink to levels below which they can no longer be sustained or even inhabited. Consolidating smaller settlements into larger ones would only be short-term solutions unless much greater support is provided for them to find a new economic base through their own collaborations.

The miracles of Korea are not only to be found in stellar economic growth rates over several decades. They most profoundly derived from the capacity of the Korean people to secure transformations in processes of governance from authoritarian rule to participatory democracy within an exceptionally compressed period of their history. While economic growth contributed to the rise of civil society, democratic outcomes were not preordained. As the Korea experience shows, inclusive governance was achieved through indefatigable social insurgencies for political reforms in a setting in which government was ultimately capable of instituting them. A look around Asia and the rest of the world readily shows that democratic governance is not secure at any level of per capita income. Devolved forms of local democratic governance are even less apparent. In this, the world's first urban century, cities in most countries in Asia still do not have elected governments, nor do they have the personnel, expertise or financial resources to independently promulgate and implement policies.

Recent statements by the United Nations declaring that democracy is in retreat around the world makes the issue of democratic governance one of the most salient at the current juncture in history (Freedom House, 2019). Korea is now identified as one of only five full democracies in Asia. This is arguably the most impressive of all the gains of the country over the past six decades of national development.

\section{Notes}

1 Korea is used interchangeably with South Korea.

2 Until the 1980s, the number of countries signing bilateral investment treaties indicating openness to global investment averaged less than ten per year. The number skyrocketed in the 1980s to reach nearly 200 per year by the 1997 Asia Finance Crisis (Elkins, Guzman and Beth, 2006). 
3 According to the Third National Land Development Plan 1992-2001, in 1988 the Capital Region had an economic and social opportunity index of 141 compared to 67 for the rest of the nation $(100=$ weighted average $)$.

4 The 1988 Olympics—a huge neo-developmental project-infamously displaced more than 700,000 people. The Hadid Dongdaemun Design Plaza, which contributed to Seoul's rising public debt under the neoliberal government in the first decade of this century, cost more than US\$ half billion to construct.

5 Worthy of note in this regard is a study of 158 countries that finds corruption to be lower in decentralized government systems, the reason being the greater ability of citizens to have voice and accountability over public matters (Ivanyna and Shah, 2011).

6 Neoclassical economists theorize that spatial polarization will eventually equilibrate over time (Hirschman, 1975). Other theorists argue that it will not automatically reverse itself; nor, due to heavy biases in public spending on primate cities and lack of knowledge about opportunities elsewhere, is it economic efficient (Myrdal, 1957; Friedmann, 1973; Smith, 1990; Jones and Douglass, 2008).

7 In addition, "authoritarian capitalism" persists in countries with very high levels of per capita GDP (Carney, 2018).

\section{References}

Amsden, A. H. (1992). Next Giant: South Korea and Late Industrialization. Oxford: Oxford University Press.

Barber, N. W. and R. Ekins (2016). "Situating Subsidiarity," The American Journal of Jurisprudence 61(1), pp. 5-12.

Carney, R. (2018). Authoritarian Capitalism. Cambridge: Cambridge University Press.

Castells, M. (1997). The Power of Identity. Cambridge, MA: Blackwell.

Cha, B. (1998). "Four Customs-Free Zones to Be Set Up," Chosun Ilbo, December 22.

Chandler, M. (2010). "South Korea: Paradox of Rural Education," Global Post. Available at: www.pri.org/stories/2010-12-23/south-korea-paradox-rural-education. [Accessed February 20, 2020].

Chang, D. and Y. Bae (2012). The Birth of Social Election in South Korea. Berlin: Fesmedia Asia for Friedrich-Ebert-Stiftung.

Cho, M. (2019). "A Progressive City in the Making-The Seoul Experience," in M. Douglass, R. Garbaye and K. Ho (eds.), The Rise of Progressive Cities East and West. Singapore: Springer, pp. 47-64.

Cho, Y. (2014). "Appraising the Quality of Democracy as a Developmental Phenomenon: How South Koreans Appraise the Quality of Their Democracy," Social Indicators Research 116(3), pp. 699-712.

Choi, C., H. Lee and E. Kim (2019). "Critical Junctures and Path Dependence in Urban Planning and Housing Policy: A Review of Greenbelts and New Towns in Korea's Seoul Metropolitan Area," Land Use Policy 80, pp. 195-204.

Choi, M. and Y. Kim (2018). "Planning Paradigm Shift in the Era of Transition from Urban Development to Management: The Case of Korea," in A. Frank and C. Silver (eds.), Urban Planning Education. Heidelberg: Springer, pp. 161-174.

Chung, J. (2019). “The Neo-Developmental Cultural Industries Policy of Korea: Rationales and Implications of an Eclectic Policy," International Journal of Cultural Policy 25(1), pp. 63-74. 


\section{Mike Douglass}

Dahlgren, P. (2009). Media and Political Engagement. Cambridge: Cambridge University Press.

Douglass, M. (1994). “The 'Developmental State' and the Newly Industrialized Economies of Asia," Environment and Planning A 26(4), pp. 543-566.

Douglass, M. (2014). "The Saemaul Undong in Historical Perspective and in the Contemporary World," in I. Yi and T. Mkandawire (eds.), Learning from the South Korean Developmental Success. London: Palgrave Macmillan, pp. 136-171.

Douglass, M. (2019). “The Rise of Progressive Cities for Human and Planetary FlourishingA Global Perspective on Asia's Urban Transition," in M. Douglass, R. Garbaye and K. C. Ho (eds.), The Rise of Progressive Cities East and West. Singapore: Springer, pp. 23-46.

Elkins, Z., A. T. Guzman and S. Beth (2006). Competing for Capital: The Diffusion of Bilateral Investment Treaties 1960-2000. Berkeley. CA: ALACDE Annual Papers 29. University of California at Berkeley.

Evans, P. (1989). "Predatory, Developmental and Other Apparatuses: A Comparative Political Economy Perspective on the Third World State," Sociological Forum 4(4), pp. 561-587.

Evans, P. (1995). Embedded Autonomy: States and Industrial Transformation. Princeton: Princeton University Press.

Freedom House. (2019). Freedom in the World 2019. Available at: https://freedomhouse. org/report/freedom-world/freedom-world-2019/democracy-in-retreat. [Accessed July 20, 2019].

Friedmann, J. (1973). Urbanization, Planning and National Development. Beverly Hills: Sage.

Froebel, F., H. Jürgen and K. Otto (1980). The New International Division of Labor. London: Cambridge University Press.

Ha, S. (2007). Regions, Local Autonomy, and Democracy. Seoul: Humanitas.

Ha, Y. and M. Kang (2011). "Creating a Capable Bureaucracy with Loyalists: The Internal Dynamics of the South Korean Developmental State, 1948-1979," Comparative Political Studies 44(1), pp. 78-108.

Heo, U. and S. Hahm (2014). "Political Culture and Democratic Consolidation in South Korea," Asian Survey 54(5), pp. 918-940.

Hirschman, A. O. (1975). "Interregional and International Transmission of Economic Growth," in J. Friedmann and W. Alonso (eds.), Regional Policy, Readings in Theory and Application. Cambridge, MA: MIT Press, pp. 139-157.

Hwang, S. (2005). "Korea: U-city Project - Next IT Agenda," The Korea Herald. December 13, 2005.

Im, H. (1987). "The Rise of Bureaucratic Authoritarianism in South Korea," World Politics, 9(2), pp. 231-257.

Ivanyna, M. and A. Shah (2011). "Decentralization and Corruption: New Cross-Country Evidence," Environment and Planning C: Government and Policy 29, pp. 344-362.

Jones, G. and M. Douglass, eds. (2008). The Rise of Mega-Urban Regions in Pacific AsiaUrban Dynamics in a Global Era. Singapore: Singapore University Press.

Joo, Y. (2019). "Progressive Solutions to Urban Woes: Arts and Culture as Tools for Urban Revitalization in Busan, South Korea," in M. Douglass, R. Garbaye, and K. C. Ho (eds.), The Rise of Progressive Cities East and West. Singapore: Springer, pp. 217-231.

Jung, M. (2017). "Precarious Seoul: Urban Inequality and Belonging of Young Adults in South Korea," Positions 25(4), pp. 745-767. 
KDI (Korea Development Institute) (2015). "Evaluation of Special Economic Zone Policy and Suggestions for Vitalization of Free Economic Zone," KDI Focus. February 26, 2015.

KFEZ (Korean Free Economic Zones) (2019). "Where Business Blossoms." Available at: http://fez.go.kr/global/en/intro/greeting.do. [Accessed July 16, 2016].

Khanna, P. (2016). "Megacities, Not Nations, are the World's Dominant, Enduring Social Structures," Quartz. Available at: https://qz.com/666153/megacities-notnations-are-the-worlds-most-dominant-enduring-social-structures-adapted-fromconnectography/. [Accessed October 20, 2016].

Kim, C. (2016). "After Building Boom, South Korea Girds for Housing Glut," Reuters. March 16, 2016.

Kim, J. (2016). "Korea Worst in Income Inequality in Asia-Pacific," The Korean Times. Available at: www.koreatimes.co.kr/www/news/biz/2016/03/488_200524.html\#. [Accessed July 16, 2016].

Kim, J. and S. Choe (1996). Seoul: The Making of a Metropolis. London: John Wiley.

Kim, K. and M. Park (2016). Housing Policy in the Republic of Korea. Manila: Asian Development Bank Institute Working Paper, 570.

Kim, P. (2017). "Guns Over Rice: The Impact of US Military Aid on South Korean Economic Reconstruction," International Development and Cooperation Review 9(1), pp. 33-50.

Kim, S. (2017). "From Protest to Collaboration: The Evolution of the Community Movements amid Sociopolitical Transformation in South Korea," Urban Studies 54(16), pp. 3806-3825.

Kim, T. (2008). "Mayor Eyes Second Miracle on Han River," Korea Times. Available at: www.koreatimes.co.kr/www/news/special/2008/07/229_12815. [Accessed July 16, 2016].

Kim, T. and J. Lim (2016). Regional Policy in the Republic of Korea: Principles and Experiences. Santiago: Rimisp Working Paper, 189.

Kim, Y. (1995). "Spatial Changes and Regional Development," in G. Lee and H. Kim (eds.), Cities and Nation; Planning Issues and Policies of Korea. Seoul: KRIHS, pp. 53-78.

Kim, Y. (2000). "Spatial Development Policy—Spatial Development," Proceedings from the OECD Korea Workshop on Spatial Policies and Issues, Seoul, March 8-9, 73-95.

Korea Times (2010). "Gwangyang Free Economic Zone Emerges as Mega Hub." www. koreatimes.co.kr/www/news/biz/2010/11/123_76769.html. [Accessed May 10, 2019].

Korea Times (2019). "Korea's Population Likely to Peak in 2028." Available at: www. koreatimes.co.kr/www/nation/2019/03/703_266208.html\#. [Accessed July 15, 2019].

KRIHS (Korea Research Institute for Human Settlements) (1994). "Consolidated Cites," Space and Environment November, p. 4.

Lee, H., M. Lee, and D. Park (2012). Growth Policy and Inequality in Developing Asia: Lessons from Korea. Manila: Asia Development Bank, ERIA Discussion Paper Series, ERIA-DP-2012-12.

Lee, K. and D. Shin (2015). Concentrated Growth and Spatial Disparities in Korea. ERSA 55 th Congress, Lisbon, 26 August.

Lee, S., H. You and H. Kwon (2015). "Korea's Pursuit for Sustainable Cities through New Town Development: Implications for LAC," IDB (Inter-American Development Bank, Discussion Paper IDB-DP-390. 


\section{Mike Douglass}

Lee, S., J. Han, T. Yoon and Y. Tan (2008). “Towards Ubiquitous City: Concept, Planning, and Experiences in the Republic of Korea," in T. Yigitcanlar, K. Velibeyoglu and S. Baum (eds.), Knowledge-Based Urban Development: Planning and Applications in the Information Era. Hershey, PA: IGI Global, pp. 148-169.

LHI (Land \& Housing Institute) (2014). National Report for Habitat III. Seoul: Ministry of Land, Infrastructure and Transport.

Minns, J. (2001). “The Labour Movement in South Korea," Labour History 81, pp. 175-195.

MOLIT (Ministry of Land, Infrastructure and Transport) (2015). New Town Policy of Korea. Seoul: MOLIT.

Myrdal, G. (1957). Economic Theory and Underdeveloped Regions. London: Methuen.

Myrdal, G. (1970). “The 'Soft State' in Undeveloped Countries," in P. Streeten (ed.), Unfashionable Economics: Essays in Honour of Lord Balogh. London: Weidenfeld and Nicolson, pp. 227-243.

OECD (2019). “OECD Better Life Index - Korea." Available at: www.oecdbetterlifeindex. org/countries/korea/. [Accessed February 20, 2020].

Park, B., C. Richard and S. Asato, eds. (2012). Locating Neoliberalism in East Asia: Neoliberalizing Spaces in Developmental States. Malden, MA: Wiley-Blackwell.

Park, B., W. Lee, C. Hwang, J. M. Choi, J. N. Choi and C. Gregory, eds. (2016). The National Atlas of Korea, Volume III: Human Geography. Seoul: Ministry of Land, Infrastructure, and Transport; and National Geographic Information Institute (NGII), Republic of Korea.

Park, S. (2018). Urban Challenges and Planning Responses in South Korea. The Second Spatial Planning Platform Meeting. July 31-August 1. Fukuoka, Japan.

Reese, L. and R. A. Rosenfeld (2008). "Introduction: Comparative Civic Culture," Journal of Urban Affairs 30(4), pp. 355-374.

Rice, T. W. and M. Arnett, (2001). "Civic Culture and Socioeconomic Development in the United States: A View from the States, 1880s-1990s," The Social Science Journal 38(1), pp. 39-51.

Seth, M. (2019). South Korea's Economic Development, 1948-1996. Oxford Research Encyclopedia, Asian History. Available at: https://oxfordre.com/asianhistory/view/ 10.1093 /acrefore/9780190277727.001.0001/acrefore-9780190277727-e-271. [Accessed August 18, 2020].

Smith, N. (1990). Uneven Development: Nature, Capital, and the Production of Space. Georgia: University of Georgia Press.

Sonn, J. and D. Lee (2015). "Heterogeneity as the Source of the State's Resilience: The Case of Spatial Planning Under State-led Neoliberalization in South Korea," International Journal of Urban Sciences 19(3), pp. 364-378.

Tacoli, C., ed. (2006). Rural-Urban Linkages. London: Earthscan.

Valmero, A. (2015). "The Long-Term Impact of a Month Without Cars," CityLab. Available at: www.citylab.com/commute/2015/10/the-long-term-impact-of-amonth-without-cars/412408/. [Accessed May 3, 2019].

Yap, O. F. (2011). "A Strategic Model of Economic Performance and Democratization in South Korea and Taiwan," British Journal of Political Science 42(1), pp. 213-239. 


\title{
3 Korea's regional development policy
}

\author{
Understanding its context and \\ drawing implications for international \\ development cooperation
}

\author{
Won Bae Kim
}

\section{Introduction}

As well documented in the history of the Korean economy, economic development was the primary national goal in Korea's early phases of development (Sakong and Koh, 2010). Efficiency was a governing principle in major investment decisions. Places were treated simply as locations for economic growth. Furthermore, local and regional administrations did not have a voice in a highly centralized decision-making process. An authoritarian government that had presided over rapid economic growth came to an end around the late 1980s and a democratic government has been established since the early 1990s. With the election of local leaders by citizens in 1995, Korea became involved in political decentralization, gradually allowing localities the joint governance of cities and provinces. ${ }^{1}$ On the whole, however, Korea's institutional framework has been and still is highly centralized. Sub-national governments are still lacking autonomy and space for strategic planning. This has been further constrained by the limited financial autonomy of sub-national governments (OECD, 2012).

As Korea has moved towards a democratic society, there has been a gradual shift from efficiency to equity concerns, including balanced regional development (Cha, 2017). This shift has become evident since the 2000s when Korea experienced social and economic polarization due to market opening and liberalization policies. In parallel with a shifting emphasis from efficiency to equity, policy approaches to regional development have somewhat changed from "placeneutral" to "place-based": the former advocated by the World Bank and the latter by the OECD. Even though major programs are still oriented towards building hardware such as techno parks and innovation districts, some efforts for capacity building at the local and regional levels are being carried out. In short, Korea's experience adds an interesting perspective to the literature on development in general and regional development in particular as well as related policy debates surrounding "efficiency versus equity" and "place-neutral versus placebased" approaches. Moreover, Korean experience provides a variety of policy experiments encompassing both successes and failures in regional development. 
Developing countries can certainly apply some of Korea's policies and programs through a careful assessment of their institutional context, development priorities and the availability of resources.

\section{Korea's politico-economic context and major processes underlying regional development}

Korea has undergone a rapid politico-economic transformation in the past six decades, achieving both economic and political development. Korea's economic transformation has been remarkable and is often praised as a success story. Korea's GDP per capita was US\$158 in 1960 and US\$29,743 in 2017. The share of agriculture in GDP decreased from 36.2 percent in 1960 to 2 percent in 2017, while the share of manufacturing in GDP increased from 11.2 percent in 1960 to 27.6 percent in 2017. Korea was not a trading country in 1960; now, it is a heavy trading country comparable to the European Union (World Bank, World Development Indicators, various years). Politically, Korea transformed from an authoritarian government to a democratic government in the 1990s, during which time decentralization processes have also taken place. With slow economic growth in recent years, Korea is facing yet another major transformation, namely, demographic transition. Korea will soon face a declining national population with an already shrinking population in smaller cities and rural areas. Regional development in Korea's rapidly changing environment needs to be looked at from a holistic perspective over a long duration.

The intertwined processes of industrialization and urbanization are pertinent to any country's regional development. Labor transfer from agricultural to nonagricultural sectors usually involves changes in residence. In the case of Korea, it generated massive flows of rural-to-urban migration during the 1960s, 1970s, and 1980s, thereby reshaping Korea's geo-economic landscape (Choe and Kim, 2001; Kim, 2012). The proportion of urban dwellers in the national population increased from 28 percent in 1960 to 82 percent in 2017. Also prominent in Korea's urbanization process is the role of a million plus cities in its spatioeconomic development. Most of those million plus cities are metropolitan cities that are comparable to provinces (Table 3.1). In brief, industrialization and urbanization were two underlying forces behind regional development in Korea until the late 1980s.

Both processes slowed down as the Korean economy began to lose its comparative advantage in low-wage industries in the late 1980s. Instead, globalization and localization processes have begun in the national economy as well as regional economies since the 1990s. The 1997 economic crisis, which epitomized the vulnerability of externally dependent economies such as Korea, brought not only a heavy blow to the national economy but also revealed sharp differentials in ability for economic recovery and resilience to the crisis between cities and regions, calling for measures to enhance regional capability to cope with crises as well as to build diversified bases for regional economies (Kim and Shin, 2013; Kim, 2003a; Kim, 1998). 
Table 3.1 Distribution of population in metropolitan cities and provinces, 1960-2017

\begin{tabular}{|c|c|c|c|c|c|c|c|c|}
\hline & Year & 1960 & 1970 & 1980 & 1990 & 2000 & 2010 & 2017 \\
\hline Country total & & 24,989 & 32,241 & 38,124 & 42,869 & 47,008 & 49,554 & 51,446 \\
\hline $\begin{array}{l}\text { Metropolitan } \\
\text { cities }\end{array}$ & $\begin{array}{l}\text { Seoul } \\
\text { Busan } \\
\text { Daegu } \\
\text { Incheon } \\
\text { Gwangju } \\
\text { Daejeon } \\
\text { Ulsan }\end{array}$ & 2,445 & $\begin{array}{l}5,686 \\
2,046\end{array}$ & $\begin{array}{l}8,516 \\
3,309\end{array}$ & $\begin{array}{l}10,473 \\
3,803 \\
2,293 \\
1,897 \\
1,125 \\
1,036\end{array}$ & $\begin{array}{l}10,078 \\
3,733 \\
2,529 \\
2,522 \\
1,382 \\
1,397 \\
1,036\end{array}$ & $\begin{array}{l}10,089 \\
3,477 \\
2,480 \\
2,723 \\
1,494 \\
1,515 \\
1,099\end{array}$ & $\begin{array}{l}9,776 \\
3,429 \\
2,465 \\
2,923 \\
1,501 \\
1,531 \\
1,166\end{array}$ \\
\hline $\begin{array}{l}\text { Special } \\
\text { administration } \\
\text { city }\end{array}$ & Sejong & & & & & & & 276 \\
\hline Provinces & $\begin{array}{l}\text { Gyeonggi } \\
\text { Gangwon } \\
\text { Chungbuk } \\
\text { Chungnam } \\
\text { Jeonbuk } \\
\text { Jeonnam } \\
\text { Gyeongbuk } \\
\text { Gyeongnam } \\
\text { Jeju }\end{array}$ & $\begin{array}{l}2,749 \\
1,637 \\
1,370 \\
2,528 \\
2,395 \\
3,553 \\
3,848 \\
4,182 \\
282\end{array}$ & $\begin{array}{l}3,440 \\
1,914 \\
1,516 \\
2,927 \\
2,491 \\
4,101 \\
4,669 \\
3,078 \\
374\end{array}$ & $\begin{array}{l}5,028 \\
1,824 \\
1,450 \\
3,011 \\
2,329 \\
3,848 \\
5,045 \\
3,292 \\
472\end{array}$ & $\begin{array}{l}5,972 \\
1,562 \\
1,374 \\
1,992 \\
2,047 \\
2,480 \\
2,736 \\
3,570 \\
509\end{array}$ & $\begin{array}{l}9,146 \\
1,516 \\
1,494 \\
1,879 \\
1,927 \\
2,035 \\
2,773 \\
3,036 \\
524\end{array}$ & $\begin{array}{l}11,619 \\
1,489 \\
1,524 \\
2,078 \\
1,796 \\
1,777 \\
2,630 \\
3,217 \\
548\end{array}$ & $\begin{array}{l}12,809 \\
1,521 \\
1,605 \\
2,148 \\
1,830 \\
1,796 \\
2,681 \\
3,355 \\
634\end{array}$ \\
\hline Capital Region & $\begin{array}{l}\text { Population } \\
\text { Share (\%) }\end{array}$ & $\begin{array}{l}5,194 \\
20.8\end{array}$ & $\begin{array}{l}9,126 \\
28.3\end{array}$ & $\begin{array}{l}13,544 \\
35.5\end{array}$ & $\begin{array}{l}18,342 \\
42.8\end{array}$ & $\begin{array}{l}21,747 \\
46.3\end{array}$ & $\begin{array}{l}24,431 \\
49.3\end{array}$ & $\begin{array}{l}25,509 \\
49.6\end{array}$ \\
\hline Southeast Region & $\begin{array}{l}\text { Population } \\
\text { Share (\%) }\end{array}$ & $\begin{array}{l}4,182 \\
16.7\end{array}$ & $\begin{array}{l}5,124 \\
15.9\end{array}$ & $\begin{array}{l}6,601 \\
17.3\end{array}$ & $\begin{array}{l}7,373 \\
17.2\end{array}$ & $\begin{array}{l}7,805 \\
16.6\end{array}$ & $\begin{array}{l}7,793 \\
15.7\end{array}$ & $\begin{array}{l}7,950 \\
15.5\end{array}$ \\
\hline
\end{tabular}

Source: Kosis. Population prospects and figures for 1960 are from nationalatlas.ngii.go.kr/ 인구성장과\%인구분포 $\% 20(3) \cdot p d f$

Notes: Units are per thousand persons. Capital Region includes Seoul, Incheon, Gyeonggi; Southeast Region includes Busan, Ulsan, and Gyeongnam.

The genesis of Korea's uneven regional development and the policy efforts to combat spatial agglomerations stems from its industrialization process, which requires a detailed description to provide useful information to developing countries in the early phases of industrialization. Korea's industrial development has gone from labor-intensive, through capital-intensive, to technology- and knowledge-intensive phases over the past six decades. Korea recorded close to a 10 percent annual growth rate for GDP from the 1960s to the 1980s, gradually tapering down to below 10 percent and, more recently, below 3 percent. This growth performance roughly coincides with the above industrial transition phases: high in the labor-intensive and capital-intensive phases and low in the technology- and knowledge-intensive phase. Moreover, there are also indications that there is less room for maneuvering the space for economic development as deindustrialization processes have settled in. Three phases of industrialization and associated regional development are briefly sketched below. 
During its export-oriented, labor-intensive industrialization phase from the 1960 s to the 1970s, economic development was the foremost national goal of Korea. Because of Korea's poor resource endowments, labor was the only comparative advantage that Korea had at the time. Labor-intensive export industries began to be developed in large cities such as Seoul, Busan and Daegu. For example, Seoul's population tripled between 1960 and 1980, while the population of Busan and Daegu more than doubled (Choe and Kim, 2001). This trend continued during the 1980s, generating policy concerns over the high population concentration in Seoul and a few other large cities. There were some attempts to limit the growth of large cities, in particular Seoul, in the 1960s and 1970ssuch as the containment of large city populations in 1964, the containment of the Capital Region (CR) population in 1969, and the "greenbelt" policy of 1971. These policies were devised to abate urban problems as well as for national security reasons. Seoul was simply too close to the demilitarized zone, exposing itself directly to North Korea's artillery range (Joh, Kim and Koh, 2010).

Around the late 1960s, the Korean government considered industrial restructuring, given the limited prospect of labor-intensive industries for national economic development. The strategy adopted was the promotion of heavy and chemical industries. Government efforts began in earnest after the announcement of the heavy and chemical industry development plan in 1973 (Kim and Koh, 2010). Large industrial complexes and necessary infrastructure were constructed during the 1970s. The major requirement was efficient locations for the import of raw materials and export of refined products. Coastal locations, mostly in the southeast coastal areas, were selected for these large industrial complexes. As a result, Korea's industrial space was polarized between the CR and the Southeast Coastal Region (SCR), leaving a legacy of uneven industrial growth across the regions.

As Korea's manufacturing industries grew continuously from the 1970s to the 1980s, more opportunities arose for the development of industrial parks in inland areas. In contrast to the earlier periods, a large number of industrial parks have been developed by local governments since 2000. As a result, industrial development has spread across the regions, reducing imbalances in industrial production between regions. The southwest (Jeolla) and Chungcheong region have gained a significant number of industrial parks since 1980 (Ryu, 2018). However, industrial parks, which have been a major tool for Korea's industrial development and partly for its regional development, have recently been facing a number of challenges, such as technological obsolescence and facility degradation. As Korea becomes a more knowledge-intensive economy, shifting from an investmentdriven to an innovation-driven mode, those industrial parks depending on traditional manufacturing technology need to be renovated and transformed into innovation-oriented sites incorporating research and development as well as the amalgamation of services and distribution with production.

Since the early 1990s, the Korean economy has been undergoing structural changes. The manufacturing sector is no longer the major employer. Even though deindustrialization did not occur in terms of current and real value 
added in Korea, it did begin in terms of employment in 1991 (Oh, 2009). Manufacturing employment as an absolute number hit its peak in 1991 and has been declining ever since. Moreover, the transition into a knowledge economy from a traditional manufacturing economy has required the adoption of advanced technology and innovative practices. Obviously, large enterprises endowed with the necessary skills and R\&D capacity fared better and, as a corollary, regions with large enterprises and connected R\&D institutions performed better than regions with branch plants and production facilities. The deindustrialization process that began in the 1990s was accelerated by the 1997 economic crisis due to market liberalization and neoliberal policies. Since then, regional disparities have increased. More importantly, social and economic polarization has begun to surface as a national problem since the 2000s. Imbalanced regional development should thus be understood as a concomitant of these broad socioeconomic changes in Korea. In fact, reducing inter-regional disparity may not contribute to reducing social inequality, that is, improving income distribution across or within a region $(\mathrm{Kim}, 2010)$.

\section{Policy responses to the concentration in the $\mathrm{CR}$ and regional disparity}

\section{Institutional context}

Territorial planning, including regional policy carried out in a centralized political system, has been effective in supporting national economic development mainly through industrial parks and infrastructure construction programs (Moon et al., 2013). However, rapid economic development during the 1960s and 1970s has engendered a heavy concentration of population and industry in the CR and partly in the SCR. During the 1980s, policymakers at the central government felt the need to curb the concentration in the $\mathrm{CR}$ and to promote the development of lagging regions. With a trend of concentration in the CR continuing during subsequent decades, the central government sought to halt the trend and took diverse policies to curb concentration in the $\mathrm{CR}$ as well as to promote regional development outside of the CR. This approach has been top-down and focused on de-concentration and dispersion, paying less attention to the self-reliant development of regions until the early 2000s (OECD, 2012). Due to the slow decentralization of power, regions and localities are still dependent on the central government for policy initiatives and resources.

This dependency creates another important characteristic of the Korean model of regional development, namely, how the national government takes into account its territory and local constituencies as key elements in policy planning (OECD, 2012). Regionalism plays an important role here (Choe, 2014, 2015, 2016; Kim, 2003b; Kim, 2003; Sonn, 2003). Even though regionalism itself is not necessarily a negative element in socioeconomic development, it can become detrimental when national political elites manipulate it for their own benefit (Kim, 2003a; and Kim, 2003b). ${ }^{2}$ This "political regionalism" emerged when Korea 
began to revive local autonomy in the 1990s. ${ }^{3}$ Regional/local interests prevailed in local elections and regions/localities joined in a competition for their share in national resource allocation. National politicians were not idle in manipulating regionalism for their power grabs in national elections. Given the lack of fiscal independence in regions and localities, the central government has solidified its position vis-à-vis regional/local administrations through centralized fiscal power. To appease regional sentiments and to meet increasing demands for balanced regional development, regional policies since the 2000s have come to resemble numerical equalization across the regions (Cha, 2017; Choe, 2016).

\section{Facts about regional disparities}

Over the past 60 years, the regional distribution of production and population across Korea's administrative divisions has shown a strong tendency to concentrate towards the CR (Table 3.2). About half of national production and population are now concentrated in the CR, while the SCR, once the second pole of industrial growth in Korea, has been losing its share of production and population. From 1985 to 2017, the province of Gyeonggi within the CR recorded the largest gains in terms of production and population share, while all other metropolitan cities and most provinces recorded a loss. Chungbuk and Chungnam provinces were exceptions, having gained their production shares since 1990, clearly reflecting some effects of the government de-concentration policy begun in the 1980s. ${ }^{4}$

Table 3.2 provides another interesting observation related to a rough measure of relative regional productivity. With the exception of Ulsan, an industrial city that was developed in the 1970s as a part of heavy and chemical industry promotion policy, all other metropolitan cities experienced a decline in their relative productivity, measured roughly by each region's production share divided by its population share over time. Among the provinces, some improved and others declined in terms of relative productivity. Improvements were made in the provinces of Chungbuk, Chungnam, Gyeongbuk and Jeonnam. The cases of Chungbuk and Chungnam were closely related to the relocation or establishment of firms based in the CR.

On the whole, the heavy concentration of population and industries in the $\mathrm{CR}$ is remarkable. It is the highest concentration in a single region among the OECD countries, surpassing that of the core regions of Greece, Hungary, Chile and Japan, respectively (OECD, 2018). Such a high concentration of population and economic activities in a single region poses two important problems. One is brain and resources drain to the core region from other regions. In the case of Korea, this has been considered unacceptable for national integration. The other is negative externalities arising from heavy concentration in a single region. The Korean case is an interesting example. Almost half of the national population is living in the CR while contributing about half of GDP. This provides no evidence for any benefits of agglomeration economies since the relative productivity in the $\mathrm{CR}$ is not higher than in those of regions outside of the CR. ${ }^{5}$ An OECD report 
Table 3.2 Regional distribution of production and population

\begin{tabular}{|c|c|c|c|c|c|c|c|c|c|c|c|c|c|c|c|c|c|c|}
\hline \multirow[t]{2}{*}{ Region/year } & \multicolumn{6}{|c|}{ Regional share of GRDP (\%) } & \multicolumn{6}{|c|}{ Regional share of population (\%) } & \multicolumn{6}{|c|}{ GRDP share/population share } \\
\hline & 1985 & 1990 & 1995 & 2000 & 2010 & 2017 & 1985 & 1990 & 1995 & 2000 & 2010 & 2017 & 1985 & 1990 & 1995 & 2000 & 2010 & 2017 \\
\hline Seoul & 28.1 & 28.7 & 27.7 & 26.0 & 22.9 & 21.9 & 23.8 & 24.4 & 22.9 & 21.4 & 20.4 & 19.0 & 1.2 & 1.2 & 1.2 & 1.2 & 1.1 & 1.2 \\
\hline Busan & 8.0 & 7.5 & 6.5 & 5.8 & 5.0 & 4.8 & 8.9 & 8.9 & 8.5 & 7.9 & 7.0 & 6.7 & 0.9 & 0.8 & 0.8 & 0.7 & 0.7 & 0.7 \\
\hline Daegu & 4.9 & 4.7 & 4.0 & 3.6 & 3.0 & 3.0 & 5.2 & 5.3 & 5.5 & 5.4 & 5.0 & 4.8 & 0.9 & 0.9 & 0.7 & 0.7 & 0.6 & 0.6 \\
\hline Incheon & 4.8 & 5.2 & 5.5 & 4.6 & 4.8 & 4.7 & 3.8 & 4.4 & 5.2 & 5.4 & 5.5 & 5.7 & 1.3 & 1.2 & 1.1 & 0.9 & 0.9 & 0.8 \\
\hline Gwangju & & 2.4 & 2.4 & 2.2 & 2.1 & 2.0 & & 2.6 & 2.8 & 2.9 & 3.0 & 2.9 & & 0.9 & 0.8 & 0.7 & 0.7 & 0.7 \\
\hline Daejeon & & 2.7 & 2.5 & 2.4 & 2.2 & 2.1 & & 2.4 & 2.9 & 3.0 & 3.1 & 3.0 & & 1.1 & 0.9 & 0.8 & 0.7 & 0.7 \\
\hline Ulsan & & & & 5.7 & 5.0 & 4.7 & & & & 2.2 & 2.2 & 2.3 & & & & 2.6 & 2.2 & 2.1 \\
\hline Gyeonggi & 12.5 & 14.8 & 16.2 & 17.3 & 21.1 & 23.2 & 11.5 & 13.9 & 17.2 & 19.5 & 23.4 & 24.9 & 1.1 & 1.1 & 0.9 & 0.9 & 0.9 & 0.9 \\
\hline Gangwon & 4.8 & 3.9 & 3.2 & 2.8 & 2.4 & 2.4 & 4.3 & 3.6 & 3.3 & 3.2 & 3.0 & 3.0 & 1.1 & 1.1 & 1.0 & 0.9 & 0.8 & 0.8 \\
\hline Chungbuk & 3.4 & 3.0 & 3.2 & 3.1 & 3.1 & 3.6 & 3.4 & 3.2 & 3.1 & 3.2 & 3.1 & 3.1 & 1.0 & 0.9 & 1.0 & 1.0 & 1.0 & 1.1 \\
\hline Chungnam & 6.6 & 3.9 & 4.1 & 4.9 & 6.6 & 7.4 & 7.4 & 4.6 & 4.0 & 4.0 & 4.2 & 4.7 & 0.9 & 0.8 & 1.0 & 1.2 & 1.6 & 1.6 \\
\hline Jeonbuk & 4.3 & 3.4 & 3.5 & 3.3 & 2.9 & 2.7 & 5.4 & 4.8 & 4.3 & 4.1 & 3.6 & 3.6 & 0.8 & 0.7 & 0.8 & 0.8 & 0.8 & 0.7 \\
\hline Jeonnam & 8.3 & 5.7 & 5.7 & 5.3 & 4.7 & 4.4 & 9.3 & 5.8 & 4.6 & 4.3 & 3.6 & 3.5 & 0.9 & 1.0 & 1.2 & 1.2 & 1.3 & 1.3 \\
\hline Gyeongbuk & 6.4 & 5.8 & 5.4 & 6.2 & 6.4 & 6.0 & 7.2 & 6.4 & 6.0 & 5.9 & 5.3 & 5.2 & 0.9 & 0.9 & 0.9 & 1.0 & 1.2 & 1.2 \\
\hline Gyeongnam & 8.7 & 8.7 & 9.8 & 6.3 & 6.9 & 6.1 & 8.5 & 8.3 & 8.6 & 6.5 & 6.5 & 6.5 & 1.0 & 1.0 & 1.1 & 1.0 & 1.1 & 0.9 \\
\hline Jeju & 1.0 & 1.0 & 1.0 & 0.9 & 0.9 & 1.0 & 1.2 & 1.2 & 1.1 & 1.1 & 1.1 & 1.2 & 0.8 & 0.8 & 0.9 & 0.8 & 0.8 & 0.8 \\
\hline $\begin{array}{l}\text { Capital } \\
\text { Region }\end{array}$ & 45.4 & 48.7 & 49.3 & 47.9 & 48.8 & 49.8 & 39.1 & 42.8 & 45.3 & 46.3 & 49.3 & 49.6 & 1.2 & 1.1 & 1.1 & 1.0 & 1.0 & 1.0 \\
\hline $\begin{array}{c}\text { Southeast } \\
\text { Region }\end{array}$ & 16.8 & 16.2 & 16.3 & 17.8 & 16.9 & 15.7 & 17.4 & 17.2 & 17.2 & 16.6 & 15.7 & 15.5 & 1.0 & 0.9 & 1.0 & 1.1 & 1.1 & 1.0 \\
\hline
\end{tabular}

Sources: Kosis. Regional income and population prospects figures for 1960 are from nationalatlas.ngii.go.kr/인구성장과\%인구분포\%20(3).pdf

Notes: Chungnam includes Sejong special city in 2017. Seoul Capital Region includes Seoul, Incheon, and Gyeonggi; Southeast Region includes Busan, Ulsan, and Gyeongnam. 
(2007) observed that diseconomies of agglomeration-such as traffic congestion and air pollution-are present in the CR.

Across the regions, regional disparity measured in terms of per capita GRDP (gross regional domestic product) had been relatively small and stable until 1997 and modest in comparison with other OECD countries. The economic crisis of 1997 brought a significant economic disruption across the country and changed the regional economic landscape thereafter. Regional disparity increased and continued at a relatively higher level with moderate fluctuations (Figure 3.1). Compared with other OECD countries, however, regional disparity in Korea is still not particularly high $(\mathrm{OECD}, 2018) .{ }^{6}$ Such disparity is known to arise largely from labor productivity differentials between regions, especially in the processing and assembly industries within the manufacturing sector (Kim and Lee, 2010). A more important structural factor lies in the concentration of talents, technology and capital in the CR. As shown in Table 3.3, gaps between the CR and other regions in terms of the number of large corporations, managers and professionals and R\&D personnel persist and they are unlikely to be reduced in the near future. The effects of government dispersion policy are, however, present here as well. The provinces of Chungnam and Chungbuk, which have been the major beneficiaries of the dispersion policy, have shown gains. ${ }^{7}$

In this respect, the convergence hypothesis that regional income disparities tend to rise during the early development stages and then taper down as the

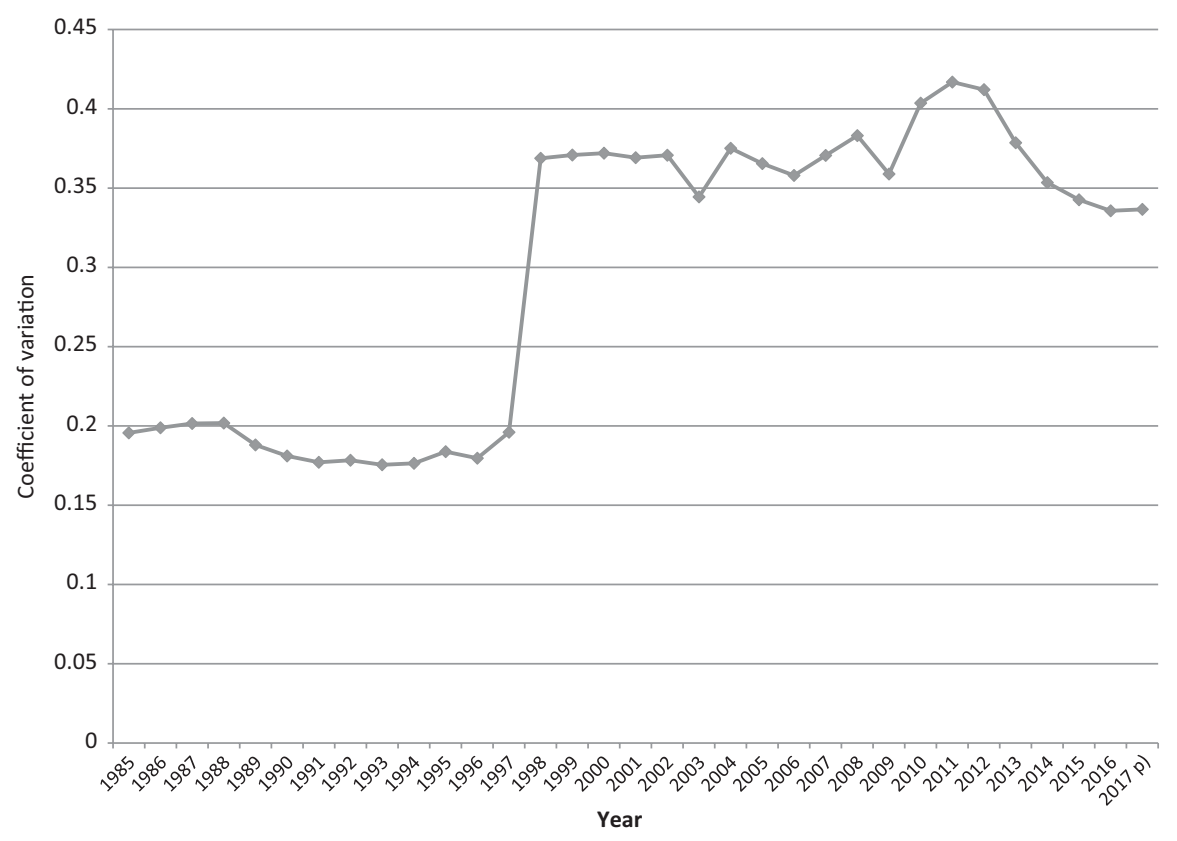

Figure 3.1 Regional disparity in Korea (per capita gross regional product).

Source: Kosis, Regional Income Account. 
Table 3.3 Skewed distribution of large corporations, professionals and R\&D personnel in Korea

\begin{tabular}{|c|c|c|c|c|c|}
\hline \multirow[t]{2}{*}{ Year } & \multicolumn{2}{|c|}{$\begin{array}{l}\text { Regional share of large } \\
\text { corporations }(300+ \\
\text { employees) (\%) }\end{array}$} & \multicolumn{2}{|c|}{$\begin{array}{l}\text { Regional share } \\
\text { of managers and } \\
\text { professionals (\%) }\end{array}$} & \multirow{2}{*}{$\begin{array}{l}\text { Regional share of } \\
\text { R\&D personnel } \\
(\%) \\
2010\end{array}$} \\
\hline & 2006 & 2017 & 2006 & 2017 & \\
\hline Country & 100.0 & 100.0 & 100.0 & 100.0 & 100.0 \\
\hline Seoul & 36.3 & 36.8 & 29.1 & 25.6 & 24.6 \\
\hline Incheon & 4.2 & 4.3 & 5.0 & 5.1 & 2.7 \\
\hline Gyeonggi & 15.3 & 17.0 & 25.0 & 28.1 & 46.5 \\
\hline CR & 55.7 & 58.1 & 59.1 & 58.8 & 73.8 \\
\hline Busan & 6.9 & 5.9 & 6.1 & 6.2 & 1.8 \\
\hline Ulsan & 2.1 & 2.4 & 1.7 & 1.7 & 0.3 \\
\hline Gyeongnam & 5.4 & 4.7 & 5.3 & 5.0 & 1.8 \\
\hline SCR & 14.4 & 13.1 & 13.1 & 12.9 & 3.9 \\
\hline Daegu & 3.3 & 3.2 & 4.6 & 4.4 & 0.9 \\
\hline Gyeongbuk & 5.7 & 4.3 & 3.4 & 3.1 & 1.8 \\
\hline Daejeon & 3.6 & 3.4 & 3.7 & 3.5 & 14.0 \\
\hline Chungnam & 4.4 & 4.7 & 2.8 & 3.7 & 1.2 \\
\hline Chungbuk & 2.6 & 3.3 & 2.1 & 2.6 & 0.9 \\
\hline Jeonbuk & 2.6 & 2.5 & 2.6 & 2.8 & 1.0 \\
\hline Gwangju & 2.2 & 2.3 & 3.2 & 2.9 & 0.7 \\
\hline Jeonnam & 2.5 & 2.1 & 2.2 & 2.2 & 0.8 \\
\hline Gangwon & 2.1 & 2.2 & 2.4 & 2.0 & 0.8 \\
\hline Jeju & 0.8 & 0.8 & 0.8 & 1.0 & 0.2 \\
\hline
\end{tabular}

Source: Kosis.

national economy matures does not hold over the long term in the Korean case. ${ }^{8}$ However, there is partial support for the hypothesis, though only over a limited period of time: From the 1960s to the 1990s, regions with high levels of agricultural employment and rapid population transition did catch up faster with high-income regions (Kim, 2003a). Furthermore, there have been some positive policy effects on the convergence process, especially through the industrial parks program and the dispersion policy.

\section{Evolution of regional policy in Kovea}

Korea's regional policy has evolved over time with changing developmental contexts and political structures (Table 3.4). National concerns have been shifting from growth to welfare and equity. Policy approaches have, however, been largely top-down. Main strategies have not changed much, mostly focusing on deconcentration and dispersion from the CR. A substantive break in policy orientation was made during the early 2000s when policymakers focused their attention on self-reliant regional development in a manner that resembled the place-based 
Table 3.4 Evolution of regional policy in Korea

\begin{tabular}{|c|c|c|c|c|c|}
\hline Period & $1960 s-1970 s$ & $1980 s$ & $1990 s$ & $2000 s$ & $2010 s$ \\
\hline Governance & $\begin{array}{r}\text { Authoritarian, } \\
\text { hierarchical }\end{array}$ & $\begin{array}{l}\text { Authoritarian, } \\
\text { hierarchical }\end{array}$ & $\begin{array}{l}\text { Democratic, local } \\
\text { autonomy introduced }\end{array}$ & $\begin{array}{l}\text { Democratic, local autonomy } \\
\text { enhanced }\end{array}$ & $\begin{array}{l}\text { Democratic, local } \\
\text { autonomy enhanced }\end{array}$ \\
\hline $\begin{array}{l}\text { Primary national } \\
\text { concerns }\end{array}$ & Growth & Growth & Growth with welfare & Growth with equity & $\begin{array}{l}\text { Inclusive growth and } \\
\text { competitiveness }\end{array}$ \\
\hline $\begin{array}{l}\text { Development } \\
\text { mode }\end{array}$ & $\begin{array}{l}\text { Labor and } \\
\text { investment } \\
\text { driven }\end{array}$ & $\begin{array}{l}\text { Investment and } \\
\text { technology } \\
\text { driven }\end{array}$ & $\begin{array}{l}\text { Transition to } \\
\text { knowledge-based } \\
\text { economy }\end{array}$ & Innovation driven & Innovation driven \\
\hline Regional concerns & $\begin{array}{l}\text { Concentration in } \\
\text { large cities and } \\
\text { the CR }\end{array}$ & $\begin{array}{l}\text { Concentration } \\
\text { in the CR and } \\
\text { SCR }\end{array}$ & $\begin{array}{l}\text { Concentration in the } \\
\mathrm{CR} \text {, regional disparity }\end{array}$ & $\begin{array}{l}\text { Concentration in the } \mathrm{CR} \text {, } \\
\text { regional disparity, regional } \\
\text { competitiveness }\end{array}$ & $\begin{array}{l}\text { Concentration in } \\
\text { the } \mathrm{CR} \text {, regional } \\
\text { disparity, welfare }\end{array}$ \\
\hline $\begin{array}{l}\text { Approach to } \\
\text { regional } \\
\text { development }\end{array}$ & $\begin{array}{l}\text { Top-down, mainly } \\
\text { dispersion }\end{array}$ & $\begin{array}{l}\text { Top-down, mainly } \\
\text { dispersion }\end{array}$ & $\begin{array}{l}\text { Top-down, mainly } \\
\text { dispersion }\end{array}$ & $\begin{array}{l}\text { Top-down, dispersion, self-reliant } \\
\text { regional development }\end{array}$ & $\begin{array}{l}\text { Top-down, dispersion, } \\
\text { self-reliant regional } \\
\text { development }\end{array}$ \\
\hline $\begin{array}{l}\text { Main policies and } \\
\text { plans }\end{array}$ & $\begin{array}{l}\text { Industrial location } \\
\text { policy, greenbelt } \\
\text { policy, industry } \\
\text { dispersion } \\
\text { policy }\end{array}$ & $\begin{array}{l}\text { CR management } \\
\text { policy, lagging } \\
\text { region } \\
\text { development } \\
\text { policy }\end{array}$ & $\begin{array}{l}\text { CR management policy, } \\
\text { regional industry } \\
\text { promotion program } \\
\text { (RIPP) }\end{array}$ & $\begin{array}{l}\text { CR management policy, five- } \\
\text { year Balanced Regional } \\
\text { Development Plan (BRDP), } \\
\text { RIPP and techno parks, } \\
\text { regional innovation systems, } \\
\text { new administrative city, } \\
\text { innovation city, enterprise city }\end{array}$ & $\begin{array}{l}\text { CR management } \\
\text { policy, five-year } \\
\text { BRDP, macro- } \\
\text { economic regions } \\
\text { and daily life-zones, } \\
\text { innovation cities } 2.0\end{array}$ \\
\hline $\begin{array}{l}\text { Institution } \\
\text { building } \\
\text { for regional } \\
\text { development }\end{array}$ & & & & $\begin{array}{l}\text { BN(R)DC (Balanced National } \\
\text { [or Regional] Committee), } \\
\text { special account for regional } \\
\text { development, regional } \\
\text { innovation councils }\end{array}$ & $\begin{array}{l}\text { BNDC or BRDC, } \\
\text { special account } \\
\text { for regional } \\
\text { development, block } \\
\text { grants }\end{array}$ \\
\hline
\end{tabular}

Source: Author. 
approach of European countries. However, some policy elements have remained in place for decades, despite changes of government. They are the growth restriction policy in the $\mathrm{CR}$, the industrial parks program, the regional industrial promotion program and the multifunctional administrative city and the innovation cities, even though the latter two are more recent interventions involving only minor changes in substance. Such consistency in the above policy elementswhether it has been maintained wittingly or unwittingly-has produced some tangible results. The discussion in the following sections attempts to sketch out a timeline of the major elements of Korea's regional policy.

During the early phase of economic development in Korea, regional policy was mainly geared toward the industrialization of the country. Hence, regional development was simply understood to involve building up industrial parks and complexes in the most appropriate locations. In other words, regions were not regarded as communities with any self-governing ability. Rather, they were simply treated as locations and sites for industrial development (OECD, 2012). "Industrial location policy" in the service of economic growth prevailed throughout the 1960s and 1970s and contributed greatly to the rapid industrial development of Korea. The efficiency principle-that is, choosing the best locations for the largest benefits-was largely observed until the late 1980s (Kim, 2012; Kim, 2010). Equity concerns, including regional imbalances, have occasionally arisen. For example, rural development policies-including the Saemaul Movement-were implemented to improve the living conditions in rural areas in the 1970s. Furthermore, during the 1980s, there were policy efforts to develop lagging regions, multiple-nuclei territory and regional living spheres (MLIT KRIHS, 2013). However, the overall development strategy before the 1990s followed the logic of "grow first, distribute later". Accordingly, regional policies during the early periods adopted the theory of growth poles, which involves the promotion of the selective development of regions with high growth potential. The trickle-down or spread effects the theory predicted did not materialize.

The top-down regional policies devised by the central government, even though they paid some attention to balanced regional development, did not mitigate regional disparities or enhance the growth potential of lagging regions. One exception was the policy of restricting the concentration of population and industries in the CR. However, this policy, which began in earnest in the 1980s, was defective in the sense that cities and regions outside of the CR were not ready to accept or cultivate those firms and people who had been deconcentrated from the CR. In short, spread or spillover effects, even if imposed by the government, did not happen immediately; they took a long time. Below, two types of policy responses to uneven growth will mainly be discussed. They are de-concentration and dispersion plus regional capacity enhancement policies.

\section{De-concentration}

Curbing population and industry concentration in the CR was the major concern in Korea in the 1970s and continued afterwards. It is perhaps the most elaborate 
policy program developed by the Korean government; however, it has generated dubious results (Choe and Kim, 2001). The central government introduced the First Capital Region Management Plan (1984-1996) to combat the concentration of population and economic activities in the CR, which was defined as including the jurisdiction of Seoul Special City, Incheon Metropolitan City and Gyeonggi Province. The primary objective of the plan was to promote the balanced development of national territory through control of the "over-concentrated" population and industries in the CR as well as the selective dispersion of functions away from the CR. Unique to Korea, national security was another reason for the plan. This region was subject to the Capital Region Management Law, which overrides all other laws related to development activities in the region. The major tools of the plan were laws and decrees regulating development activities inducing population concentration. The region was divided into five zones with varying degrees of development control. ${ }^{9}$ In addition to this broad zoning, three other policy instruments were adopted. They were congestion charges, aggregate development ceiling systems for factories and universities and differential tax treatments and levies. ${ }^{10}$

The Second Capital Region Management Plan (1996-2011) amended the five zones into three zones ${ }^{11}$ and continued to use physical regulations to suppress population-inducing activities. The plan adopted more market-type regulations instead of direct administrative measures so that some large-scale facilities could be built as long as congestion fees were paid. The government also took measures to increase tax breaks and financial support for the firms relocating from the CR to other regions. In the Third Capital Region Management Plan (2006-2020), regulations applying to the region have been rationalized, that is, excessively restrictive measures have been eased and more market-oriented measures have been introduced to soften physical and direct regulations to enhance national competitiveness in a globalized market (Lee, 2013; Kim, 2001.).

The primarily restrictive nature of the Capital Region Management Plans has led to them being criticized on the grounds that they have been ineffective in terms of dispersing population and industries away from the CR while at the same time creating unnecessarily high costs for firms and other economic entities to operate in the CR. ${ }^{12}$ However, the counterfactual situation in the absence of restrictive policies might have been far worse in terms of population and industrial activities concentration and the resultant living conditions, such as air pollution and traffic congestion in the CR (Choe and Kim, 2001; Lee, 2013). Given the almost impossible task of evaluating the costs and benefits of the programs related to the Capital Region Management Policy, subjective judgments are inevitable and they naturally differ between conservative and progressive analysts and among regions and localities. Conflicts between the CR and non-CR localities with respect to the de-concentration policy inevitably led politics to play a role in government decision-making. As the devolution of power from the center to the localities proceeds in Korea, de-concentration and associated balanced regional development policies are becoming a more political exercise based on populism rather than rational decision-making. Ultimately, 
policy decisions regarding balanced regional development boil down to the trade-off between efficiency and equity. The key lies in social consensus building and whether a society in a given time is willing to compromise and make tradeoffs in an acceptable manner.

One critical flaw in the de-concentration policy discussed above was insufficient preparations at the receiving end (non-CR regions) to entice industries and activities that contemplated moving away from the CR. The trend towards the concentration of talents and technology in the CR deepened in the 1990s and the 2000s, especially after the 1997 economic crisis, which accelerated the transition from an industrial into a knowledge-based economy. In recognition of this flaw in the regional policy, the central government began to pay attention to regional capacity enhancement through assisting regional innovation systems. However, the regional approach has still been top-down and focused on the dispersion of public and semi-public institutions rather than assisting the enhancement of the development potential of non-CR regions. This so-called "autonomous" regional development policy includes a special administrative city, innovative cities through the dispersion of public institutions and enterprise cities (a kind of public-private partnership).

\section{Dispersion plus regional capacity enbancement}

Regional capacity enhancement policies or programs began in earnest in the early 2000s, even though regional policies in previous periods discussed some components of regional capacity enhancement. For example, there were attempts to develop specialized regional industries, regional economic zones with hub cities and techno parks and R\&D centers in the late 1980s and 1990s. These attempts either fizzled out or were stopped due to changing domestic priorities and changes of government. A more systematic approach for regional capacity enhancement or autonomous regional development was taken in the early 2000s. It is notable that the government enacted a special law and installed a special account for balanced national development as well as a presidential committee for balanced national development and regional innovation councils in 2003 .

The regional policy undertaken by the Roh Moo-hyun administration (20032007) involved three elements: the dispersion of public agencies and institutions, the promotion of regional innovation capacity and decentralization (Kim, 2014). In relation to the former two elements, the policy devised four specific programs: (1) strategic new cities, such as a multifunctional administrative city, innovative cities and enterprise cities; (2) regional innovation system construction and regional industrial cluster development; (3) planned management of growth in the CR; and (4) development of lagging regions by building up infrastructure, innovation systems and the convergence of industries (Lee, 2005). In terms of policy substance, programs ( 1 ) and (2) are additions to previous regional policies. The details of these programs will be briefly discussed below. The multifunctional administrative city was proposed as a compromised version of the new administrative capital. ${ }^{13}$ The main idea behind it was that regional imbalances would be 
reduced by the relocation of government functions from Seoul to a location 120 $\mathrm{km}$ south. It was planned to be a self-sustained administrative city with a population of half a million by $2030 .^{14}$

Innovation cities were to be developed in local cities outside of the CR. Eleven cities were designated in order to develop local hubs for innovation activities. More than 100 public institutions were supposed to be dispersed among the ten innovation cities. They were distributed evenly across the regions outside of the CR. The physical construction of these innovation cities has been completed. ${ }^{15}$ As the government admits, these innovation cities are not ready to play a growth hub role in their respective regions, even though they were planned to be innovation hubs creating synergy effects by combining public institutions with enterprises and universities. In order to introduce cluster effects and thus local economic growth, it was deemed necessary to provide an appropriate business environment that included tax incentives and rent subsidies. Also required were local-level support systems for setting up ventures or new businesses. The biggest hurdles to enterprises moving into these innovation cities were known to be the lack of skilled labor and attractive living environments. Public institutions, even though they can contribute one-shot boosts, cannot play a leading role in the long-term cultivation and promotion of prosperous enterprises. Moreover, cooperation networks among public institutions, local universities and enterprises are insufficient to support integrated innovation clusters (Kwon, 2017; MLIT, 2018).

The idea of enterprise cities proposed by the Federation of Korean Industries was adopted as a part of the local development program. Private enterprises were supposed to build enterprise cities in underdeveloped regions with tax support and subsidies from the government. But the results are not promising. Four out of six districts that were designated for enterprise cities are still in progress and two have been cancelled. Out of those four, three are making some progress, while one shows a sluggish pace. The major hurdles that these enterprise cities are facing are competition arising from private development activities similar to those in the enterprise cities, insufficient demand for targeted activities and government regulations. ${ }^{16}$

In a strict sense, these new strategic city programs cannot be called "autonomous" regional development since they are fundamentally based on the dispersion of functions and institutions from the CR. Local and regional inputs are added on later with the support of the central government. Even though regional policy in the 2000s can be characterized as more place-oriented than the policies of the past, it was still far from a place-based policy utilizing "inhouse" potential and strength. Moreover, the effects of this autonomous regional development policy remain uncertain. In terms of transplanting public institutions and attaining target populations, this policy appears to have been a success; however, the enhancement of regional innovation capacity, the main goal of the policy, is yet to materialize (Kim et al., 2017; Joint Government Ministries, 2018). Autonomous regional development, loosely defined as a region's self-sufficiency in terms of capacity for development and renovation, 
requires a fiscal and planning power independent of the central government. Korea's trajectory shows that it has been moving toward devolution of power from the central to the local and regional authorities but that it still has a long way to go (Kim, 2014).

One component of regional policy that has been implemented since the late 1990s is the "regional industry promotion" program in the metropolitan cities and provinces outside the CR. ${ }^{17}$ There have been some additions and deletions over time. For example, regional innovation clusters and cross-regional cooperation programs were added and leading industry promotions for the macro-economic regions were deleted. The evolution of programs to develop regional industries for employment creation provides an interesting case for the design of regional development policies, showing how to bring in local resources and initiatives and how to set up cooperative inter-governmental relations. There are two drawbacks to this regional industry promotion program that place an emphasis on the development of specific industries: (1) fierce competition between regions to attract more or less the same fashionable industries; and (2) a tendency to ignore soft factors, such as quality of life, amenities and an institutional environment for long-term regional development.

One disruption in this policy shift from de-concentration to self-reliant regional development came with the 1997 economic crisis. This caused an urgent concern about national competitiveness, which naturally raised the issue of regional competitiveness as well as the appropriate scale of regions, that is, whether administrative regions or functional economic regions ought to cross the boundaries of administrative regions (Kim, 1998; Jang, 2011). While largely keeping the institutional structure of laws and committees for regional development, there was an attempt to redefine regions for sustainable development during the Lee Myung-bak administration. Instead of 16 administrative divisions of metropolitan cities and provinces, the administration proposed $5+2$ macroeconomic regions by grouping several cities and provinces. ${ }^{18}$ Meeting the viable regional size in a globalized economy, all of the five regions had above 5 million people and the national GRDP share of each region was above 10 percent. This redrawing of macro-economic regions was intended to improve regional competitiveness and thus to contribute to national competitiveness. To serve the goal of regional competitiveness, cooperation and integration between cities and provinces within each macro-economic region was emphasized, more or less following the World Bank's recommendations in the World Development Report of 2009. Each region was supposed to develop two leading (propulsive) industries suitable for the region. Furthermore, there were efforts to develop the science and technology capabilities of macro-economic regions in relation to selected leading industries by utilizing regional hub universities and public research institutes. To enhance physical integration between and within regions, various network infrastructures-including highways, railroads, airports and seaports-were planned. To carry out the strategy of competitive regional development, macro-economic region development committees and executive offices were established for them in all $5+2$ economic regions. ${ }^{19}$ 
As Korean society moved away from a focus on economic growth alone in the 2000s, popular demands for social equity, welfare and quality of life increased rapidly. Balanced regional development, representing one dimension of equity, became entangled with concerns over social equity and quality of life. Some argue that the national objective should be social equity rather than spatial equity and that regional policy should be designed around quality of life concerns, that is, the provision of public services and self-cultivation or life opportunities. Still others insist on a balanced regional development through decentralization and the reduction of regional disparities (Lee et al., 2018; Kim, 2010; Ahn et al., 2017). While debates over "efficiency versus equity" and "people versus place prosperity" remain unresolved, Korea has entered into a slow growth phase with the imminent prospect of a shrinking population, especially in small cities and rural areas, and an aging population in the 2010 s and beyond. New challenges have arisen for balanced regional development. More broadly, there is no social consensus in Korea about how to achieve equitable growth-that is, how to balance efficiency and equity-even though society in general seems to be inclined to place more weight on equity, primarily social equity and partly regional equity. Korea still faces the unresolved issue of how to achieve balanced development across the regions while maintaining sustainable economic growth. ${ }^{20}$ Balanced regional development, even though it is a worthwhile goal to pursue, needs to be redefined around more practical objectives such that all regions can sustain acceptable living standards while at the same time making efforts to utilize their development potential through expanding their human, social, cultural, environmental and physical assets.

Another contentious issue is whether a bottom-up approach is feasible and desirable given the low level of regional and local autonomy in Korea. Many argue for the decentralization of power to the regional and local level, while some worry about potential divergences in regional ability for autonomous development resulting in perhaps larger disparities between regions (Lee et al., 2018; Choi, 2017; Kim and Jin, 2006). Currently, most provinces and metropolitan cities-except for Seoul-lack the regional capacity to carry out their own development initiatives with sufficient resources. Hence, they are still dependent on the central government for resources. In consequence, national power elites are utilizing regional dependency on the central government for political gain. As a result, balanced development often amounts to a unitary distribution of resources across regions, creating inefficiency at the national level (Cha, 2017). Pork-barrel politics are also present in the allocation of these resources. The trend towards further decentralization appears to be on track; this, in theory, will help regions and localities to strengthen their ability to plan for and govern their regions. However, it would also complicate the politics surrounding regional development. Regions, even if they are in possession of more financial and policy power, may not take full responsibility for the results, given the inertia of dependency on the central government. Therefore, the devolution of power must be accompanied by regional accountability and monitoring by the central government (Lee et al., 2018; Ahn et al., 2017). 


\section{Summing up the Korean experience and implications for developing countries}

Among OECD countries, Korea has implemented a fairly extensive and diverse array of regional policies. The major thread of Korea's regional policy has been and still is redistribution or, more accurately, dispersion away from the CR, although regional capacity-building measures have been added in recent decades. Korea's de-concentration policy is perhaps the most elaborate in the world. The effectiveness and the benefits of the policy are, however, dubious. Policymakers in developing countries should keep one thing in mind: Balanced regional development cannot be attained simply through redistribution policies, as Korea has been doing with its policies encouraging or coercing enterprises and public institutions to move away from the leading region, that is, the CR. If convergence or balanced regional development is to be promoted, this must be done by promoting self-reliant regional development with some degree of regional autonomy and accountability. Nonetheless, even in the early stages of development, spatially targeted interventions and the provision of minimal standards across all regions are necessary for national integration. Such a need is perhaps more apparent in a democratic country with diverse regional constituencies, as the Korean case has demonstrated.

On the other hand, progress in self-reliant regional development, in spite of the diverse programs that have been implemented, is slow because of insufficient regional capability and weak self-governance. For self-reliant or autonomous regional development, capacity building at the local and regional levels is necessary, as recommended by the OECD (2012). The Korean experience suggests that it takes a long time for regions and localities to attain sufficient capacity to develop their own strategies and to then implement them using their own resources. Of course, local autonomy through the devolution of power from the central government would help develop such local capacity, but it does not guarantee equal performance across regions and localities. In fact, it might aggravate regional disparities, leading to the return of central government interventions. The building of local capacity itself then becomes another avenue for interregional competition as well as for central government manipulation.

The planning and implementation of Korea's regional policies can be summarized as top-down (even in an era of professed local autonomy). Moreover, policy implementation is still fragmented by diverse ministries (that is, insufficient coordination among the ministries, especially in regional innovation system-related projects). The Korean case, however, demonstrates the importance of policy consistency. Certain elements of regional policies-for example, the regional industry promotion program-have been maintained in spite of government changes and have produced some results. Another innovation cities program is expected to grow the innovative capacity of localities and regions if current efforts continue for the next decade. As the OECD (2012) stated in its report, political support and implementation on a multi-annual basis are essential to achieve the policy objectives of balanced regional development. 
In Korea, regional policy objectives have changed from de-concentration to disparity reduction, balanced regional development and sustainable regional development-but these are still clouded in obscurity. The efficiency-oriented industrial location policy of the early decades of development has contributed greatly to the rapid growth of the Korean economy. The resource allocation and planning system under a centralized and hierarchical governance system was effective in attaining economic growth but produced unbalanced regional growth and subsequently incurred heavy costs to ameliorate such imbalances. Nonetheless, Korea's industrial location policy, especially its industrial parks, could be an effective tool in early industrialization phases where agriculture and rural populations are dominant, as observed in countries such as Cambodia, Laos and Myanmar in Southeast Asia and in many countries in Africa. Longterm considerations are, however, necessary when implementing industrial development policies in order to prevent excessively heavy concentrations in single regions.

Achieving balanced regional development may not be the only goal for many developing countries. Therefore, balanced regional development should be weighed against other national objectives, such as economic growth and poverty reduction. This implies the need for a careful balancing of, ultimately, efficiency and equity. Agglomeration economies and economies of diversification still dominate the spatial development process in Korea. Fighting against market forces is very difficult and costly. Any country attempting to achieve balanced regional development must carry out a sort of cost-benefit analysis. These cost-benefit analyses might vary depending on a country's phase of development. For example, too early policy interventions would be a huge waste of resources necessary for national development. Excessively late interventions would also incur heavy costs. The rationale for balanced regional development might also differ depending on a country's political system, for example, whether it is unitary or federal. As the Korean case demonstrates, there is also a clear need for appropriate regional frames of development and a governance system including center-regional-local relations.

More fundamentally, the Korean case highlights a key question: What constitutes balanced regional development? It is obvious that balanced regional development in a market economy does not mean an equal distribution of population and economic activities or an equalization of economic performance across the regions. ${ }^{21}$ Therefore, the answer lies in acceptable levels of balanced or imbalanced regional development. Given the almost impossible task of quantifying acceptable levels of balanced regional development, most countries adopt spatial redistribution policies for territorial cohesion, similar to the case of income redistribution across different income classes for social cohesion. One critical drawback of such endeavors is the absence of social consensus and the accompanying rules of spatial redistribution. Furthermore, populism and pork-barrel politics tend to prevail in a democratic society. This tendency is more pronounced in a unitary government system than a federated government system. As a result, 
precious resources are often distributed without careful consideration of national efficiency loss and regional competitiveness gain (Lim, 2012; Cha, 2017).

Finally, one needs to take into account the pros and cons of both a place-based and place-neutral approach to regional development. Korea's trajectory indicates that the place-neutral approach (in effect until the 1990s) and the place-based approach (in ascendance since the 2000s) have, on the whole, mixed records of success and failure. The debate over these approaches essentially boils down to an efficiency versus equity trade-off (Jang, 2014; Kim, 2010). While the placeneutral approach advocated by the World Bank (2009) focuses more on social equity rather than spatial equity, the place-based approach advocated by the OECD (2009) adopts a different position, emphasizing places and the people living in them. In the OECD's approach, regional policies should be place-based and contingent on geographical context (Barca, McCann and Rodriguez-Pose, 2012). However, the effectiveness of a place-based approach depends on each country's politico-economic context as well as on certain preconditions, such as building regional institutions and cooperative inter-governmental relations. In reality, a country's choice will be neither fully place-based nor fully place-neutral. Depending on levels of development and institutional setting, countries will adopt a different mixes of both approaches. For example, a low-income country without natural resource endowments will need to pay more attention to efficient growth, which will largely involve the implementation of a place-neutral approach. By contrast, a middle-income country with a more or less diversified urban and regional system will benefit greatly by adopting a place-based approach. The size of a country also matters. A small country would not have a sufficient basis to pursue a broad-based approach-that is, to pursue more or less even growth across all regions to reap the benefits of a diversified regional economy. The Korean example demonstrates the dilemma of a medium-sized country seeking balanced regional development.

\section{Notes}

1 Kim (2014) discusses the evolution of Korea's regional policy from the two combined processes of economic development and democratic governance.

2 Wang-Bae Kim (2003b) pointed out that regional policies under the influence of political regionalism undermine national integration, rational judgement and a rational political culture.

3 The special issue of Korea Journal (volume 43, no. 2, 2003) discusses regionalism in Korea.

4 The fact that Chungnam recorded a positive gain in national population share indicates the effect of a new administrative city development begun in the 2000s.

5 This is clearly exceptional compared to other countries. Given the higher labor productivity in the CR, the average GRDP per capita in the CR suggests that population increase in the CR has erased labor productivity advantage in the CR. However, when per capita income tax instead of per capita GRDP is used, Seoul is much higher than other regions (Kim, W.B. 2003a). 


\section{Won Bae Kim}

6 The OECD Regions and Cities at a Glance 2018 report maps out regional disparities in GDP per capita in terms of OECD countries. Korea belongs to the middle group, having less regional disparities than Great Britain, the USA, Germany, France, Switzerland, the Netherlands, and so on.

7 It should be noted that Daejeon's high share of R\&D personnel is also the result of the establishment of the Daedeok Science Park, the development of which began in the early 1970s and was completed in the early 1990s.

8 This is a well-known convergence hypothesis proposed by Williamson (1965). However, this convergence process is affected by country contexts including a political system, that is, whether a country has a unitary or federated system (Henderson, 1988).

9 The five zones are the relocation promotion zone, the limited redevelopment zone, the development reservation zone, the development promotion zone and the nature preservation zone.

10 See the KRIHS publication PKPP 2013-2014 by Lee (2013) for the details of the policy.

11 These three zones are the growth management zone, the nature preservation zone and the development control zone.

12 There have also been conflicts between the central government, on the one hand, and local authorities and the private sector, on the other, with respect to the restrictive measures, thus creating a governance problem for the CR (Kim, 1999).

13 It began as an idea to relocate the Korean capital but moving the capital from Seoul was ruled unconstitutional in 2004.

14 Later the city was named Sejong Special City.

15 As of late 2018, ten innovation cities have been completed and 115 public institutions have been relocated. As of June 2018, the population in these innovation cities grew to 182,000 and the number of enterprises that moved in reached 639. However, the majority $(67.4 \%)$ of the 639 enterprises moved into the innovation districts within large metropolises such as Busan, Daegu and Gwangju.Jeonnam, while only 6.7\% moved to Jeonbuk, Gyeongbuk, Chungbuk and Jeju. Out of 639 enterprises, 177 relocated from the SCR and 326 moved from within the same province. Only five of them have more than 300 employees, while the majority of them (552) are small-size enterprises with less than 30 employees (Joint Government Ministries, August 27, 2018).

16 Details on the progress and limitations of the enterprise cities are discussed in Kim and Shin (2013).

17 The regional industry promotion program began to be implemented in the late 1990s. At first, specialized industries for four metropolitan cities and provinces (footwear for Busan, textiles for Daegu, optical industries for Gwangju, and machinery for Gyeongnam) were promoted. Then the program expanded to $4+9$ provinces. The name and emphasis have changed over time. Over this period, the scale of regions covered mostly cities, counties and provinces. From 2008 to 2012, the macroeconomic regions were expanded (Regional Development Committee, 2017: 2). In essence, the central government attempted to develop region-specific industries that had at least some existing regional industrial bases and growth potential. In later periods, new industries suitable for each region were added. The most recent details of the program are summarized in the press release by the Ministry of Industry and Commerce and the Ministry of SMEs and Startups (December 27, 2018).

18 The five major macro-economic regions were CR (Seoul, Incheon, Gyeonggi), SCR (Busan, Ulsan, and Gyeongnam), Chungcheong Region (Chungcheongbuk 
and Chungcheongnam), Honam Region (Gwangju, Jeonnam and Jeonbuk) and Daegyeong Region (Daegu and Gyeongbuk). The two provinces of Gangwon and Jeju were separated due to their isolated location, even though their size is small compared to the five main regions.

19 In order to supplement the macro-economic regions, the daily living sphere development plan was drawn to provide minimum public services to all the residents in the country (Jang, 2009). However, in the next administration (the Park Geun-hye government, 2013-2017), the scale of the regions was changed back to a smaller scale to meet the demands of people for quality of life. The concept of regional happy living zones was introduced instead of macro-economic regions. The current government has returned to the main administrative division between metropolitan cities and provinces, scrapping the ideas of macroeconomic regions and smaller-scale daily living zones.

20 The KRIHS report written by Ahn and others (2017) pointed out the lack of roadmap in Korea's regional policy, that is, how and to what extent regional disparities should be reduced in a given period of time. Instead, the policy focused on industrial promotion in the non-CR and assistance to lagging regions.

21 An alternative has been suggested to provide a national minimum level of living standards or life capacities across the regions instead of reducing the absolute gap between regions (Koo, Kim, and Yoon, 2012).

\section{References}

Ahn, H., A. Hong-gi, S. Kim, M.-Y. Lee, S.-J. Ha, S. H. Hong and D. Kim (2017). Toward Balanced Regional Development in the Low-growth Era: Issues and Policy Implications. Sejong: KRIHS (in Korean).

Barca, F., P. McCann and A. Rodriguez-Pose (2012). "The Case for Regional Development Intervention: Place-based Versus Place-neutral Approaches," Journal of Regional Science 52(1), pp. 134-152.

Cha, J. (2017). "Evaluation of Balanced Development Policies in Former Governments: From Park Chung-hee Government to Park Geun-hye Government," Social Science Studies 25(2), pp. 130-174 (in Korean).

Choe, S. (2014). "A Preliminary History of Regional Policies in Korea: 1960-1980 (I),” The Korea Journal of Regional Policy 1(2), pp. 1-16 (in Korean).

Choe, S. (2015). "A Preliminary History of Regional Policies in Korea: 1980-2000 (II)," The Korea Journal of Regional Policy 2(2), pp. 109-127 (in Korean).

Choe, S. (2016). "A Preliminary History of Regional Policies in Korea: 2001-2016 (III)," The Korea Journal of Regional Policy 3(2), pp. 217-239 (in Korean).

Choe, S. and W. Kim (2001). "Globalization and Urbanization in the Republic of Korea," in S. Yusuf, S. Evenett and W. Wu (eds.), Facets of Globalization, World bank Discussion Paper. Washington, DC: World Bank, 415.

Choi, H. (2017). Balanced Development and Decentralization Policy in South Korea. Case Studies on Public Policy in Korea for Knowledge Sharing. Sejong: KDI.

Henderson, J. V. (1988). Urban Development: Theory, Fact and Illusion. New York: Oxford University Press.

Jang, J. (2009). "Regional Development Policy in Korea: Past, Present, and Future," Journal of the Economic Geographical Society of Korea 12(4), pp. 576-596. 
Jang, J. (2011). "Regional Development Policy in Korea-Past, Present and Future," Journal of the Economic Geographical Society of Korea 12(4), pp. 576-596.

Jang, J. (2014). "Rationale of Regional Policy and Paradigm," The Korea Journal of Regional Policy 1(1), pp. 1-15 (in Korean).

Joh, J., Y. Kim and Y. Koh (2010). "Territorial Development Policy," in I. Sakong and Y. Koh (eds.), The Korean Economy: Six Decades of Growth and Development. Sejong: KDI, pp. 177-226.

Joint Ministries of Government (August 28, 2018). Enterprises Establishment in the Innovation Cities and Venture Promotion Measures (in Korean).

Kim, D. and Y. Koh (2010). "Korea's Industrial Development," in I. Sakong and Y. Koh (eds.), The Korean Economy: Six Decades of Growth and Development. Sejong: KDI, pp. 83-122.

Kim, J., W. Jeong, J. Song and K. Nahm (2017). Policy Directions for Revitalizing Innovation City in the 2nd Stage. Sejong: KRIHS (in Korean).

Kim, K. (2010). "Reconsidering the Goal and Strategy of Regional Development Policy in Korea," KDI Journal of Economic Policy 32(1), pp. 69-96.

Kim, S. (2014). "Regional Policy and National Development in Korea," The Korea Journal of Policy Studies 29(1): 101-122.

Kim, S. and Y. Jin (2006). "A Study on Decentralized Regional Development System: A Political Economic Analysis," The Korea Spatial Planning Review 49, pp. 55-76 (in Korean).

Kim, W. B. (1998). "Regional Development Policies in the Republic of Korea," Regional Development Dialogue 19(2), pp. 122-134.

Kim, W. B. (1999). "National Competitiveness and Governance of Seoul, Korea," in F. John (ed.), Urban and Regional Governance in the Asia Pacific. Vancouver: Institute of Asian Research, the University of British Columbia, pp. 33-50.

Kim, W. B. (2001). "Repositioning of City-regions: Korea After the Crisis," in A. J. Scott (ed.), Global City-regions Trends, Theory and Policy. Oxford: Oxford University Press, pp. 263-281.

Kim, W. B. (2003a). "The Evolution of Regional Disparities in Korea," Korea Journal $43(2)$, pp. $55-80$.

Kim, W. B. (2003b). "Regionalism: Its Origins and Substance with Competition and Exclusion," Korea Journal 43(2), pp. 5-31.

Kim, W. B. (2012). Korea's Industrialization and Urbanization: Processes and Policies. Unpublished manuscript.

Kim, W. B. and H. Shin (2013). "Economic Crisis and Regional Resilience in Korea," The Korea Spatial Planning Review 79, pp. 3-21 (in Korean).

Kim, Y. and S. Lee (2010). "Analysis of Inter-regional Growth Differentials and Policy Implications," e-KIET, 481 (2010-13) (in Korean).

Koo, G., S. Kim and J. Yoon (2012). "Regional Disparity and Regional Policy: Capability of Life Approach," Korean Public Administration Review 46(3), pp. 173-192 (in Korean).

Kwon, Y. (April 14, 2017). Progress of Innovation Cities and Future Tasks. Sejong: Joint Workshop on Regional Growth Hub Strategy Utilizing Innovation Cities (in Korean).

Lee, W. (2005). "Assessment of Balanced National Development Policy and Future Tasks," Planning and Policy 290, pp. 59-67 (in Korean).

Lee, W. (2013). Growth Management of the Capital Region. A Primer on Korean Planning and Policy. PKPP 2013-14. Sejong: KRIHS.

Lee, W., J. Yang, T. Park and J. Kim (2018). A Study on the Strategies for Decentralization of Balanced National Development Policies. Sejong: KRIHS (in Korean). 
Lim, H. (2012). "Paradigm Shift in Korea's Regional Development," Korea Regional Development Association Spring Symposium DanKook University Jookjeon Campus, June 2 (in Korean).

Ministry of Industry and Ministry of Small and Medium Enterprises (December 27, 2018). Press Release: "Run Together for Revitalizing Community Economy" (in Korean).

Ministry of Land and Transportation (October 25, 2018). Comprehensive Plan for the Development of Innovation Cities (Proposal) (in Korean).

MLIT and KRIHS (Ministry of Land, Infrastructure and Transportation and Korea Research Institute for Human Settlements, 2013). 2012 Modularization of Korea's Development Experience National Territorial and Regional Development Policy: Focusing on Comprehensive National Territorial Plan.

Moon, J., J. H. Moon, E. G. Jang, J. H. Park and M. J. Kang (2013). National Territorial and Regional Development Policy: Focusing on Comprehensive National Territorial Plan. In: 2012 Modularization of Korea's Development Experience. Ministry of Land, Infrastructure and Transport \& Korea Research Institute for Human Settlements. Sejong: KDI.

OECD (2007). OECD Economic Surveys KOREA. Paris: OECD.

OECD (2009). How Regions Grow. Paris: OECD.

OECD (2012). Industrial Policy and Territorial Development: Lessons from Korea. Development Centre Studies. Paris: OECD.

OECD (2018). OECD Regions and Cities at a Glance. Paris: OECD.

Oh, S. and S. Sohn (2017). "The Fourth Industrial Revolution and the Smart Regional Development Strategy," KISTEP InI 21, pp. 35-47. (in Korean).

Oh, Y., Y.-S. Oh, W.-G. Kim, I.-C. Kim and H.-k. Min (2009). Strategies for Industrial Upgrading to Expand the Growth Potential After the Global Economic Crisis. Sejong: Korea Institute of Industrial Economics and Trade (in Korean).

Regional Development Committee (February 2017). Promotion of Regional Industries and Analysis of Employment Creation (in Korean).

Ryu, S. (2018). "50 Years of Industrial Park Development: Results and Tasks," KRIHS Policy Brief No. 686 (in Korean).

Sakong, I. and Y. Koh (eds) (2010). The Korean Economy: Six Decades of Growth and Development. The Committee for the Sixty-Year History of the Korean Economy. Korea Development Institute.

Sonn, H. (2003). "Regional Cleavage in Korean Politics and Elections," Korea Journal $43(2)$, pp. 32-54.

Williamson, J. B. (1965). "Regional Inequality and the Process of National Development: A Description of the Patterns," Economic Development and Cultural Change 13, pp. $3-45$.

World Bank (2009). World Development Report. Reshaping Economic Geography. Washington, DC: World Bank. 


\title{
4 Urban transformation "Korean style" \\ Lessons from property-based urban development
}

\author{
Hyun Bang Shin
}

\section{Introduction}

In her observations of the emergent trend in Africa to produce blueprints of futuristic cities, Vanessa Watson (2014: 215) examines how African governments are keen to work with international investors to turn existing urban centers or peripheries into "gateways for international investors and showpieces for ambitious politicians". The efforts of the African cities can also be witnessed in other parts of the world-for example, in Southeast Asia, where governments have engaged in megaprojects to build brand new urban centers in peri-urban areas (see, e.g., Percival and Waley, 2012). One of the reasons behind this is the urgent need to address extant urban problems in the context of global competition for footloose capital while ensuring the legitimacy of incumbent political elites. In this global endeavor, Asian urbanism has emerged as a source of inspiration (Roy and Ong, 2011).

In this regard, South Korea (hereafter Korea) provides an interesting point of reference for cities elsewhere in the Global South. Cities in Korea are often depicted as vertical cities with endless clusters of high-rise condominiums and office buildings, supported by the seamless connectivities and mobilities of data, people and commodities. For onlookers, Korea's experience in transforming its urban-scape "from hovels to highrises" (cf. Power, 1993) may be received with a sense of wonder, an urban manifestation of Korea's "economic miracle" that has become a source of developmental aspiration. The Korean version of Asian urbanism, be it real or imagined (Shin, 2019), has been increasingly utilized by the Korean state and its agencies-such as the Korea Land and Housing Corporation-as an export to other countries in the Global South (see Jung, 2019; Kim, 2018; Lee, 2015; van Noorloos and Leung, 2017).

However, there is a danger of idealizing the developmental achievements of Korea when specific policies and projects are isolated from the sociopolitical relations that gave rise to them. In this regard, this chapter aims to highlight the importance of situating this developmental experience within Korea's broader sociopolitical relations while avoiding the risk of falling into "methodological 
nationalism" (see Choi, 2014; Doucette and Park, 2019). ${ }^{1}$ Lessons to be learned will have to involve a careful analysis of how Korea's urban development experience-which has relied heavily on accumulating property assets-came about and what this experience means for social equity and justice from a critical perspective.

The rest of the chapter is divided into four sections. First, it will discuss the post-war challenges and some of the noteworthy urban development experiments before the 1980s, when the country was prioritizing industrialization over the adequate provision of housing. Second, the salient characteristics of propertybased urban development from the 1980s onward will be examined, focusing on (1) the speculative nature of urban development, (2) rent gap and development gains, (3) vertical accumulation, and (4) displacement and dispossession of extant land users. Third, the role of the state will be analyzed, examining the extent to which the state endeavored to establish property as hegemonic. The final section will summarize the discussions and present lessons for urban development "Korean style" for other countries in the Global South.

\section{Pre-1980s urban development: post-war challenges and experiments}

The reality of urban development in Korea before the 1980s was that the private sector was weak-albeit on the path to realizing an economy of scale-and the level of housing investment stayed relatively low despite government emphasis on increased production. According to a report from the Korea Research Institute for Human Settlements (1981: 13-14), the share of housing investment in gross national product averaged 1.6 percent between 1962 and 1966 and below 3 percent between 1967 and 1971. In the 1960s, the housing supply in Korea was dominated by small-scale private builders who produced nearly 90 percent of new housing (Korea National Housing Corporation, 2001: 232). The Korea National Housing Corporation (hereafter KNHC), a public housing agency, was established in 1962 to build homes for low-income families nationwide; however, its contribution remained minimal during the early years (ibid.). The central government's attempts to increase housing production were often overly ambitious and its projections underachieved. For instance, the second five-year economic development program (1967-1971) aimed at the construction of 800,000 dwelling units, which was roughly equal to one-fifth of the total number of existing dwellings in 1965 (Ministry of Construction and Transportation of Korea, 2002: 27; Planning and Coordination for the Cabinet Office, 1967: 397). Once put into the implementation stage, the plan was substantially scaled down to aim for 500,000 units in order to save the government from humiliation (Ministry of Construction and Transportation of Korea, 2002: 27).

One of the key urban problems was sprawling illegal dwellings of poor quality. During the years of recovery after the Korean War (1950-1953), illegal and substandard dwellings sprung up in large numbers on available land in urban areas. This phenomenon was particularly acute in Seoul, Korea's capital. The Seoul 
Municipal Government largely regarded these dwellings as "cancerous elements" that deterred "continuous implementation of capital building" (Seoul Municipal Government, 1970: 263) or as undesirable features that "damaged urban landscape" (Seoul Municipal Government, 1973: 4). Policy responses in the 1950s and 1960s were mostly focused on containing their growth and demolishing existing illegal, poor quality dwellings. A report stated that, between 1958 and 1972, the municipal government managed to relocate approximately 0.3 million residents from 48,718 dwellings to the city outskirts (Jeong, 1984, cited in Jang, 1998: 27). Disciplinary measures were announced occasionally to discourage additional construction of such dwellings. For instance, right after the military coup in 1961, the owners of illegal dwellings subject to demolition were to be put on trial in a military court (see Kim et al., 1996: 74). However, clearing all the substandard neighborhoods with illegal dwellings posed various constraints and faced resistance, and many of them managed to survive.

In light of the difficulties in dealing with mushrooming illegal dwellings in Seoul, the municipal government made a proposal to the central government for the enactment of a special law enabling the municipal government to take more systematic measures to eradicate illegal dwellings and settlements. The Temporary Act on the Promotion of Housing Improvement (hereafter the Temporary Act) was thus enacted in 1973. It aimed at completing the "improvement" of all illegal and substandard dwellings by 1981, which was the year the Temporary Act was due to expire. The key to achieving this goal was to allow the free transfer of ownership of those public lands occupied by squatter dwellers from the central government to the municipal government. In this way, when an illegal settlement on such public land became subject to renewal, land sale revenues could be retained by the municipality, providing it with the financial resources to proceed with the subsequent renewal of other settlements (Kim et al., 1996: 85). The ideas behind the Temporary Act can be seen in the administrative statement by the Seoul Municipal Government below (Seoul Municipal Government, 1974: 331):

What is urgent in reality is to tackle the illegal, substandard dwellings that exist in disorder in great numbers all around the city ... these dwellings impoverish mountains and fields; cause inundation of rivers and flooding of urban districts; make citizens sick due to the pollution from contamination; cause low self-esteem that produce social problems as there are no benefits of having cultural facilities; and degrade the façade of Seoul. [Therefore,] it is inevitable to improve these illegal dwellings and put them in order.

The Temporary Act ultimately targeted approximately 121,000 dwellings in 230 project areas in Seoul, which accounted for about three-quarters of the 155,467 illegal dwellings identified in December 1973 (Seoul Municipal Government, 1974: 345-346). Any units excluded from this renewal measure were subject to demolition (Kim et al., 1996: 86). The main renewal method adopted was self-help renewal by means of either "in situ upgrading" or "clearance 
and redevelopment", depending on site conditions. The "in situ upgrading" scheme was not popular due to the financial burden, as it depended on owneroccupiers taking the initiative and paying for the expenses of upgrading their dwellings to the standard prescribed by the Building Act (Kim et al., 1996; Lee, 2000). The lack of meaningful progress was the same for the "clearance and redevelopment" scheme. However, this scheme is noteworthy for its laying out of the basic principles that the more commercially oriented urban redevelopment scheme from the 1980s (known as the Joint Redevelopment Program, or Hapdong Jaegaebal in Korean) was founded upon. ${ }^{2}$

The efforts by the Korean state to clear shanty settlements were structurally constrained as well. While the rebirth of the city center was essential for the authoritarian developmental state to demonstrate its power (e.g., the clearance of substandard dwellings along the Cheonggye Stream), substandard settlements located away from the new central business district survived the clearance efforts of the government, serving the function of providing affordable housing for the urban poor and keeping their labor costs low (Mobrand, 2008; see also Kim, 2010). Maintaining such living conditions for labor also met the interests of both the state and nascent capitalists because the state concentrated available resources on nurturing the growth of capital (especially the emergent conglomerates known as chaebol) that depended heavily on low wages and a large pool of surplus labor (Park, 1998).

The relatively weak emphasis on housing investment is reflected in macroeconomic statistics as well. When the Korean economy began to take off in the 1970s, gross investment in fixed capital formation expanded sharply to support Korea's industrialization. The value of gross fixed capital formation as a share of gross domestic product (hereafter GDP) at 2000 constant prices increased from 14.9 percent in 1970 to 26.1 percent in 1985 , hitting a ceiling of 39.3 percent in 1996 (The Bank of Korea, 2004). The absolute amount of housing investment increased in line with the expansion of investment in fixed capital; however, the share of housing investment in real GDP hardly exceeded the 5 percent threshold level between 1970 and 1985 (ibid.). In other words, housing investment received less emphasis in comparison with other investments in facilities and non-residential construction in times of rapid economic development.

\section{Post-1980s property-based urban development}

The urban policy of the Korean developmental state took a major turn in the 1980s, building upon the lessons from the previous era. The state proceeded with mass housing provision based on "bricks and mortar" subsidies to private builders; they also stipulated various laws to support the intervention by state agencies and property owners in land and housing development. The central government led by the December 1979 coup leader made a bold announcement in August 1980 that it would construct 5 million dwellings during the next ten years (Dong'a Ilbo, 1980; see also Son, 2000). Pursuit of this goal may have appeared quite mad, as it more or less equated with the total number of housing 


\section{Hyun Bang Shin}

stocks nationwide in 1980 and twice the total number of urban housing stocks (Economic Planning Board of Korea, 1982). The Korean state managed to boost housing production substantially throughout the 1980s by supporting private builders, many of which were subsidiaries of conglomerates, to increase their outputs. The total number of dwellings constructed between 1982 and 1992 reached about 4.1 million units (Korea National Housing Corporation, 2004; Ministry of Construction and Transportation of Korea, 2002). Between 1988 and 1992, 2.7 million of these units were produced (ibid.), assisted by another big push from the central government, which was led by the successor of the aforementioned coup leader.

The enactment of the Housing Site Development Promotion Act in 1980 also enabled the use of state agencies such as the Korea Land Corporation to develop land in urban peripheries and rural areas that could then be used for mass housing construction by builders (see the chapter in this volume by Im Seowhan). In Seoul, where the most crowded living conditions were amplified by the large presence of substandard settlements, urban redevelopment projects were launched to replace such settlements with high-density apartment complexes (Kim, 2010). In contrast, the strengthening of social welfare received much less attention throughout the 1980s and 1990s. It was only from the late 1990s, after the Asian financial crisis, that the Korean developmental state began to embark on initiatives to put together programs to build social safety nets and expand social housing programs (Song, 2009). Urban development in Korea from the 1980s can be summed up as property-based development that aimed at the physical improvement of the built environment for profitable gains. It exhibited the following key characteristics.

\section{Speculative urbanization}

The construction of an urbanizing society in Korea was initially led by the economic motifs of the Korean developmental state, which prioritized economic growth and industrialization. After a brief moment of import substitution, the authoritarian developmental state led by the military dictatorship pursued an export-oriented economy, investing in the formation of industrial clusters (Castells, 1992). A number of select small towns and cities across the country, such as Ulsan, Changwon, and Gumi, emerged as sites of concentrated investment to develop and expand manufacturing capacity, working in multi-scalar processes that brought together state actors as well as those in localities (e.g., on Changwon, see Choi, 2014). Infrastructural development as productive investment to support the growth of these industrial clusters also took place, rapidly giving rise to the accumulation of fixed assets (Harvey, 1978). In this regard, the 1960s and 1970s can be considered as a period of industrialization leading to urbanization (Shin, 2018). The opening of Korea's first expresswaythe Gyeongbu Expressway-to connect the southern port city of Busan with Seoul might be one of the best demonstrations of such fixed asset accumulation coordinated by the developmental state (Choi, 2010). 
However, the 1980s onward saw the rising importance of speculative urbanization that built on the growth and commodification of land and housing development (La Grange and Jung, 2004; Shin, 2009) as the main locus of wealth accumulation by real estate businesses as well as urbanites, especially the upperclass and emergent middle-class families. One of the key strategies pursued in this regard was the promotion of large-scale residential estates called danji, which allowed cost-efficient infrastructure provision and the standardization of condominium construction. Initially applied to the massive housing site development in the south of the Han River, the concept was developed to facilitate the ten-year (1972-1981) housing construction program (Planning and Coordination for the Cabinet Office, 1972: 253-254) and was subsequently supported by the aforementioned Housing Site Development Promotion Act. One of the most wellknown danji was the Mokdong danji, which accommodated about 27,000 units, geared largely towards emergent middle-class families (Shin and Kim, 2016: 545; see also Lett, 1998: 115-117; Son, 2000). The danji model has become the norm for new town programs as well as commercialized inner-city redevelopment programs, both of which were embarked upon from the 1980s.

The Korean developmental state in the late 1980s embarked on the construction of new residential towns; this was in sharp contrast to its practice of building new industrial towns throughout the 1960s and 1970s. The five new towns constructed between 1989 and 1996 included Bundang, Ilsan, Pyeongchon, Sanbon and Jungdong, all located on the peripheries of Seoul and thereby serving as "bed towns" for middle-class families whose breadwinners largely commuted to Seoul (La Grange and Jung, 2004). The Housing Site Development Promotion Act was instrumental in the construction of these new towns, with the Korea Land Corporation acing as developer of all new towns except Jungdong, which involved the KNHC and Bucheon Municipal Government as the other two developers. Development gains were anticipated by the Korea Land Corporation, which sold assembled land to private builders, who subsequently constructed commercial condominiums for profit. Through the Housing Site Development Promotion Act, the Korean developmental state was able to fast-track planning and construction processes.

Speculation was a frequent source of concern in the housing market. Condominiums were particularly attractive to the emergent middle class from the late 1970s (Gelézeau, 2007; Yang, 2018). Middle-class buyers rushed in and snatched up condominium units supplied in large numbers in the south of the Han River in Seoul, commonly referred to as Gangnam. Living in an apartment complex came to be regarded as a key status symbol, as Lett (1998: 110) notes: "The stereotypic image of South Korea's contemporary middle class included not only residence in Kangnam [Gangnam] south of the Han River but also life in a highrise apartment complex". Various reports suggest that new condominium units in new apartment complexes (danji) became the object of intense competition among buyers. For instance, in 1977, 19,800 applications were reported to have been made for 160 new units put up for sale, creating rampant speculative fervor among buyers (see Mobrand, 2008: 381-382). 
Condominiums produced as a result of commercial urban redevelopment were particularly attractive to middle-class speculative buyers because these units were supplied at production cost for the original property owners with little profits imposed by developers ( $\mathrm{Ha}, 2001)$. Typically, financially weak property owners sold their rights to these newly redeveloped condominium units to speculative buyers, while developers enjoyed profits from selling excess redeveloped units supplied through high-density development (Shin, 2009). Such units supplied at production cost caused a large price increase in the market, allowing buyers to reap their own returns on speculative investments.

\section{Rent gap and development gains}

As Harvey notes, "land is not a commodity in the ordinary sense. It is a fictitious form of capital that derives from expectations of future rents" (2012: 28). When a piece of land gets (re)developed, the completion of development can be equated with the closure of the rent gap between capitalized ("actually realised") land rent based on the extant use of the land and potential land rent that is expected when the land is put to "the highest and best use" (Clark, 1988; Smith, 1979). A number of factors contribute to the rise of a rent gap. It can be created "by continued urban development and expansion ... that has historically raised the potential ground rent level in the inner city" (Smith, 1996: 67-68)-though there is no reason to assume that this would happen only to inner-city areas (see Lees, Shin and López-Morales, 2016). In a country such as Korea that has experienced condensed urbanization and heavy investment in fixed assets, including infrastructure (Shin, 2019), the potential land rent in underdeveloped land in urban peripheries or former agricultural areas would experience a rapid increase, raising expectations for ample development gains when such land is designated for (re)development. This process of rent gap closure through (re) development would underlie the state-led development of new housing sites as per the Housing Site Development Promotion Act.

The urban redevelopment of substandard settlements in Seoul is an example of how the rent gap drives commercial property-based development. Here, the rent gap may have grown by a number of factors, some of which I will outline here. First, as noted above, city-wide development in Seoul places development pressure on existing substandard settlements in order to put the land to "the highest and best use", such as condominium estates for more affluent families or office buildings for businesses. Second, rent gaps may also be enlarged by changes to the planning regulations that affect substandard settlements. For instance, higher building density permitted to a parcel of development land would increase the potential land rent. Changing the land use designation into something that allows for more profitable development (e.g., agricultural use converted to urban residential use) would also create a larger rent gap and thereby greater development pressure. Third, as property owners in substandard settlements usually face a lack of de jure property rights due to the illegal status of their properties standing on public land, ${ }^{3}$ property owners and particularly absentee landlords would have less 
incentive to make substantial reinvestment in their properties; this would lead to the devaluation of their properties and subsequently lower capitalized land rent. Furthermore, if a neighborhood is designated as a redevelopment district, additional structural extension or modification of the dwellings would be prohibited in accordance with the Urban Planning Act until the commencement of redevelopment (Ministry of Construction and Transportation of Korea, 2000: 40-41). ${ }^{4}$ This would force property owners to "keep the building appropriate to its site, or, withhold investment, minimize maintenance and variable costs, and milk it as it stands, resulting in a broadening of the rent gap" (Clark, 1988: 252); it would also discourage inward investment even more, thereby keeping the capitalized land rent at low levels and enlarging the rent gap.

If we take the increase in land price as a proxy to understand the extent of rent gap closure, redevelopment of dilapidated neighborhoods should result in ample profiteering opportunities, especially when much of the land in such neighborhoods is not privately owned. According to a report from the Seoul Municipal Government in 1998, about 40 percent of the land in redevelopment project neighborhoods in Seoul was in public ownership, while 57 percent of dwellings were without land titles and thus illegal (Seoul Municipal Government, 1998: 20-21, cited in Shin, 2009: 908). As the high share of public land and illegal dwellings commanded lower land prices, redevelopment projects aimed at privatizing public land and commercial high-density developments led to the surge of (official) land prices. For example, in Sanggye 4-1 District-which was located in northeastern Seoul and was one of the first redevelopment project sites completed just before the 1988 Seoul Summer Olympic Games-the purchase price of public land was KRW 90,750 per square meter, which was only half the price of the private land in the adjacent neighborhood (Jang, 1998: 58-59).

Nevertheless, when news of (re)development spreads, there is a growing expectation that development gains can be made, attracting speculative interests who would exploit the opportunity by, for example, purchasing extant properties at higher prices to win the right to become a member of the redevelopment association, entitling them to purchase a redeveloped unit at a discounted price. Such speculative activities lead to the rise of capitalized land rent. As Clark notes, "[c]apitalized land rent rises rapidly, and the rent gap narrows rapidly, towards the end of the cycle when the property becomes an object of speculation with a view towards redevelopment" (1988: 252). Korea has seen many such speculative interests in the process of promoting urban redevelopment as well as housing site development.

Furthermore, the profit-oriented nature of urban redevelopment can also be seen in the way project financing hinges on maximizing the production of commercial units for sale. This is because the size of profits for redevelopment associations are determined by the number of new units sold in the new housing market. ${ }^{5}$ According to data released by the Ministry of Land, Infrastructure and Transport, ${ }^{6}$ there were, in total, 547 redevelopment districts designated between 1972 and 2004 in Korea, which were to produce nearly 300,000 new flats. Of these, only 6.4 percent were allocated to the members of the redevelopment 
Table 4.1 Distribution of redevelopment flats per use in designated redevelopment districts in Korea

\begin{tabular}{|c|c|c|c|c|c|c|}
\hline \multirow[t]{2}{*}{ Year } & \multirow{2}{*}{$\begin{array}{l}\text { Designated } \\
\text { Redevelop- } \\
\text { ment } \\
\text { Districts, } \\
\text { (A) }\end{array}$} & \multicolumn{4}{|c|}{ Number of New Flats } & \multirow{2}{*}{$\begin{array}{l}\text { Average } \\
\text { Number } \\
\text { of Flats } \\
\text { per } \\
\text { District, } \\
B / A\end{array}$} \\
\hline & & $\begin{array}{l}\text { Sub-total } \\
\text { (B) }\end{array}$ & $\begin{array}{l}\text { Redevelopment } \\
\text { Association } \\
\text { Members }\end{array}$ & $\begin{array}{l}\text { For Commercial } \\
\text { Sales }\end{array}$ & Public Rental & \\
\hline 1972 2004 & 547 & 294,166 & $18,942 \quad 6.4 \%$ & $228,707 \quad 77.7 \%$ & $46,517 \quad 15.8 \%$ & 538 \\
\hline 2005-2017 & 972 & 922,535 & $411,758 \quad 44.6 \%$ & $410,452 \quad 44.5 \%$ & $100,325 \quad 10.9 \%$ & 949 \\
\hline
\end{tabular}

Source: MOLIT Statistics System. URL: http://stat.molit.go.kr/

association that led the redevelopment, while 77.7 percent were produced for sale in the new housing market (see Table 4.1).

\section{"Vertical accumulation" and the vertical city}

Maximizing development gains and returns on investment can be aided by building densification as a key planning tool. One way to judge the degree of densification is to examine the floor-area ratio (hereafter FAR), which is the ratio of a building's gross floor space to the net area of the ground where the building stands. FAR has been an effective planning tool for the government in propelling or restraining real estate development: A high FAR would incentivize real estate investors, as a larger building volume for sale can be provided on the planned site, whereas a low FAR would have the opposite effect. The case of urban redevelopment summarized in Table 4.1 also illustrates the importance of density for commercial gains. Between 2005 and 2017, the average share of redeveloped flats for sale in the new housing market decreased to 44.5 percent, which translated to lower profitability than in previous years. However, this was compensated for by higher density development: The average number of redeveloped flats per district between 2005 and 2017 turned out to be 949 units, 76.4 percent more than the figure for the 1972-2004 period.

In Seoul, until the late 1990s, planning regulations on building density control were relaxed several times to allow for high-density development (Lee and Bae, 1998: 268). Between 1983 and 1990, the maximum FAR in general residential areas was 250 percent for north Seoul and 300 percent for south Seoul (Seoul Building Ordinance No. 1766, issued May 4, 1983). From November 1990, it was increased to 400 percent (Seoul Building Ordinance No. 2660, issued November 9, 1990) before decreasing to 300 percent in 1998 (Seoul Building Ordinance No. 3499, issued April 30, 1998). This high-density development enabled vertical accumulation (Shin, 2011), leading to a significant increase in the number of both dwellings and residents in, for example, redeveloped neighborhoods. According to the Housing Redevelopment Bureau 
of the Seoul Municipal Government, 65 redevelopment districts, which were completed between 1990 and 1996, experienced a 32 percent average increase in households and a 303 percent increase in the number of dwellings (Seoul Municipal Government, 1998: 32). The data from the Housing Division of the Seoul Municipal Government also shows that, by the end of 2010, the total number of new dwellings constructed in 211 redevelopment project sites reached 206,145 , replacing 79,935 units that became subject to demolition. As the size of the redeveloped flats was much larger than the dwellings they replaced, the overall increase in building volume would have been much larger than the increase in the number of dwellings.

A major outcome of such densification has been the rise of condominiums or apartments as a popular form of residence, transforming Korea into "the republic of apartment" (Gelézeau, 2007). ${ }^{7}$ By 2005, the majority (52.7 percent) of dwellings in Korea turned out to be apartments, and the latest 2018 Census results (Statistics Korea, 2019) reveal that apartments accounted for 61.4 percent of all dwellings. In Seoul, 58 percent of all dwellings were apartments, slightly lower than the national average, largely due to the presence of multi-household units. In Korea as a whole, of all the construction permits received from the central government between 1977 and 1981, apartments constituted 36.3 percent (Korea Land and Housing Corporation, 2016: 236237); between 1982 and 1986, this rate increased to 51.9 percent. From 1992 to $1996,99.1$ percent of all housing construction permits from the central government were apartments (ibid.).

\section{Displacement and dispossession}

One of the problems of property-based urban development in Korea is the proliferation of large-scale displacement of original land users by incoming new users who are financially more affluent. When the Seoul Municipal Government turned its inner-city districts into a new central business district, it cleared the site of poor urban dwellers living in shanty units, driving them away to urban peripheries (Kim, 2010). It is suggested that, during the 14 years between 1958 and 1972, the Seoul Municipal Government displaced to urban peripheries about 300,000 residents (about 17 percent of the municipal population in 1958) housed in 48,718 substandard dwellings (Jeong, 1984, cited in Jang, 1998: 27).

When the commercial redevelopment of substandard neighborhoods began in the early 1980s, the process also entailed the displacement of poor owneroccupiers and most tenants. A field report from the Asian Coalition for Housing Rights suggested that, during the six years of implementing redevelopment projects in Seoul between 1983 and 1988, about 720,000 people were subject to eviction (Asian Coalition for Housing Rights, 1989a, 1989b). A report from a municipal think tank (Kim et al., 1996) examined urban redevelopment projects of the mid-1990s (1993-1996) and estimated that more than four-fifths of tenants were displaced. In the case of housing sites developed by the Korea Land Corporation and based on the Housing Site Development Promotion Act, land 
users other than landlords were largely driven away from what was constructed at the end of each project. This was because landlords were considered the only legitimate stakeholders under the governing law, thereby allowing them to avoid physical displacement.

While poor tenants and owner-occupiers were subject to direct physical displacement from their homes and neighborhoods, another major problem was the loss of affordable dwellings or what Peter Marcuse (1985) referred to as "exclusionary displacement". By the end of 2010, as noted above, urban redevelopment projects led to the demolition of 79,935 units—or 8.3 percent of total available housing stocks in 1980, when property-based urban redevelopment was being conceptualized to eradicate substandard neighborhoods. ${ }^{8}$ This represented a significant loss of affordable housing for low-income populations in Seoul in general-that is, their "exclusionary displacement".

To the extent that gentrification can be understood as a class remaking of urban space at the expense of the original land users' right to stay put (Lees, Shin and López-Morales, 2016), urban development in Korea can be seen as the burgeoning of new-build gentrification, which is deeply embedded in the political economy of Korea's speculative urbanization (Shin and Kim, 2016). The continuous efforts by the Korean developmental state, in alliance with developers, builders and aspirational middle-class investors, to transform the urban-scape of Seoul to become more global and presentable to the world drove the urban poor away from the city center to the urban peripheries, rendering them less visible and dispossessing them of the right to stay put and sustain their livelihoods (Kim, 2010). Even though the role of property owners was pivotal in Korea's housing site development and urban redevelopment, poor property owners were constantly subject to cooptation as well as replacement by affluent investors in urban redevelopment projects (Ha, 2001; Shin and Kim, 2016). Tenants in particular were subject to much harsher treatment, having no right to stay put nor to demand compensation throughout the 1980s. Although they were entitled to relocate to public rental housing from the 1990s, tenants did not have a say in any kind of consultation or planning process. In other words, their rights were dispossessed.

\section{The role of the developmental state and the construction of property hegemony}

As noted previously, land and housing development in Korea until the late 1970s involved a private sector that was too weak to pursue large-scale market-led housing construction, although some builders experimented with the provision of condominium units as new commodities for the emergent middle classes (Sonn and Shin, 2020). Real estate investment received less emphasis in comparison with other investments in production facilities and non-residential construction in times of rapid economic development and condensed urbanization. Only from the mid-1980s did the real estate sector experience a substantial increase in investment when the central government announced an ambitious scheme in 
1980 to supply 5 million dwellings. Another push from the state came in 1988 when the central government publicized its plan to construct 2 million housing units, which was part of the state's effort to restore its legitimacy after having been challenged by the explosive democratization and labor movements (Lee, 2007). The construction of new towns, extensive housing site development, use of state agencies (e.g., the Korea Land Corporation for land development and the $\mathrm{KNHC}$ for social housing construction) and the growth of private builders were all part of this big push to scale-up housing construction.

Rather than the direct provision of housing for the social reproduction of labor, the Korean developmental state was supporting property owners to take the lead in the process of urban development so that the state could continue to earmark available financial resources to support industrial production (Holliday, 2000). Such approaches were consistent with the developmental state's focus on subsidizing the growing conglomerates (chaebols) as capitalists, which were nurtured by the state throughout the 1960s and 1970s to expand industrial production capacity (Park, 1998). Urban poor tenants were largely absent in the state's considerations, while emergent middle-class families utilized their growing purchasing power to tap into the new markets in high-rise condominiums, often with speculative intent, a behavior which began to spring up across Seoul and eventually in other major cities (Shin and Kim, 2016; Yang, 2018).

The involvement of the subsidiaries of large conglomerates (chaebols) as financiers and builders in urban development has been particularly importantindeed, indispensable - to the success of land and housing development in Korea (La Grange and Jung, 2004). Large-scale land development and housing redevelopment projects required long-term commitment resulting from the frequent prolonging of land assembly and disputes between developers and property owners, while heavy upfront costs were to be spent on site preparation, compensation and actual construction ( $\mathrm{Ha}, 2001)$. As a result, top-ranking private builders, which were subsidiaries of chaebols, were involved and became increasingly influential in urban (re)development projects, gaining a kind of brand name (e.g., apartment complexes named after conglomerates, such as Hyundai Apartments or Samsung Apartments). To support private builders and house buyers, the Korean developmental state also established the National Housing Fund (NHF) in July 1981, which provided financial support for homebuyers and builders in the public and private sectors (Ha, 1987: 107-109). Its main sources included the central government budgetary contribution and the National Housing Bonds (Ministry of Construction and Transportation of Korea, 2002: 232). Below-market rate interest loans from the NHF were provided to builders when constructing flats with a floor space of less than 85 square meters (ibid.: 272). The NHF was also the major source for supplementing funding shortages when the redevelopment project funds and land sale revenues were insufficient to finance the purchase of public rental flats in redevelopment projects (Kim et al., 1995; Ministry of Construction and Transportation of Korea, 2002: 227).

To further help builders and property owners financially, off-plan purchasing was widely practiced. This system was first introduced by the Ordinance on 
Housing Supply in 1977 in order to encourage housing construction in general; it also became a powerful tool for urban redevelopment and the mass construction of housing. Under this system, builders were permitted to sell their flats at an early stage of a project, usually when a project reached 10 or 20 percent of the project schedule. The down payment and period instalment from homebuyers assisted builders with the remaining work. The final instalment was made upon the homebuyers moving in (Yoon, 1994: 70-72). For a redevelopment project, it was found that about one-third of the total project costs were spent by builders before they began to receive down payments through the off-plan purchase system (Korea Housing Institute, 2001: 56-57; Lee and Bae, 1998: 277-279).

While the Korean developmental state is conventionally characterized by its bureaucratic efficiency and the dedication of its civil servants to the developmental ethos (Woo-Cumings, 1999), it is important to note that the Korean developmental state has promoted the hegemonic ideology of modernism and nation-building vis-à-vis the real and constructed threat from North Korea, which was mobilized as a means to produce nationwide consensus for the domination of political and economic elites. At the same time, the state resorted to the use of violent and brutal oppression of any resistance that challenged its legitimacy: Notable examples include the so-called Yushin Reform and a series of presidential decrees known as Emergency Measures (Shin, 2018). Such brutal oppression underlay Korea's property-based urban development (Korea Center for City and Environment Research, 1998).

With the rise of the commercial redevelopment of substandard settlements, many low-income tenants staged protests against redevelopment that provided them with no compensation upon displacement (ibid.). In the end, the Korean developmental state introduced concessions to eligible tenants in the form of public rental units for their re-housing ( $\mathrm{Ha}, 2001$; Kim, 2010). Various financial and administrative measures were put in place to both placate the dissenting tenants and ease the pressure on the growth coalition (inclusive of property owners, builders, and the municipal government) that often faced delayed schedules and increased costs. ${ }^{?}$

Throughout the history of urban (social) movements centered on housing justice (ibid.), the focus has largely been on improving the redistributive mechanism in order for a larger share of the appropriated rents, in the form of increased compensation, to be given to the urban poor who faced displacement and increased costs of living in the form of "forced consumption" (Shin, 2008). While such an approach of redistributive justice may have an advantage in ameliorating the hardships that displaced poor people have to endure, it does not change the unjust system itself (see Harvey, 2008; Marcuse, 2009). The introduction of redevelopment compensation, for instance, justified the persistence of property-based urban redevelopment that continued to produce exclusionary displacement for the urban poor who were squeezed into fewer affordable housing stocks, often ending up paying higher rents. The growth of public rental housing stocks from the early 1990s was helpful but inadequate: By 2015, the public rental housing sector constituted 11.8 percent of national housing stocks (or 
15.6 percent of all housing stocks in Seoul), but the share of public housing units with guaranteed rental periods of 20 years or more turned out to be only 5.4 percent over the entire country and 7.0 percent in Seoul (Korea Land and Housing Corporation, 2016).

The hegemonic position of real estate property was strengthened throughout the 1980s and especially during the 2000s, when real estate prices underwent a rapid increase, negatively affecting not only middle-class families but also the working poor who aspired to the accumulation of property assets (Park and Jang, 2016). The fact that Korean households generally depended heavily on real estate properties for household finance highlights the importance of property in the everyday life of Korean people of all generations. According to the results of the household finance survey conducted by Statistics Korea in 2016, property assets account for 69.2 percent of household assets (see Jin and Kim, 2017: 403). Rapid increases in housing prices further helped consolidate this property hegemony: As demonstrated in Figure 4.1, based on the purchase price composite index between 1999 and 2019, housing in Seoul has experienced a 164.6 percent increase on average, which is much higher than the national average of 110.1 percent. Within Seoul, the rate of increase was steeper in southern Seoul (215.5 percent), where luxury condominium units were more concentrated. The

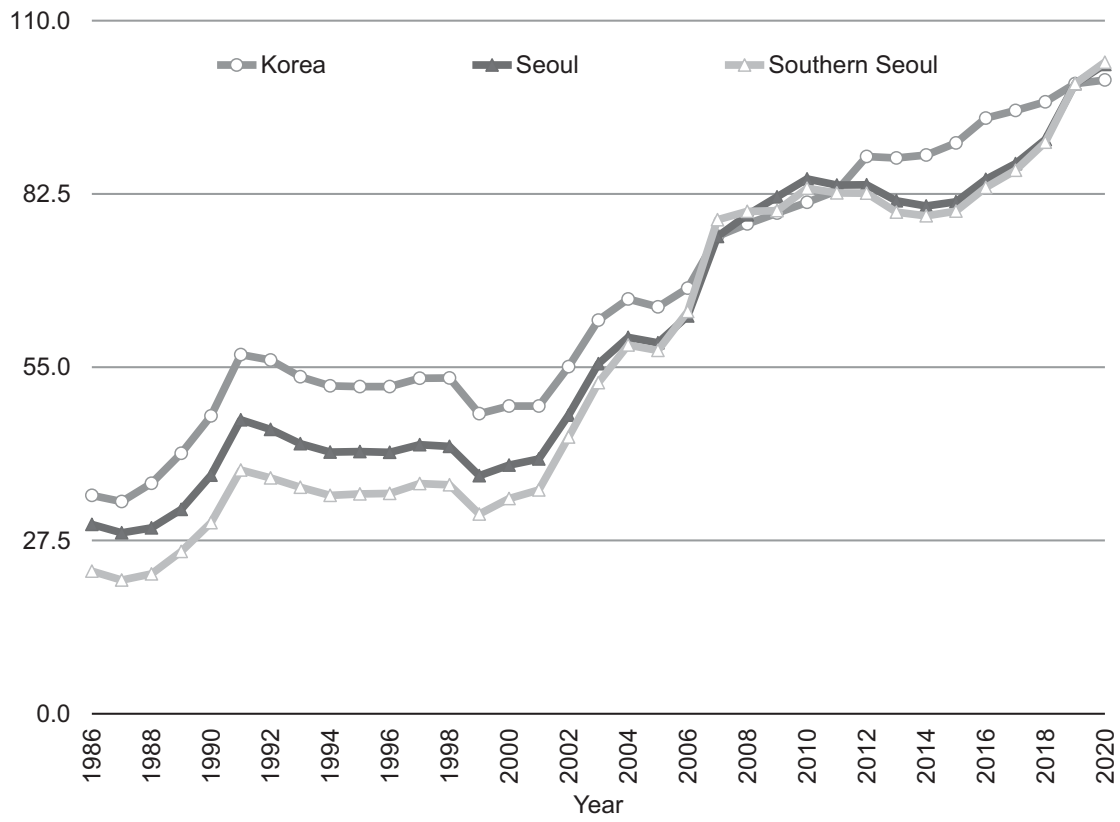

Figure 4.1 Housing Purchase Price Composite Indices (each year index is based on January $2019=100.0)$.

Source: Kookmin Bank web site. URL: https://onland.kbstar.com 


\section{Hyun Bang Shin}

overall trend of long-term increase in housing prices during the past decades is evident, suggesting that investors in housing would be unlikely to lose their money on a long-term basis. This guarantee of returns on real estate investment sustains property hegemony in Korea and conditions its contemporary urban politics (Shin, 2018).

\section{Conclusion}

The urban transformation in Korea during the economic take-off under the Korean developmental state benefited from the proliferation of the propertybased urban development model, which was deeply embedded in the specific spatiotemporal contexts that accompanied particular sets of state-society and statecapital relations. In essence, property-based urban development, characterized by its speculative nature and verticality, is effectively a rent gap-based revenuesharing model. Unfortunately, the lessons from Korea entailed adverse impacts on extant land users (especially poor owner-occupiers and tenants), who incurred direct physical displacement because they were not part of the policy design and could hardly make financial contributions. Exclusionary displacement through the loss of affordable housing stocks was another detrimental consequence for the urban poor. The Korean urban development experience could therefore be equated with exacerbated social injustice as the developmental gains were disproportionately redistributed in favor of more affluent house buyers and builders. Land-based revenues through rent gap closure and any profits resulting from commercial development of land and housing largely went into the pockets of developers and homebuyers, including speculative investors, while the improved public facilities provided in redevelopment neighborhoods and new towns were consumed by the new users rather than previous users. In other words, urbanization through gentrification has become a de facto state project in Korea (Shin and Kim, 2016; Lees, Shin and López-Morales, 2016).

The role of the developmental state has been influential. In addition to nurturing the growth of industrial capital, it has used its planning power-such as land expropriation-to develop land in a speedy way; moreover, densification through granting a high FAR has created opportunities for the state to attract private builders and prospective real estate buyers, which has helped sustain property-based urban development projects. In the case of projects governed by the Housing Site Development Promotion Act, the involvement of a state agency, the Korea Land Corporation, was key to fast-tracking planning processes for land assembly as well as clearing barriers to private builders by taking care of possible disputes with landlords in the process of land expropriation, which was presented as development for public purpose under the law despite its unequal nature in practice. The authoritarian developmental state initially resorted to the use of state power and oppression to realize the urban development that accompanied widespread displacement and dispossession of extant land users. Eventually, however, the state resorted to the emerging hegemony of property to sustain property-based urban development. 
What can be learned from urban transformation "Korean style" for cities in the Global South? First, from the public finance perspective, the use of landbased revenues through rent gap closure can be a remedy for financially weak governments in the Global South-although appropriate measures are needed for the prevention of displacement of people and the dispossession of the rights of the property-less. Institutional infrastructure, such as the National Housing Fund, can be helpful in enabling the pooling of resources, thereby easing the fiscal burden on the national state and local states. The use of state corporations, such as the Korea Land Corporation, can also be effective. However, whether or not such utilization of institutional infrastructure serves the purpose of constructing "the just city" (cf. Fainstein, 2011) would depend on how much progressive movements exert pressure on the state and capital (Harvey, 2008; Marcuse, 2009).

Second, the expanding private sector throughout the 1970s and 1980s helped the consolidation of the property-based urban development model by participating in speculative real estate markets as builders and financiers, embodying the property hegemonic ideology. Such private sector players included the subsidiaries of large conglomerates that had been nurtured by the Korean developmental state; it also included middle-class families, whose increasing affluence helped finance the growth of the real estate market by consuming housing units en masse. The involvement of private builders as de facto developers in redevelopment projects was, to some extent, beneficial for the completion of projects by utilizing their expertise on project management and construction; however, it also raises questions about the equitable outcome of such development due to its profit-oriented nature. Capping the maximum share of profits to be enjoyed by private builders may be necessary in order for development gains to be retained for public use (Helbrecht and Weber-Newth, 2018).

Third, urban development "Korean style" has been possible under spatially and temporally bound conditions of social and economic development, which are situated in "distinctive historical conjunctures" (Roy, 2016: 317). These conditions are hard to replicate elsewhere, including the Global South, rendering the success of transferring a development model questionable. This is a sentiment shared by Beng Huat Chua (2011) in his discussion of the worlding of the Singapore model. While the role of the Korean developmental state has been influential, there is a need to understand the state from a relational perspective, acknowledging the growth coalition between the state and large conglomerates (Park, 1998) and between the state and the emergent middle class. It was not the autonomous and efficient state that made urban transformation possible; rather, it was the state working through relational politics as it aimed at sustaining its power in the face of challenges from the democratization movement and labor movements. The state also worked with industrial capital during the Cold War era to benefit from geopolitical tensions: One recent finding has been the ways in which the Vietnam War provided opportunities for conglomerates to expand (see Glassman and Choi, 2014). Without these national and geopolitical conditions, the state would not have been able to pursue the development of new housing markets through mass housing construction that depended heavily on inputs 


\section{Hyun Bang Shin}

from conglomerates and middle-class buyers. The rise of property hegemony also lured the working class and the poor with aspirations to join the so-called "propertied class" (Son, 2008), thereby endorsing the urban policies of the developmental state, which were unjust and unequal, even though absolute housing poverty itself had eased.

Fourth, property-based urban development in Korea has resulted in, and benefited from, uneven development that intensified regional disparity and socioeconomic inequality. Unequal distributions of property wealth have been a major problem marring the flourishing of society. They have been a constant source of dispute, despair, and frustration among families, especially those on the lower end of the income distribution. In this way, they also constitute a political agenda. Geographically, major metropolitan areas saw a concentration of investment in real estate, while small cities and counties saw weak demand for such investment. The experience of speculative urbanization that was manifested in Seoul has spread to other regional cities, replicating vertical accumulation even in more rural areas that would not usually expect a high demand for housing.

Therefore, a final lesson from Korean urban development is that, while acknowledging the need to strengthen public sector finance and to make use of land as an asset to finance urbanization, it is also necessary to ensure that appropriated rents are used for investment in "social infrastructure" to build an inclusive society and reduce inequality. Here, social infrastructure may refer to the provision of social facilities and communal spaces, such as health and educational facilities (e.g., medical centers, libraries), cultural amenities, social housing, green spaces, community facilities and networks, and so on, which would help the social reproduction of labor and family life. For Latham and Layton (2019: 9), social infrastructure enables people to "socialise and connect with others", promoting "shared use and collective experience". ${ }^{10}$ In Korea, it was the Asian financial crisis of the late 1990s that drove the Korean developmental state to pay more attention to the provision of a social safety net so that there is a minimum provision of social infrastructure to sustain livelihoods. Nevertheless, there is still a preponderance of speculative fervor and the widening asset inequality that undermines the construction of an inclusive and just society. Therefore, more attention ought to be paid to the accumulation of social infrastructure as well as ensuring that the market is regulated to prevent the negative consequences of property-based urban development and its propensity to speculation through exploitation of the "property-less". In the long term, there has been a call to acknowledge the city as an "urban commonwealth" (Kohn, 2016), where the wealth created in the course of development is controlled by the public as a collective asset to be spent according to need rather than for the sake of accumulation.

\section{Acknowledgments}

The writing of this chapter has been partly supported by the National Research Foundation of Korea Grant funded by the Korean Government [NRF-2017S1A3A2066514]. 


\section{Notes}

1 Methodological nationalism treats the scale of the nation-state as the exclusive unit of analysis for explaining social phenomena, thereby neglecting the importance of multiscalar politics that are inclusive of local scales as well as transnational scales. Daniel Chernilo (2006: 129) further states that "[m]ethological nationalism presupposes that the nation-state is the natural and necessary form of society in modernity and that the nation-state becomes the organising principle around which the whole project of modernity cohered".

2 The "clearance and redevelopment" scheme under the 1973 Temporary Act consisted of two different approaches. The first approach was often referred to as "self-help clearance and redevelopment" and was applied between 1973 and 1975 (Kim et al. 1996: 87). Land was to be redefined into larger housing lots (usually at least 165 square meters) so that shared ownership among several households would make it easier to build "corporative housing" of higher density. The dwelling owners were required to finance all the costs incurred for the purchase of public lands they illegally occupied, for temporary accommodation until re-housing, and for the reconstruction of houses after clearance. The second approach that presented important implications for practices in the 1980s was known as "consigned redevelopment". Owner-occupiers were to establish a steering committee and bring in a private builder in charge of removing dwellings and producing new apartment flats or multi-household units. The municipal government was to supervise the process as well as nominate builders of good reputation. Twenty to 30 households were to come together so as to define approximately 1,000 square meters of housing lot, thereby constructing dwellings with higher density (Kim et al. 1996: 96).

3 According to the Master Plan for Housing Redevelopment in Seoul, finalized in 1998, the examination of more than 100 redevelopment project sites showed that about twofifths of land turned out to be in public ownership and that the majority of houses in redevelopment sites were, in fact, illegal (Seoul Municipal Government 1998: 20-21).

4 The Urban Planning Act has been absorbed into the Act on Planning and Use of National Territory since January 1, 2003.

5 Redevelopment projects are led by redevelopment associations made up of property owners as members. New flats produced as part of redevelopment consist of (a) flats allocated to members of the redevelopment association, who purchase these flats at construction cost; (b) flats for sale in the new housing market for profits; and (c) public housing units as required by local governments.

6 Urban Redevelopment Project statistics are available at http://stat.molit.go.kr/ (last accessed April 30, 2020).

7 Apartments were perceived as a symbol of the modern lifestyle and received the attention of the state from the 1960s (see Sonn and Shin 2020: 872-873).

8 For the historic data on housing stocks, see the Seoul Research Data Service website on housing. Available at: http://data.si.re.kr/node/343 (last accessed April 30, 2020).

9 In Seoul, in accordance with the Urban Redevelopment Act and the Municipal Ordinance on Urban Redevelopment, a certain proportion of urban planning tax income ( 5 percent until 1982 and 10 percent thereafter) was earmarked for a special municipal account for urban redevelopment. The fund accumulated in this way was called the "redevelopment project fund", which was used by the government to purchase public rental units provided in the redevelopment neighborhoods (Kim et al. 1995). The sales revenue of public land in redevelopment districts was also earmarked for the purchase of these rental units. 


\section{Hyun Bang Shin}

10 One of the policy examples is the latest London Plan in the UK, which has a dedicated chapter on social infrastructure. Here, social infrastructure is understood as covering "a range of services and facilities that meet local and strategic needs and contribute towards a good quality of life. It includes health provision, education, community, play, youth, early years, recreation, sports, faith, criminal justice and emergency facilities", and plays "an important role in developing strong and inclusive communities" (Mayor of London, 2019: 240).

\section{References}

Asian Coalition for Housing Rights (1989a). Battle for Housing Rights in Korea: Report of the South Korea Project of the Asian Coalition for Housing Rights. Bangkok: Asia Coalition for Housing Rights [and] Third World Network.

Asian Coalition for Housing Rights (1989b). Evictions in Seoul, South Korea. Environment and Urbanization 1(1), pp. 89-94.

The Bank of Korea (2004). National Accounts 2004. Seoul: The Bank of Korea.

Castells, M. (1992). "Four Asian Tigers with a Dragon Head: A Comparative Analysis of the State, Economy and Society in the Asian Pacific Rim," in R. P. Appelbaum and J. W. Henderson (eds.), States and Development in the Asian Pacific Rim. Newbury Park, CA: Sage, pp. 33-70.

Castells, M., Goh, L. and R. Y.-W. Kwok, (1990). The Shek Kip Mei Syndrome: Economic Development and Public Housing in Hong Kong and Singapore. London: Pion.

Chernilo, D. (2006). "Methodological Nationalism and its Critique," in G. Delanty, and K. Kumar (eds.), The SAGE Handbook of Nations and Nationalism. London: Sage Publications, pp. 129-140.

Choi, B.-D. (2010). "Gyeongbu Highway: Political Economic Geography of Mobility and Demarcation," Journal of the Economic Geographical Society of Korea 13(3), pp. 312-334.

Choi, Y.-J. (2014). "The Historical Background of the Development of Changwon Industrial Complex: A Geopolitical Economy Approach," Journal of the Korean Geographical Society 49(2), pp. 178-199.

Chua, B. H. (2011). "Singapore as Model: Planning Innovations, Knowledge Experts," in A. Roy and A. Ong (eds.), Worlding Cities: Asian Experiments and the Art of Being Global. Chichester: Wiley-Blackwell, pp. 29-54

Clark, E. (1988). "The Rent Gap and Transformation of the Built Environment: Case Studies in Malmö 1860-1985," Geografiska Annaler 70B (2), pp. 241-254.

Dong'a Ilbo (1980). Plan for the Construction of 5 Million Dwellings. October 3.

Doucette, J. and B-G. Park, eds (2019). Developmental Cities? Interrogating Urban Developmentalism in East Asia. Leiden, The Netherlands: Brill.

Economic Planning Board of Korea (1982). 1980 Population and Housing Census Report: Vol. I: Complete Enumeration, 12-1: Whole Country. Seoul: National Bureau of Statistics, Economics Planning Board of Korea.

Fainstein, S. S. (2011). The Just City. New York: Cornell University Press

Gelézeau, V. (2007). The Republic of Apartments: Views of a French Geographer on South Korean Apartment Complexes. Seoul: Humanitas (In Korean).

Glassman, J. and Y-J. Choi (2014). "The Chaebol and the U.S. Military-Industrial Complex: Cold War Geopolitical Economy and South Korean Industrialization," Environment and Planning A: Economy and Space 46(5), pp. 1160-1180. 
Ha, S.-K. (2001). "Substandard Settlements and Joint Redevelopment Projects in Seoul," Habitat International 25, pp. 385-397.

Ha, S.-K. (1987). "Korea," in S.-K. Ha (ed.), Housing Policy and Practice in Asia. London: Croom Helm, pp. 80-116.

Harvey, D. (1978). "The Urban Process Under Capitalism: A Framework for Analysis," International Journal of Urban and Regional Research 2(1-4), pp. 101-131.

Harvey, D. (2012). Rebel Cities: From the Right to the City to the Urban Revolution. London: Verso.

Helbrecht, I. and F. Weber-Newth (2018). "Recovering the Politics of Planning: Developer Contributions and the Contemporary Housing Question," CITY22(1), pp. 116-129.

Holliday, I. (2000). "Productivist Welfare Capitalism: Social Policy in East Asia," Political Studies 48(4), pp. 706-723.

Jang, S -H. (1998). "Development of Slum Clearance Policies in Seoul," in S.-H. Kim, H.-G. Jeon, J.-H. Jang, S.-K. Ha and S.-H. Jang (eds.), Eviction from the Perspective of Evictees: The History of Evictees' Movement in Seoul (In Korean: Cheolgeomin yi bon cheolgo). Seoul: Korea Centre for City and Environment Research, pp. 21-83.

Jeong, J.-H. (1984). "The Possibility of Taking A Third World Perspective for Research on Korean Society" (in Korean: Hangug Sahoe Yeongu-e iss-eo-seo Je 3 segyejeog Jeobgeun-ui Ganeungseong), Sungshim Yeodae Nonmunjib 16, pp. 126-132.

Jin, M.-Y. and S.-H. Kim (2017). Searching for the Desirable Housing Policy: The Trend of Global Housing Markets and the Future of Korea (in Korean: Ggum'eui Jutaeg Jeongchaeg'eul Chajaseo). Seoul: O’Woleui Bom.

Jung, S.-y. (2019). "LH Corp. Exports Smart City Technology to Middle East," Business Korea, January 28. Available at: www.businesskorea.co.kr/news/articleView. html?idxno=28699. [Accessed May 4, 2020].

Kim, H.-C., H. C. Kim, S. J. Jeon, J. G. Seon (1995). A Study on the Development and Management of Financial Resources for Urban Renewal Projects. Seoul: Housing Research Institute, Korea National Housing Corporation.

Kim, K. J., K.-J. Kim, I.-J. Lee and S.-H. Jeong (1996). Substandard Housing Redevelopment in Seoul: 1973-1996 (in Korean: Seoul-si Jutaeg Gaelyang Jegaebal Yeonhyeog Yeongu). SDI Research Series Completion Report 96-R-08. Seoul, Seoul Development Institute.

Kim S.-H. (2010). "Issues of Squatters and Eviction in Seoul," City, Culture and Society 1(3), pp. 135-143.

Kim, W.-J. (1996). Economic Growth, Low Income and Housing in South Korea. Basingstoke: Macmillan.

Kim, Y.-S. (2018). "Korean-style Apartment Complexes Go Global," The Korea Herald, December 27. Available at: www.koreaherald.com/view.php? ud=20181227000537. [Accessed May 3, 2020].

Kohn, M. (2016). The Death and Life of the Urban Commonwealth. New York: Oxford University Press.

Korea Center for City and Environment Research (eds.) (1998) Eviction in the Eyes of Evictees: The History of Evictees' Movement in Seoul. Seoul: Korea Center for City and Environment Research.

Korea Housing Institute (2001). Improvement of Housing Policy and Industry of 2000s: Reconstruction and Redevelopment (in Korean: 2000 Nyeondae Jutaeg Saneop mit Jeongchaeg Banghyang: Jaegeonchug Jaegabal-eul Jungsim-euilo). Seoul: Korea Housing Institute.

Korea Land and Housing Corporation (2016). 2016 Yearbook of Land and Housing Statistics. Jinju: Korea Land and Housing Corporation. 


\section{Hyun Bang Shin}

Korea National Housing Corporation (2001). Housing Statistical Yearbook. Sungnam: Housing and Urban Research Institute, Korea National Housing Corporation.

Korea National Housing Corporation (2004). Housing Statistical Yearbook. Sungnam: Housing \& Urban Research Institute, Korea National Housing Corporation.

Korea Research Institute for Human Settlements (1981). Housing Handbook. Seoul: Korea Research Institute for Human Settlements.

La Grange, A. and H. N. Jung (2004). "The Commodification of Land and Housing: The Case of South Korea," Housing Studies 19(4), pp. 557-580.

Latham, A. and J. Layton (2019). "Social Infrastructure and the Public Life of Cities: Studying Urban Sociality and Public Spaces," Geography Compass . doi: 10.1111/ gec3.12444

Lee, J.-Y. (2000). "The Practice of Urban Renewal in Seoul, Korea: Mode, Governance, and Sustainability," Presented at the 2nd International Critical Geography Conference, August 9-13, Taegu, Korea.

Lee, M. H. (2015). "LH to Export Location Knowhow for New City Development to Africa," Korea Bizwire, February 24. Available at: http://koreabizwire.com/lh-toexport-location-knowhow-for-new-city-development-to-africa/30687. [Accessed May 3, 2020].

Lee, N. (2007) The Making of Minjung: Democracy and the Politics of Representation in South Korea. Ithaca, NY: Cornell University Press.

Lee, Y.-O. and K.-D. Bae (1998). "A Study of Housing Renewal Problems, Measures and New Directions" (in Korean: Seoul-si eui Jegaebal Munje wa Haebeob Gochal), The Journal of Urban Sciences. The University of Seoul Dosi Gwahag Nonchong 24, pp. 263-87.

Lees, L., H. B. Shin and E. López-Morales(2016). Planetary Gentrification. Cambridge: Polity Press.

Lett, D. P. (1998). In Pursuit of Status: The Making of South Korea's New Urban Middle Class. Cambridge: Harvard University Press.

Marcuse, P. (2009). "From Critical Urban Theory to the Right to the City," City 13, pp. 185-197.

Marcuse, P. (1985). "Gentrification, Abandonment and Displacement: Connections, Causes and Policy Responses in New York City," Journal of Urban and Contemporary Law 28, pp. 195-240.

Mayor of London (2019). The London Plan: Intend to Publish (clean version). London: Greater London Authority. Available at: www.london.gov.uk/sites/default/ files/intend_to_publish_-_clean.pdf. [Accessed May 11, 2020].

Ministry of Commerce, Industry and Energy of Korea (2001). Trends in Foreign Direct Investment (in Korean: Oe-gug-in Tuja Donghyang). Gwacheon: Ministry of Commerce, Industry and Energy of Korea.

Ministry of Construction and Transportation of Korea (2002). Housing White Paper (in Korean: Jutaeg Baegseo). Gwachon: Ministry of Construction and Transportation of Korea.

Ministry of Construction and Transportation of Korea (2000). Operational Manual for Housing Redevelopment (in Korean: Jutaeg Jaegaebal Ubmu Pyeonlam). Gwachon: Ministry of Construction and Transportation of Korea.

Mobrand, E. (2008). "Struggles Over Unlicensed Housing in Seoul, 1960-80," Urban Studies 45(2), pp. 367-389.

National Statistical Office of Korea (2002). Major Statistics of Korean Economy (in Korean: 2002 Sangbangi Hangug Juyo Gyeongje Jipyo). Daejeon: Korea National Statistical Office. 
National Statistical Office of Korea (1994). Major Statistics of Korean Economy (in Korean: Hangug Juyo Gyeongje Jipyo). Daejeon: Korea National Statistical Office.

Park, B.-G. (1998). "Do Tigers Sleep at Night? The State's Role in Housing Policy in South Korea and Singapore," Geography 74(3), pp. 272-288.

Park, B.-G. and J. B. Jang (2016). "Gangnam-ization and Korean Urban Ideology," Journal of the Korean Association of Regional Geographers 22(2), pp. 287-306.

Percival, T. and P. Waley (2012). "Articulating Intra-Asian Urbanism: The Production of Satellite Cities in Phnom Penh," Urban Studies 49(13), pp. 2873-2888.

Planning and Coordination for the Cabinet Office (1972). Administration White Paper (in Korean: Haengjeong Baegseo). Seoul: Government of the Republic of Korea.

Planning and Coordination for the Cabinet Office (1967). Administration White Paper (in Korean: Haengjeong Baegseo). Seoul: Government of the Republic of Korea.

Power, A. (1993). Hovels to Highrise: State Housing in Europe. London, New York: Routledge.

Roy, A. (2016). "When is Asia?” The Professional Geographer 68(2), pp. 313-321.

Roy, A. and A. Ong, eds (2011). Worlding Cities: Asian Experiments and the Art of Being Global. Chichester: Wiley-Blackwell.

Seoul Municipal Government (1998). Master Plan for the Housing Redevelopment in Seoul (in Korean: Seoul Teugbyolsi Jutaeg Jaegaebal Gibon Gyehoeg). Seoul: Seoul Metropolitan Government.

Seoul Municipal Government (1974). Municipal Administrative Outline (in Korean: Sijeong Gaeyo). Seoul: Seoul Metropolitan Government.

Seoul Municipal Government (1973). Municipal Administrative Outline (in Korean: Sijeong Gaeyo). Seoul: Seoul Metropolitan Government.

Seoul Municipal Government (1970). Municipal Administrative Outline (in Korean: Sijeong Gaeyo). Seoul: Seoul Metropolitan Government.

Shin, H. B. (2019). "Asian urbanism," in A. M. Orum (ed.), The Wiley-Blackwell Encyclopedia of Urban and Regional Studies. Hoboken, NJ: Wiley-Blackwell. doi: 10.1002/9781118568446.eurs0010

Shin, H. B. (2018). "Urban Movements and the Genealogy of Urban Rights Discourses: The Case of Urban Protesters Against Redevelopment and Displacement in Seoul, South Korea," Annals of the American Association of Geographers 108(2), pp. 356-369.

Shin, H. B. (2011). "Vertical Accumulation and Accelerated Urbanism: The East Asian Experience," in M. Gandy (ed.), Urban Constellations. Berlin: Jovis, pp. 48-53.

Shin, H. B. (2009). "Property-based Redevelopment and Gentrification: The Case of Seoul, South Korea," Geoforum 40(5), pp. 906-917.

Shin, H. B. (2008). "Living on the Edge: Financing Post-displacement Housing in Urban Redevelopment Projects in Seoul," Environment and Urbanization 20(2), pp. 411-426.

Shin, H. B. and S.-H. Kim (2016). "The Developmental State, Speculative Urbanisation and the Politics of Displacement in Gentrifying Seoul," Urban Studies 53(3), pp. 540-559.

Smith, N. (1996). The New Urban Frontier: Gentrification and the Revanchist City. London: Routledge.

Smith, N. (1979). "Toward a Theory of Gentrification: A Back to the City Movement by Capital Not People," Journal of the American Planning Association 45, pp. 538-548.

Song, J.-S. (2009). South Koreans in the Debt Crisis: The Creation of a Neoliberal Welfare Society. Durham: Duke University Press.

Son, J.-M. (2000). "The Construction of 5 Million Housing Units and the Development of Mokdong New Town," Planning and Policy 230, pp. 106-125. 


\section{Hyun Bang Shin}

Son, N.-G. (2008) The Era of Class Society of Real Estate, Seoul: Humanitas.

Sonn, J. and H. B. Shin (2020). "Contextualizing Accumulation by Dispossession: The State and High-rise Apartment Clusters in Gangnam, Seoul," Annals of the American Association of Geographers 110(3), pp. 864-881.

Statistics Korea (2019). Press Release of 2018 Population and Housing Census: Registered Census Method Results. Available at: http://kostat.go.kr/portal/korea/kor_nw/1/ 1/index.board? bmode $=$ read\&aSeq=377115. [Accessed April 30, 2020].

van Noorloos, F. and M. Leung (2017). "Circulating Asian Urbanisms: An Analysis of Policy and Media," in E. Woertz (ed.), Reconfiguration of the Global South: Africa, Latin America and the "Asian Century." New York: Routledge, pp. 125-142.

Watson, V. (2014). "African Urban Fantasies: Dreams or Nightmares?" Environment and Urbanization 26(1), pp. 215-231.

Woo-Cumings, M., ed. (1999). The Developmental State. Ithaca, NY: Cornell University Press.

Yang, M. (2018). From Miracle to Mirage: The Making and Unmaking of the Korean Middle Class, 1960-2015. New York: Cornell University Press.

Yoon, I.-S. (1994). Housing in a Newly Industrialised Economy: The Case of South Korea. Aldershot: Avebury, p. 1717. 


\title{
5 From commodities to community engagement
}

\author{
Localities and urban development in \\ Seoul, Korea
}

\author{
Blaž Križnik and Su Kim
}

\section{Introduction}

The locality is a particular place-based form of social and economic organization. In this chapter, we will focus on deprived residential areas in cities, although locality can refer to very different places. Massey (1994: 121) emphasizes that localities are "not so much bounded areas as open and porous networks of social relations". Localities as social relationship networks are constructed and maintained through an ongoing interaction between individuals in a situation of spatial proximity. On the one hand, localities and their meanings are open to different and contested interpretations, which individuals and social groups attach to a particular place (Cohen, 1985; Lash, 1994). On the other hand, spatial proximity can strengthen social interaction and contribute to the formation of solidarity and shared meanings among the individuals. As a result, localities, as shared communal spaces, not only sustain existing but can also build alternative social relations, practices and meanings to those that dominate the capitalist city (Castells, 1983; Harvey, 2012).

In the capitalist city, property markets directly affect localities. Lefebvre (2003: 35) pointed out that urban space "is better suited than it has ever been for the accumulation of capital". In advanced capitalism, localities have an important role not only as sites of production, consumption and social reproduction, but also for absorbing surplus capital through urban development and property markets (Harvey, 2001). The commodification of localities, resulting from their role in the accumulation of capital, extends beyond speculative investments in the built environment towards commodification of their histories, shared meanings and cultures (Short and Kim, 1998; Križnik, 2009). These de-urbanizing tendencies increase social segregation and spatial fragmentation in cities, turning them into archipelagos of over-controlled, disconnected and privatized urban enclosures (Hodkinson, 2012; Sassen, 2017).

The state often plays an important role in facilitating the accumulation of capital through the commodification of localities (Harvey, 2001; Smith, 2002). Moreover, the state considers localities to be important for the delivery of public 
services and for strengthening state legitimacy. Community engagement, in particular, is expected to improve social relationship networks in localities, empower communities to manage their living environment and expand local autonomy (Day, 2006). Engaging communities in decision-making is, therefore, an integral part of the localized sustainability agenda in cities (Manzi et al., 2010). Community engagement, however, does not always lead to community empowerment. As an instrument of neoliberal governmentality, community engagement can constitute communities as collectively governable subjects, which in practice confines their local autonomy (Robson, 2000; Ledwith, 2011; Somerville, 2016). In response, the grassroots not only struggle against the commodification of localities but also contest state involvement with an aim to recover communal life in the localities (Massey, 1994; Ledwith, 2011; Harvey, 2012). This makes localities the key sites of grassroots struggles over the "historical meaning of urban" (Castells, 1983: 71).

In South Korea (hereafter Korea), property markets were highly instrumental for the industrialization and urbanization of the country (Joo, 2019). This has been particularly evident in Seoul. Over the past six decades, the city experienced a rapid urban development, which substantially contributed to the economic growth of the once impoverished country. In this context, improvement of deprived residential areas had an important role in addressing the housing shortages in the city, as well as for absorbing surplus capital through the expansion of property markets (Park, 1998; Douglass, Ard-Am and Kim, 2001). This led to a massive property-led urban redevelopment and resulted in the large-scale commodification of localities, which was facilitated by a strong developmental state (Shin and Kim, 2016; Cho and Križnik, 2017).

Recently, the Seoul Metropolitan Government (SMG) recognized the negative consequences of property markets on localities. For the former Seoul Mayor Park Won-soon (2014: 443), restoring communal life in localities became an integral part of his political agenda, acknowledging that "a sense of community is essential in creating a more humane society". The changing state-community relationship led to the expansion and institutionalization of community engagement and contributed to a major shift in approaching the improvement of deprived residential areas in Seoul (Cho and Križnik, 2017: Kim, 2018b; Wolfram, 2019). At the same time, the shift could be attributed to a strong civil society and a long history of community movements in Seoul (Jeong, 2012; Kim, 2017a, Kim, 2017b; Kim and Križnik, 2018; Shin, 2018).

This chapter examines the changing relation between the state, property markets and community and their role in the transformation of localities and urban development in Seoul. ${ }^{1}$ It is organized into five sections. A brief overview of major approaches, addressing the improvement of deprived residential areas in Seoul, their consequences on localities and community engagement follows the introduction section. Transformation and its consequences on locality, state involvement and state-community relationship and the evolution of community movement in Songhak Maeul and Seowon Maeul are compared in the following two sections. The final section discusses the implications of recognizing localities 
as sites of grassroots struggles and community engagement for urban development and international development cooperation in Korea.

\section{Background: transformation of localities in Seoul}

\section{Improvement of deprived residential areas}

Korea is known as one of the "four Asian Tigers" for its successful social and economic development in the past (Castells, 1992: 32). Seoul played a highly instrumental role in the transformation of the impoverished country (Cho and Križnik, 2017; Joo, 2019). The rapidly industrializing city attracted hundreds of thousands of migrants in a search for jobs and a better life. Its population more than doubled from 2,444,874 in 1960 to 5,536,169 in 1970 and surpassed 10 million by the early 1990s (SMG, 1998, 2018). Population growth resulted in enormous housing demand, which the state alone could not resolve. Many migrants had no choice but to settle in shantytowns of extreme poverty, which in the early 1970s housed about a third of all households in the city (Kim and Yoon, 2003). Most of the shantytowns were eventually demolished with their residents displaced, although the state in some cases tried to improve their living environment by encouraging self-help and by providing basic housing. Lack of public funding, however, made these early attempts to improve deprived residential areas ineffective and had limited success in resolving the housing shortage in the city (Chang, Nam and Lee, 2018). ${ }^{2}$

In the 1970s, the state turned towards the market and aligned with large construction corporations to address housing shortages more effectively (Park 1998). At the same time, the state tried to help the struggling construction sector, expand property markets and facilitate accumulation of the surplus capital (Shin and Kim, 2016; Chang, Nam and Lee, 2018). SMG introduced the Joint Redevelopment Project (Hapdong jaegaebal, JRP) in 1983 to further encourage the transformation of deprived urban areas and improve housing provision in the city. JRP was carried out in a partnership between the landowners' redevelopment associations, which contributed the land, and private construction corporations, which provided funding and expertise for urban redevelopment (Cho, 1998; Kim, 2010). In this way, traditional residential areas were transformed into modern residential complexes. After their completion, the landowners moved in and the remaining housing units were sold on the market with high profits due to the extreme density of such property-led urban redevelopment. Large speculative investments were absorbed through JRP, which over the next decades became the major approach, addressing the improvement of deprived residential areas in Seoul (Kim, 2010; Shin and Kim, 2016; Kim, 2018a).

In 2002, SMG (2010a) introduced New Town Development (New town saeop, NTD) to address regional disparities, resulting from speculative investments on the property markets in the past and to promote balanced urban development of the city (Križnik, 2009; Shin and Kim, 2016). At the same time, NTD aimed to 
attract investments to the shrinking property markets, by expanding the number and size of urban redevelopment areas "to 2.4 times the area redeveloped between 1973 and 2008" (Kim, 2010: 141). These efforts were largely focused on northern Seoul, which was less developed than the wealthy southern part of the city. Fostering balanced urban development and expanding property markets, however, could not be achieved without state involvement. Although NTD was based on a partnership between redevelopment associations and construction corporations, SMG (2010a) planned to oversee their planning and provide social amenities and infrastructure in New Towns. The state also promised to involve the residents in decision-making, which was a rare practice at the time (Križnik, Cho and Kim, 2019).

High hopes of a comprehensive urban redevelopment, better living environment and investment opportunities brought NTD to virtually every district of Seoul by the mid-2000s. As many as 26 localities were eventually designated as New Towns (SMG, 2010a). After 2008, however, NTD came to a sudden halt from the global economic slowdown, declining property markets, as well as heightened social conflicts between stakeholders. Conflicts between landowners and tenants, related to evictions and compensations, were particularly troublesome (Križnik, 2018). For the former Seoul Mayor Park Won-soon (2014: 443), the "New Town Development project was controversial for tearing down old houses and evicting residents from their homes". SMG responded with the New Town Exit Strategy, which led to the cancellation of many NTD projects after 2012 (Chang, Nam and Lee, 2018).

At the same time, SMG shifted its approach, addressing the improvement of deprived residential areas by promoting urban regeneration rather than urban redevelopment. ${ }^{3}$ The Liveable Maeul-making Pilot Project (Salgijoeun maeulmandeulgi sibeomsaeop, LMPP) and Seoul Human Town project were launched in 2008 and 2010 (SMG, 2010b). In 2012, the Residential Environment Management Project (Jugeo hwangyeong gwalli saeop) was introduced to improve infrastructure, provide support for the renovation of individual houses and strengthen social relationship networks in low-rise residential areas (Kim, 2018b). Furthermore, the state introduced the national urban regeneration strategy, which led to the Seoul-type Urban Regeneration Project (Seoulhyeong dosijaesaengsaeop) in 2014 (Yu, 2018). Although these approaches are different in terms of aims and institutional frameworks, they all focus on state-led improvement of deprived urban areas through citizen participation in planning and decision-making (Križnik, Cho and Kim, 2019; Wolfram, 2019).

\section{Commodification of localities}

Property-led urban redevelopment seems to have resolved housing shortages in the city. In the early 1980s, the housing supply rate in Seoul was below 50 percent, while in 2000 it reached 77 percent. Today, the housing supply rate is about 96 percent (Križnik, Cho and Kim, 2019). JRP considerably improved 
housing provision during the 1980s and 1990s, while NTD followed suit in the 2000s. As a result, most of the shantytowns, as well as many traditional residential areas in the city, were demolished and transformed into modern residential complexes (apateudanji), offering a better living environment for the new residents (Kim, 2010; Chang, Nam and Lee, 2018). The extent of this transformation is reflected in a dramatic increase of high-rise apartments, which nowadays dominate the city and accommodate 58 percent of all housing units in Seoul. In 1970, in contrast, high-rise apartments accounted for only 4 percent of all housing units (SMG, 2018). Housing supply improvement, resulting from a massive transformation of localities, suggests that property-led urban redevelopment in Seoul was successful.

New housing, however, was not affordable for everyone. Park (1998: 278) noticed that "public and private sectors have focused on providing forprofit housing, so that housing for the poor, which is unprofitable, has been neglected". In consequence, the lack of affordable housing most negatively affected low-income residents. Although they represent the majority of the population in deprived residential areas, low-income residents could not afford expensive housing in the new residential complexes. Moreover, they were offered little if any compensation for the loss of their living environment, whilst the availability of on-site public housing in Seoul used to be very limited. After completion of urban redevelopment, only a few among them returned to their neighborhoods, which resulted in extremely low resettlement rates (Kim and Yoon, 2003; Kim, 2010). At the same time, JRP and NTD contributed to growing rents and living costs around urban redevelopment areas, which additionally reduced the affordable housing supply in the city. Low-income residents had no choice but to leave their homes and make place for new, affluent residents.

The commodification of localities not only destroyed deprived residential areas and their social relationship networks, but also contributed to spatial fragmentation and social polarization in the city. JRP and NTD caused strong conflicts between the stakeholders over the use and meaning of localities. On the one hand, the residents struggled to protect their housing rights, while on the other hand, the landowners and construction corporations tried to maximize their profits through speculative investments on the property markets (Kim, 2010; Shin, 2018). Since the 1980s, a large amount of surplus capital was absorbed through JRP and NTD, which served the large investors and aspirations of the emerging middle class (Joo, 2019). For these reasons, the state facilitated commodification of localities through property-led urban redevelopment not only to improve the housing supply, but also to maintain support and strengthen legitimacy among large corporations and the affluent population (Shin and Kim, 2016; Cho and Križnik, 2017).

In the late 1990s, however, the negative consequences of property-led urban redevelopment on localities became more apparent and community engagement was recognized as a way to address the conflicts between the stakeholders (Jeong, 1999; Douglass, Ard-Am and Kim, 2001). With the introduction of NTD in 
2002, the state tried for the first time "to ensure the participation of residents and civic representatives in planning and initiating the multimillion-dollar project to curb real estate speculation" (SMG, cited in Cho and Križnik, 2017: 76). Wangsimni New Town, for instance, was among the first cases of community engagement, although the latter failed to have a significant impact on propertyled urban redevelopment. This was partly due to limited experiences with citizen participation at the time and partly due to redevelopment associations' attempts to render community engagement ineffective (Križnik, 2009). In the end, SMG decided to implement the project without citizen participation, which led to the demolition of the neighborhood, displacement of the residents, destruction of productive and social relationship networks and heightened social conflicts (Figure 5.1) (Križnik, 2018).

After 2008, SMG started to promote community engagement in planning and management of deprived residential areas to address the negative consequences of property-led urban redevelopment on localities in a more effective and comprehensive way. Several state-led urban regeneration projects were introduced over the past decade (Cho and Križnik, 2017; Kim, 2018b; Yu, 2018; Wolfram, 2019). These projects, however, cannot be applied everywhere in the city. Kim (2018a: 16) shows that the transformation of localities in Seoul continues to be "grounded in market forces and ultimately in profit ... no matter the negative impact on the urban space".

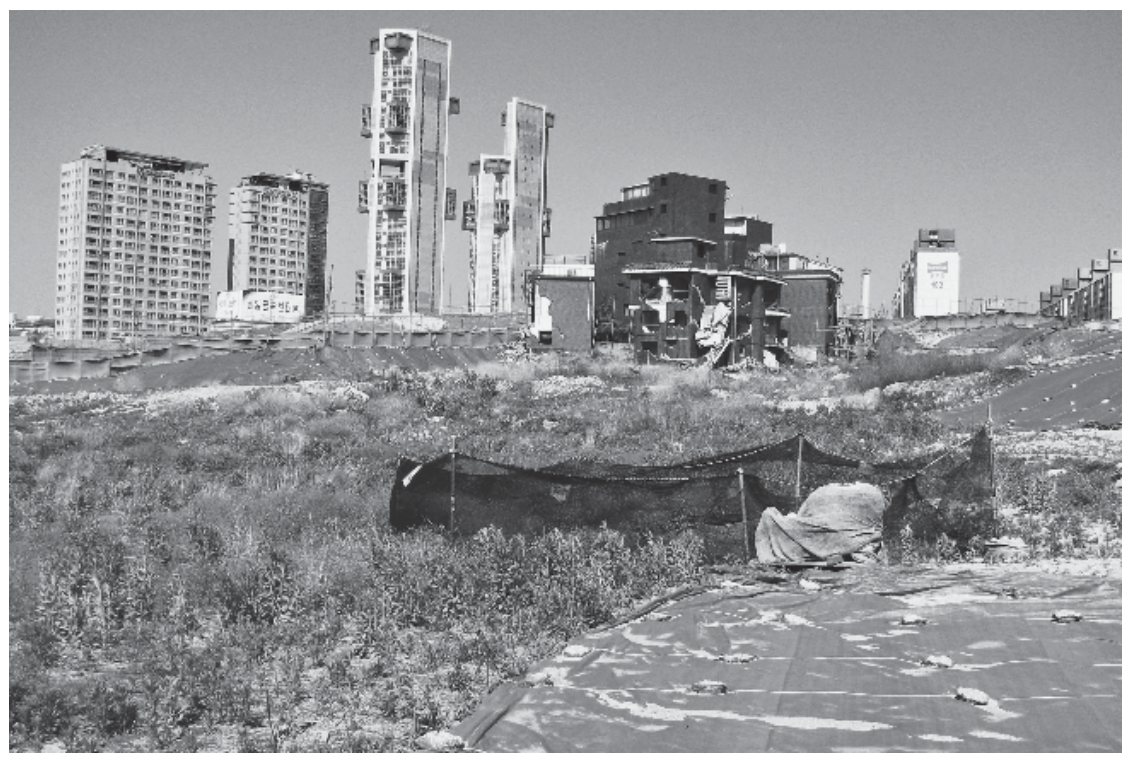

Figure 5.1 Property-led urban redevelopment and localities, Wangsimni New Town. Source: Choi Hongyi, 2011. 


\section{Localities and community engagement}

Transformation of localities, resulting from speculative investments on property markets, left little room for community engagement in the past. Marginalized social groups, such as the urban poor, low-income tenants and small landowners, were excluded from taking part in the property-led urban redevelopment. Instead, they faced forced evictions, displacement, demolition of their homes and loss of jobs and social relationship networks. Commodification of localities gave rise to grassroots struggles, which tried to protect the housing rights of marginalized social groups, alleviate poverty and unequal provision of jobs and services in deprived residential areas and recover communal life in localities (Cho, 1998; Jeong, 1999; Douglass, Ard-Am and Kim, 2001; Jeong, 2012; Kim and Lee, 2015; Kim, 2017a; Kim and Križnik, 2018; Shin, 2018). These place-based grassroots struggles largely evolved into community movements (jiyeoksahoeundong, maeulmandeulgiundong, maeulgongdongcheundong) as collective "actions voluntarily practised at the neighborhood or community level and aimed at improving the community's physical, relational or sociological aspects" (Kim, 2017b: 3808).

Urban poor movements (binminundong) and anti-eviction movements (toegeobandaeundong) represent early attempts to resist the commodification of localities (Jeong, 2012; Shin, 2018). Although grassroots struggles in Korean cities emerged as early as the 1950s, they were often short-lived (Kim and Lee, 2015 ). In the 1970s, however, some religious groups and experts became permanently engaged in alleviating the harsh living conditions of the urban poor in shantytowns (Douglass, Ard-Am and Kim, 2001; Jeong, 2012; Kim, 2017a). Anti-eviction movements emerged as a response to the massive demolition of deprived residential areas in the 1980s. The demolition gangs, which forcefully evicted the residents to clear the shantytowns for new urban development, were often assisted by the state. On the other hand, pro-democracy activists took part in anti-eviction movements, which increased their capacity to resist evictions and state oppression (Cho, 1998; Kim and Lee, 2015; Kim, 2017a). For these grassroots struggles, community engagement was not an aim in itself, but rather a "means of engaging and empowering the urban poor to improve their living environment and protect the housing rights" (Kim and Križnik, 2018: 235).

After the 1980s, the democratization of Korean society contributed to the emergence of civil movements (siminundong), which shifted attention from the national to local issues and "sought to transform the everyday life" (Katsiaficas, 2012: 413). In contrast to earlier urban poor and anti-eviction movements, the civil movements emerged in affluent residential areas and focused on issues such as gender inequalities, childcare and education, food safety, environmental degradation and local autonomy, as well as community restoration (Jeong, 2012; Kim and Lee, 2015). Community restoration and perceived loss of communal life became a major drive behind place-based grassroots struggles in the 1990s, while community engagement was considered as not only a way to resist the commodification of localities, but also an alternative to growing individualism 
and economic uncertainties in the aftermath of the IMF crisis. This has brought locality, its social relationship networks, and its shared meanings to the focal point of the emerging community movements (Kim, 2017b; Kim and Križnik, 2018; Shin, 2018).

Jeong (1999) identified more than a hundred cases of community movements in the late 1990s. These mostly took place as autonomous grassroots struggles, with little or no state involvement or support. After 1998, however, the state started to institutionalize citizen participation in the social and political life of the country, which was expected to strengthen the local autonomy and political legitimacy of the state (Kim, 2017b). The national and local governments provided financial and organizational support and built partnerships with civil society organizations, which increased their number and activities, improved their organizational capacity and contributed to the formation of nationwide coalitions and networks. This also applied to community movements, which were gradually institutionalized during the 2000s as formal community organizations (jiyeogsahoejojig) (Read, 2012; Kim and Lee, 2015; Kim, 2017b). Over time, place-based grassroots struggles continuously evolved from earlier urban poor and anti-eviction movements towards autonomous and increasingly institutionalized community movements (Table 5.1) (Jeong, 2012).

In Seoul, the first attempts to institutionalize community movements date back to the late 1990s and initially had various successes. A major change happened in 2012 when SMG recognized the importance of community engagement to resolve the mounting social and economic problems in the city by "making the neighbourhood community the centre of its policymaking" (2015: 240). Community engagement gradually became "one of the most impactful platforms with which to involve communities in shaping their built environments" (CLC and SI, 2017: 87). On the one hand, SMG (2015) launched Seoul Neighbourhood Community Support Centre to provide support for diverse grassroots efforts, aiming to restore communal life in the city (Ahn, Wi and $\mathrm{Yu}$,

Table 5.1 Evolving place-based grassroots struggles in Seoul

\begin{tabular}{|c|c|c|c|c|}
\hline & $1970-1980 s$ & $1990 s$ & $2000 s$ & $2010 s$ \\
\hline $\begin{array}{l}\text { Grassroots } \\
\text { struggles }\end{array}$ & $\begin{array}{l}\text { Urban poor } \\
\text { movements }\end{array}$ & $\begin{array}{l}\text { Anti-eviction } \\
\text { movements }\end{array}$ & $\begin{array}{l}\text { Autonomous } \\
\text { community } \\
\text { movements }\end{array}$ & $\begin{array}{l}\text { Institutionalized } \\
\text { community } \\
\text { movements }\end{array}$ \\
\hline Main aim & $\begin{array}{l}\text { Alleviation of } \\
\text { poverty }\end{array}$ & $\begin{array}{l}\text { Protection } \\
\text { of housing } \\
\text { rights }\end{array}$ & $\begin{array}{l}\text { Restoration of } \\
\text { communal life }\end{array}$ & $\begin{array}{l}\text { Expansion } \\
\text { of local } \\
\text { autonomy }\end{array}$ \\
\hline $\begin{array}{l}\text { State } \\
\quad \text { involvement }\end{array}$ & $\begin{array}{l}\text { Oppression } \\
\text { of the } \\
\text { community }\end{array}$ & $\begin{array}{l}\text { Struggles } \\
\text { with the } \\
\text { community }\end{array}$ & $\begin{array}{l}\text { Institutionalization } \\
\text { of the } \\
\text { community }\end{array}$ & $\begin{array}{l}\text { Partnerships } \\
\text { with the } \\
\text { community }\end{array}$ \\
\hline $\begin{array}{l}\text { Improvement } \\
\text { approach }\end{array}$ & \multicolumn{2}{|c|}{ Joint Redevelopment Project } & $\begin{array}{l}\text { New Town } \\
\text { Development }\end{array}$ & $\begin{array}{l}\text { Liveable Maeul- } \\
\text { making Pilot } \\
\text { Project }\end{array}$ \\
\hline
\end{tabular}


2016). On the other hand, community engagement became an integral part of state-led urban regeneration, which was to improve deprived residential areas by engaging residents in the planning and management of their living environment (Kim, 2018b; Yu, 2018). The following sections compare the transformation and community engagement in Songhak Maeul and Seowon Maeul in Seoul. ${ }^{4}$

\section{Case: community engagement in Songhak Maeul and Seowon Maeul}

\section{Songhak Maeul: grassroots struggles against urban redevelopment}

Songhak Maeul was built in 1995 to provide temporary housing for 378 residents in Haengdang-dong in central Seoul, who would otherwise have been displaced due to urban redevelopment in the Geumho-Haengdang-Hawang area (Hawang 2-1 District Tenants Rights Committee, 1995). ${ }^{5}$ With 102 housing units, it was not only the largest but also the most active and representative case of community engagement in the area (Kim, 2017a). The beginning of community movement, however, dates back to 1987, when two community activists settled in Haengdang-dong, which used to be one of the largest shantytowns in central Seoul at that time. With the help of religious organizations and student volunteers, community activists managed to organize diverse communal activities, which not only helped in alleviating poverty but also strengthened social relationship networks among the residents in Haengdang-dong (Cho, 1998; Kim, 2017a).

Amid these efforts, Haengdang-dong was selected for JRP in 1993, which led to the demolition of the entire locality, displacement of the residents and construction of a new residential complex with 11,032 housing units (Cho, 1998). The massive property-led urban redevelopment has brought significant financial gains to the landowners and construction corporations, while little attention was paid to the needs of the tenants, who represented the majority of the population. Only 18 percent of households in Haengdang-dong owned their homes in 1990 (SDI, 1994). Soon after the project was announced, about 60 percent to 70 percent of the landowners evicted the tenants to proceed with urban redevelopment as fast as possible (Kim, 2017a). The tenants were offered either a small compensation or public rental housing in the new residential complex and had to move out of Haengdang-dong. Finding a new home was particularly difficult for the tenants, whose livelihood depended on jobs in the local textile, metal or construction industries (Križnik, 2009).

For this reason, about 350 households struggled to stay in Haengdang-dong "to recognize their basic human rights to a sustainable way of community life" (Cho, 1998: 102). In order to protect their housing rights, they established the Tenants Rights Committee (Seipjadaechaekwiwonhoe, TRC), which played the key role in resisting forced evictions between 1993 and 1994 (Figure 5.2) (Hawang 2-1 District Tenants Rights Committee, 1995). These evictions were violently carried out by the redevelopment associations and construction 


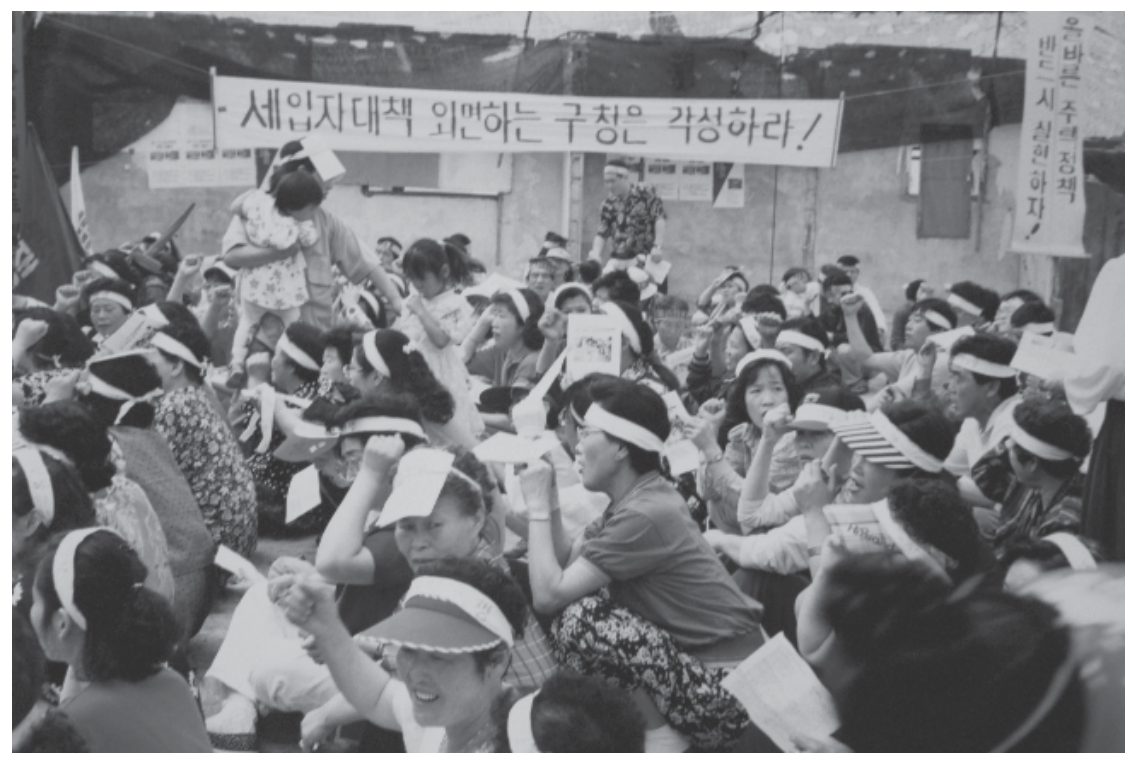

Figure 5.2 Community struggles against forced evictions in Haengdang-dong.

Source: Seongdong Residents Association, 1994.

corporations and were supported by the state, which considered JRP a muchneeded way to improve the housing shortage in the city. The TRC was left with no choice but to struggle for the provision of temporary housing, which would allow the tenants to stay in Haengdang-dong during the urban redevelopment. These struggles eventually led to the construction of Songhak Maeul in 1995, where the tenants lived until they moved to the new public rental housing in 1999 (Kim and Križnik, 2018).

Struggles against forced evictions not only helped to protect their housing rights but also strengthened solidarity among the tenants and improved their organizational capacity. In 1995, the tenants established the GeumhoHaengdang-Hawang Planning Committee (Geumho-Haengdang-Hawangjiyeok Gihoekdan) to plan and manage communal activities in the new temporary facilities. In Songhak Maeul, these included communal childcare (Onsundonsun noribang, Songhak noribang), after-school and evening education (Haengdang baeumteo, Mindeulle gongbubang), cultural festivals (Jumin danohanmadang), producer and consumer cooperatives (Nongol uiryusaengsanhyeopdongjohap, Songhak gupanjang) and a credit union (Nongol sinyonghyeopdongjohap) (Kim, 2017a). These community organizations were instrumental in sustaining community engagement and in expanding the self-reliance of the community movement in Songhak Maeul. The latter was also a result of collaboration with other community movements and advocacy groups, experts and NGOs. After 
1997, the planning committee also started to collaborate with the state through the Citizens' Committee for Green Seoul (Noksaekseoulsiminwiwonhoe) (Kim, 2017a).

Many residents arrived at the new residential complex after the completion of JRP in 1999. The population of Haengdang-dong increased from 9,392 in 1998 to 28,966 in 2000 , while house-ownership increased from 18 percent to 40 percent (SDI, 1994, 2002; SMG, 2000). The newcomers mostly belonged to middle-income households and used to have little relations with the low-income residents in the public rental housing. This social gap and emerging conflicts between the former residents of Songhak Maeul contributed to a decline in community engagement. In the mid-2000s, however, Songhak Maeul community activists launched the Seongdong Residents Association (Seongdongjuminhoe) to strengthen community engagement in improving everyday life and local autonomy (Kim, 2017a). The Nongol Credit Union provided financial and organizational support that helped in sustaining communal activities in the following years. With their roots in the community movement in Songhak Maeul, the Nongol Credit Union and Seongdong Residents Association remain the most important community organizations in Haengdang-dong as of today.

\section{Seowon Maeul: urban regeneration and community engagement}

Seowon Maeul is a small residential area in Amsa-dong on the periphery of eastern Seoul. It had 365 residents and 165 households when the urban regeneration started in 2009 (SMG, 2010b). Its origin, however, dates back to 1979, when Jeom Maeul was built through a living environment improvement project (Jang, 2012). Over the years, its peripheral and isolated location, poor accessibility and small size, as well as aging population contributed to the formation of a comparatively strong and well-off community. The majority of the residents owned their houses, which they lived in for decades. They used to share food, help each other and hold regular neighborhood meetings (bansanghoe) in the old community center (Yu, 2018). ${ }^{6}$ These meetings started to take place more frequently after the construction of the nearby Amsa Bridge was announced. Due to concerns that the bridge would deteriorate the quality of the living environment and contribute to a decline of property values, a small group of residents launched the Maeul Development Committee (Maeulbaljeonwiwonhoe, MDC) in 2005 (Jang, 2012). Moreover, restrictive building regulations, which were put in place because of the nearby historical monument and large infrastructure, negatively affected the quality of the living environment and property values in Seowon Maeul (Kim and Križnik, 2018).

The MDC tried to convince the state to relax the building regulations and tried to improve the negative identity of Jeom Maeul by changing its name to Seowon Maeul in 2007 (Jang, 2012). In late 2008, Seowon Maeul was selected as one of the LMPP pilot projects, for its seemingly declining living environment, lack of appropriate social amenities and infrastructure, and restrictive building regulations, as well as its existing social relationship networks (SMG, 2010b). 
The MDC actively supported and promoted urban regeneration among the residents, which was expected to improve the living environment and property values in the locality (CLC and SI, 2017).

LMPP aimed to improve deprived residential areas with detached multi-family houses, by improving existing and providing new social amenities and infrastructure, supporting the homeowners to renovate their houses, and restoring communal life in localities (SMG 2010b, 2011). Moreover, it aimed to improve the organizational capacity of the residents to plan and manage communal activities through their participation in decision-making. In this sense, urban regeneration in Seowon Maeul can be considered an early approach, addressing the improvement of deprived residential areas in Seoul through citizen participation in planning and decision-making (Cho and Križnik, 2017). The planning process took place from 2009 to 2010 and the construction started in early 2011 (SMG, $2010 \mathrm{~b})$. Surveys and interviews with the residents, public presentations and community workshops were extensively used to engage the residents in planning "design guidelines for parks, community centres, parking issues and residential properties" (Figure 5.3) (CLC and SI, 2017: 103).

Community workshops turned out to be important not only for planning but also for building trust between the residents, experts and public officials (Jang, 2012; Yu, 2018). Some residents initially opposed the project, raising concerns that LMPP would additionally restrict urban development and contribute to a

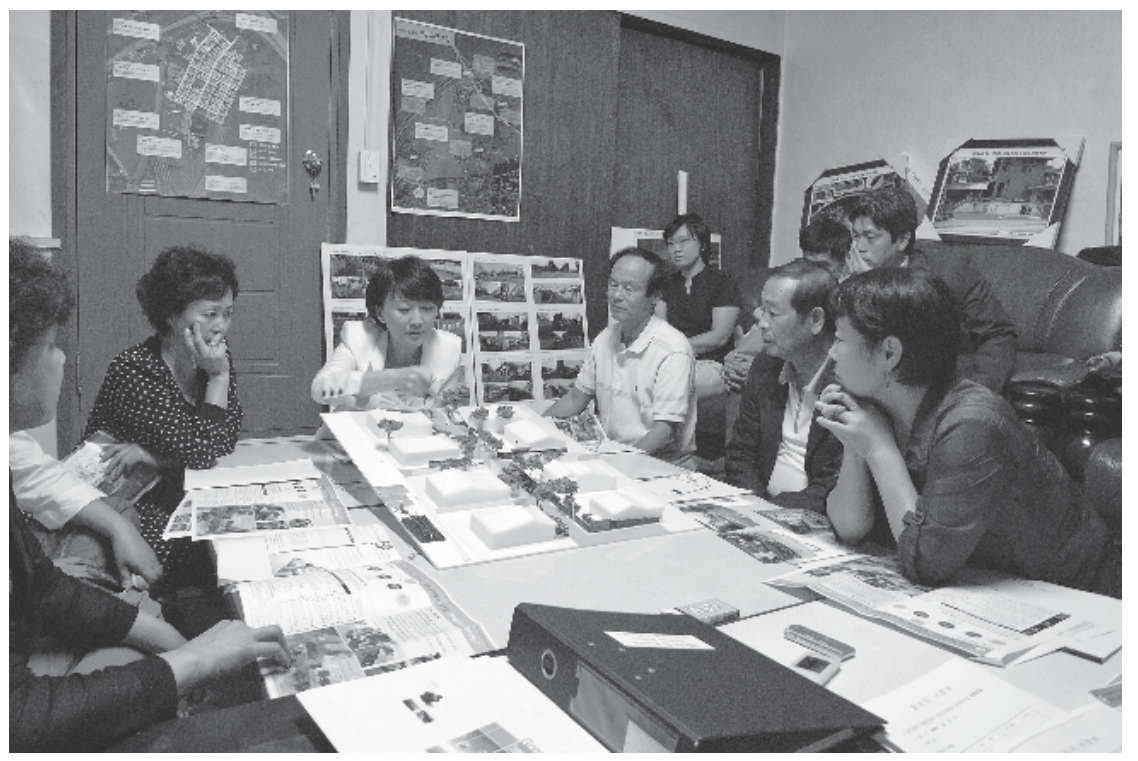

Figure 5.3 Community engagement in planning, Seowon Maeul.

Source: PMA, Place Making Associates, 2010. 
decrease of the property values. Through community engagement, however, they recognized the importance of urban regeneration for improving the living environment and for restoring communal life in the locality. In 2010, 86 percent of the residents voted in favor of stricter rather than more flexible building regulations (SMG, 2011: 218). In this way, the residents decided to preserve the existing living environment rather than promote a more profitable urban redevelopment. They also adopted Seowon Maeul Residents' Commitment (Seowon Maeul juminyaksok), which formalized residents' decision to voluntarily improve private houses and gardens (CLC and SI, 2017). At the same time, they collaborated with public officials and built a partnership with the local government. As a result, a new community center with a public library and community space was built, streets and private gardens were remodeled, and new parking spaces, small parks and children's playgrounds were constructed (SMG, 2010b). ${ }^{7}$

Another important result of LMPP was the institutionalization of community movement in Seowon Maeul. The residents, who had previously taken part in neighborhood meetings, MDC or local Women's Association (Bunyeohoe), played an important role in establishing the Seowon Maeul Residents Committee (Seowon Maeul juminhyeobuiche) in 2009. In 2012, the committee launched the Seowon Maeul Residents Community Management Committee (Seowon Maeul jumingongdongche unyeongwiwonhoe, RCMC), which is nowadays the main community organization, managing communal activities, such as weekly events for the children and elderly, monthly neighborhood meetings, and occasional community workshops and festivals. Seowon Maeul has become recognized as a successful case of state-led urban regeneration in Seoul (CLC and SI, 2017; Yu, 2018).

\section{Comparison: community movements and the state}

The transformations of Songhak Maeul and Seowon Maeul represent different approaches, addressing improvement of deprived residential areas in Seoul. The former is a case of property-led urban redevelopment (JRP), while the latter represents a state-led urban regeneration (LMPP). Songhak Maeul and Seowon Maeul are also important cases of community movements in Seoul. They are among the few localities in the city, where community engagement has been sustained continuously for more than a decade. Since the late 1980s, community movement in Songhak Maeul has evolved from an urban poor and antieviction movement to an autonomous community movement (Cho, 1998; Kim and Lee, 2015; Kim, 2017a). Community movement in Seowon Maeul has also been active for almost two decades (Jang, 2012; Kim and Križnik, 2018; Yu, 2018). The following is a comparison of Songhak Maeul and Seowon Maeul in terms of their characteristics, transformation and its consequences on locality, state involvement and state-community relationship, and evolution of community movement (Table 5.2).

Songhak Maeul and Seowon Maeul used to be relatively deprived residential areas, although strong social relationship networks existed in each locality before 
Table 5.2 Comparison of community movements in Songhak Maeul and Seowon Maeul

\begin{tabular}{|c|c|c|}
\hline & Songhak Maeul & Seowon Maeul \\
\hline Location & $\begin{array}{l}\text { Haengdang-dong } \\
\text { (Seongdong-gu, Seoul) }\end{array}$ & $\begin{array}{l}\text { Amsa-dong } \\
\text { (Gangdong-gu, Seoul) }\end{array}$ \\
\hline $\begin{array}{l}\text { Characteristics of } \\
\text { locality }\end{array}$ & $\begin{array}{l}\text { Marginalized urban poor area } \\
\text { with strong communal life }\end{array}$ & $\begin{array}{l}\text { Peripheral well-off area with } \\
\text { strong communal life }\end{array}$ \\
\hline $\begin{array}{l}\text { Transformation of } \\
\text { locality }\end{array}$ & $\begin{array}{l}\text { Property-led urban } \\
\text { redevelopment (JRP) }\end{array}$ & $\begin{array}{l}\text { State-led urban regeneration } \\
\text { (LMPP) }\end{array}$ \\
\hline $\begin{array}{l}\text { Consequences on } \\
\quad \text { locality }\end{array}$ & $\begin{array}{l}\text { Demolition of locality, } \\
\text { displacement of residents, } \\
\text { heightened social conflicts }\end{array}$ & $\begin{array}{l}\text { Preservation of locality, no } \\
\text { displacement of residents, } \\
\text { limited social conflicts }\end{array}$ \\
\hline State involvement & $\begin{array}{l}\text { Facilitates urban redevelopment, } \\
\text { oppresses the community }\end{array}$ & $\begin{array}{l}\text { Leads urban regeneration, } \\
\text { builds a partnership with the } \\
\text { community }\end{array}$ \\
\hline $\begin{array}{l}\text { Community } \\
\text { movement }\end{array}$ & $\begin{array}{l}\text { Urban poor and anti-eviction } \\
\text { movement evolves into } \\
\text { autonomous community } \\
\text { movement }\end{array}$ & $\begin{array}{l}\text { Institutionalization of } \\
\text { autonomous community } \\
\text { movement }\end{array}$ \\
\hline
\end{tabular}

Source: Adapted from Kim and Križnik (2018: 237)

their transformation. There were, however, significant differences between them regarding their social and economic structure and living environment. Songhak Maeul used to be located in one of the poorest shantytowns in central Seoul. In contrast, Seowon Maeul was a well-off residential area, located on the periphery of the city. While poor tenants lived in the former, the residents of the latter were mostly landowners (Jang, 2012; Kim, 2017a; Yu, 2018). Their transformation followed a different approach and had rather different consequences on the locality. In Songhak Maeul, the property markets were the major drive behind the transformation that resulted in a full-scale demolition of the living environment, forced evictions and displacement of the residents, heightened social conflicts and construction of a new residential complex. In contrast, the living environment in Seowon Maeul was not demolished but preserved and gradually improved, although a declining property market and social conflicts also played a role in the transformation of the locality.

Urban redevelopment in the Geumho-Haengdang-Hawang area was carried out in a partnership between the landowners' redevelopment associations and construction corporations with little state involvement in planning and implementation of JRP (Cho, 1998). The state, nevertheless, oppressed the community, facilitated forced evictions of the residents and did little to protect their housing rights. The residents consequently perceived the local government as what they called "the bad guys" (Kim and Križnik, 2018). In contrast to Songhak Maeul, state involvement was instrumental for the planning and implementation of LMPP in Seowon Maeul. Moreover, the state considered citizen participation to be the key to successful urban regeneration and tried to build a partnership with the community $(\mathrm{Yu}, 2018)$. Although a lot of mistrust between the residents 
and the local government existed in the beginning, their relationship has evolved into what the residents described as a mutual "give-and-take relationship" (Kim and Križnik, 2018).

The entirely different state-community relationship had a significant impact on community engagement in each locality. The adversarial relationship in Songhak Maeul led to the formation of autonomous community movement. Grassroots struggles to alleviate poverty, fighting against the forced evictions and protecting their housing rights have strengthened social relationship networks, solidarity and shared meanings among the residents, who remembered those early struggles as harsh but "the most meaningful experience of being together" (Kim, 2017a: 408). Community movement in Songhak Maeul built strong and self-reliant community organizations, as well as coalitions with other community movements and civil society organizations, which became instrumental in sustaining community engagement and contributed to community empowerment and the expansion of local autonomy over time.

In Seowon Maeul as well, existing social relationship networks affected early grassroots struggles to improve the living environment and led to the formation of autonomous community movement. Yet, it was not the community movement but the state-led urban regeneration that strengthened "trust, a sense of community and good communication between residents" (CLC and SI, 2017: 108). The state built a partnership with the community through workshops and community organizations, which sustained community engagement and contributed to community empowerment in Seowon Maeul. At the same time, the institutionalization of community movement heightened its reliance on the state and restricted community engagement to the transformation of locality. Strong self-reliance and participation in the nationwide grassroots struggles and coalitions, to the contrary, helped in expanding community engagement in Songhak Maeul "beyond local symptoms to the structural causes of oppression" which Ledwith (2011: xv) sees as key to "radical community development". In this way, community movement in Songhak Maeul contributed not only to the transformation of locality, but also to broader social and urban change in the city.

\section{Conclusion}

This chapter examines the changing relation between the state, property markets and community and their role in the transformation of localities and urban development in Seoul. A comparison of different approaches, addressing the improvement of deprived residential areas, shows that property markets used to be the major drive behind the transformation of localities. Although these approaches improved housing provision and the living environment in the city, they also resulted in the demolition of deprived residential areas, displacement of the residents, heightened social conflicts, destruction of social relationship networks and decline of communal life in localities. Property-led urban redevelopment turned localities into commodities and stripped them of their histories and shared 
meanings. While the state used to facilitate accumulation of capital through the commodification of localities, it has also recognized its negative consequences and started to promote state-led urban regeneration to improve the living environment and restore communal life in the city. The changing state involvement in the transformation of localities had a significant impact on the state-community relationship and community engagement, which is now considered as the key to successful improvement of deprived residential areas in Seoul.

The comparison of Songhak Maeul and Seowon Maeul, however, also reveals the importance of grassroots struggles for the transformation of localities, despite significant differences between both cases. While the role of the state in building partnerships with the community is important, the significance of grassroots struggles for the transformation of localities and urban development in Seoul should not be overlooked. The recent surge of community movements in the city cannot be attributed only to the state involvement in expanding community engagement and providing support for the grassroots to recover communal life in localities. It is also related to the long history of grassroots struggles in Korea, which challenged the state and struggled against the commodification of localities. Recognizing localities as sites of community engagement could contribute to a more comprehensive understanding of urban development and international development cooperation in Korea, as their success has often been attributed to the state and property markets without much consideration of the state-community relationship in building sustainable cities.

\section{Acknowledgments}

The authors wish to thank Yu Youngwoo and Yu Na Kyoung for their generous help with the research. Furthermore, the authors wish to thank Yoon Keumhee for her assistance in preparing this chapter.

\section{Notes}

1 This chapter draws on earlier research, which the authors conducted and published over the past years (Kim and Križnik, 2018; Križnik, Cho and Kim, 2019). Their research was largely based on a case-oriented qualitative research approach, where primary data were collected through site visits, participant observation and in-depth interviews with residents, members of community organizations, experts and public officials. Primary data were complemented and contextualized with an analysis of relevant policies, research reports, journal articles and other secondary resources, related to community engagement and urban development in Seoul.

2 Park (1998: 277) reported that in Korea, the government expenditure for public housing was less than 1 percent of the national budget in 1986, while Singapore, known for successful public housing, spent about 14 percent of its national budget for housing in the same year.

3 In Korea, urban redevelopment aims to improve deprived residential areas by demolishing existing neighborhoods and building new residential complexes. In contrast, urban regeneration refers to gradual and comprehensive improvement rather than demolition of deprived residential areas (Križnik, 2018). 
$4 \mathrm{Maeul}$ refers not only to a particular geographic area, but also to social and economic relations, practices, histories and shared meanings embedded in a locality. In regard to community movements, maeul can also carry transformative connotations and cannot be translated simply as a village, town or neighborhood (Kim and Križnik, 2018). For these reasons, the authors prefer the Korean word maeul to its English translation.

5 Haengdang-dong refers to the administrative district of Haengdang 2-dong in Seongdong-gu, Seoul. Apart from Haengdang 2-dong, the JRP also affected Geumho 1-dong, Haengdang 1-dong, and Wangsimni 2-dong (former Hawangsimni-dong).

6 The state introduced neighborhood meetings in 1976 to "bring together at least one member of every household in the country on the twenty-fifth of every month, solidifying national unity within grassroots gatherings" (Read, 2012: 154). Initial state control has relaxed over the time and the bansanghoe meetings became increasingly irregular and voluntary by the early 2000 s.

7 After 2010, LMPP proceeded as a Seoul Human Town and Residential Environment Management Project, which, however, changed little in terms of its aims, planning approach or implementation (Yu, 2018).

\section{References}

Ahn, H., S. Wi and C. B. Yu (2016). Neighbourhood Community. Seoul: The Seoul Institute (in Korean).

Castells, M. (1983). The City and the Grassroots: A Cross-Cultural Theory of Urban Social Movements. Berkeley: University of California Press.

Castells, M. (1992). "Four Asian Tigers with a Dragon Head: A Comparative Analysis of the State. Economy, and Society in the Asian Pacific Rim," in R. P. Appelbaum and J. Henderson (eds.), States and Development in the Asia Pacific Rim. London: Sage, pp. 33-70.

Chang, Y., W. Nam and C. Lee (2018). Coping with Housing Demand: Experience of Seoul. Seoul: The Seoul Institute.

Cho, I. S. and B. Križnik (2017). Community-based Urban Development, Evolving Urban Paradigms in Singapore and Seoul. Singapore: Springer Nature.

Cho, M. R. (1998). "Progressive Community Movements in Korea: The Case of the Hangdang Redevelopment Area in Seoul," International Journal of Urban Sciences 2(1), pp. 92-109.

CLC and SI (2017). Planning for Communities, Lessons from Seoul and Singapore. Singapore: CLC.

Cohen, A. P. (1985). The Symbolic Construction of Community. London: Ellis Horwood and Tavistock Publications.

Day, G. (2006). Community and Everyday Life. Abingdon: Routledge.

Douglass, M., O. Ard-Am and I. K. Kim (2001). "Urban Poverty and the Environment: Social Capital and State-Community Synergy in Seoul and Bangkok," in P. Evans (ed.), Livable Cities? The Politics of Urban Livelihood and Sustainability. Berkeley: University of California Press, pp. 31-66.

Harvey, D. (2001). Spaces of Capital. Towards a Critical Geography. New York: Routledge. Harvey, D. (2012). Rebel Cities. From the Right to the City to the Urban Revolution. London: Verso.

Hawang 2-1 District Tenants Rights Committee (1995). Together in Harmony towards the Community. Seoul: Hawang 2-1 District Tenants Rights Committee (in Korean).

Hodkinson, S. (2012). “The New Urban Enclosures," City 16(5), pp. 500-518.

Jang, G. T. (2012). "Making of Liveable Seowon Maeul," Review of Architecture and Building Science 56(6), pp. 46-50. 
Jeong, K. H. (2012). "Development of the Korean Urban Community Movement and the Meanings of Collaborative Model," Korean Studies Quarterly 35(2), pp. 7-34 (in Korean).

Jeong, S. (1999). Basic Guidelines for the Implementation of Neighbourhood Unit Urban Plan: A Case Study of Residents' Participatory Community Building. Seoul: SDI (in Korean).

Joo, Y. M. (2019). Megacity Seoul: Urbanization and the Development of Modern South Korea. Abingdon: Routledge.

Katsiaficas, G. N. (2012). Asia's Unknown Uprisings. Volume 1, South Korean Social Movements in the 20th Century. Oakland: PM Press.

Kim, J. H. (2017a). "Unrealised Dream, Moving Again towards Community. In: Publishing Committee for the History of Urban Poor Areas," in Searching for the Origin of Neighbourhood Community Movements. Seoul: Hanul, pp. 107-159 (in Korean).

Kim, K. J. and I. S. Yoon (2003). "Urban Renewal and Change of the 20th Century Seoul," in K. J. Kim (ed.), Seoul, Twentieth Century: Growth \& Change of the Last 100 Years. Seoul: Seoul Development Institute, pp. 543-596.

Kim, S. (2017b). "From Protest to Collaboration: The Evolution of the Community Movements Amid Sociopolitical Transformation in South Korea," Urban Studies 54(16), pp. 3806-3825.

Kim, S. H. (2018a). "High Density Dilemmas: Apartment Development vs. Urban Management Plan in Seoul," Seoul Studies 19(4), pp. 1-20.

Kim, S. H. (2018b). "A Theory of Planned Behaviour Approach to Neighbourhood Community Engagement in Samdeok Town, Seoul," Master Thesis, Seoul: Seoul National University (in Korean).

Kim, S. and B. Križnik (2018). "Civic Urbanism and the State: Transition of the State Involvement in Community Building in Seoul, South Korea", in GASS/PRCDNET/ SFI 2018 (ed.), Emerging Civic Urbanisms/Designing for Social Impact. Singapore: National University of Singapore, pp. 228-252.

Kim, S. H. (2010). "Issues of Squatters and Eviction in Seoul: From the Perspectives of the Dual Roles of the State," City Culture and Society 1(3), pp. 135-143.

Kim, S. K. and C. E. Lee (2015). Maeul Built Together, Life Enjoyed Together. Seoul: Korea National Open University Press (in Korean).

Križnik, B. (2009). Local Responses to Global Challenges: Cultural Context of Urban Change in Barcelona and Seoul. Ljubljana: FDV Press (in Slovene).

Križnik, B. (2018). "Transformation of Deprived Urban Areas and Social Sustainability: A Comparative Study of Urban Regeneration and Urban Redevelopment in Barcelona and Seoul," Urbani Izziv 29(1), pp. 30-41.

Križnik, B., I. S. Cho and S. Kim (2019). "Deciding Together: Citizen Participation in Planning the Neighbourhood Improvement in Seoul and Singapore," Asia Review $8(2)$, pp. 65-102.

Lash, S. (1994). "Reflexivity and Its Doubles: Structures, Aesthetics and Community," in U. Beck, A. Giddens and S. Lash (eds.), Reflexive Modernization: Politics, Tradition and Aesthetics in the Modern Social Order. Cambridge: Polity Press, pp. 110-173.

Ledwith, M. (2011). Community Development, a Critical Approach. Bristol: Policy Press. Lefebvre, H. (2003). Urban Revolution. Minneapolis: University of Minnesota Press.

Manzi, T., K. Lucas, T. L. Jones and J. Allen (2010). Social Sustainability in Urban Areas: Communities, Connectivity, and the Urban Fabric. London: Earthscan.

Massey, D. (1994). Space, Place and Gender. Minneapolis: University of Minnesota Press.

Park, B. G. (1998). "Where Do Tigers Sleep at Night? The State's Role in Housing Policy in South Korea and Singapore," Economic Geography 74(3), pp. 272-288. 
Park, W. S. (2014). "In Seoul, the Citizens Are the Mayor," Public Administration Review 74(4), pp. 442-443.

Read, B. L. (2012). Roots of the State: Neighborhood Organization and Social Networks in Beijing and Taipei. Palo Alto: Stanford University Press.

Robson, T. (2000). The State and Community Action. London: Pluto.

Sassen, S. (2017). “The City: A Collective Good?” The Brown Journal of World Affairs 23(2), pp. 119-126.

SDI (1994, 2000). Thematic Maps of Seoul. Seoul: SDI (in Korean).

Shin, H. B. (2018). "Urban Movements and the Genealogy of Urban Rights Discourses: The Case of Urban Protesters against Redevelopment and Displacement in Seoul, South Korea," Annals of the American Association of Geographers 108(2), pp. 356-369.

Shin, H. B. and S. H. Kim (2016). "The Developmental State, Speculative Urbanisation and the Politics of Displacement in Gentrifying Seoul," Urban Studies 53(3), pp. 540-559.

Short, J. R. and Y.-H. Kim (1998) "Urban Crises/Urban Representations: Selling the City in Difficult Times," in T. Hall and P. Hubbard (eds.), The Entrepreneurial City: Geographies of Politics, Regime and Representation. Chichester: John Wiley and Sons, pp. 55-75.

SMG (2010a). Seven Years of New Town Development. Seoul: SMG (in Korean).

SMG (2010b). Seoul Human Town, Type-1 District Unit Plan for Seowon Maeul. Seoul: SMG (in Korean).

SMG (2011). Liveable Maeul-making: Guidelines for Participatory Urban Design with Residents. Seoul: SMG (in Korean).

SMG (2015). White Paper on Neighborhood Communities of Seoul: Seoul, Life and People. Seoul: SMG.

SMG (1998, 2000, 2018). Seoul Statistical Yearbook 1998, 2000, 2018. Seoul: SMG.

Smith, N. (2002). "New Globalism, New Urbanism: Gentrification as Global Urban Strategy," Antipode 34, pp. 427-450.

Somerville, P. (2016). Understanding Community: Politics, Policy and Practice, 2 nd edition. Bristol: Policy Press.

Wolfram, M. (2019). "Assessing Transformative Capacity for Sustainable Urban Regeneration: A Comparative Study of Three South Korean Cities," Ambio 48(5), pp. 478-493.

Yu, N. K. (2018). "From Seoul Human Town to Urban Regeneration: The Case of Seowon Village," in SMG (ed.), Seoul Urban Regeneration Policy Brief. Seoul: Seoul Urban Regeneration Support Center, pp. 22-26 (in Korean). 
$\because$ Taylor \& Francis Taylor \& Francis Group http://taylorandfrancis.com 


\section{Part II}

Modeling the Korean urban development experience 
$\because$ Taylor \& Francis Taylor \& Francis Group http://taylorandfrancis.com 


\title{
6 Export urbanism \\ Asian emerging donors and the politics of urban development knowledge sharing
}

\author{
Jamie Doucette and Farwa Sial
}

\section{Introduction: urban knowledge sharing and Asian emerging donors}

One of the much-debated issues in development studies over the past decade has been how to understand the role of what appear, at first glance, to be "new" donors in the field of international development cooperation. The rise of China as a major global actor and economic powerhouse, the persistent critique of neoliberalism and the Washington Consensus, and the (now receding) pink tide in Latin America all hastened the search for alternative development models and have lent to the attractiveness of new donor countries. This search has raised both hope and fears about the benefits of new forms of development cooperation and the lessons they might bring (Mawdsley, 2012). For some, the rise of South-South Development Cooperation (SSDC) represents an historic opportunity to bypass conventional aid circuits and create more egalitarian and reciprocal relations between countries. While for others, it risks replicating older forms of imperialism, dependency and unequal exchange. While South Korea (hereafter Korea) is not a Southern donor per se, its development cooperation policies position it as a bridge between SSDC and traditional donors within this broad search for development alternatives and desire for reciprocal learning and exchange (Kim and Garland, 2019). Despite being the newest member of the OECD Development Assistance Committee (DAC), the script that follows Korean development cooperation contains a similar normative framing to that which has accompanied other emerging donors and actors within SSDC: it positions its aid as primarily demand-led, rejects conditionality, respects country "ownership", and models its aid policies on its own development experience. These features mark Korea as an "Asian emerging donor" (Stallings and Kim, 2017), for while Korea has joined the traditional donor club, these normative dimensions and the strong regional focus to its aid differentiate it from other members of the DAC, with the exception, perhaps, of Japan (Watanabe, 2018). Moreover, Korea continues to bare other features associated with emerging donors such as aid fragmentation, the strong effects of political leadership on aid policies and a strategic overlapping and regionalization of aid and investment flows (Mawdsley, Kim and Marcondes, 2017). 


\section{Jamie Doucette and Farwa Sial}

A key feature of emerging donors is their self-referential model of knowledge sharing: that is, the modeling of their cooperation policies on their past histories of development. This act of self-referencing can potentially serve as a mechanism for sharing practical knowledge, if adequately contextualized to the needs of developing countries; however, its also risks becoming a nationalist celebration and/or an overly culturalist understanding of development (Han, 2015; Watanabe, 2018). Korea's knowledge sharing efforts share this self-referential perspective as well as its ambivalent standpoint. As part of its development cooperation policies, for much of the past 15 years Korea has invested in "modularizing" its development experience in order to render it into a series of lessons for its cooperation partners. The guiding belief here has been that the Korean "model" itself can be broken down into discreet national policy narratives and re-assembled as a package based on demand from recipient countries. In interviews conducted in our own research on Korea's ambitious "Knowledge Sharing Program" (KSP)—the program that produces the master policy narratives that are used to delineate the Korean development experience and provide prescriptions for developing countries based upon it-and related cooperation policies, officials seem to vacillate on the extent to which narratives are transferable. Some argue that they are examples of best practice that can be transferred to recipient countries relatively easily, while others see them as sources of inspiration-as a development "alternative" rather than a development "model"-and express caution about the authoritarian context of the Korean development experience.

As the KSP's “modularization" project has recently been renamed as "context studies", it may be that, indeed, a more contextual standpoint has become popular among Korean development practitioners. Regardless of its name change, however, this work of policy narration and the Knowledge Sharing Program itself continues to expand. More recently, the Korean government has undertaken a more conscious effort to render its urban development experience into a series of legible lessons for countries to learn from. Perhaps mirroring the renewed emphasis on urbanization by the World Bank and other multi-lateral organizations, we might posit that there is indeed also an increasing explicit urban turn within Asian emerging donors' development cooperation policies. We describe this recent effort here as "explicit" and "more conscious" only because urban development already figures prominently in Korea's development cooperation and knowledge sharing initiatives in a de facto manner. For instance, the creation of water, energy, and transportation infrastructures, industrial complex development, housing finance, smart city development and land expropriation and compensation policy are all topics that have been shared through Korea's bilateral knowledge sharing and development cooperation programs (see Table 6.1).

In short, Korea already has an urban package of development assistance in the form of existing infrastructure, governance and agricultural assistance, even if it is not consciously recognized as an "urban" model of development cooperation as such. Korea's authoritarian-era rural modernization program, the New Village Movement-long touted as a solution to urban-rural inequality, and, in 
Table 6.1 Examples of bilateral KSP consultations concerning urban development

Support for Urban Transport Planning For Sustainable Cities in Columbia 2017/2018

Technology Transfer, Manufacturing Urban Planning in Ethiopia 2016/2017

Public-Private Partnership for Urban Transport Infrastructure in Columbia 2016/2017

Support for Urban Sustainable Urban Railway in Ho Chinh City 2016/2017

Green Urban Infrastructure: Solid Waste Management in Sri Lanka 2014

Research Institute of Urban and Housing Sector in Paraguay 2018/2019

Strengthening National Innovation System (NIS) for Effective Industrial

Transformation in Ethiopia 2019/2020

Policy Recommendation for Developing Industrial Parks in Cuba 2017/2018

Special Economic Zones: What can Developing Countries learn from the Korean

Experience? 2016/2017

practice, a policy that represented further integration of the rural into the urban through increases in agricultural productivity, migration and mechanizationcontroversially came to represent Korea's meta-brand of development assistance under now impeached President Park Geun-hye. In addition, Korea's public corporations and large conglomerates have long been active in helping to build urban-industrial infrastructure overseas, and can in ways be regarded as having helped to stimulate residential, industrial complex development and other production platforms in Southeast Asia and the Global South alongside official aid flows (see Potter, this volume). This broader aid/investment nexus contextualizes Korea's development cooperation policies and has long had an urban-industrial focus. Finally, to make this urban turn more explicit-perhaps inspired by China's own Belt and Road Initiative (BRI) (Williams, Robinson and Bouzarovski, 2019) - the Korean government has recently placed greater emphasis on exporting combined urban development and launched a new "Global Plant, Infrastructure and Smart City" (PIS) fund to do so. The fund integrates its urban capabilities in energy infrastructure, industrial complex and smart city design to produce an "export model" that combines the "entire city development process" (MLIT, 2019).

Regardless of the extent to which the narratives that circulate with/as development cooperation replicate a celebratory nationalism or simply provide contextual study, what is interesting about this recent effort is that it is not predominantly based on decentralized, city-to-city knowledge flows such as that which have characterized urban policy mobilities in other parts of the globe. While Korean cities have adopted their own ODA policies-part and parcel of wider efforts to promote development cooperation at multiple scales - the broader development knowledge sharing agenda has largely been supervised and executed by elite ministries and state agencies and institutes such as the Ministry of Economy and Finance and Korean Development Institute. In other words, the urban narrative has been strongly connected to and supervised by an elite, ministry-led, nationalscale project that seeks to model Korea's development experience. In this regard, 
Korea's development cooperation fits the mold of other emerging donors to the extent that it is strongly influenced by elite political leadership. At the same time, this elite project has also been contested from without and within. There has been increasing participation in recent years from other state institutes, agencies and civil society organizations that seek to share other aspects of its developmental history and, for some actors, to better accord its aid policies towards more democratic norms and values in the wake of Korea's Candlelight Revolution.

The abuse of aid resources by President Park was one of the many sources of that democratic event (Kim, 2019), and, by extension helps to raise some important practical questions about the content of Korea's development narratives themselves surrounding the question of who they should benefit. Should Korea's narrative of rapid development, urban or otherwise, be presented in such a way as to provide technical solutions, or are there other, more practical, normative and democratic lessons to be gleaned from it? To what degree should its lessons be confined to advice for experts, and to what degree can it provide lessons that help to shape the formation of collective wills and democratic desires? These are questions that the current Moon administration is perhaps wrestling with as it seeks to endorse a "people-centered" ODA. It may also be one reason why an urban narrative has lately come to prominently frame Korea's development cooperation efforts more so. Perhaps a positive, urban vision of development cooperation has the potential to tell a different story about both the future and the past than previous celebratory narratives. It may be that optimistic narratives such as the creation of smart and sustainable cities contrast sharply with both the developmentalist and nationalist narratives of, and perceived corporate collusion with, past administrations. The urban narrative is also sufficiently broad to be strategically ambiguous when it comes to both the instrumental and normative dimensions of aid and cooperation. Finally, it is also one that resonates with broader focus among international organizations in promoting urban level experiments as a means of fulfilling the Sustainable Development Goals (UNRISD, 2018).

Rather than exploring the still emerging content of this new urban turn in Korea's development cooperation in detail, in this chapter we seek to explore some of the insights that contemporary human geographical research on East Asian development and urbanization might provide for understanding its associated knowledge sharing efforts.

We note that while this recent effort at urban knowledge sharing has the potential for a more reciprocal understanding of East Asian urban development, the self-referential model-building of Korea's knowledge sharing initiatives to date risk replicating the national state-centrism that has so often animated the academic literature and other celebratory narratives of East Asia's rapid economic development (cf. Meulbroek and Akhter, 2019). The story of developmental "success" that is often communicated in these narratives is one, we argue, that risks ignoring the agency of multiple geographical actors in the assembling of Korea's urban development and replicating a primarily productivist narrative of urban development that equates it with physical infrastructure investment and economic growth: for example, along the lines of narratives such as "Korea's 
modernization efforts were made possible with the construction of multi-purpose dams" (Choi, 2010). As an alternative to the methodological nationalism and technocratic orientation of much of this literature, we argue that there are potential lessons for knowledge sharing efforts to be drawn from what has recently been described as the geopolitical economy (GPE) approach. This is an approach that has emphasized the importance of a multi-scalar analysis of the forces that constitute urban space-its key actors, spatial forms, and spatial practices-and that is particularly useful, we believe, for addressing some of the normative and practical questions surrounding knowledge sharing initiatives by Asian emerging donors discussed above.

In what follows, we show how the GPE literature has the potential to make three signal contributions to knowledge sharing efforts. The first is that a GPE approach is well suited for investigating the wider spatial context of Korea's own urbanization and can be used to trouble the spatial confinement of questions surrounding the Korean urban to national boundaries of Korean territory. To this end, we review recent literature that has discussed the formation of capacities associated with Korea's "developmental state" and its material effects in urban space in their transnational context. Second, GPE can be used to scrutinize the form and meaning of the urban within East Asian developmental experiences and, by extension, can help to reveal the importance of spatial forms such as special economic zones and other distinct units of planning or "spaces of exception" to both East and Southeast Asian urbanization and planning. These units trouble conventional understandings of the urban based on an idealized understanding of city-ness (Brenner, 2017). Third, the multi-scalar, multi-actor framework embraced by GPE scholars can help to show how Korean firms and other actors have themselves become prominent actors in the urban process at home and abroad. Attention to this broader transnational context can not only moderate the state-centric narrative of past knowledge sharing efforts, but also has the potential for more transnational dialogue about the forces shaping East and Southeast Asian urban development. It can also help to cast attention on the efforts of democratic actors at multiple scales to posit a more egalitarian and sustainable vision of the urban. In sum, a GPE approach can complement the sharing of Korea's urban experience by helping it to extend beyond the merely technical or regulatory domain of expert advice in order to better address the normative concerns and social standpoints of a variety of other actors that have been affected by the broader urban processes and transnational relations that Korean urbanism has been embedded within.

\section{Methodological nationalism and narratives of urban development}

As Korea's development cooperation knowledge sharing initiatives have grown over the last 15 years, along with other Asian emerging donors-and particularly since the inauguration of the KSP's “Modularization of the Korean Development Experience" initiative in 2011 -there has been an emerging literature that has 
sought to critique the set of policy narratives that Korea and other donors have produced. Much of this literature has focused on a critique of the culturalist, state-centric and methodologically nationalist representations of development that has shaped these initiatives (Doucette and Müller, 2016; Kim and Garland, 2019; Watanabe, 2018; Schwak, 2018). In this manner, this emerging work has been indebted to an older critique of the methodological nationalism present in the wider literature on East Asian development in general and the theory of the developmental state in particular, a theory for which Korea has often represented a paragon case. By way of review, within the social sciences the rapid development of the Korean economy during the Cold War has been dominated by the perspective of the developmental state: a perspective associated with the neo-Weberian effort to "bring the state back in" to the social sciences in the late 1970s and early 1980s. This perspective has largely been occupied with documenting the sources of a modern, "rational", goal-oriented bureaucracy that could make use of its planning expertise to engineer a high-growth economy (Woo, 1991), or, in certain revisions of the theory, the state's strategic relations with key businesses and societal partners (Evans, 1995). In other words, this literature tended to largely understand rapid economic development as an effect of a strong and autonomous state and its elite partners. This is a view that ran counter to mainstream neoliberal prescriptions that attributed the East Asian region's rapid development to the liberalization of trade and flexible exchange rate policies (see, for instance, Krueger, 1987: 42-44; Bhagwati and Krueger, 1973).

The policy narratives of Asian emerging donors are seen as, in many ways, as deriving from similar value-based and state-centric narrative as the theory of the developmental state. As Kim and Kim (2014) describe, the legacy of developmental state theorizing has shaped the attractiveness of Korea's development assistance itself, and figures into the very design of its knowledge sharing initiatives and mode of cooperation (Kim and Kim, 2014). Exporting Korea's history as a successful developmental state is seen as way to instill in recipient countries the confidence to take ownership of their developmental strategy, and, to some extent, Korea's development cooperation policies have helped to share the design of institutions associated with its rapid development (e.g. the economic planning board, practices of long range planning, and, more recently, its state-funded science, technology and national territorial planning institutes). However, as Doucette and Müller (2016) argue, the actual narratives that are shared by the KSP and cognate programs often transform the narrative of the developmental state from a story of strong state intervention into a more market-friendly narrative in which the state merely imputed into the population the proper "spirit" of development, and carried out small-scale technical interventions. In this way, these narratives depart from the polemical content of the state versus market debates that shaped the theory of the developmental state. This is perhaps a strategic move, moreover, for Korea's ODA policies seek to both share experience and extend overseas business activities. Furthermore, as Jessop (2005) notes, these policy versions tend to lack an analysis of their underlying conceptual frameworks, a problem that is accentuated when policy advisors "screen out" the ambiguities and complexities 
of the original academic studies, and instead create a mythology of the state's role in development that is used to "justify and guide specific economic and political strategies" (Jessop, 2005: 23-24). The consequence, Jessop argues, is a policy celebration that can easily exaggerate claims about developmental "success" and sacrifice theoretical and empirical rigor (ibid.).

It is in part because of the limits of both developmental state theory and its more recent policy versions, that scholars from geography and beyond have continued to criticize and revise its "state-centric" approach. This state-centrism was partially due to the state vs. market polemics that the debate on East Asian development was embedded within at the time, and which tended to idealize both the state and the market as the secret to economic growth. As others have pointed out, however, the consequence of this narrow, polemical focus-one that was territorially "trapped" (Agnew and Corbridge, 1995; Hwang, 2016) in its fixation on the national scale-was the neglect of many of the recursive, multi-scalar social relations that shaped Korea's economic development due to its geopolitical and transnational economic context and that did not easily fit into its narrative of state autonomy. These relations shaped not only the accumulation of investment capital by Korean capitalists, but also the development of technical expertise, and the integration into global value chains and production networks (though Cummings' 1984 focus on product cycles provides an exception), and even the production of urban space. This is not to say that developmental state theorists simply neglected the international scale, but, rather, that they framed the context of East Asian development in terms of whether or not the autonomy of the state could be demonstrated over a particular actor, commodity or resource circulating in the wider world economy. In other words, the international, transnational, regional and other scales were regarded as a set of forces that the national state was either constrained or enabled by. By only conceptualizing the institutions that shape an economic model as primarily "national" - as has often been done by both the social scientific literature and the Korean government's modularization program-these wider relations are obscured.

The practical limitation of this approach is thus its analytic emphasis on statehood or methodological nationalism as the primary driver of economic growth. As others have pointed out, the analytical standpoint that has traditionally shaped methodological nationalism is one that prioritizes protective industrialization and carries with it strong assumptions that the nation state and modern society are "conceptually as well as historically indistinguishable" (Chernilo, 2006: 99). In other words, the emphasis is on the state's ability to continue a sustained strategy of economic nationalism with limited attention to the global nature of capitalist development. As a consequence, the nation state is prioritized as an isolated unit for development analysis and policy prescriptions. Questions of development are framed within the purview of the calculative rationality of elite bureaucrats: a viewpoint with a productivist bias that ignores the role of the public in setting a broader agenda for development. Such a view also prevents consideration of how national policies are conceived and executed within a global frame of reference with the result that nation states are theorized in abstraction 


\section{Jamie Doucette and Farwa Sial}

from the dynamics of global capitalism. For example, a linear emphasis on "outward-oriented" growth polices and the urban infrastructure required to facilitate them fails to account how global demand is not "external" to domestic industrial policy but a definitive aspect of how sector growth is prioritized (see Gore, 1996) and how firms, state capacities and urban spaces are shaped. In other words, the bifurcation of growth factors into "external" and "internal" with an undue emphasis on "internal" policy creates a narrative of development in which the gains of industrialization are not reflective of the conditions of global demand but projected as something which a nation state can control and engineer. The nation state as a singular artifact of economic growth thus takes attention away from the totality of how global capitalism leads to patterns of uneven accumulation in which some countries form the core and others are part of spectrum of peripheries.

The diverse prescriptions of KSP policy documents, although tailored to suit the structure of different countries, often reinforce a methodological nationalist view of economic growth, missing the geopolitical dynamics of growth. An example is the the 2014 KSP report on "Policy Agenda for Industrial Development in Cambodia" that analyses the role of FDI in Korean history to draw out FDI policy lessons for Cambodia. The analysis and policy lessons in this report omit the Cold War dynamics which allowed Korean capital to benefit from Vietnam War procurement (see Glassman and Choi, 2014) and ease their internationalization in East Asia and the Middle East in the 1990s through US support. This inability to contextualize geopolitics ultimately reinforces a Rostowian endorsement of modernization theory in which partner countries are presented with a takeoff version of Korean development that makes it a case of success or failure based on the national state. The problematic assumptions of this view emanate from a stagist view of economic growth largely divorced from its geopolitical and social contexts and little attention to the uneven nature of capitalist development as it spreads out across different geographies.

Another element of KSP which needs attention is an understanding of the domestic political economy dynamics. An example is the 2016/2017 KSP with Ethiopia, which focuses on establishing resilient cities and regional industrial development. While it provides detailed research that identifies the structural bottlenecks to sustainable urbanization, the KSP's prescription that Ethiopia pursue a land registration system, misses the nuances of domestic political economy dynamics that form the basis of obstacles to legal ownership of land. The issue of distribution of land ownership between the state and various stakeholders is ultimately an issue of power and structural exclusion to maintain a certain status quo. In Ethiopia particularly, restrictions on land transfer were historically imposed by the state and resulted in disadvantage to smallholder farmers. The country's current strategy of land liberalization designed to facilitate foreign ownership extends the previous dynamics of state power through state-controlled leasing (see Lavers, 2012). A technocratic approach to asset distribution in this context misses the political settlements which continue to impact land ownership and the drivers of land leasing in Ethiopia. 


\section{Contextualizing the urban}

More recent work within geography and the social sciences has tried to correct for the tendency towards methodological nationalism in accounts of East Asian growth. They have done so for a variety of reasons, including the examination of how the state and GVCs/GPNs have interacted across scales within East Asia and on the Korean peninsula (Yeung, 2016; Horner, 2017; Kaplinsky and Morris, 2016), the analysis of the geopolitical context of Cold War developmentalism (Glassman, 2018; Hsu, Gimm and Glassman, 2018) in the region, and, generally, for a better understanding of the social and political challenges that have arisen from Cold War industrialization. In this literature, the state, transnational class and foreign policy actors, migrants and even the firm itself are seen as key agents that have helped internationalize state and society by helping to secure international contracts, import technology and localize value chains. While the role of the urban has remained latent in much of this work until more recently, scholars associated with this perspective have long regarded it as a key site where internationalization processes take shape (see Park, 2005). So much has been pointed out by scholars associated with the geopolitical economy approach described above (see Doucette and Park, 2018), for they have noted how the urban process has been an integral part of East Asian development experiences. This can be considered both in the manner in which key firms gained expertise and capital through participation in Cold War procurement (e.g. port dredging and highway building as well as manufacturing) (Glassman, 2018), but also in the manner in which urban construction served as a vehicle for accumulation, class formation and the cementing of political alliances (Joo, 2018; Sonn and Shin, 2018), or as a site of dissent and resistance (Jo, 2010). Moreover, it is not only the city as such that has been the urban form that is key to this process, but rather various spaces of exception-such as special industrial complexes, export processing zonesthat appear integral this process of integration (Doucette and Lee, 2015).

GPE's multi-scalar emphasis has been mirrored by institutional actors such as UNCTAD, which has sponsored research into the rapid expansion of GVCs and argues that a revised view of developmental states may be key to integrating them. The high import content requirements, infrastructure and training they involve in developing countries requires active industrial policy and infrastructural and social support (Kozul-Wright and Fortunado, 2015: 468; Milberg and Winkler, 2013; see also Salazar-Xirinachs, Nubler and Kozul-Wright, 2014; UNCTAD, 2015). Given this renewed focus on East Asian growth, the role of the state and participation in GVCs, ensuring attention to the geopolitical economic dimensions of Korean urbanization and developmentalism seems particularly important. It has the potential to contribute to this literature by focusing not only on how multi-scalar networks such as GVCs have been localized on the Korean peninsula through the production of urban space. It can be also be used to temper methodologically nationalist claims that all that is required for the localization of GPNs and GVCs is strong national-level state policy, as well as normative claims that GVC integration is necessarily a good thing. A strong 


\section{Jamie Doucette and Farwa Sial}

state might well strengthen the competitiveness of the domestic value chain and provide some of the "horizontal" resources needed for them, however, it cannot control against lead firms' dominance in the GPN and associated structural obstacles to upgrading. Of course, if our critique of methodological nationalism is that it valorizes the standpoint of state planners and what Gillian Hart calls capital "D" development (Hart, 2010), the response of geopolitical economy should not be to simply shore up this productivist focus by removing it from its nationalist moorings with the help of GVC frameworks, but, rather, to question its framing of (urban) development to begin with. In other words, the object of a critical approach to Korea's urban development is not simply to provide advice on what makes its development "successful", but, rather, to understand urbanization as a process from a variety of social standpoints. Moreover, the latter can be used to provide a more critical evaluation of that experience of development and thus help to transform it in a more substantive and democratic manner.

There is another implication of the contextualizing perspective. And this is that if we embrace a multi-actor and multi-scalar perspective, the location of the "Korean" urban experience should not simply be in Korean national space itself, but be extended transnationally. The production of urban spaces for development should not be regarded simply as an exercise in national state planning but should be seen in light of its colonial and post-colonial roots. Japanese capital has already located considerable commodity chains, especially in agriculture, within Korea during the colonial era. Military procurement during the Korean and Vietnam wars also further integrated NE Asian value chains and production networks. As Rosen (2002) describes, the geopolitical context of the textile and apparel industries in particular is intricately connected to this economic history to the extent that the effects of the post-WWII aid and investment nexus are difficult to disentangle from national policies and the agency of private firms and other actors. The Korean "urban" and its spatial forms-from industrial complexes, apartment blocs and special economic zones-has also extended with the reach of firms' value chains into East and Southeast Asia and beyond. This activity involves considerable investment in urban infrastructures across the region, an effort that has been complemented by Korea's growing role in development cooperation. A focus on the multi-scalar interplay of these actors not only questions how we locate Korean urbanism, it also can help to raise normative and political arguments about the wider production of urban space and whom it serves.

This transnational history has often been elided in the scholarship on the geography and planning of urban spaces such as special economic zones. For instance, Masan Free Economic Zone and its neighboring Changwon Industrial District have described it as a strong case of state-led industrial policy (Markusen and Park, 1999; Lee, 1999). However, scholars such as Park and Choi (2014) have shown how the zone was strongly influenced by the initiative of both local officials and, more importantly, Korean-Japanese businessman with strong connections to the Masan area due to Japan's colonial rule in Korea and Masan's pre-colonial history as an open port used by Japan. As Yuan and Eden (1992) observed, MAFEZ outperformed the failed Iri (Iksan) Free Export Zone (also based on Kaoishung). 
The latter was opened in 1973 but terminated by the late 1980s, in part, perhaps, because it lacked these sort of transnational business networks that made the crucial difference (for a detailed examination, see Choi and Kim, 1991). In short, there is a tendency in the literature to associate such zones either with the prerogatives of state managers, or, conversely, with deregulated free markets and foreign investment (see Cartier, 2018 for an excellent critique of this trend). But, in practice, either is rarely the case. It is rather the case that there are always some sort of interests, specific networks of actors and geometry of power relations that shape how urban spaces such as "zones" will unfold. Moreover, as Song (2019) points out, the spatial-temporal context of Korea's own zonal development policies are often obscured when rendered into policy prescriptions in the KSP, for instance. Zones like MAFEZ appear as "out of the box" solutions that can be easily replicated when in reality they are highly contextual in time and space (cf. Martin and Geglia, 2019).

Another challenge for knowledge sharing efforts about Korean urbanism is that since the 1980s, Korean capital has itself become active in extending urbanization through its transnational production and construction. As strategic zoning and other spaces of exception helped shape the rise of many of Korea's dominant firms and conglomerates and their integration into global value chains, these urban spaces have also become instrumental for their capital accumulation and investment as they have expanded beyond Korean territory, raising the question of where and how exactly we might locate Korean urbanism and how we understand normative issues attached to it. For instance, the Youngone Corporation, a massive first tier supplier (Azmeh and Nadvi, 2014) to global brands such as The North Face, set up the privately-run Korea Export Processing Zone (KEPZ) near Chittagong, Bangladesh, in 1996, a zone that has often received negative attention due to regulations banning labor activism and reports of repressive labor relations in the zone (Hankyoreh, 2014). Other large Korean lead firms and first tier suppliers have been push factors for industrial zone and complex development across Southeast Asia. This investment has often been accompanied strategically by ODA and OOF (other official flows) that have helped Korean firms cement their foothold in emerging and strategic markets. As mentioned above, Korea's knowledge sharing projects share narratives of urban development and regulation (KDI, 2016). Meanwhile, Korea's infrastructure-led development cooperation projects are also tailored, in many respects, toward building urban infrastructures. Korea markets its competencies in building combined infrastructures needed for SEZs: industrial districts, power plants, port dredging and construction, smart cities and apartment complexes. These competencies form a development "package" based on replicating the infrastructure of both the rise of Korean lead firms and the integration of Korean manufacturing into GVCs. These investments have not been without controversy as in the case of labor protests in Korean factories and other industrial complexes in Cambodia, and attention in the media as to whether or not they were exacerbated by intervention from Korean business and embassy officials (AMRC, 2014). 


\section{Jamie Doucette and Farwa Sial}

\section{Discussion: urban-industrial knowledge sharing for whom?}

While our discussion of Korea's urban knowledge sharing and the insights of the GPE critique has been brief, we hope that it can help raise a few salient points. As discussed above, the first is that we might trouble the spatial confinement of questions surrounding the Korean urban development experience to actors and processes primarily located in the national boundaries of Korean territory. The sources that have shaped Korea's urban space, and even their location (in the case of SEZs, etc.) are transnational and multi-scalar. Second, such a broader focus is useful in that it can be used to reveal the importance of spatial forms such as special economic zones and other distinct units of planning or "spaces of exception" to both Korean and East and Southeast Asian urbanization and planning. The developmentalist urban is not simply the site of the city, per se, but involves the production of other spaces that have been integral to economic growth, the conceptualization of which should be understood not only in productivist but also normative terms that consider the viewpoints of actors affected by such forms of urban planning. Third, it can help to show how Korean firms have themselves become prominent actors in the urban process at home and abroad. We feel that the GPE approach, by providing a more multi-scalar sensitivity, offers a chance to scrutinize methodological nationalist frameworks. But it also has further political implications that we might discuss here. For it might provide an opportunity to contest the political prescriptions that often accompany methodologically nationalist readings of development.

For instance, as discussed above, a distinct characteristic of the Korean ODA model is how it has embedded its own historical development experience as a potentially replicable lesson for developing countries (see Kim, Kim and Lee, 2014). However, in doing so, Korea's historical experience is often presented as a neutral ground in which policy was successful owing to a simplistic combination of resource allocative measures. This approach has multiple consequences: it eliminates contestation between different aspects of society in Korea's turbulent history, in effect rendering Korea's development experiences as "technical" and ahistoric policy measures to be adapted by developing countries (Doucette and Müller, 2016). And yet, it is perhaps that history of contestation and change that should be shared, for it opens up the very meaning of the urban to diverse social actors and allows for communication between them. Additionally, it detaches policy making in developing countries from their distinct social and geopolitical contexts. The viability of replicability and achieving a certain promised standard of socioeconomic growth in developing countries thus becomes an ideal-type which is distinct from their economic realities. Finally, the urban spaces that were crucial for such growth policies to work in their highly specific geopolitical context to begin with are often regarded in a technical or infrastructural manner. As such, the role of the urban as a site of labor control, the familial, ethnic and expert networks that shape and connect urban spaces and the transnational flows and processes in which urban spaces are connected remain peripheral to technical advice. This elision makes it difficult to render normative judgment on the type 
of spatial policies and planning practices that help to make and govern such urban spaces.

Inevitably the question of who urban knowledge is created for and shared with is thus raised here. For it seems that a more ecumenical and pluralistic understanding of East Asian urban development experiences would also involve greater interrogation of their effects on the public sphere, and, by extension, inclusion and participation of those groups that have tried to modify and change the nature of urban space: for instance, the sharing of knowledge by those affected by displacement, gentrification and other forms of urban inequality could provide the basis for more progressive forms of knowledge sharing and planning reform. Sharing both the shadows and the light of the Korean urban experience in this manner could also better accord ODA policies with democratic demands articulated in recent events such as the Candlelight Revolution. Moreover, such a vision has the potential to undermine methodologically nationalist arguments and productivist prescriptions. As difficult as that conversation might be to some, it can also generate a more critical understanding of the urban development experiences in a manner that helps to better serve democratic desire for a better and more sustainable urban future.

\section{References}

Agnew, J. and S. Corbridge (1995). Mastering Space: Hegemony, Territory and International Political Economy. New York: Routledge.

AMRC (2014). A Week that Shook Cambodia. The Hope, Anger and Despair of Cambodian Workers after the General Strike and Violent Crackdown (December 2013-January 2014). Hong Kong: AMRC.

Azmeh, S. and K. Nadvi (2014). "Asian Firms and the Restructuring of Global Value Chains," International Business Review 23(4), pp. 708-717.

Bhagwati, J. N. and A. O. Krueger (1973). "Exchange Control, Liberalization, and Economic Development," The American Economic Review 63(2), pp. 419-427.

Brenner, N. (2017). Critique of Urbanization: Selected Essays 156, Gütersloh, Bauverlag, Basel: Birkhäuser.

Cartier, C. (2018). "Zone Analog: The State-Market Problematic and Territorial Economies in China," Critical Sociology 44(3), pp. 455-470.

Chernilo, D. (2006). "Methodological Nationalism and its Critique," in G. Delanty and K. Kumar (eds), The Sage Handbook of Nations and Nationalism. London: Sage, p. 129.

Choi, Y. (2010). "Korea Exporting Knowhow on Dam Construction," Korea Times. Available at: www.koreatimes.co.kr/www/news/biz/2016/01/291_66552.html [Accessed February 20, 2020].

Choi, J. C. and W. B. Kim (1991). "The Influence of Foreign Investment on Local Economic Development: Iri Free Trade Zone of Korea," Southeast Asian Journal of Social Science 19(1/2), pp. 139-153.

Doucette, J. (2020). "Anxieties of an Emerging Donor: The Korean Development Experience and the Politics of International Development Cooperation," Environment and Planning C: Politics and Space 38(4), pp. 656-673. 


\section{Jamie Doucette and Farwa Sial}

Doucette, J. and B. G. Park (2018). "Urban Developmentalism in East Asia: Geopolitical Economies, Spaces of Exception, and Networks of Expertise," Critical Sociology 44(3), pp. 395-403.

Doucette, J. and A. R. Müller (2016). "Exporting the Saemaul Spirit: South Korea's Knowledge Sharing Program and the 'Rendering Technical' of Korean Development," Geoforum 75, October 2016, pp. 29-39. Available at: https://doi.org/10.1016/ j.geoforum.2016.06.018 [Accessed February 20, 2020].

Doucette, J. and S. O. Lee (2015). "Experimental Territoriality: Assembling the Kaesong Industrial Complex in North Korea," Political Geography 47, pp. 53-63.

Evans, P. B. (1995). Embedded Autonomy: States and Industrial Transformation. Princeton, NJ: Princeton University Press.

Glassman, J. and Y. J. Choi (2014). "The Chaebol and the US Military-Industrial Complex: Cold War Geopolitical Economy and South Korean Industrialization," Environment and Planning A: Economy and Space 46(5), pp. 1160-1180. Available at: https://doi. org/10.1068/al30025p [Accessed February 20, 2020].

Glassman, J. (2018). Drums of War, Drums of Development: The Formation of a Pacific Ruling Class and Industrial Transformation in East and Southeast Asia, 1945-1980. Leiden: Brill.

Gore, C. (1996). "Methodological Nationalism and the Misunderstanding of East Asian Industrialisation," The European Journal of Development Research 8, pp. 77-122.

Han, J. J. H. (2015). "Our Past, Your Future: Evangelical Missionaries and the Script of Prosperity," in A. Roy and Shaw, E. (eds), Territories of Poverty: Rethinking North and South. University of Georgia Press, Athens, pp. 176-194.

Hankyoreh (2014). "Interactive Feature: How a Pay Raise Killed Workers: the Story of a North Face Manufacturer in Bangladesh.” Available at: http://hani.co.kr/interactive/ bangla/english.html [Accessed February 20, 2020].

Hart, G. (2010). "D/developments After the Meltdown," Antipode 41(S1), pp. 117-141. doi:10.1111/ j.1467-8330.2009.00719.x

Horner, R. (2017). "Beyond Facilitator? State Roles in Global Value Chains and Global Production Networks," Geography Compass 11(2), pp. el2307.

Hsu, J. Y., D. W. Gimm and J. Glassman (2018). "A Tale of Two Industrial Zones: A Geopolitical Economy of Differential Development in Ulsan, South Korea, and Kaohsiung, Taiwan," Environment and Planning A: Economy and Space 50(2), pp. $457-473$.

Hwang, J. T. (2016). "Escaping the Territorially Trapped East Asian Developmental State Thesis," The Professional Geographer 68(4), pp. 554-560.

Jessop, B. (2005). "Critical Realism and the Strategic-Relational Approach," New Formations: A Journal of Culture, Theory and Politics 56, pp. 40-53.

Jo, J. H. (2010). Kongdong Doshi [The Common City]. Kalmuri, Seoul.

Joo, Y. M. (2018). Megacity Seoul: Urbanization and the Development of Modern South Korea. New York: Routledge.

Kaplinsky, R. and M. Morris (2016). "Thinning and Thickening: Productive Sector Policies in the Era of Global Value Chains," The European Journal of Development Research 28(4), pp. 625-645.

Kim, E. M., H. J. Kim and J. E. Lee (2014). "Aid Effectiveness and Fragmentation: Changes in Global Aid Architecture and South Korea as an Emerging Donor," in E. M. Kim (eds), The South Korean Development Experience Beyond Aid. Basingstoke: Palgrave MacMillan. 
Kim, E. and H. Kim (2014). "From Development to Development Cooperation: Foreign Aid, Country Ownership, and the Developmental State in South Korea," in E. Kim and H. Kim (eds), The South Korean Development Experience Beyond Aid. London: Palgrave, pp. 7-25.

Kim, J. and J. Garland (2019). "Development Cooperation and Post-Colonial Critique: An Investigation into the South Korean Model," Third World Quarterly 40(7), pp. 1-19.

Kim, S. (2019). "The Misadventure of Korea Aid: Developmental Soft Power and the Troubling Motives of an Emerging Donor," Third World Quarterly 40(11), pp. 1-25.

Korea Development Institute (2016). Special Economic Zones: What Can Developing Countries Learn from the Korean Experience? Sejong: Knowledge Sharing Program. Ministry of Strategy and Finance.

Kozul-Wright, R. and P. Fortunato (2015). "Sustaining Industrial Development in the South,” Development 58(4), pp. 463-472.

Krueger, A. O. (1987). The Importance of Economic Policy in Development: Contrasts between Korea and Turkey. NBER Working Paper Series No. 2195. Cambridge, MA: National Bureau of Economic Research.

KSP Policy Consultation Report (2014). "Policy Agenda for Industrial Development in Cambodia." Available at: www.ksp.go.kr/english/pageView/info-eng/95?listCount $=10 \&$ page $=2 \& \operatorname{srchText}=\& \mathrm{kspCd}=048 \& \mathrm{kspCd}=047 \& \mathrm{kspCd}=046 \& \mathrm{kspCd}=045 \& \mathrm{ks}$ pCd=049 [Accessed February 20, 2020].

Lavers, T. (2012). "Patterns of Agrarian Transformation in Ethiopia: State-Mediated Commercialisation and the 'Land Grab'," Journal of Peasant Studies 39(3-4), pp. 795-822.

Lee Y. S. (1999). "The Masan Free Export Zone: Conflict and Attrition,” in A. R. Markusen, Y. S. Lee and S. DiGiovanna (eds), Second Tier Cities: Rapid Growth Beyond the Metropolis, 3, Minneapolis: University of Minnesota Press, pp. 183-198.

Markusen A. and S. Park (1999). "Changwon: A State-Sponsored Industrial District," in A. R. Markusen, Y. S. Lee and S. DiGiovanna, eds (1999). Second Tier Cities: Rapid Growth Beyond the Metropolis, 3, Minneapolis: University of Minnesota Press, pp. $163-182$.

Martin, B. and B. Geglia (2019). "Korean Tigers in Honduras: Urban Economic Zones as Spatial Ideology in International Policy Transfer Networks," Political Geography 74.

Mawdsley, D. E. (2012). From Recipients to Donors: Emerging Powers and the Changing Development Landscape. London: Zed Books Ltd.

Mawdsley, E., S. M. Kim and D. Marcondes (2017). "Political Leadership and 'Non-Traditional' Development Cooperation," Third World Quarterly 38(10), pp. 2171-2186.

Meulbroek, C. and M. Akhter (2019). "The Prose of Passive Revolution: Mobile Experts, Economic Planning and the Developmental State in Singapore," Environment and Planning A: Economy and Space, pp. 1242-1263.

Merk, J. (2014). "The Rise of Tier 1 Firms in the Global Garment Industry: Challenges for Labour Rights Advocates," Oxford Development Studies 42(2), pp. 259-277.

Milberg, W. and W. Deborah (2013). Outsourcing Economics: Global Value Chains in Capitalist Development. New York: Cambridge University Press.

Ministry of Land, Infrastructure and Transport (2019). Plan to Revitalize Overseas Smart City Expansion [in Korean]. Available at: https://bit.ly/2Fvacj3 [Accessed August 2020].

Park, B. G. (2005). "Spatially Selective Liberalization and Graduated Sovereignty: Politics of Neo-Liberalism and 'Special Economic Zones' in South Korea," Political Geography 24(7), pp. 850-873. 


\section{Jamie Doucette and Farwa Sial}

Park, B. G. and Y. J. Choi (2014). "Relations between the State and the Local in the Construction of Masan Export Processing Zone," Journal of the Korean Geographical Society 49(2), pp. 113-138. (In Korean).

Rosen, E. I. (2002). Making Sweatshops: The Globalization of the US Apparel Industry. Berkeley: University of California Press.

Salazar-Xirinachs, J. M., I. Nubler and R. Kozul-Wright (2014). Transforming Economies: Making Industrial Policy Work for Growth, Jobs and Development. Geneva: International Labour Organization.

Schober, E. (2018). "Working (Wo)Man's Suicide: Transnational Relocations of CapitalRepercussions for Labour in South Korea and the Philippines," Journal of the Royal Anthropological Institute 24(S1), pp. 134-147.

Schwak, J. (2018). "Dangerous Liaisons? State-Chaebol Cooperation and the Global Privatisation of Development," Journal of Contemporary Asia, doi: 10.1080/ 00472336.2018.1501806

Sial, F. and J. Doucette (2020). "Inclusive Partners? Internationalising South Korea's Chaebol through Corporate Social Responsibility-linked Development Cooperation," Third World Quarterly. doi 10.1080/01436597.2020.1782185

Song, E. (2019). "Transplanting Developmentalism from East Asian States to Developing Countries through ODA; A Case Study of KDI," Presentation at EARCAG-GPE Workshop, Osaka, November 2019.

Sonn, J. W. and H. B. Shin (2018). "Contextualizing Accumulation by Dispossession: The State and High-Rise Apartment Clusters in Gangnam, Seoul," Annals of the American Association of Geographers 110(3), pp. 864-881.

Stallings, B. and E. M. Kim (2017). Promoting Development: The Political Economy of East Asian Foreign Aid. Singapore: Palgrave Macmillan.

UNCTAD (2015). Global Value Chains and South-South Trade: Economic Cooperation and Integration among Developing Countries. Geneva: United Nations.

UNRISD (2018). Social and Solidarity Economy for the Sustainable Development Goals: Spotlight on the Social Economy in Seoul. Geneva: UNRISD.

Watanabe, C. (2018). "Instrumental Culturalism: The Work of Comparisons Across Japan, 'the West' and Myanmar," TRaNS: Trans-Regional and National Studies of Southeast Asia 6(1), pp. 27-45.

Williams, J., C. Robinson and S. Bouzarovski (2019). "China's Belt and Road Initiative and the Emerging Geographies of Global Urbanisation," The Geographical Journal. doi.org/10.1111/geoj.12332

Woo, J. (1991). Race to the Swift: State and Finance in Korean Industrialization. New York: Columbia University Press.

Yeung, H. (2016). Strategic Coupling: East Asian Industrial Transformation in the New Global Economy. Ithaca, NY: Cornell University Press.

Yuan, J. D. and L. Eden (1992). "Export Processing Zones in Asia: A Comparative Study," Asian Survey 32(11), pp. 1026-1045. 


\title{
7 A multitude of models \\ Transferring knowledge of the Korean development experience
}

\author{
Cuz Potter and Jinhee Park
}

\section{The singular model}

Over the last decade, as part of its Knowledge Sharing Program (KSP), South Korea has prepared a series of documents that strive to consolidate Korea's development experience into a "Korean model". To date, well over 150 Knowledge Sharing Papers addressing a wide range of fields have been produced. These government-sanctioned reports seek to cohesively and comprehensively identify the critical components of the country's unique experience and "modularize" them for easy transfer to developing nations that desire to learn from Korea's experience. This suite of systematized case studies are offered freely for other countries' policy makers to reference in their own policy formulation and for Korean practitioners to draw on when providing assistance. While this effort represents a positive contribution to the development community as a whole, this chapter argues that Korea's KSP would be better served by producing a multitude of models in partnership with developing country stakeholders.

The literary theorist Bakhtin argued that any effort to centralize and unify a narrative simultaneously serves to fragment and disunify possible and existing narratives. That is, consolidating a narrative ultimately adds an additional narrative to the multitude of existing narratives told by other actors. Following this notion, the development of a singular Korean model only expands the number of possible models describing Korea's development experience. By presenting a governmentsanctioned, "sanitized" version of events that highlights the positive aspects of Korea's experience (Howe, 2015), the consolidated model simultaneously calls forth other narratives. Some of these highlight more negative aspects of Korea's experience, like labor repression, eviction and environmental damage, some of which are identified by other chapters in this volume. Others illuminate more benign aspects of the development experience that may be overlooked by Korean scholars and officials but could be of immense use to actors in developing countries. In short, striving for a singular model necessarily obscures much of the rich experience and knowledge Korea has accumulated.

Rather than bemoan the heteroglossia of narratives, the multitude of models, this chapter embraces and encourages it. It does so first by presenting a fragile case of the Korean model: the transfer of large-scale residential development 
construction to developing countries, Vietnam in particular. It is first shown that while the case could be harmonized with elements contained in the Korean model, this narrative is a fragile one that holds together only by abusing the unity of the model. The chapter then shows that any model has to be adapted to other contexts and that the process of adaptation inherently generates new narratives. Finally, the chapter concludes by claiming that the KSP process should produce a multitude of models specific to the needs of each partner.

\section{Limited narratives}

Over the last 25 years, Korean firms have built a number of large-scale residential projects in Vietnam, especially Hanoi. Beginning in 1996, Korean projects in Hanoi have ranged from the new towns of Splendora and Starlake built by POSCO and Daewoo, respectively, to the Hillstate apartment complex built by Hyundai in the Ha Dong neighborhood, to Landmark 72's soaring residential towers built by Keangnam. Though these projects all began prior to the KSP modularization endeavor, their introduction to Vietnam could be narrated in a way consistent with the Korean model. For instance, one might suggest that against a backdrop of rapid economic growth, rapid urbanization produced a housing shortage that could not easily be addressed through existing construction practices. Moreover, more traditional housing designs were often perceived as backward and even inhibiting further economic and social progress. Therefore, both countries imported foreign technologies for producing high-rise, high-density apartment complexes and new towns.

The following sections will demonstrate, however, that the superficial similarity of this narrow narrative obscures more than it reveals. We do not make any claims that this narrative is being actively promoted by any stakeholders of whom we are aware; rather, it serves here as an example of how simple models quickly break down and become irrelevant, calling into question the efficacy of sharing a modularized depiction of the Korean experience. The next section identifies a common basis for comparing the Vietnamese experience with the Korean: attempts to introduce modernity through high-rise apartment buildings. The following two sections demonstrate how the knowledge transfer and business organization components of the Korean experience break down in application in the Vietnamese context. Then, a section on housing adaptation exposes one narrative fragment that is not part of the "Korean model" but could be. All three sections demonstrate the existence of additional narratives that complement the official narrative of a Korean model.

The following analysis draws on a variety of sources. Archival research, including KSP papers, in combination with secondary sources provides much of the historical background of Korea's development. The same sources contribute to our understanding of Korean actors' activities in Vietnam, and are complemented by interviews with Korean architects, government officials, think tank representatives and urban planners conducted during 2016 and into early 2017. Interviews during the same period in Hanoi were conducted with scholars, real estate agents and government officials. These formal interviews 
were bolstered by focus group discussions in early 2017 with tenants of both foreign and domestic apartments in Hanoi and Seoul. Further, an online, snowballsampled survey of residents of both countries conducted in late 2016 drew 83 responses from Vietnam and 99 from Seoul.

\section{Housing embodies modernity}

In Vietnam, modern, high-rise buildings serve as both symbols of modernity and vehicles for realizing that modernity, just as the early apartment buildings of the 1950s and 1960s did in Korea. The housing developments themselves physically embody modern practices and encourage - if not force-their residents to adopt those practices. This impact of technological form on behavior is notably demonstrated by Foucault (1991) in his explanation of how disciplinary mechanisms are embodied in prison design. Latour (1990) brings this argument to actor-network theory (ANT) through his example of how a European hotelier of decades past might use heavy, bulky keys to ensure that the guest leaves them at the front desk when they go outside the hotel. Latour summarizes this independent action of the key on the guest as "technology is society made durable". In the same sense, one could say that modern societal practices are also embedded in the built form, whether it be housing, light rail, bus rapid transit lanes or closed circuit TV networks. As residents interact with the physical embodiment of modern practice, they evolve into new patterns of modern living, for example, using air conditioning on humid days.

In Korea, after Chung-hee Park took power in 1961, the Korean National Housing Corporation (KNHC) commissioned and constructed Mapo Apartments, Korea's first apartment complex. There was virtually no attempt to adapt the design to Korean preferences or needs. On the contrary, there was an active effort to translate Korean practices to match the built form as a means of rejecting "backward" practices and adopting modern, Western practices, as suggested in the following excerpt from an article entitled "A discussion on apartments and the Western lifestyle: A solution to the housing shortage" in the 18 April 1963 edition of the Kyunghyang News.

Mr. Jang: We need to change our living style into that of Western. That's why we force that in Mapo Apartment ...

Mr. Hwang (Hwang Yongyeon, General manager of Housing Department at the Ministry of Construction): Should the government encourage the Western life style through the construction of apartments? That's the question we need to think about. Koreans share national characteristics of keeping their private life secret and hating unity. We need to break this down. The lifestyle of sitting on the floor entails slow movement and is inefficient because it takes time and energy to stand up when we sit on the floor. The government should institute policies for the improvement of our ethnicity ...

Park Hakjae (Architect, Hanyang University Professor): We need to do away with ondol (radiant heating) and adopt the Western style for the 
implementation of far-sighted national policies. The Western living style is also good for the development of children.

In Vietnam, too, contemporary foreign apartment designs are perceived as more modern and as embodying desirable modern lifestyles. In focus group discussions, participants consistently described foreign-designed and built apartments as more "modern" than traditional housing and domestic apartment designs, associating them with convenience, beauty and "sensible organization". In the survey, more than half of Vietnamese respondents believed that the foreign nationality of a project developer was important, and almost 80 percent stated that modern design was important. Korean respondents' figures for these two variables were significantly lower, with less than 40 percent finding the developer's nationality to be important and less than 65 percent feeling that modern design was important. The importance of modern design to Vietnamese respondents is evident in the fact that nearly two-thirds of respondents claimed that design was more important than brand, while roughly the same proportion of Korean respondents reported exactly the opposite assessment. The difference between Korea and Vietnam in these cases may to some extent be attributable to the level of economic development, but this only serves to highlight the notion that foreign designs are perceived as more modern in the early stages of development.

Similar opinions have been noted about new towns, known as "New Urban Areas" (NUAs) in Vietnam. Potter and Labbé (2020) report interviewees describing NUAs as "clean", "beautiful", "modern" and "civilized". They are seen as ushering in a new, modern Vietnam and as embodying the success of the national development project. As Harms (2016: 22) argues, citizens associate NUAs with “a nationalist vision of Vietnam's advance into modernity".

This comparison shows that many Vietnamese see the introduction of foreign housing as an essential element of modernization and development, just as Koreans did in the 1950s and after. So, to the extent that housing as a tool of modernization is a component of the Korean model (Park, Gwon and Lee, 2012: 36), then Vietnam could be said to be replicating that model. However, while the role of modern, foreign housing may be similar and can be interpreted as following the same model of development, this reading is fundamentally superficial. The following two sections will show how ostensibly similar model practices quickly break down upon closer examination.

\section{Public and private partnership}

Vietnam's large-scale residential developments could be seen as following the Korean model through the fundamental relationship between the public and private sectors. In both cases the public sector has paved the way for private sector profits. However, while Korea restricted private sector actors to domestic firms and independent contractors, Vietnam has-at least until recently-encouraged the participation of foreign firms in joint ventures with Vietnamese firms. 
The standard model for new town construction in Korea has been for the public sector, mainly through the KNHC and Korea Land Corporation or their recently merged entity, the Korea Land and Housing Corporation ( $\mathrm{LH}$ ), to manage the projects overall, while outsourcing first the site preparation and then, typically after transferring land ownership, the design and construction of large parcels to domestic private sector firms. "This is a new city development controlled by private developers" (Lee, 2012: 100).

While this broad pattern holds in Vietnam, the country's post-socialist history adds a new wrinkle. The role of the state in expropriating land for subsequent development remains, but the legacy of state-owned enterprises (SOEs) means that many of the large domestic enterprises capable of large-scale construction have been and may still be SOEs rather than private firms, as in Korea (Labbé and Musil, 2013). One major difference is the openness to foreign firms participating in the domestic real estate development market. Developers from Korea, Indonesia, Singapore and elsewhere have all acted as the main private sector developer of large-scale residential projects. There is an important caveat to their participation, however. They must enter into joint ventures with Vietnamese firms, whose in-kind investment typically consists of the land use rights.

This represents a major departure from the Korean experience. One of the core characteristics of Korea's early development was its emphasis on retaining local control of industry by relying on loans and technology licensing, rather than foreign direct investment (FDI) (Lee et al., 2011). Though the legal foundation for FDI was present from the 1960s, FDI remained restricted or prohibited in some sectors, including real estate, and only gradually expanded, mainly from the end of the 1980s (Nicolas, Thomsen and Bang, 2013). Thus, to constrict the narrative of Vietnamese development to the Korean model, one would have to draw on multiple stages of the Korean experience and selectively combine isolated elements, which certainly ignores each period's institutional cohesion and implies a new narrative.

\section{Knowledge transfer}

Building modern buildings requires modern technology. Lacking expertise in modern building construction, both Korea and Vietnam turned to foreign expertise. However, the actors seeking and providing the knowledge are different. In Korea's case, the Korean government sought out and employed foreign private sector experts. In Vietnam, foreign private sector firms collaborated through FDI with private or quasi-public Vietnamese firms, to whom they conveyed their expertise.

Initially, single floor Western models were introduced to Korea at scale through the urgency of UN housing programs to address housing shortages after the Korean War. Then, in the late 1950s, the Korean government became actively involved in introducing and encouraging Western-style housing designs and technologies. A number of government agencies, including the Industrial Bank (IB), the Ministry of Health and Social Affairs (MHSA) and the Combined 


\section{Cuz Potter and Jinhee Park}

Economic Board (CEB), contributed to promulgating apartment construction. The IB researched apartment designs throughout the decade, made favorable loans to housing cooperatives that adopted Western-style housing and reviewed construction applications, often stipulating improvements in design. At the Combined Economic Board (CEB), which was the post-Korean War vehicle for advising and coordinating economic policy with the US aid agency and facilitating the implementation of US aid (Yi and Mkandawire, 2014), Kwang-ro Lee, who was responsible for construction and maintenance, suggested in 1956 that apartment-style plans be built and modern construction technology be introduced to resolve the growing housing shortage. With the weight of the CEB behind them, these suggestions formed the basis for the construction of Korea's first apartment buildings in the following years. The government further fostered the introduction of Western-style apartments through design competitions hosted by the Ministry of Health and Social Affairs and the US International Cooperation Agency. The winners of the first competition proposed south-facing row apartments with bedrooms facing south and the living room and kitchen/ dining room located together near the entrance, the basic model of apartment housing that dominated for roughly two decades. Additionally, the KNHC, which was formally in charge of post-war reconstruction, also adopted the modern style of apartment design, building Gaemyeong Apartments in 1959. The KNHC continued to promote and build such designs during the 1960s and beyond, including the Mapo Apartments mentioned above, as inculcating Western living practices in their residents. It was only after the government took responsibility for introducing and normalizing Western-style building that the private sector actively joined in (Korean Institute of Architects, 1994).

In Vietnam, it was not the domestic government that pressed for the introduction of foreign building design and technology. Rather, to capitalize on Vietnam's growing economy, foreign firms themselves sought means for introducing large-scale residential projects. Korean firms have been particularly active in this regard and have operated independently and with organized support from the Korean government (Lee, 2014). Daewoo was one early actor. In 1997, the company convinced the Vietnamese government to allow it to develop a large site $\left(11 \mathrm{~km}^{2}\right)$ north of the central city across the Red River, an ambitious recapitulation of Seoul's 1970s expansion into Gangnam, the land on the south side of the Han River. Though this private endeavor failed due to the Asian financial crisis, in 2002 the Korean government organized a consortium of government ministries, public organizations and private sector firms to pursue construction opportunities in Vietnam. The Korean government supported this process by signing a memorandum of understanding with the Vietnamese government to encourage construction contracts (Kim, 2002). As mentioned above, the subsequent projects were pursued through joint ventures between Korean and Vietnamese firms. This private sector channel has served as the primary avenue for technology transfer in construction.

This comparison shows that despite a common strategy of importing technological skills and knowledge, there are significant challenges to the 
applicability of the Korean model to the Vietnamese experience. The Korean model involved extensive government support for introducing and encouraging the adoption of foreign building technologies. In Vietnam, the import of foreign technological know-how was at best indirectly supported by the state. Rather, foreign expertise came knocking at Vietnam's door in the form of FDI, especially from Korea. Though the Korean model would also include the strategic use of FDI, this narrative would require conflating selected institutional aspects of multiple incommensurate periods of Korea's development. As with business organization discussed above, this conflation undermines the utility of a single model, but in doing so it opens possibilities for more original, synthetic narratives of the Korean experience that may be of more value to developing countries.

\section{Adoption or adaptation?}

The previous two sections show the fragility of the singular narrative implied in the idea of a Korean model. This section identifies one aspect of the Korean experience that has not found its way into the KSP's modularization and that might have been uncovered through policy transfer with intensive stakeholder involvement. In both countries, cultural practices and preferences have demanded the adaptation of imported apartment designs.

The introduction of apartments in Korea was not without resistance. In order for apartment living to transform from aberration to aspiration, significant design changes had to be incorporated. Foremost among these was the rejection of the Western-style baseboard and forced-air heating seen in major early complexes, like Mapo Apartments and Hangang Mansions, in favor of ondol's floor-based radiant heating and the eventual replacement of wood flooring and carpeting with linoleum, which worked better with the radiant heating (Jeon, Yang and Hong, 2009). A second major change was the redesign of floor layouts to reflect traditional housing's courtyard focus by distributing bedrooms and other rooms around a central space that typically unifies the living room and kitchen. Floor plans also introduced a small space inside the apartment entrance for residents and visitors to remove their shoes, a common practice in Korea that is not often seen in the West (Gelézeau, 2012).

While there have been many other minor adaptations and while some evolution may require learning by doing, those adaptations identified here could almost certainly have been incorporated from the beginning through slower, more intensive consultation with potential buyers that worked harder to accommodate rather the override local preferences. It appears that a similar situation holds in Vietnam and that more attention to this adaptive process might have benefited Korean firms' entry into the Vietnamese market.

In building apartments for the Vietnamese market, Korean firms have experimented with a number of different designs and imported a number of Korean preferences and practices. Some designs have fared better than others. All of them appear to be experiencing some friction in integrating into Vietnamese 


\section{Cuz Potter and Jinhee Park}

lives, as they force Korean practices of modernity on Vietnamese tenants that must eventually be adapted to local preferences. Several of them will be discussed here.

This section draws on the focus group interviews and the survey mentioned above. Though summary statistics are not shown here, generally, respondents in Korea were more likely to be older, female, more highly educated, and part of smaller families than Vietnamese respondents. Vietnamese respondents were more likely than Korean respondents to report themselves as enjoying higher or much higher than average incomes and less likely to practice an organized religion. Despite these differences - or perhaps because of them—some fundamental preference distinctions can be identified.

Table 7.1 illustrates some differences in taste between Vietnamese and Korean residents. While both Korean and Vietnamese respondents held that the design of communal space was important, Vietnamese respondents were more likely to emphasize these spaces. This is perhaps related to Vietnam's culture of active street life. Vietnamese respondents were also more likely to emphasize the importance of both modern and traditional design, which poses obvious challenges to architects. While Vietnamese put more emphasis on design, Korean respondents stressed resale value. There appears to be a clear distinction between Vietnamese consumers who are interested in the use value of apartments and Korean consumers who care more about the exchange value. Vietnamese respondents were also more open to higher density environments as a trade-off for proximity to the city center.

Table 7.2 illustrates one additional distinction. While Korean respondents prioritized access to educational facilities over commercial facilities, Vietnamese respondents gave equal emphasis to both. In focus group interviews, Vietnamese

Table 7.1 Relative importance of apartment characteristics in Hanoi and Korea

\begin{tabular}{|c|c|c|c|c|c|c|}
\hline & \multicolumn{3}{|l|}{ Hanoi } & \multicolumn{3}{|l|}{ Korea } \\
\hline & Important & Neutral & $\begin{array}{l}\text { Not } \\
\text { important }\end{array}$ & Important & Neutral & $\begin{array}{l}\text { Not } \\
\text { important }\end{array}$ \\
\hline $\begin{array}{l}\text { Design of communal } \\
\text { space }\end{array}$ & 85.54 & 7.23 & 7.23 & 71.72 & 8.08 & 20.2 \\
\hline Middle floors & 53.01 & 25.3 & 16.87 & 67.68 & 13.13 & 19.19 \\
\hline Higher $>$ lower floors & 48.19 & 18.07 & 28.92 & 54.55 & 20.2 & 25.25 \\
\hline Modern design & 78.31 & 10.84 & 10.84 & 64.65 & 13.13 & 22.22 \\
\hline Traditional design & 61.45 & 27.71 & 9.64 & 21.21 & 26.26 & 51.52 \\
\hline $\begin{array}{l}\text { Developer's } \\
\text { reputation }\end{array}$ & 73.49 & 16.87 & 9.64 & 71.72 & 13.13 & 15.15 \\
\hline $\begin{array}{l}\text { Developer's } \\
\text { nationality }\end{array}$ & 51.81 & 22.89 & 25.3 & 37.37 & 29.29 & 33.33 \\
\hline $\begin{array}{l}\text { Brands on property } \\
\text { value }\end{array}$ & 69.88 & 16.87 & 10.84 & 92.93 & 4.04 & 3.03 \\
\hline Brand value $>$ design & 15.66 & 18.07 & 63.86 & 61.62 & 18.18 & 19.19 \\
\hline Resale value & 32.53 & 37.35 & 27.71 & 88.89 & 3.03 & 8.08 \\
\hline Near city center & 62.65 & 26.51 & 8.43 & 30.3 & 29.29 & 40.4 \\
\hline Low density & 13.25 & 27.71 & 53.01 & 38.38 & 33.33 & 28.28 \\
\hline
\end{tabular}


Table 7.2 Housing priorities in Hanoi and Korea

\begin{tabular}{lccccc}
\hline \multirow{2}{*}{ Priority } & \multicolumn{2}{c}{ Hanoi } & & \multirow{2}{*}{ Korea } \\
\cline { 2 - 3 } \cline { 6 - 6 } \cline { 5 - 6 } & $N$ & Percent & & $N$ & Percent \\
\hline Public transport & 31 & 37.35 & & 36 & 36.36 \\
Driving and parking & 8 & 9.64 & & 8 & 8.08 \\
Park and leisure facilities & 11 & 13.25 & & 16 & 16.16 \\
Education facilities & 15 & 18.07 & & 34 & 34.34 \\
Commercial facilities & 15 & 18.07 & & 5 & 5.05 \\
Community facilities & 3 & 3.61 & & 0 & 0 \\
\hline
\end{tabular}

respondents stressed the importance of living next to traditional markets so that they could purchase fresh cooking ingredients frequently. Therefore, the type of commercial activity is also quite different.

Concrete design issues were highlighted through focus group discussions. These revealed three significant cultural practices that do not harmonize well with designs built by Korean firms. First, despite low rates of religious affiliation, Vietnamese interviewees pointed out that they needed a place for their family altars. Since each home has an ancestral altar, a small, dedicated space is preferred. Among older and more traditional respondents, this space was expected to be positioned according to the rules of feng shui. For younger and less traditional respondents, any designated nook would have been sufficient. As designs built by Korean firms do not provide such a space, ancestral altars wind up wedged among the living-room furniture or in odd corners, creating interior design challenges and an undesirable mixing of sacred and diurnal spaces. Second, while Vietnamese people also choose not to wear shoes indoors, cultural practice dictates leaving shoes outside the house, rather than in the entrance, as in Korea. Therefore, for many Vietnamese, the entrance way space for storing shoes is seen as wasted space and should perhaps be moved outside the apartment into common space.

Most significantly, perhaps, is the importance of ventilation. Vietnamese respondents strongly emphasized the need for good natural ventilation in the apartment. First, doors and windows are typically opened while cooking to remove the smells. Second, like Korea, washed clothes are typically hung out to dry, and Vietnam's humid climate demands good ventilation for this to be effective. Finally, ventilation is essential for cooling in Vietnam. Both to reduce the costs of air conditioning and perhaps echoing the stronger connection to outdoor life in Vietnam's more hospitable climate, respondents stressed the importance of natural ventilation.

The performance of Korean apartments on this count is mixed. Those buildings like Keangnam's Landmark 72 that are built as towers with apartments positioned around a core were viewed highly unfavorably from the perspective of ventilation. Since natural ventilation required opening the apartment door to the common space, residents were troubled by other apartment residents' cooking and noise. Circulation is also weaker, since the common space is closed 
to the outdoors. The major exception were those apartment blocks in Hyundai's Hillstate development that duplicate apartment designs from Korea. Following the pansang design, each apartment has windows on both sides of the apartment, offering exceptionally good natural ventilation.

This exception serves to highlight both the genuine desirability of Korean built apartments and the suitability of many Korean innovations in apartment design. But it does not abrogate the need for culturally sensitive adaptation of contemporary building technology. There are two possible lessons to be drawn from this parallel course of resistance and adaptation. On the one hand, a more detailed examination of the evolution of Korean apartment design may have prompted a more circumspect process of adapting those designs for Vietnamese consumers. Alternatively, if adapting apartment design to new cultural milieux requires experimentation and learning by doing, then the Vietnamese experience adheres more closely to this unrecognized aspect of the Korean model, implying yet another narrative about the Korean experience.

\section{Conclusion}

This chapter has gone through several steps to show that the singular model of Korean development is artificial, weak and of limited utility, even if presented in more detail. It first provided a basic narrative of rapid urbanization and consequent housing shortages addressed through the import of foreign construction technology that would support the notion that Vietnam is following the Korean model as depicted in the modularized Knowledge Sharing Program papers. It then went on to show that though both countries imported foreign expertise in apartment construction, the business structure and knowledge transfer process were substantively different. Maintaining a singular narrative would require conflating the practices of two distinct historical periods, introducing the notion that a new hybrid Korean model could have been constructed to inform policy decisions in Vietnam. The emergence of alternative models was then underlined through an exploration of the adaptation of imported housing designs to local cultural practice, which does not appear in the modularized Korean model. The cultural differences in housing preference between Korean and Vietnamese consumers showed not only that the Korean model obscures some relevant concerns for recipient countries, but also that in broad strokes the process of adaptation may be an applicable component of the Korean model, though in detail the adaptations will be unique to each country.

Thus, we reach the conclusion that while the Korean Knowledge Sharing Program's effort to systematize and modularize the Korean experience into a singular, consistent narrative serves an important role, it constrains the range of rich development experience that the Korean government could share with other countries. If KSP projects were to delve more deeply into the Korean experience hand in hand with stakeholders in recipient countries, then the contextual differences - be they cultural, economic, social, political-between Korea and each of the countries it works with would lead to an emphasis upon 
more relevant facets of Korea's development experience and a unique recombination of those elements. Each country's development history generates its own range of narratives with their own foci and their own concerns. The process of generating new narratives for new futures requires integrating multiple narratives, rather than relying on a singular model. Though contemporary KSP projects propose in-depth collaboration and are thus moving in the right direction, they suffer from severe time constraints, low cultural sensitivity and the seduction of employing the ready-made, modularized policy summaries already available from earlier KSPs. (For a fuller exploration of this argument, see Potter [2019].) If the knowledge sharing process were slowed down and carried out with intensive collaboration of all stakeholders from the earliest stages, then these projects would produce a heteroglossia of narratives, a multitude of models.

\section{References}

Bakhtin, M. (1981). The Dialogic Imagination. Edited by Michael Holquist. Austin: University of Texas Press.

Foucault, M. (1991). Discipline \& Punish: The Birth of the Prison. New York: Vintage Books.

Gelézeau, V. (2012). Republic of Apartments. Translated by Hyeyeon Gil. Seoul: Humanitas. Harms, E. (2016). Luxury and Rubble: Civility and Dispossession in the New Saigon. California: University of California Press.

Howe, B. (2015). "Development Effectiveness: Charting South Korea's Role and Contributions in Middle-Power Korea: Contributions to the Global Agenda," Council on Foreign Relations Press, June.

Jeon, N. I., S. H. Yang and H.-O. Hong (2009). Paju: Hong. Microhistory of Housing in Korea. Paju: Dolbegae.

Kim, H. (2002). "An All-Out War to Receive Orders of New Town Developments in Hanoi," The Kyunghyang Shinmun. July 11. Available at: biz.khan.co.kr/khan_art_ view.html?artid=200207111825301 \&code=920100 [Accessed September 3, 2020].

Korean Institute of Architects (1994). Modern Architecture in Korea 1876-1990. Seoul: Gimundang.

Labbé, D. and C. Musil (2013). "Periurban Land Redevelopment in Vietnam under Market Socialism," Urban Studies 51(6), pp. 1146-1161. doi:10.1177/0042098013495574.

Latour, B. (1990). “Technology is Society Made Durable," The Sociological Review 38(1), pp. 103-131.

Lee, B. (2012). Korean Version of New Town Development. Seoul: Ministry of Strategy and Finance (MOSF), Republic of Korea.

Lee, J. W. (2014). "The Role and Operation of the International Urban Development Cooperation Center," Korea Journal of Construction Engineering and Management 15(3), pp. 10-14.

Lee, K., Y. Kim , J. Ki and H. Shin (2011). Building Technological Capabilities: Four Cases from Manufacturing Sectors in Korea. Seoul: Center for Economic Catch-up, Seoul National University, Republic of Korea.

Nicolas, F., S. Thomsen and M. Bang (2013). "Lessons from Investment Policy Reform in Korea," OECD Working Papers on International Investment, 2013/02 . doi:10.1787/ 5k4376zqcpfl-en. 
Park, C., S. Gwon and S. Lee (2012). "Policy for the Construction and Supply of Affordable Housing in Korea," Technical Report. Korea Research Institute for Human Settlements. Sejong: KRIHS. doi: 11-1051000-000208-01.

Potter, C. (2019). "Just Like Korea in the 1970s? Policy Transfer and the Fiction of Familiarity," International Development and Cooperation Review 11(4), pp. 21-36. doi:10.32580/idcr.2019.11.4.21.

Potter, C. and D. Labbé (2020). "Gentrification or ...? Injustice in large-scale residential projects in Hanoi," Urban Studies, doi:10.1177/0042098020949035.

Yi, I., and T. Mkandawire (2014). Learning from the South Korean Developmental Success. London: Palgrave Macmillan. 


\title{
8 International urban development leadership
}

\author{
Singapore, China and South Korea \\ compared
}

\author{
Hyung Min Kim, Julie Miao and \\ Nicholas A. Phelps
}

\section{Introduction}

Something of a market for the export and import of all things urban has long existed and, as a geographical source of what might be termed "international urban development leadership" has been reinvigorated and expanded significantly in an era of unprecedented international economic integration. Where Western liberal market economies dominated in an Atlantic era of policy exchange in the late 1800s to early 1900s (Rodgers, 1998), East Asian nations have emerged presently as some of the leading sources for the "export" urban expertise of various sorts. Urban development is highly subject to local regulatory frameworks and approvals from local authorities and is dependent upon local market conditions (Squires and Heurkens, 2016). However, there are increasing trends towards transferring some of urban development elements from East Asian nations mostly to developing countries in various formats. Specifically, East Asian nations are notable for the pragmatism and concreteness of their rapid urbanization and industrialization-features that greatly appeal to a wide variety of Global South nations continuing to aspire to greater levels of development (Shin, 2019). Yet, important differences exist among East Asian nations in both the methods of the urban development leadership and the urban expertise involved.

In the chapter we draw together findings from our previous research (Miao and Phelps, 2019; Miao, 2018), ongoing fieldwork in South Korea and the extant literature to compare and contrast facets of the different approaches to urban development leadership among selected East Asian countries. We observe important contrasts among the countries, including the extent to which any models of leadership or export of urban solutions are clearly defined or not. The observation underlines the thought that (East) Asia as a method (Chen, 2010) can be revealing both of important intra-regional difference and some of the features around which urban future studies scholarship be refocused away from extant concerns with Western liberal models and notions of leadership. 


\section{Urban leadership beyond the Atlantic}

To judge by the relative weight of academic literature, much of our understanding of leadership with regard to municipal finance, management and planning and other policies continues to emanate from the liberal market economies of the West with exchange occurring across the Atlantic axis in particular. Doubtless, the weight of history and accumulated expertise borne of early industrialization, urbanization and modern state formation in Europe and North America continues to exert itself well after the Atlantic era highpoint of policy exchange (Rodgers, 1998) of the late 1800s and early 1900s. Policy exchange across the Atlantic and among liberal market economies continues to be intense in terms of innovations in the management and delivery of urban services but also headline policies such as the likes of enterprise zones, business improvement districts, tax increment financing, city deals and the like.

However, it is also apparent that the East Asian "Tiger" states have emerged in the last decades as important models of urban development with wider appeal, including in the West (Mahutga et al., 2010). Singapore is perhaps the best known among these East Asian nations as a global reference point for urban solutions but others-Japan, South Korea and China-have also emerged. All of which suggests the need to examine more closely the basis and features of such leadership in the urban sphere. As these East Asian nations tackled urban challenges borne of rapid industrialization and urbanization mostly from the 1970s to the 1990s, they have gained know-how, confidence, capital, managerial, civil engineering and technological skills, as 'reference points' (Shin, 2019), enough to expand (or 'export') their urban development models to developing countries that are currently facing urban issues that those East Asian nations experienced before.

The term "international urban development leadership" is used as an umbrella term in this chapter to refer to the overarching influence of cities in transferring demonstratable best practices to other countries, including both tangible and intangible components such as policy sharing, training for government officials, consultation for urban projects, the construction of urban infrastructure, IT urban solutions and new town development. While the term "international cooperation" largely displays horizontal interactions between countries, "leadership" conveys a nuanced form of hierarchy within urban systems. A passive way of executing the leadership involves flows of ideas and policy such as public diplomacy, which is not too far from exerting soft power in the urban management scene (Miao, 2018). But an active way can also involve flows of capital investments and technologies through foreign direct investment (FDI), trade and international aid (or Official Development Assistance (ODA)) that can be eventually expressed in the operation and the management of cities and built environments in the recipient cities.

Due to the resources required for urban development leadership, the approaches taken by the "leader" countries have followed "pragmatism" with variations in terms of (1) timing, (2) form, (3) emphasis, (4) administration and 
(5) geopolitics (see Appendix 1). These five inter-related categories are useful in specifying their urban leadership models. Japan and, to a certain extent, Taiwan are key actors in East Asia, but due to limited space, this chapter reviews three East Asian nations: Singapore, China and South Korea. Their cities have undertaken rapid urbanization, seen a notable rise in economic potency and established extensive international networks, which are reflected in the escalation in the world urban system.

The policy exchange of the Atlantic era was subject to many of the imperfections characterized by lofty aspirations of enlightenment, improvement, modernity and progress. In practice, the urban development leadership of this era resulted in urban planning solutions that were overly concerned with aesthetics, order, formality and symmetry which today sit uncomfortably with conditions in, and are recognized as inappropriate for, Global South nations (Watson, 2009). By contrast, and regardless of the contested current status of the states concerned as post-developmental, the urban leadership provided by East Asian states has been altogether more pragmatic and emanating from their earlier developmental credentials. Indeed, it is the demonstrated efficacy of rapid industrialization and urbanization-rapid modernization-that most appeals to those nations and cities seeking to import solutions from East Asian "tigers" when compared to the socially progressive idealism that characterized (at least for a time) the earlier trans-Atlantic exchange of policy and practice. Then again, that pragmatism actually has several East Asian faces.

\section{Variations on the theme of pragmatism}

\section{Timing}

The different developmental state models achieved international prominencein the form of the international competitiveness of key industries - at different periods with predictable consequences for the accumulation of expertise and the timing of acknowledged leadership in the urban sector specifically. However, it is also true to say that the states involved have been quicker or slower to consciously project that leadership as a diplomatic effort, or export earner. For example, Japan's early industrial and export leadership among East Asian tigers dating from the 1960s-1980s has perhaps not at any time resulted in the acknowledged leadership role in urban services specifically, although towards the end of the 1980s Japan did reach out to Australia in selling a dream of building the first, yet short-lived, multifunction polis (Chan, 2015). In the context of a now stagnant economy and one experiencing elements of urban population decline, it seems difficult for Japan to assert its leadership since the 1990s.

Singapore's leadership by today has been slower to emerge but arguably has been consciously shaped from relatively early on. In some respects, the clarity of the Singapore model was foretold in the Lee Kuan Yew's vision of Singapore being a city in a tropical garden- "a city in a garden"-and enacted from a studied, highly deliberate and increasingly commercially driven "borrowing" and further 


\section{Hyung Min Kim et al.}

development of practices gleaned from overseas (Han, 2005). While Singapore's identification of its leadership in smart and sustainable urban solutions is itself quite recent, we date the leadership to the 1980s, when with the overheating of the domestic economy, Singaporean government bodies really began to move beyond the national territory with the development of overseas industrial parks such as the Suzhou Industrial Park (SIP) in China (Pereira, 2003; Phelps, 2007). These were absolutely integral to the honing of the model as it has come to be refined and exploited abroad.

China's urban leadership might arguably be said to have leapfrogged the rest of the economy since, regardless of the potential domestic real estate bubble, the sheer scale and pace of urbanization has propelled its real estate and urban solutions to the forefront of sectors in which it has international competitive advantage. The former fishing town of Shenzhen started China's urban transformation, and like Singapore, China was willing to take on any possible urban development practices. Yet for cultural and ideological reasons, Hong Kong was, of course, a preferred reference in a transition towards modern, urbanized China (Zhang, 2012) and a Singaporean model was also adopted in flagship development projects (Caprotti, 2014; Kim and Cocks, 2018). Thirty years later, Shenzhen, itself, and other successful urban development projects have become a legacy, and the Chinese national and local governments are grasping quickly the market values of it. As many African countries are looking for urban development strategies and solutions, Chinese industrial and/or processing zones have become a reference for them since the 2010s (Brautigam and Tang, 2011; Dannenberg, Yejoo and Schiller, 2013). China's overarching influence has been escalated by Belt and Road Initiatives (BRIs) through infrastructure investment.

South Korea's economic performance matches, and the scale and diversity of its domestic economy far exceeds that of Singapore. However, the exertion of a leadership role in urban development sector has been belated by comparison. Despite focused and successful examples of innovation and leadership in the IT and urban development sectors - such as the Information and Telecommunication Technology Program (ITTP) launched from KAIST in the mid-2000s (Kang and Park, 2017) and the International Urban Development Program from the University of Seoul in the early 2010s-the aspirations of South Korean institutions taken as a whole have only emerged in earnest in the last few years. In tandem with offering training programs, the 2010s has witnessed the proliferation of government initiatives for transferring Korean urban policy and urban development as best illustrated in the South Saad Al Abdullah Smart City (SSAA) project in Kuwait that South Korean planning institutions have played a leadership role from the 2010s (Jung, 2019).

\section{Form}

The substantive depth of the export as indicated in the form of involvement also varies across East Asian states. In each of the states we reviewed, FDI flows 
parallel the sorts of international flows represented by urban development leadership. However, that relationship has varied in terms of its direct or indirect contribution.

Singapore's leadership was honed precisely in a series of overseas Governmentto-Government (G2G) ventures in which it was Singapore real estate and planning hardware that was exported in the form of both indirect consulting and training services, such as the "Temasek Foundation International Leaders in Urban Governance Program for Asia" coordinated by the Centre for Livable Cities Singapore; and direct development and physical constructions by government linked companies (e.g., those belong to the Singapore Housing Development Board (HDB)) or newly privatized versions of former government linked companies (e.g., Sembcorp Development Ltd). Indeed, the opportunities for and experience of developing abroad directly contributed to the privatization process of those government linked companies involved with the built environment, housing and other real estate development and management. From its inception, these overseas projects were designed to provide an organized means for the offshoring of foreign manufacturing industries that had been operating in Singapore (Phelps, 2007) but evolved further into supporting exports and FDI by Singaporean companies and further still into a series of non-physical investments in listening posts in overseas countries such as China (Miao, 2018).

To an extent, China has mimicked this process of physical real estate and facilities management presence abroad but with less of a focus on a precisely, let alone consistently, codified hardware and management software. This is perhaps not surprising as China has accumulated excessive production capacity in iron and steel, as well as construction experience especially in wholesale physical space constructions and extensive high-speed railways. At the same time, given the large and diverse nature of the domestic economy, the development of projects abroad in the likes of several African countries has been accompanied by larger and more diverse flows of FDI. It has become more and more obvious that the Chinese central government tries to pass on investment risks to local governments and their associated investment bodies. In the first bunch of approved African Industrial Park projects, for example, almost half were explicitly led by a local public-private sector consortium, and the rest were shouldered by a few major private companies which in turn have close relationships with their local governments.

South Korean companies have a significant recent history of outward FDI in countries across the Asian region including China, Hong Kong and Vietnam that have preceded and remained largely disconnected from more recent initiatives to go abroad with urban leadership (Kim, 2020). Moreover, the approach as currently articulated does not appear to demonstrate this close connection as is the case with Singapore and China, implying current government approaches to "going abroad" are fragmented and uncoordinated with limited capacity to lead outward FDI of private firms to date. 


\section{Emphasis}

Much of the emphasis found in the Singaporean model reflects the vulnerabilities of small island state and the relatively slender and specific niche opportunities that can be exploited by businesses. From the outset the economy has been the first priority of the Singapore government. This has translated into a careful selection and curation of Singapore's competitive advantages. The common refrain heard among public servants in Singapore is that best use needs to be made of very limited resources; but in the face of enormous interest in the city-state's transition from third world to first, this has taken on a very strong commercial focus not found elsewhere. It involves the identification, testing and monitoring and perfection of business models based on specific expertise including that emanating from within government bureaucracies and government linked companies (familiar as part of development state approaches, which are retained in Singapore even if partially abandoned elsewhere). It also more recently has involved the generation of fees from conferences, training programs and bespoke consulting based on the Singapore story but also for the many visitations that often are hosted for free by local and national governments around the world as normal diplomatic activities. The model remains a tightly guarded one, partly given the very thin domestic business ecosystem in Singapore.

China's urban development leadership is driven largely by "vent for domestic surpluses" (Myint, 1958) across both the private and public sectors. Moreover, those surpluses are themselves specifically related to real estate development which national, local governments and private sectors have. These surpluses generated from land leasing revenues from the rapid and massive development of land required for China's urban transition have accrued to local and national governments while the profits from the house construction and owner-occupier boom have fueled private sectors in scale and profitability. As the urbanization rate tails off, governments and private sector construction companies and real estate developers are in search of overseas markets which they have found significantly in Africa, but also more recently across the BRIs- the Silk Road Economic Belt and the 21st-century Maritime Silk Road.

The South Korean model of "going abroad" does have a commercial aspect but is very much one driven in the first instance, rhetorically at least, by its commitment or obligations as a past recipient of significant development and reconstruction aid money. Thus, commercialization and export, let alone profit and competitive advantage, are not words that are commonly used in connection with South Korean urban development leadership.

Nevertheless, technical assistance and other aid-funded projects are considered a way to channel opportunities to the wider ecosystem of businesses in South Korea. In the wake of restrictions on the chaebol companies bidding for public procurement contracts domestically, the external facing opportunities also exist with supporting the export and outward FDI activities of domestic small- and medium-size enterprises (SMEs). The SMEs are linked with chaebols such as Samsung and LG for IT solutions and Daewoo, Hyundai and POSCO for 
construction and real estate development left to undertake their own export and FDI work directly and independently apart from public sector institutions. Here the model appears similar to that in Finland where, in the wake of the dissolution of the national champion Nokia, the emphasis has been upon building a new cohort of industry leaders from the wider ecosystem of SMEs.

While Korean private sectors have been proactive in international real estate development for profit-maximizing and diversifying their revenue sources (Kim, O'Connor and Han, 2015), public institutions have been restrained within institutional frameworks such as parliamentary audits. Any risk-taking entrepreneurial initiatives by public sectors can easily be a subject of public criticism. Their rate of return on entrepreneurial projects should neither outperform nor underperform to avoid public disputes. Given limited institutional capacity in playing their role, what they can do is to leverage public funds that can not only support recipient countries, but also invite Korean private firms in ICT and/or urban development sectors. As cross-border business activities are perceived risky, especially in urban sectors due to uncertainties in local politics, regulations and economies (Kim, O'Connor and Han, 2015), these public sectors play a role in lessening business risks for participating private firms by granting funds for aid-associated urban projects and establishing G2G agreements. Korean cities have undertaken trial and error to tackle urban problems borne of unprecedented urbanization. By virtue of accumulated skills and experiences, the current emphasis is upon on (1) new town development and (2) ICT sectors (that can be translated into smart cities in built environments). One of the notable approaches is new town development led by public agencies such as Korea Land and Housing Corporation (LH) (La Grange and Jung, 2004).

Although these greenfield development projects have been criticized due to their unsustainable urban form (Jun and Hur, 2001), these were appealing for developing countries because governments led and directed housing supply, the new development sites provided livable environments for the middle class away from crowded old urban fabric and the entire development process was very fast. A more recent Korean planning approach has been the making of smart cities, firstly named "Ubiquitous City" (or "U-City") within South Korea from the mid-2000s (Kim and Kim, 2013). The confidence of Korean smart cities has been flagged and accelerated by advancement in ICT. Despite the underperformance of initial smart city projects such as Songdo (Shin, Park and Sonn, 2015), smart city initiatives have been pervasive in most flagship development projects such as Sejong New Town and Eco Delta City in Pusan in search of IT urban solutions (Choi and Kim, 2021). These accumulated planning experiences have become major sources to claim urban development leadership in developing countries.

\section{Administration}

The Singapore model is one that by now is highly codified down to the level of some of its individual constituent parts such as neighborhood planning principles, $\mathrm{HDB}$ and welfare systems and even the "software" of public administration and 
management systems. Its first government-to-government collaboration with China, the Sino-Singapore Suzhou Industrial Park (SIP), for example, involved three stages of "knowledge transfers" starting from physical planning, to project construction and then long-term management skills (Miao, 2018). One irony is that significant elements of this model were imported in the first instance as classical principles of land reclamation and investment promotion. Land value capture was refined in what could be regarded as the representative "urban laboratory". Of course these learnt practices have been overlain by important elements of state intrapreneuralism (Miao and Phelps, 2019) regarding the identification, testing, monitoring, honing and maximizing of the, sometimes slender, economic niches conferred by island nation status. Innovative thinking here has centered significantly on identifying and exploiting the opportunities for extraterritoriality (Phelps, 2007). Curiously, however, Singapore's strength is at the same time its weakness. Its model is highly codified and is so closely associated with its city-state domestic origins including a very thin private sector base that it can fail, and has failed, to travel well even in apparently ethnically and culturally similar contexts such as China, where the problems with the SIP and rival parks have been reported (Yeung, 2000). Open questions remain here about the extent to which the Singapore model can evolve to reflect the overseas influences with there being some anecdotal evidence that this is the case (Miao, 2018).

It is little appreciated that, despite single party rule and important elements of national planning and significant financial might, China constitutes a very decentralized nation in terms of all matters urban and economic (Yeh and $\mathrm{Wu}$, 1999). Opening up (and subsequent) reforms licensed significant local initiatives, albeit that, to date, this is not especially innovative or varied across China-it often involving the mimicking of a successful experiment partly encouraged by central government incentives in a series of policy "fevers"-special economic zones, new districts and towns, featured towns and the like (Yang and Wang, 2008). In this process entrepreneurial local governments typically lead in the conception, assembly, planning and partnering with favored private sector developers (Kim and Kent, 2019). There is little doubt that the vast scale and pace of urbanization, coupled with the licensing of local initiative, has facilitated the rapid accumulation of significant experience and scaling up of national champion construction, infrastructure and planning institutes and development companies. For example, the Shanghai Planning Bureau first adopted the concept of strategic planning (Wu and Zhang, 2007), which sits outside the statutory legislations, hence it offered local policymakers significant room for re-imagining their territorial boundary. Such freedom and acclaimed long-term macro-control of urban development soon attracted followers from other cities and provinces. Now almost every Chinese city prepares a strategic plan besides the required five-year urban development and land use plans. Yet as mentioned before, the regional diversity in China is big enough in generating a measure of variety in public-private partnerships. These varieties and complexities are reflected in a number of regional and local business "models" such as the Wenzhou and Sunan models found within the Yangtze River Delta region, which feature unique administrative arrangements in building 
their urban development leaderships (Wei, Li and Wang, 2007; Wei, 2002). An intriguing question for future research work is whether these distinct models will be preserved, modified and amplified to find expression overseas.

We have described South Korea's administration of its urban leadership as "pick and mix" in which the appropriateness of urban and technological solutions to the host context is emphasized strongly. This has been important in the South Korean context since it has begun to engage rapidly with a diverse range of often developing countries as a result of the focus on channeling its global efforts through aid and technical assistance. Here, the lack of a model and the institutional strength but complexity of South Korea is something of an advantage albeit that it may conflict with emerging efforts to promote the country's leadership. It is unclear whether the top-tier city, Seoul, is synonymous with or a stronger urban leadership brand than the nation. To counteract some of these confusions the term "Team Korea" has been instituted to try to avoid wasteful duplication and overlap among many organizations operating in the same urban development leadership space, although no discernible control tower among government sectors is established. At a national level, the Ministry of Economy and Finance oversees and approves budgets of public institutions, having an only implicit, indirect authority for coordination, while there is proliferation of "going abroad" initiatives undertaken by public institutions and agencies. Korea International Cooperation Agency (KOICA) establishes strategies for Korean ODA, funds international development projects and builds up bi- and multi-lateral relationships with aid recipient countries. Despite KOICA's significant position in distributing aid money, it is not an agency to coordinate public institutions involving "going abroad" and urban sectors have been de-emphasized in its priority.

\section{Geopolitics}

The geopolitical strategies within which the urban development leadership takes their cue vary across the three states being considered. As noted, the strength of Singapore derives significantly from the tight focus brought by the perceived insecurities but also opportunities presented as both a small state and an island state. The peculiar advantages including the deft exploitation of economic niches have been noted elsewhere (Baldacchino, 2010; Chong, 2009). Moreover, it can be argued that Singapore, by emphasizing its status as a city-state, has managed to escape from some of the major power conflicts in the Pacific Rim and the associated mega power (re)balancing. Its understated geopolitical significance, coupled with its crucial geographical location, is one of the key contexts that underpin the momentum of its economic growth.

Contrasted sharply with Singapore, there have been overblown concerns over China's increasing geopolitical and geo-economic influence not only in Asia Pacific but worldwide. Yet these concerns probably ought to be tempered by recognition of the ancient history, scale and reach of the Chinese diaspora (Tölölyan, 1996). Nevertheless, it is fair to say that China's urban development leadership is hardly separable from the largest of large state geopolitical/ 
geo-economic strategies-the BRIs (Liu and Dunford, 2016). The rhetoric of $\mathrm{BRI}$ is steadfastly one of the inclusive partnerships for prosperity and doubtless the debate about any intentions and the long-term effect of the enormous flows of aid and loan money will continue to be had. There are by now 125 countries and 29 international organizations that have signed 173 cooperation agreements. Such wide geopolitical reach of BRIs means that it is extremely inclusive of very different business systems and national economic development models from the mixed market, social democratic models of, say, Germany, to transition economies of Eurasia, to would-be African developmental states (such as Ethiopia and Ghana), and to countries commonly regarded as "vampire" or "predatory" states. There is a plan of more than $\$ 1$ trillion investment associated with BRI projects, waiting for willing cities and countries to bid for. As such, the potential recursive influences on China's urban development leadership are perhaps the most diverse of any country worldwide-though this diversity may itself be a barrier to meaningful crystallization and evolution of a distinct set of Chinese models of urban development leadership-except a wider urban development spread under China's leadership.

Any distinct South Korea model is as yet poorly articulated as we noted above. But the geopolitical context is one of a state that is caught between East and West and between neoliberal and socialist geopolitical faces. This, in turn, may account for the apparent neutrality or multi-laterality of South Korea's going abroad. The scale and the diversity may not be compatible with those in surrounding influential East Asian nations like China and Japan. South Korean modern development history, however, claims to become an exemplar for developing countries as a comprehensive decent-sized state different from a city-state of Singapore and, also from a gigantic nation of China. Korean cities underwent colonization, decolonization, the Cold War, urbanization, suburbanization, industrialization, globalization, and deindustrialization within a short period time by which developing countries are motivated to grasp any sorts of lessons (Kim and Han, 2012).

\section{Conclusion}

East Asia's urban development leadership appears to have come upon us all of a sudden. However, it has been in the making for some time and has its lineages in the developmentalism that many see as now truly part of the past of these nations.

East Asian states vary also in the extent to which a coherent model of urban leadership exists. A defined Singapore "money-making” model exists for a number of reasons. Most importantly is that the state in consideration is a city and so there is no territorial politics associated with the promotion of unified and well-crafted urban solutions. This is amplified by de facto single-party rule which has allowed for a degree of policy continuity hardly approached anywhere else in the world and allied to the geopolitical focus of a small island state. At the other extreme, the scale and diversity of China and the sheer speed at which experimentation has taken place within China ensure that no real model exists as such (Wu, 2017). The "money-giving" is mystified further by the greater degree of decentralization 
in the export of urban and infrastructure than often appreciated in a seemingly centralized, single-party state. Many localized models may exist, though it may be too early to discern these. It may still be no exaggeration to say that China overtly imitated Singapore's overseas industrial parks, but several decades later China does it in a more decentralized form found across African nations (Brautigam and Xiaoyang, 2012). South Korea stands in between in the sense that there are now significant issues of national territorial management and associated politics, an extensive and complex set of public authorities with some interest in urban services and significant shifts in national politics. While no obvious model can be discerned to date, Korean academics and have paid attention to defining core elements of Korean urban development models (including this book) (Kim et al., 2009). Due to the lack of consensus about a Korean urban development model, institutions have varying, fragmented approaches. From our interviews, "going abroad" was couched very much in terms of the sharing and repaying of opportunities and obligations of aid while the use of the term "export" was debatable due to the nature of localized urban development industries. Of course, the term "export" may be a convenient cover for local citizens and tax payers due to its "money-leveraging" intentions, but there appears a strong element of truth in that many of the major public institutions, city governments and national ministries and research organizations are involved dominantly in those projects for which compelling cases are mounted via donors and aid agencies. The emergence of Korean urban development leadership has been aligned with the growth of the volume of aid towards developing countries. The volume of Korean net ODA was 0.02-0.07 percent of Gross National Income (GNI) in the 1990s, but it gradually increased to 0.16 percent of Gross National Income (GNI) or USD 2.4 billion in 2016 (OECD). The growth of Korean national economic size meant expanding ODA capacity that has greater potential for urban development leadership.

The three East Asian nations considered present three rather different approaches though, for differing reasons, they do converge in some aspects of their models. For example, China and Singapore's emphasis on physical real estate development and management as a main means of drawing in wider opportunities seem to contrast with South Korea's efforts to go abroad in the forms of technical assistance projects. Nevertheless, as a result of involvement with new town planning and development exemplified in SSAA, there is present interest that this specific expertise can be mobilized and with it presumably the possibility for broad-based flows of South Korean FDI in real estate to follow.

Here we have sought to outline some of the diversity of pragmatism found across East Asia and we doubtless could go further with some of our investigations and discussions. How these different East Asian models (or non-models) crossfertilize as intra-regional hosts and homes and further afield in host contexts outside the region remains to be seen. Ironically, the very pragmatism that is the foundation of urban leadership may for various reasons not adapt. There is some evidence that Singapore's highly codified model has been adapted partly through the necessity of preserving a competitive edge in the slender niche markets in which it claims a lead. Here learning is very much part of a monitoring and 


\section{Hyung Min Kim et al.}

development process that is itself highly codified and in which knowledge and expertise is carefully curated and guarded. South Korea's "pick and mix" offering appears as yet to be oriented to supplying urban and information technology solutions rather than re-adapting solutions that exist. As a highly trading diaspora with an ancient global lineage, one would expect China's various models to become adapted to local circumstances but whether overseas experiences will be reflected in adaptation domestically is still unclear.

\section{Appendix 1: contrasts in the approaches of several East Asian nations to the export of urban solutions}

\begin{tabular}{|c|c|c|c|}
\hline & Singapore & China & S. Korea \\
\hline Timing & $1980 s-$ & $2000 s-$ & $2010-$ \\
\hline Form & $\begin{array}{l}\text { Direct investment } \\
\text { in overseas real } \\
\text { estate development } \\
\text { (hardware } \\
\text { and software) } \\
\text { leads MNEs } \\
\text { and Singapore } \\
\text { companies overseas. }\end{array}$ & $\begin{array}{l}\text { Direct investment } \\
\text { in overseas real } \\
\text { estate development } \\
\text { (hardware) leads full } \\
\text { package of FDI in } \\
\text { manufacturing and } \\
\text { consumer sectors. }\end{array}$ & $\begin{array}{l}\text { The provision of } \\
\text { technical assistance } \\
\text { and consulting. }\end{array}$ \\
\hline Emphasis & $\begin{array}{l}\text { "Money- } \\
\text { making": strong } \\
\text { commercial focus } \\
\text { on "bottom line" } \\
\text { revenue generation } \\
\text { from international } \\
\text { urban development } \\
\text { leadership. }\end{array}$ & $\begin{array}{l}\text { "Money- } \\
\text { giving": "Vent for } \\
\text { surplus" (Myint, } \\
\text { 1958). Private } \\
\text { surpluses in real } \\
\text { estate in search of } \\
\text { new markets and } \\
\text { export of domestic } \\
\text { labour. Public } \\
\text { surpluses in the } \\
\text { form of aid and } \\
\text { loans. }\end{array}$ & $\begin{array}{l}\text { "Money-leveraging": } \\
\text { "Technical assistance" } \\
\text { as enabler of } \\
\text { exports and FDI } \\
\text { opportunities for } \\
\text { private firms. }\end{array}$ \\
\hline Administration & $\begin{array}{l}\text { Highly codified } \\
\text { domestic model } \\
\text { of hardware and } \\
\text { administrative } \\
\text { software with some } \\
\text { modest adaptation } \\
\text { from overseas } \\
\text { experiences. }\end{array}$ & $\begin{array}{l}\text { Financial umbrella } \\
\text { of aid and loans of } \\
\text { BRI. }\end{array}$ & $\begin{array}{l}\text { Overlapping and } \\
\text { competing national, } \\
\text { city and sectoral } \\
\text { public sector interests. } \\
\text { Pick and mix of } \\
\text { appropriate solutions } \\
\text { from wide variety } \\
\text { of urban and ICT- } \\
\text { related solutions. }\end{array}$ \\
\hline Geopolitics & $\begin{array}{l}\text { Small/island state } \\
\text { mobilization of } \\
\text { economic niches. }\end{array}$ & $\begin{array}{l}\text { Conventional big state } \\
\text { realist geopolitics } \\
\text { of incentivizing and } \\
\text { enforcing major } \\
\text { political alliances. }\end{array}$ & $\begin{array}{l}\text { Relative neutrality } \\
\text { within multi-lateral } \\
\text { organizations and } \\
\text { agreements. }\end{array}$ \\
\hline
\end{tabular}




\section{Acknowledgments}

This research was supported by the British Academy and Regional Studies Association's Early Career Grant Scheme (November 2013 Round) and the Academy of Korean Studies (AKS-2019-R35).

\section{References}

Baldacchino, G. (2010). Island Enclaves: Offshoring Strategies, Creative Governance, and Subnational Island Jurisdictions. Montreal: McGill-Queen's Press-MQUP.

Brautigam, D. and X. Tang (2011). "African Shenzhen: China's Special Economic Zones in Africa," Journal of Modern African Studies 49, pp. 27-54.

Brautigam, D. and T. Xiaoyang (2012). "Economic Statecraft in China's New Overseas Special Economic Zones: Soft Power, Business or Resource Security?” International Affairs 88, pp. 799-816.

Caprotti, F. (2014). "Critical Research on Eco-Cities? A Walk Through the Sino-Singapore Tianjin Eco-City, China," Cities 36, pp. 10-17.

Chan, G. (2015). “Cabinet Papers Reveal Confusion Over 'Vague' Plan to Build Futuristic Japanese City in Australia," The Guardian. Available at: www.theguardian.com/ australia-news $/ 2015 / \mathrm{jan} / 01 /$ cabinet-papers-reveal-confusion-over-vague-plan-tobuild-futuristic-japanese-city-in-australia. [Accessed September 10, 2020].

Chen, K. H. (2010). Asia as Method: Toward Deimperialization. Durham and London: Duke University Press.

Choi, J. and H. M. Kim (2021). "State-of-the-art of Korean Smart Cities: A Critical Review of the Sejong Smart City Plan," in H. Kim, S. Sabri and A. Kent (eds.), Smart Cities for Technological and Social Innovation. Oxford: Academic Press, pp. 51-72.

Chong, A. (2009). "Singapore and the Soft Power Experience," in A. F. Cooper, and T. M. Shaw (eds.), The Diplomacies of Small States. Basingstoke: Springer, pp. 65-80.

Dannenberg, P., K. Yejoo and D. Schiller (2013). "Chinese Special Economic Zones in Africa: A New Species of Globalisation?" African East-Asian Affairs 2, pp. 4-14.

Han, S. S. (2005). "Global City Making in Singapore: A Real Estate Perspective," Progress in Planning 64, pp. 69-175.

Jun, M. J. and J. W. Hur (2001). "Commuting Costs of 'Leap-Frog' New Town Development in Seoul," Cities 18, pp. 151-158.

Jung, S. (2019). Effort for the Export of Cities. Urban Information Service. Seoul: Korean Planning Association (in Korean).

Kang, D. and M. J. Park (2017). "Competitive Prospects of Graduate Program on the Integration of ICT Superiority, Higher Education, and International Aid," Telematics and Informatics 34, pp. 1625-1637.

Kim, H. M. (2020). "International Real Estate Investment and Urban Development: An analysis of Korean Activities in Hanoi, Vietnam," Land Use Policy 94, pp. 1-10, 104486 (Land Use Policy article no.).

Kim, H. M. and M. Cocks (2018). "Urbanisation and Globalisation: An Overview of Modern Suzhou Development," in S. S. Han and W. Lin (eds.), Healthy Future Cities. Beijing: China Architecture Industry Press, pp. 379-395.

Kim, H. M. and S. S. Han (2012). "Seoul," Cities 29, pp. 142-154.

Kim, H. M. and A. Kent (2019). "The Emergence of International Urban Planning and Design Firms in China from an OLI Perspective," Journal of Regional and City Planning 30, pp. 123-139. 


\section{Hyung Min Kim et al.}

Kim, H. M. and T. S. Kim (2013). "U-City Development for Economic Competitiveness in an Advanced ICT Era," in G. Boscarino, and D. Notte (eds.), Economic Developments and Emerging Markets of the 21st Century: Global Practices, Strategies, and Challenges. New York: Nova, 245-264.

Kim, H. M., K. B. O'Connor and S. S. Han (2015). "The Spatial Characteristics of Global Property Investment in Seoul: A Case Study of the Office Market," Progress in Planning 97, pp. 1-42.

Kim, S. H., H. S. Kim, M. W. Lee, K. J. Paek and J. W. Lee (2009). The New Visions and Strategies for National Territorial Development Model of Korea. An-Yang: Korea Research Institute of Human Settlements (in Korean).

La Grang, A. and H. N. Jung (2004). "The Commodification of Land and Housing: The Case of South Korea," Housing Studies 19, pp. 557-580.

Liu, W. and M. Dunford (2016). "Inclusive Globalization: Unpacking China's Belt and Road Initiative," Area Development and Policy 1, pp. 323-340.

Mahutga, M. C., M. Xiulian, D. A. Smith and M. Timberlake (2010). "Economic Globalisation and the Structure of the World City System: The Case of Airline Passenger Data," Urban Studies 47, pp. 1925-1947.

Miao, J. T. (2018). "Parallelism and Evolution in Transnational Policy Transfer Networks: The Case of Sino-Singapore Suzhou Industrial Park (SIP)," Regional Studies 52, pp. 1191-1200.

Miao, J. T. and N. A. Phelps (2019). “The Intrapreneurial State: Singapore's Emergence in the Smart and Sustainable Urban Solutions Field," Territory, Politics, Governance 7, pp. 316-335.

Myint, H. (1958). "The 'Classical Theory' of International Trade and the Underdeveloped Countries," The Economic Journal 68, p. 317.

$\operatorname{OECD}(2020)$ Net ODA (indicator) doi: 10.1787/33346549-en. [Accessed September 10, 2020].

Pereira, A. A. (2003). State Collaboration and Development Strategies in China: The Case of the China-Singapore Suzhou Industrial Park (1992-2002). London: RoutledgeCurzon.

Phelps, N. A. (2007). "Gaining from Globalization? State Extraterritoriality and Domestic Economic Impacts-The Case of Singapore," Economic Geography 83, pp. 371-393.

Rodgers, D. T. (1998). Atlantic Crossings. Cambridge MA, Harvard University Press.

Shin, H., S. H. Park and J. W. Sonn (2015). "The Emergence of a Multiscalar Growth Regime and Scalar Tension: The Politics of Urban Development in Songdo New City, South Korea. Environment and Planning C," Government and Policy 33, pp. $1618-1638$.

Shin, H. B. (2019). "Asian Urbanism," in A. M. Orum (ed.), The Wiley-Blackwell Encyclopedia of Urban and Regional Studies. Hoboken, NJ: Wiley-Blackwell, pp. 1-10

Squires, G. and E. Heurkens (2016). "Methods and Models for International Comparative Approaches to Real Estate Development," Land Use Policy 50, pp. 573-581.

Tölölyan K. (1996). "Rethinking Diaspora(s): Stateless Power in the Transnational Moment. Diaspora," A Journal of Transnational Studies 5, pp. 3-36.

Watson, V. (2009). "Seeing from the South: Refocusing Urban Planning on the Globe's Central Urban Issues," Urban Studies 46, pp. 2259-2275.

Wei, Y. D. (2002). "Beyond the Sunan Model: Trajectory and Underlying Factors of Development in Kunshan, China," Environment and Planning A 34, pp. 1725-1747.

Wei, Y. D., W. Li and C. Wang (2007). "Restructuring Industrial Districts, Scaling Up Regional Development: A Study of the Wenzhou Model, China," Economic Geography 83, pp. 421-444. 
Wu, F. (2017). "State Entrepreneurialism in Urban China: A Critique of the Neoliberal City," in G. Pinson and C. M. Journel (eds.), Debating the Neoliberal City. Oxon and New York: Routledge, pp. 163-183

Wu, F. and J. Zhang, (2007). "Planning the Competitive City-Region: The Emergence of Strategic Development Plan in China," Urban Affairs Review 42, pp. 714-740.

Yang, D. Y. R. and H. K. Wang (2008). "Dilemmas of Local Governance under the Development Zone Fever in China: A Case Study of the Suzhou Region," Urban Studies 45, pp. 1037-1054.

Yeh, A. G. O. and F. Wu (1999). "The Transformation of the Urban Planning System in China from a Centrally-Planned to Transitional Economy," Progress in Planning 51, pp. 165-252.

Yeung, H. W. C. (2000). “Local Politics and Foreign Ventures in China's Transitional Economy: The Political Economy of Singaporean Investments in China," Political Geography, 809.

Zhang, J. (2012). "From Hong Kong's Capitalist Fundamentals to Singapore's Authoritarian Governance: The Policy Mobility of Neo-Liberalising Shenzhen, China," Urban Studies 49, pp. 2853-2871. 
$\because$ Taylor \& Francis Taylor \& Francis Group http://taylorandfrancis.com 


\section{Part III \\ Policies and institutions of Korean urban development}


$\because$ Taylor \& Francis Taylor \& Francis Group http://taylorandfrancis.com 


\title{
9 Exporting new city developments? From new towns to smart cities
}

\author{
Yu-Min Joo
}

\section{Introduction}

In 2011, I stumbled upon a newspaper article titled "The Korean wave of apartments: It is now an era of new city exports" (Hwang, 2011). It pointed out that there is an interest for new city developments overseas that were "made by Korea". A number of Asian, Middle Eastern and African countries are finding South Korean companies' know-how and experiences in building new towns (or new cities) appealing. In fact, new town developments have been the major urban megaprojects of South Korea (hereafter "Korea") which have allowed the country to rapidly urbanize within just 30 years: In 1960, only 28 percent of Koreans were living in urban areas but the percentage jumped to 74.4 percent by 1990. Despite new towns being risky and expensive projects requiring long development periods of usually 30 years or more (see Peiser and Chang, 1999), Korea's speedy and financially viable experiences in building new towns appear to have captured the attention of a number of developing countries currently undergoing rapid urbanization. The newspaper article illustrates how Korea is aware of the opportunity and keen to seize it, now framing urban development experience as a new competitive asset to be "exported".

There is clearly an attractive market for new city exports, especially in urbanizing Asia, where there exists much demand for urban development to accommodate rapid and massive growth of urban populations. As such, the biggest foreign market (74.1 percent) for the Korean construction companies in real estate development is found in the Asian region, with Vietnam being the biggest market for Korea's new town developments (Choi, 2015). In addition to chaebols seeking out overseas construction markets, the Korean government has increasingly begun to promote urban development as a new exportable product. The most notable and recent case is the promotion of smart cities. By integrating the country's expertise in both new town developments and the IT industry, and accompanied by the rising boom of smart city developments in Asia, the Korean government is actively seeking to export its model of smart cities. Songdo-a smart city development from scratch-is a prime example of how the government and the private sector built the new city as an exportable model to showcase to the world (Shwayri, 2013). Additionally, in 2009, the Korean government 
announced "high-tech green cities" as one of its 17 new growth drivers (Park, 2011 ), and since then, has been involved in the following projects, just to name a few: South Saad Al Abdullah New City in Kuwait, a new smart city development project in Sri Lanka and the New Kalyan Smart City Project in India.

Whether framed as a smart city or not, what Korean companies are building overseas are real estate projects that often resemble the country's urban development projects built throughout its modern urbanization. Examining the Korean company-built satellite cities in Phenom Penh, Percival and Waley (2012) noted: "Korea's rapid urbanization and development meant that Korean companies have gained considerable expertise in urban development, [particularly] regarding the technologies and construction techniques required for high-rise apartment buildings" (p. 2882). However, building new cities does not only entail physical form and construction; it should involve socioeconomic and institutional dimensions. While similar forms of urban development are being replicated in the neighboring countries in Asia, this chapter pays close attention to the political economy behind Korea's urban development history and asks whether the Korean experience in building new cities can be easily replicated elsewhere. More importantly, it also examines what should be included in an exportable model.

The remaining chapter is structured as follows. First, the chapter briefly contextualizes the Korean new towns as an overview. Then, it explains why and how new town developments became a popular type of megaproject, including the intricate regulations and institutions that were involved in the process. The key success factors that allowed often risky and expensive new town developments to become highly profitable and politically attractive policy tools in South Korea will be discussed, as well as why the megaprojects no longer promise similar kinds of success stories in urbanized Korea today. Then, the following section highlights the key attributes of the Korean new towns that should be shared with other countries and yet have been currently missing in practice and in policy discussions. In the concluding section, the chapter summarizes the Korean model of new towns and its implications for replication in other developing countries undergoing rapid urbanization in the form of knowledge sharing.

\section{Contextualizing the Korean new towns}

During the latter half of the 20th century, Korea went through two great transformations at an unprecedented speed-industrialization and urbanization. While the impressive economic development under the developmental state closely working with the chaebols have been well studied and discussed (e.g. Amsden, 1989; Kim, 1997), the urbanization story has not been given a similar level of attention. However, the state has equally been interventionist in urbanizing the country-with new town developments being the key strategy-and in fact continues to be to date for various economic or political reasons. Korea's new town developments can be largely categorized into three different policy goals: industrialization, housing supply and spatial decentralization. While the 
country has built a number of industrial new towns in the 1970s and 1980swhich later grew to become important industrial cities (e.g. Ulsan, Pohang, Gumi, Changwon, Yeosu, Onsan) (see Joo, 2019, chapter 2)-the megaprojects that have set the tone for Korea's notable new town developments have been the country's "first-generation residential new towns" built in the early 1990s, namely Bundang and Ilsan.

Bundang and Ilsan have often been mentioned and referred to in the cases of overseas urban development projects by Korean companies. For example, a newspaper article on Daewoo E\&C group's Starlake City development in Hanoi (Vietnam) is titled as “Exporting 'Bundang and Ilsan' new towns to Vietnam ... Making the best city" (Kim, 2019). It states that the Starlake new city development is where "Daewoo is transplanting Korea's urban development DNA, modelled after Bundang and Ilsan” (Kim, 2019). In fact, Daewoo showcased Bundang and Ilsan as development models when it first proposed the project to the Vietnam government in 1996 (Moon, 2012).

Bundang and Ilsan are even referenced in overseas smart city projects. The Korean government has been keen on promoting smart city developments as an "export commodity", leveraging its new town development experiences and advanced IT technologies. This strategy seems to resonate with developing countries in need of new urban development and infrastructure. For example, a newspaper article reports that when a Kuwaiti government official visited Bundang, Ilsan and Pangyo in Korea, he was persuaded by "the Korean model of new and smart city development" (Park, 2017). The Korea Land and Housing Corporation $(\mathrm{LH})$ is currently developing the master plan for South Saad Al Abdullah New City in Kuwait, which is to be three times larger than Bundang.

What explains the popularity of the Korean new towns, in particular Bundang and Ilsan? The first-generation new towns-Bundang and Ilsan-were part of Korea's Two Million Housing Construction Plan (TMHCP) launched in 1989 by then President Roh Tae-woo, who was the first president elected after the country democratized in 1987 . His signature policy was his promise to deliver two million new housing units during his five years of incumbency, at a time when the total housing stock in Korea was just over six million. Roh has been quoted to have said, "I'd like to be remembered as a 'house president'-a president who built housing" (STFSAP, 2007: 130). Both the political and economic motivations behind TMHCP and the first-generation new town developments have been analyzed in my two previous publications-a book chapter titled "New Towns: Then and Now" (2012) and a book titled Megacity Seoul: Urbanization and the Development of Modern South Korea (2019). In a nutshell, Seoul, the capital city of Korea, had its population explode from less than 2.5 million in 1960 to ten million in 1990 and was not able to keep up in terms of housing supply for its population increase-a rather familiar phenomenon that can be observed in a number of rapidly urbanizing developing countries today. Throughout the 1970s, the Korean government promoted modernized high-rise apartments in Seoul to catch up with housing demand, but failed: the housing supply rate (which is the rate of existing housing units per number of households) continued 


\section{$152 \Upsilon$ Yu-Min Joo}

to decrease and reached a mere 55 percent in 1985. Given the extreme shortage of supply and escalating housing prices, the government was concerned about a discontented urban population and poured its resources and attention to solving the chronic and severe housing shortage problem.

Bundang and Ilsan were the symbolic megaprojects at the time, and continue to be so today. They gained attention as the first massive-scale new city developments on the outskirts of Seoul, with the hopes to significantly mitigate the city's prolonged housing problem. They were connected to Seoul's subway network and were linked to each other and key cities surrounding Seoul via the Seoul Ring Expressway. There were actually five new town developments: Bundang, Ilsan, Joongdong, Pyungchon and Sanbon. The latter three, however, were more "new towns in town", as opposed to Bundang and Ilsan, which were built as new cities from scratch in open fields. With a target of housing 390,000 residents and 276,000 residents, respectively, the project development periods of Bundang and Ilsan were astonishingly short: from 1989 to 1996 (for Bundang) and 1990 to 1995 (for Ilsan) (KOLAND, 1997).

In addition to their speedy development-which makes the Korean model of new towns particularly attractive to developing countries today-Bundang and Ilsan also stand out in that they generated benefits to a number of actors involved: the main developer Korea Land Corporation (KOLAND), private construction companies, local governments and most importantly, a large number of the urban middle class, who became new homeowners in the new towns. While Bundang and Ilsan have had their share of criticisms during (and immediately after) their development, especially involving hasty construction and their becoming mere suburban bed towns for Seoul without the initially promised selfsustainability, they soon became an emblem of how fast and financially successful new towns can be developed, not only to international audiences but also to domestic policymakers and the Korean citizens at large.

I argue that, in fact, Bundang and Ilsan have set the tone for new town development projects in Korea, explaining the country's continuous reliance on their developments. After the completion of the first generation of new towns in the mid-1990s, the second-generation new town developments were launched throughout the 2000s (from 2001 to 2009). Currently, ten new towns of varying sizes (targeted populations of 88,000 to 286,000 ) have been developed (or are being developed). Unlike Bundang and Ilsan, they have much longer development periods of 11 to 20 years and have local actors participating as key actors (MOLIT, 2015, 2017). They are also located farther $(20-50 \mathrm{~km})$ away from Seoul's city center, and are linked to each other by the Capital Region Second Ring Expressway (currently under construction) that draws a much larger circle outside the Seoul Ring Expressway. Because they are located farther from Seoul than Bundang and Ilsan, self-sustainability has been accentuated even more in their planning (Lee, 2012). In addition to high-tech clusters (i.e. techno valleys) (e.g. Pangyo Techno Valley, Dongtan Techno Valley, and Gwanggyo Techno Valley), a few of the second-generation new towns have pursued the application of smart city solutions, in order to project an image of pursuing environmental 
sustainability and high-quality living environments (e.g. Dongtan, PajuUnjeong, Gwanggyo, Yangjoo, Godeok, Geomdan, and Wirye) (Lee, You and Kwon, 2015).

Following Korea's residential new town developments, Korea's housing supply rate, which was less than 70 percent in 1985, jumped to 86 percent in 1995 (MOLIT, 2005) and reached over 100 percent in 2008 (KOSIS, n.d.). Seoul's housing supply rate, which was 55.5 percent in 1985 , also nears 100 percent today. Even then, the national government recently (in late 2018) announced the third generation of new towns (Wangsook, Gyosan, Gye-yang, Chang-leung and Daejang). Their main policy goal is to lower the housing prices of Seoul rather than solving housing shortage, so these new towns are located just outside of Seoul, even closer to the city's boundary than the first-generation new towns.

At the same time the new towns were developed in the Capital Region under the rationale of lowering housing prices, another array of new city development was taking place in the rest of the country, under the policy goal of decentralization. While the Korean government has long been concerned about the unequal spatial development of the country, President Roh Moo-hyun-who came to power in 2003 from a left-leaning political party — was particularly keen on decentralizing the country's lopsided spatial development that was centered on Seoul and its surrounding Capital Region. One of his key election campaign promises was to build a new administrative capital-Sejong-located on the borderline of the North and South Chooncheong provinces. In addition, the development of ten new innovation cities was announced in 2007 (Table 9.1). The idea was to relocate public institutions from Seoul to the innovation cities, with an expectation that their relocation will trigger new vibrant economies in the hosting regions. What was expected was a synergy centered on the relocated public institutions, local universities, research centers, companies and local governments

Table 9.1 Korea's ten innovation cities

\begin{tabular}{lccl}
\hline New towns & $\begin{array}{c}\text { Planned } \\
\text { population }\end{array}$ & $\begin{array}{l}\text { \# Institutions } \\
\text { relocated }\end{array}$ & Developer \\
\hline Busan & 7,000 & 13 & Busan city \\
Daegu & 22,000 & 11 & LH \\
Gwangju & 49,000 & 16 & $\begin{array}{l}\text { LH, Gwangju city, South Cheolla } \\
\text { developer }\end{array}$ \\
Ulsan & 20,000 & 9 & LH \\
Gangwon & 31,000 & 12 & LH \& Wonju city \\
North Chooncheong & 39,000 & 11 & LH \\
North Cheolla & 29,000 & 12 & LH \& North Cheolla developer \\
North Gyeongsang & 27,000 & 12 & LH \& North Gyeongsang developer \\
South Gyeongsang & 38,000 & 11 & LH, Jinju city, \& South Gyeongsang \\
& & & developer \\
Jeju & 5,000 & 6 & LH \\
\hline
\end{tabular}

Source: MOLIT, 2018 
(MOLIT, 2018). While Sejong has an advantage of being the new administrative capital of Korea, the ten innovation cities seem to be far from achieving their ambitious goals. More than ten years have passed since the announcement of their development, yet they are considered to have failed in attracting the population from Seoul. The issue of unsold apartments and the demise of other old city centers in the region (as the new innovation cities ended up attracting populations not from Seoul but from other nearby cities in the region) have been raised as critical problems (Kim, 2018). Ironically, new city developments and shrinking cities co-exist outside the Capital Region in Korea.

Except for the industrial new towns developed in the 1970s to support Korea's heavy-chemical industrialization, the new town developments in Korea have relied heavily on the apartment complex developments. Whether in the form of innovation cities or residential new towns, their development successes have been dependent on the fast construction of apartments and how well they were sold in the real estate market-which were the key financing mechanisms of the projects, as will be elaborated in the next section. Hence, in the context of a lukewarm real estate market, the new towns would not be able to develop with much ease and speed, as can be noticed in more recent projects amid the conditions of adequate housing supply in Korea. Perhaps with more disappointing results on the horizon, Korea might eventually cease to launch new town developments and instead turn to regeneration efforts- a trend that is starting to be observed in Korea's academic and policymaking circles today. This turn of events, however, does not pertain to the international market. In fact, it is likely to even further trigger the Korean government and companies to seek out new town exports overseas, as the domestic market for new real estate megaprojects dwindles. It is thus timely to reflect on exactly how the new towns have come to be perceived as fast and profitable development projects in Korea, leading to their continuous development to date and potential interest from other rapidly urbanizing countries.

\section{Explaining Korea's fast and costless development of new towns}

What explains the development success of the two new towns, when new town developments in general tend to be very costly and risky megaprojects? Instead of imposing a huge financial burden, Bundang and Ilsan, in fact, were revenue generators. Two key factors are critical in explaining their "unlikely" profitability: the severe housing shortage at the time and various regulations and institutions that allowed swift financing of these megaprojects.

First of all, a chronic housing shortage allowed Korea to develop a number of regulations amid the escalating housing prices throughout the 1970s in the market of new apartments. Important regulations included price-ceilings on new units, a mandatory subscription account for new unit purchase eligibility, and the advanced-sale system of new units. The imposed price ceiling allowed the new unit purchasers to gain significant profits when selling their units later in the market. As apartments became coveted investments, the new unit buyers were required to own a subscription account issued by the Korea Housing Bank 
in order to prevent monopolization of the housing purchases and to increase the homeownership rate. Only one account was allowed per household, and the account holder was ranked, according to their home ownership status and history, before going through a lottery to earn the right to purchase. The state also introduced an advanced-sale system, which allowed the apartment builders to sell their units as long as they had 20 percent of construction carried out, thus allowing them to receive a prepayment of 80 percent of the total sales in advance and cover a significant amount of their costs during the development process. Under the advanced-sale system, home buyers were required to pay 20 percent when signing the contract and 60 percent during the construction, leaving only 20 percent of payment to be made when the units were actually finished (Kim and Kim, 2000). In such circumstances, it is easy to see why apartments were a financially viable product for both apartment developers as well as purchasers.

The Bundang and Ilsan developments, which involved supplying 97,500 and 69,000 new residential units, respectively, took full advantage of these existing regulations. As such, the new town projects were predominated by the highrise apartment developments. In addition, their development benefited from the Housing Site Development Promotion Act (HSDPA) enacted in 1980 under the military government of Chun Doo-hwan. The HSDPA facilitated land preparation for the apartment complex developments by allowing KOLAND to purchase fragmented land as a whole at the appraised value of its previous land uses instead of at the market price, which would have been significantly higher due to expected development. Because the sites chosen for the new towns were in the open fields, KOLAND — the public developer of Bundang and Ilsan-was able to quickly acquire the necessary land at low costs. Under the HSDPA, KOLAND was also able to sell its residential land plots to private developers and construction companies before it had even started land preparation. When purchasing the land, 40 percent of the price had to be paid when signing the contract and up to an additional 30 percent had to be paid in the subsequent four months (KOLAND, 1997). With 71 percent of sellable land being designated as residential in the new towns, KOLAND could cover most of its land preparation and infrastructure development costs upfront with its residential land sales.

To facilitate private developers' residential land purchases, the government introduced redeemable housing bonds, in addition to the already existing advanced-sale system. The redeemable housing bonds allowed the apartment developers to issue bonds up to 30 percent of the expected sales revenue (i.e. the amount equal to 50 percent of the total housing units at 60 percent of the sales price) before the construction had begun, allowing them to purchase the land with cash from KOLAND (KHI, 2006). In addition, to further entice private sector participation, in 1989, the state readjusted the price ceiling, which had remained fixed since 1983, taking into account the rising costs of labor and construction materials (Lim, 2005).

In short, through a number of regulations, an intricate financing system of new town developments was devised, lowering the burden on the key developer and construction companies involved: KOLAND could embed its significant 
costs in the sales of residential land to private companies in advance, while the private companies could shift their land acquisition and construction costs to home purchasers. With the financial costs taken care of, the massive construction could swiftly take place with ease.

Of course, this scheme worked only because there was a strong demand for new housing units in the property market, with the housing prices expected to increase significantly at the time. Lee (2009) studied who (excluding the governments) gained the most from the development of Bundang and Ilsan, and concluded that the new apartment buyers by far gained the most (more than 70 percent of the profit produced in both new town developments), followed by KOLAND (around 13-15 percent) and housing construction firms (around 1113 percent), with the landowners profiting the least under the HSDPA (around 3-4 percent).

The governments were also the major financial beneficiaries of the new town development. While KOLAND took over the bulk of the roles in the project as a public developer, governments were able to collect taxes and fees arising from the massive amount of development taking place on the previously idle land. For example, under the Restitution of Development Gains Act (enacted in 1989), there was a development charge to be paid to the national and local governments (Lim, 2005). The development charge (equal to 50 percent of the difference in land price increase after a development project) was levied and was equally divided between the national and local governments. In addition, the national government earned capital gains tax on real estate sales, and the local government earned a significant amount of local taxes during the real estate sales and purchases in the form of acquisition tax, registration tax and property tax. Therefore, Bundang and Ilsan illustrated how the new town projects could be an impressive source of revenues, turning underused land into highly profitable real estate overnight.

With almost everyone involved having gained from the representative firstgeneration new town projects of Bundang and Ilsan, their experience has shaped the perception of new towns as being an attractive policy tool and profitable development projects in the country. In other words, new towns have been welcomed by the general public and the private sector as an opportunity to make profit, in addition to being perceived as a new source of revenue for the governments. However, the whole financing system, which has allowed new towns to become profitable projects, was heavily dependent on the booming real estate market with rapidly escalating housing prices. Given the drastically changed conditions of Korea, with adequate housing supply and a plummeting birth rate, it is not too surprising that some of the recent megaprojects-especially those developed outside the Capital Region-have been more controversial.

What is more, having examined the unique financing mechanisms that have allowed Korea to build new cities quickly, one may question the replicability of such new town developments in foreign countries. The physical form and the construction technology are not the major characteristics of Korea's new towns; 
the underlying regulations and institutions that have allowed their swift development are, and these are not easily packaged and "exported" in the form of new towns.

\section{The Korean model of new town developments: what are the implications for urban development overseas?}

The Korean new towns are government-led real estate megaprojects, buttressed by a booming real estate market and intricate land development and housing market regulations. In particular, residential new towns - such as Bundang and Ilsan-exemplify physical organization, modernization, and expansion of the cities that are under the steep pressures of rapid urbanization. They are the product of the concerted efforts of the dedicated government and the private sector, in the context of the severe housing shortage problem that the once poverty-stricken country faced as it rapidly transitioned into an industrialized country. The Korean experience of new town developments thus has merit as a plausible precedent for the transitioning economies, illustrating a positive outcome that successfully catered to the needs of Seoul's urban middle class with well-planned out streetscapes and good quality housing, urban infrastructure and amenities.

The subsequent new town developments - such as Pangyo and Dongtan — that promoted a high-tech image and smart city solutions further boosted the positive appeal of the Korean new towns. With the global rise of the smart city boom on the horizon, the Korean new towns are being "repackaged" as possible development models for smart city projects. The reliance on the real estate market, however, continues for these new urban development projects that have been branded as smart cities. As a matter of fact, Korea's own smart city developments in the 2000s (referred to as ubiquitous cities or u-cities in Korea) have also mainly taken the form of new towns, or new real estate projects, where the cost of applied technology was embedded in the new housing sales price.

While these real estate projects are far from merely representing the physical forms and attributes, both the receiving countries and the Korean companies have mainly been focused on replicating the physical development aspects. For instance, Boughezoul-Algeria's first new town development on the outside of its capital city-is said to have been modeled after Bundang and Ilsan (Moon, 2012), with Korean companies in charge of construction planning, infrastructure development and urban design (Lee, 2010). A newspaper article reported that government officials of Algeria visited Korea's Bundang, Ilsan and Dongtan, and made specific requests to the Korean companies to develop in Boughezoul the same kinds of streetlights and sidewalks that they saw in the Korean new towns (Lee, 2010). To be sure, a number of Korean companies have expertise in the designing and construction of real estate megaprojects and can deliver similar products overseas. However, when considering overseas developments as part of the knowledge sharing of Korea's new town experience, it would be wise to reflect on their following key attributes that have been hitherto overlooked. 
First of all, as elaborated in the previous section, the Korean new towns are an outcome of various regulations and policies imposed on both the supply and demand sides of the housing market and land development. The HSDPA facilitated massive land acquisition for the project and allowed the quick sales of prepared land sites to the private developers; redeemable housing bonds easily attracted the participation of eager private sectors; and housing market policies such as price-ceilings and advanced-sale system led to quick sales of new units, even before the completion of their construction. The "success" of Korea's new town developments lies largely in the intricate mechanism of the financing system supported by these regulations that allowed swift completion of new towns with early housing sales and new incoming residents. Modernized urban infrastructure and form alone would not have produced the same outcomes. Hence, the conditions of a rapidly developing and urbanizing country-as Korea was in the 1970s and 1980s-do not necessarily indicate guaranteed success for new town projects that are physically modeled after the Korean new towns. Without the similar regulations and policies that were observed in Korea, it could be challenging to replicate the fast development of populated new towns.

The second attribute to highlight is that the Korean new towns mainly targeted the urban middle class as opposed to the local elites and the wealthy. As Bundang and Ilsan were injecting a large number of new housing units in a relatively short time frame to solve the chronic housing shortage problem, they were also increasing the opportunities for new homeownership to the residents that could not previously afford to own a home. For example, a study done by the Korea Research Institute for Human Settlements (KRIHS) (1993) reported that in the case of Bundang and Ilsan, the homeownership rates were 88.6 percent and 84.7 percent, respectively, and only 43.6 percent and 34.7 percent of these homeowners, respectively, were former homeowners. This indicates how a significant number of the new town residents were able to change their status from renters to homeowners, becoming the main beneficiaries of the megaprojects. As a matter of fact, studying the Korean apartments, Gelézeau (2007) commented on how the apartments were "the urban middle class production factory" (p. 143), as their escalating prices allowed new homeowners to significantly increase their assets. Bundang and Ilsan-with their 80-90 percent of total housing stock in the form of apartments - have been the exemplary case, where such mechanisms played out in full swing, allowing a large number of citizens to become new homeowners and thus helping to increase the middle class and their wealth.

Real estate market policies — such as the price ceiling on the new units and the mandatory subscription account requirement for the eligibility to purchaseagain played a key role here, helping to guarantee that more renters had the opportunity to purchase their first new homes in Bundang and Ilsan. Moreover, the new towns were never marketed as "luxury" developments. They were mainly framed to solve the social problem of ordinary citizens suffering from the housing shortage at a time when the real estate market was not adjusting quickly enough 
to the economic growth and rising demand for quality housing. Thus, they were far from representing luxurious real estate developments, which are commonly observed in other developing countries today and are often planned and developed by foreign companies. As one of the many examples of the latter, the Hanoi Real Estate Agency website describes the Starlake City developed by the Korean company Daewoo as the following:

Starlake City is aiming to become one of the most luxurious and luxurious [sic] urban areas in Asia ... Every aspect in the design of Starlake villas depicts the luxury and prestige of a refined lifestyle. ... Starlake is customized for high-class and sophisticated living.

(Hanoi Real Estate Agency, n.d.)

Considering that many of the new towns in developing countries in Asia are in the form of luxury estates or exclusive "global cities", perhaps the most important policy lesson from the Korean experience should be how its new towns sought to benefit a larger segment of the public.

Last but not least, the Korean new towns were government projects planned and led by the government and public institutions, with the private companies taking part in the construction works. In the case of Bundang and Ilsan, KRIHSa national government-funded research institute-carried out the research work required for the projects, including regional analysis, transportation research, housing research and demographic and infrastructure planning research. The Ministry of Works was responsible for the entire planning of the new town developments, and established four departments of planning, land, construction and infrastructure. The planning department engaged in the overall development planning, housing supply planning, financial planning, the planning of personnel and construction materials, the provision of housing bonds and the revising and drafting of the necessary laws and policies needed for the new town developments. The land department planned the supply of land, planned for public facilities and developed displacement and compensation policies. The construction department developed housing construction plans, technically examined and approved housing construction development proposals, intervened in the urban design process and controlled the overall standard of housing and building construction. The infrastructure department planned and executed urban infrastructure systems, such as roads, sewerage, electricity, phone services, heating systems and subways (Lee, 1996). Under these plans and guidance set by the government, the new town projects were executed by a public developer-KOLAND-as previously mentioned.

In contrast to the public sector-led new town projects in Korea, many of the foreign company-built new towns in developing countries rely on the private developers to provide all comprehensive urban infrastructure and services required for the project. The Korean company that is building Camko City on the outer edge of Phnom Penh, for example, is to develop and manage all the 
necessary infrastructure in the city, such as sewage, waste treatment, electricity, water and communications (Robertson, 2018). Examining the cases of Camko City and Grand Phnom Penh International City (built by Ciputra-an Indonesian company), Percival and Waley (2012) write:

the lack of state capacity for urban planning and appetite for city building creates the conditions in which private companies undertake urban development projects of an enormous size. In addition, the state's failure to provide adequate urban infrastructures encourages the private sector to move in.

(p. 2885)

On the one hand, the private companies could be seen as filling in the void created by the state's lack of investment in and planning of the infrastructure development; on the other hand, their primary profit motivations potentially raise some critical issues in urban development.

For example, "splintering urbanism" (Graham and Marvin, 2001) becomes quite foreseeable with the urbanization process dotted by the private companybuilt megaprojects. In her article posted in Next City, Robertson (2018) asks,

if an under-resourced government palms off the provision of infrastructure to private developers catering to the rich and influential, who will provide for the city residents, failed by the state, who cannot afford the steep price tag attached to all-inclusive property?

Indeed, the article also mentions how in Camko City, one notices many cars with license plates of high government officials and military elites of Cambodia. These projects are furthermore isolated when there is a lack of overarching planning connecting them to the rest of the larger urban network. Unlike the Korean new towns, both Camko City and Grand Phnom Penh International City failed to connect to the major transport system to the center of Phnom Penh or to each other (Paling, 2012).

Another important point to underscore is that new town projects are more likely than not to end up targeting the high-end market when relying on the profit-driven private sector for infrastructure development. The private developer would need to embed the development costs to the housing and commercial property sales, resulting in sales price increases. Consider this point in Korea's recent promotion of "exporting" smart cities. Without a doubt, the ICT and smart technologies can be delivered by Korean companies, nicely packaged in a new city development project. However, the development costs will be reflected in the property sales price unless they are heavily subsidized by the receiving government, which is not plausible in the context of a developing country. What is likely to result is a high-tech and high-end luxury real estate project, with a looming question of who will benefit, and how, from the urban development. Therefore, the latest boom of launching new smart city projects in developing countries becomes rather worrisome, especially when they are not backed by 
careful planning and development strategies of their governments in pursuing smart city policies.

Having examined the key attributes of the Korean new towns juxtaposed against the realities of new town developments taking place overseas, it seems fair to say that the Korean companies are far from replicating the true nature of the Korean model of new towns. They are at most scratching the surface by mimicking the physical form and urban infrastructure. While it may be difficult to expect the private sector to take social and public-value interests over profit, more should be expected when it comes to new town development as a knowledge-sharing program involving governments. Rather than solely seeking to find new markets overseas, the government-initiated knowledge sharing activities should also embody more public-centric goals—although it may be challenging-for the overall benefit of the receiving country's citizens at large and to enhance their government's capacity-building efforts. To do so, it is critical that both sides-the receiving countries and the Korean counterpart-have a more accurate grasp of what the Korean model of new towns is (beyond their physical façade), why they were "successful", and thus exactly what kinds of knowledge should be shared. To contribute to this effort, this chapter hopes to bring some of the important attributes that had been "hidden" beneath the physical form into the discussion of the Korean model of new town developments.

\section{Conclusion}

Korea-once a foreign aid recipient country now transformed to a donor country-is in a position to share what has worked in its development experience, as its experience can resonate more closely with developing countries than those of the early industrializers in the West. Korea particularly prides itself in its new town developments, which have accompanied the country's modern economic development and urbanization. Leveraging its decades of experience in new town developments, and especially with its export-driven economy now facing steep competition and pressure with China's rapid rise in the global economy, Korea is keen to export its urban development know-how to its neighboring developing countries that are currently undergoing rapid urbanization. Indeed, Bundang and Ilsan new towns effectively responded to the increased need for modernized housing and urban landscapes brought by Korea's economic transition at the time. They certainly have the potential to attract developing countries facing similar challenges today. However, it is imperative to know what the Korean model of new town development actually represents in knowledge sharing. The types of new towns being developed by Korean companies overseas, as well as Korea's recent promotion of "exporting” smart city projects, unfortunately indicate a somewhat lacking understanding of what should be "exported" or shared to other countries when it comes to these ambitious megaprojects. So far, what the developing countries have been "importing" seem to be mostly construction technology and the urban form. 


\section{$162 \Upsilon$ Yu-Min Joo}

The key attributes of the Korean model of new town developments are not in their physical attributes but in their development policies, involving an array of regulations and institutions that not only allowed swift development of the new towns, but also benefited governments, private companies and the urban middle class at large. These urban megaprojects-led and carefully planned by the government and public institutions-were backed by the public sector's numerous efforts in planning, policy making and infrastructure development that were required. The capable state and its role thus need to be underscored when explaining the Korean model of new towns. In addition to the public role and effective policies, what should also be emphasized is how the new towns sought to house and benefit the urban middle class at large, as opposed to targeting a handful of elites and expatriates in the form of luxury estates. In short, I suggest that the public roles and values inherent in the Korean new towns-which have been missing thus far in the discussions-demand particular attention in the knowledge sharing of these important megaprojects.

\section{References}

Amsden, A. H. (1989). Asia's Next Giant: South Korea and Late Industrialization. Oxford: Oxford University Press.

Choi, J. S. (2015). "Current State of Overseas New City Development and Promotion Strategy," Real Estate Focus 89, pp. 39-50.

Gelézeau, V. (2007). The Republic of Apartments: South Korean Apartment Complexes as Seen by a French Geographer. Seoul: Humanitas.

Graham, S. and S. Marvin (2001). Splintering Urbanism: Networked Infrastructures, Technological Mobilities. London: Routledge. .

Hanoi real estate agency (n.d.) "Starlake City Hanoi: Villas \& Apartments". [Online] Available at: https://hanoirealestate.com.vn/apartment-building-in-tay-ho-dist/ starlake-hanoi.44.html. [Accessed November 1, 2019].

Hwang, J. S. (2011). "The Korean Wave of Apartments: It is Now an Era of New City Exports," Donga Ilbo, November 11. Available at: http://news.donga.com/home/3/ all/20111110/41773509/2. [Accessed November 1, 2019].

Joo, Y. M. (2012). "New Town Developments in Korea: Then and Now," in G. Del Cerro (ed.), Urban Megaprojects: A Worldwide View. London: Emerald Group Publishing, pp. 3-25.

Joo, Y. M. (2019). Megacity Seoul: Urbanization and the Development of Modern South Korea. Oxford and New York: Routledge.

KHI (Korea Housing Institute). (2006). Research on Redeemable Housing Bonds. Seoul: Housing Industry Research Center.

Kim, C. H. and K. H. Kim (2000). "The Political Economy of Korean Government Policies on Real Estate," Urban Studies 37(7), pp. 1157-1169.

Kim, D. I. (2018). "Shrinking Cities Outside the Capital Region: Increasing Number of Both Apartment Units and Empty Houses," Sisa-In. June 21. Available at: https:// news.v.daum.net/v/20180621110804845. [Accessed November 1, 2019].

Kim, E. M. (1997). Big Business, Strong State: Collusion and Conflict in South Korean Development, 1960-1990. Albany: State University of New York Press. 
Kim, H. J. (2019). "[Searching for the New Korean Wave of Construction] Exporting Bundang and Ilsan New Towns to Vietnam ... Making the Best City," Asia Economy, January 9. Available at: www.asiae.co.kr/article/2019010810163324097. [Accessed November 1, 2019].

KOLAND (Korea Land Corporation) (1997). Bundang New Town Development. Seoul: KOLAND.

KRIHS (Korea Research Institute for Human Settlement) (1993). A Research on Residential Pattern Following New Town Developments in the Capital Region. Seoul: KRIHS.

Lee, B. H. (2012). 2011 Modularization of Korea's Development Experience: Korean Version of New Town Development. Seoul: Korea Research Institute for Human Settlements.

Lee, E. A. (2010). "MK Real Estate. 'Having been to the first export of "the Korean new city", " in Algeria, Boughezoul. September 16. Available at: estate.mk.co.kr/news2011/ view.php? $\mathrm{sc}=90000001 \&$ year $=2010 \&$ no $=505773$. [Accessed November 1, 2019].

Lee, K. I. (1996). "Development Structure of Bundang New Town," in National Architecture Research Association (eds.), 18C New Town and 20C New Town. Seoul: Balun (in Korean).

Lee, K. J. (2009). "A Study on the Betterment Distribution of Residential Development: Focused on the lst New Towns," Master's Thesis. Seoul: Konkuk University.

Lee, S. K., H. Y. You and H. S. Kwon (2015). Korea's Pursuit for Sustainable Cities through New Town Development: Implications for LAC, Inter-American Development Bank: Discussion Paper. Seoul: Korea Research Institute for Human Settlements, pp. $1-44$.

Lim, S. H. (2005). A Half Century of Housing Policy. Seoul: Gimundang.

MOLIT (2015). "Introduction to the First-Generation New Towns," MOLIT, July 28, 2018. Available at: www.molit.go.kr/USR/policyData/m_34681/dtl?id=523. [Accessed September, 3, 2020].

MOLIT (2017). "Introduction to the Construction of the Second-Generation Capital Region New Towns," MOLIT, July 28, 2018. Available at: www.molit.go.kr/USR/ policyData/m_34681/dtl?id=524. [Accessed September 3, 2020].

MOLIT (2018). "The Current Development Status of Innovation Cities," MOLIT, Available at: http://innocity.molit.go.kr/module/board/bbs_download.jsp?sidx=26 \&stype $=1 \& b i d x=349 \& i d x=3744$. [Accessed November 1, 2019].

Moon, S. H. (2012). "Global Development Boom of the "Korean Model of New Towns' ... Increased Demand for the Construction Companies," Jose-Ilbo, December 20. Available at: www.joseilbo.com/news/htmls/2012/12/20121220165353.html. [Accessed November 1, 2019].

Paling, W. (2012). "Planning a Future for Phnom Penh: Mega Projects, Aid Dependence and Disjointed Governance," Urban Studies 49(13), pp. 2889-2912.

Park, S. M. (2017). "New Town That Is Three Times Larger Than Bundang in Dessert ... Putting Wings on the 'K-Smart city' export", Dong-A Ilbo 4, April, Available at: www.donga.com/news/article/all/20170404/83675114/1. [Accessed November 1, 2019].

Park, Y. G. (2011). “Current Trends and Policy Tasks for 'city export'”, SERI Economy Focus 356, pp. 1-15.

Peiser, R. and A. Chang (1999). "Is it Possible to Build Financially Successful New Towns? The Milton Keynes Experience,” Urban Studies 36(10), pp. 1679-1703.

Percival, T. and P. Waley (2012). "Articulating Intra-Asian Urbanism: The Production of Satellite Cities in Phnom Penh," Urban Studies 49(13), pp. 2873-2888. 


\section{$164 \Upsilon$ Yu-Min Joo}

Robertson, H. (2018). “The Pristine Exclusivity of Cambodia's 'Imported Cities', Next City. February 12. Available at: https://nextcity.org/features/view/the-pristineexclusivity-of-cambodias-imported-cities. [Accessed November 1, 2019].

Shwayri, S. T. (2013). "A Model Korean Ubiquitous Eco-City? The Politics of Making Songdo," Journal of Urban Technology 20(1), pp. 39-55.

STFSAP (Special Task Force for State Affairs Press) (2007) Forty Years of Real Estate in Korea. Seoul: Hans Media. 


\title{
10 Housing policy and urban redevelopment in contemporary Korea
}

\author{
Seong-Kyu Ha
}

\section{Introduction}

Since the 1960s, South Korea (hereafter Korea) has achieved remarkable success in reducing poverty. However, behind this picture of growth and progress, Korean urban housing has experienced serious problems. Though Korea has become economically wealthy compared to the past, it has proven difficult to narrow the housing gap between income brackets. There is a huge disparity between housing need and supply. Importantly, housing conditions are polarizing between the well-off and the poor.

Since the late 1970s, large-scale substandard settlements have decreased substantially due to rapid economic growth and mass demolition through housing renewal and urban redevelopment projects. Housing renewal projects in lowincome residential areas were not distributing housing according to individual and collective needs. Millions of poor people have been evicted from urban redevelopment areas in the past five decades. Understanding the impacts of housing and urban renewal policies has become an increasingly complex task. In the Korean context, housing and urban renewal projects have both advantages and disadvantages; there are those who benefit and those who lose. And while housing renewal brings about the physical improvement of the city, it further exacerbates the housing conditions of the poor. Housing renewal needs to be approached from the perspective of housing welfare and urban redevelopment policy (Gibson and Langstaff, 1982; Kim and Ha, 1998; Smith and Williams, 2013).

Urban and housing renewal has changed the spatial patterns of low-income residential areas in many cities. Since the 1970s, the urban and housing renewal project, which was undertaken as part of a housing supply expansion policy, has forced low-income residents from the city center to the outskirts of the city. From the 1990s, most of the substandard settlements in the Capital Region began to be located in satellite cities and suburbs where housing and land prices were relatively low. The housing and urban redevelopment project has played a decisive role in urban sprawl and gentrification in Seoul.

The purpose of this chapter is twofold: first, to explore the characteristics and impacts of low-income housing policy and housing renewal projects; second, to 
discuss the implications of Korean low-income housing policies on development cooperation for developing countries.

\section{Urban growth and the low-income housing situation}

\section{Urban growth}

The housing situation in Korea is closely related to the effects of urbanization as well as demographic factors. During the 1960s and 1970s, high rates of population growth and internal migration to urban areas, accompanied by limited housing supply, typically resulted in the overcrowding of existing dwellings and in squatting. The extent of such problems may have varied from one urban area to another, but the results were fundamentally the same: high densities, sanitation problems, unsafe living conditions and insecurity of tenure, among others (Mills and Song, 1979; UN Habitat, 1996, UN Habitat, 2015).

The 1960s and 1970s were characterized by very rapid urbanization. It is surprising that the largest increase was over the two decades from 1960 to 1980. In 1960 , the proportion of the urban population relative to the total population was 28 percent; by 1980, this had rapidly increased to 60 percent.

In the pattern of Korea's urbanization, the following points are of major importance. First, the population in urban areas has increased greatly both in absolute and relative terms. Since 1955, the disparity between rural and urban population growth has intensified ( $\mathrm{Ha}, 1999)$.

Second, the urbanization of Korea is characterized by its rapidity and spatial concentration in a few large urban centers (Kim, 1999). Furthermore, the growth rate of large cities has been relatively higher than smaller ones in most periods, causing their share of the total population to increase.

Third, since the late 1980s, an interesting fact about the spatial distribution of the population has emerged: the extent of the spillover growth of small cities and counties adjacent to the larger cities. With the exception of those surrounding the largest cities, almost all counties have undergone population loss.

Fourth, the rapid increase of population in the fringe areas of Seoul and its satellite cities has led to a new phenomenon: the metropolitanization of Seoul. The Seoul Metropolitan Region (SMR) includes the city of Seoul itself, Gyeonggi Province and Incheon city. The total area of the SMR is approximately 11,726 $\mathrm{km}^{2}$; it accounts for about 11 percent of the country's total area but contains about half of the total population (49.6 percent in 2017). Population growth has led to economic concentration. Almost half of the nation's employees were to be found in the SMR in 2017; moreover, in the same period, over 68 percent of all bank deposits were made in the SMR.

Fifth, after the 1990s, the proportion of the urban population size of Korea's cities has had a tendency to change. The percentage of cities with a population between 500,000 and 1 million has been steadily increasing, but the percentage of cities with a population less than 500,000 has been decreasing. It is interesting to note that, even though the population of the Capital Region as 
a whole has been increasing, the population of the capital city, Seoul, has been decreasing, from $10,612,577$ in 1990 to $9,820,171$ in 2005 . This suggests that the transformation of the urbanization structure is making some of the core city populations either relocate to neighboring cities or else contribute to their own cities' suburbanization processes (UN Habitat, 2015).

The population growth rate in Korea has been decreasing substantially since 2000. Growth accelerated between 1955 and 1966 to 29.2 million or an annual average of 2.8 percent. However, it declined significantly during the period 1966 to 1985 to an annual average of 1.7 percent. Thereafter, the average annual growth rate came to less than 1 percent, similar to the low growth rates found in most industrialized countries. The average number of babies born per woman of reproductive age may have been as low as 0.96 in 2018 , falling below 1.0 for the first time in history, according to a study commissioned by the Chosun Ilbo newspaper. Fertility rates falling well below the replacement level of 1.0 births per female have triggered national alarm, with gloomy predictions of an aging society unable to grow or support its elderly. Recent Korean governments have prioritized the issue on their agendas, promising to enact social reforms to encourage women to have children.

The most important factor to consider is the number of households that require housing and their characteristics. It is interesting to note that between 1960 and 1980, while the proportionate share of small- and medium-sized households increased, that of large-sized households decreased. Surprisingly, the proportion of single-person households has increased since 1960, when only 2.3 percent were single-person households, compared to 27.2 percent in 2015. Households with only one member have drawn attention as the proportion of the nation's single-person households has increased significantly since the 2000s. Behind the rising trend of single-person households are social changes, such as an increase in marriage age, an increase in divorce rates and an aging population.

The concentration of populations and changes in household composition in urban areas have caused serious housing problems. In the following sections, we will look closely at the housing situation and attempt to explain how housing development has evolved over time.

\section{The low-income bousing situation}

Housing does not simply mean the physical reality of housing. A residence includes a person's residential activity space and the life that takes place in it. Human beings protect and maintain family life through residential activities, child education and rest and community roles. The housing issues in urban Korea can be summed up in a few key words: "housing disparity" and "polarization". In this chapter, housing disparity and polarization have a similar meaning. They both refer to the widening gap in housing quality levels between income brackets, communities, tenure types and housing types (apartments and detached houses). Despite Korea's remarkable economic development, many people still 
do not have adequate housing. The Habitat Agenda defines adequate shelter in the following manner:

Adequate shelter means more than a roof over one's head. It also means adequate privacy; adequate space; physical accessibility; adequate security; security of tenure; structural stability and durability; adequate lighting, heating and ventilation; adequate basic infrastructure, such as water-supply, sanitation and waste-management facilities; suitable environmental quality and health-related factors; and adequate and accessible location with regard to work and basic facilities: all of which should be available at an affordable cost.

(UNCHS, 1997, paragraph 60)

In Korea, those who cannot live in adequate housing belong to the housing need group. "Housing need" refers to the number of housing units necessitated by population growth and growth in the number of households. Essentially, housing need is a number, derived from population and household size projections, that makes no allowance for affordability (Robinson, 1979; Holmans, 1995; Department for Communities and Local Government, 2010). This is not to be confused with housing demand, which is defined as the relationship between "the price of housing and the quantity and quality of housing for which people are able and willing to pay" (Shucksmith, 2002: 61).

By meeting housing needs, people are empowered to live in satisfactory housing even if they cannot afford it (Tighe and Mueller, 2013: 87). Most housing problems are essentially a problem of a lack of effective demand for decent housing (Oxley, 2000: 2). Therefore, it is important that the correct housing is built to meet the needs of the population. This will play a significant role in improving the economy.

Korea's population has continued to grow and this has created a larger number of households that need more housing. To understand this, we need to look at the historical background of Korea's population growth and housing shortages. The number of Koreans returning from overseas after liberation (1945) was 1.379 million from Japan, 415,000 from Manchuria and elsewhere, and 740,000 from North Korea. Most settled mainly in urban areas, particularly in Seoul. Meanwhile, damaged housing in Seoul accounted for 30\% of the total housing inventory due to the Korean War (1950-1953). Most of these returning Koreans could not find work and lived mainly in substandard settlements (Kim and Ha, 1998: 29).

The housing problem for low-income urban households can be understood from three perspectives. First, there has been a shortage of affordable and public rental houses for low-income people since the 1960s. The government has adopted a policy of expanding the supply of public housing; however, this supply has been insufficient to meet the housing needs of low-income households. Second, the residential environment of low-income urban households has been poor and there have been many low-income households that have fallen short of the housing minimum standard. For example, in the 1980s, about 20-30 percent 
of Seoul's population lived in so-called squatter settlements. Residents of these slums occupied mainly public land illegally. They constantly suffered under the threat of demolition, and public housing for them was very limited (Brandt, 1982). Third, the Korean economy has grown remarkably over the past half century; as a result of this economic growth, the quality of housing has begun to improve and the housing shortage has begun to gradually ease. However, in terms of housing quality and affordability, relative poverty has begun to increase: the housing conditions of the poor have deteriorated, whereas the housing conditions of the middle class and above have greatly improved. In other words, a new housing issue has emerged in which the rich get richer and the poor get poorer. Housing and urban redevelopment have played a large part in this housing disparity between income brackets.

"Housing stock" is the total of all housing units in Korea. It may be described in terms of the location of housing units, the quantity and quality of housing units, and how well these housing units meet people's needs. The number of housing units has fallen below the number of households, and the increase in households has outpaced that of available dwellings. The housing shortage has been particularly acute in urban areas because of the accelerating urbanization ratio, which drastically increased from 41.2 percent to 78.9 percent from 1970 to 1995 .

Table 10.1 shows changes in the housing supply ratio and other housing condition indicators from 1980 to 2015 . By almost any standard, the overall quality of housing has increased substantially since the 1980s. The sustained economic growth since the 1970s has been accompanied by improved housing quality (Kim and Park, 2016). The average size of housing has increased substantially, and the proportion of houses with hot water and flush toilets has also increased steadily. The average number of persons per room has decreased from 2.1 to 1.3 , and per capita floor space increased from $10.1 \mathrm{~m}^{2}$ in 1980 to $26.9 \mathrm{~m}^{2}$ in 2015 .

The population that moved to the city caused severe housing shortages and housing prices soared beyond the reach of ordinary citizens. The poor built squatter settlements comprised mostly of unlicensed housing. All housing materials were of low quality and development was completely unplanned. The proportion of the population living in slums and squatter settlements on hillsides

Table 10.1 Indicators of housing conditions (1980-2015)

\begin{tabular}{lrrrrr}
\hline & 1980 & 1990 & 2000 & 2010 & 2015 \\
\hline Dwellings per 1,000 inhabitants & \multicolumn{1}{c}{142} & \multicolumn{1}{c}{170} & \multicolumn{1}{c}{249} & \multicolumn{1}{c}{302} & \multicolumn{1}{c}{383} \\
Housing supply ratio & 71.2 & 72.4 & 96.2 & 100.5 & 102.3 \\
Number of persons per room & 2.1 & 1.5 & 0.9 & 0.7 & 1.3 \\
Floor space per person $\left(\mathrm{m}^{2}\right)$ & 10.1 & 14.3 & 20.2 & 25.0 & 26.9 \\
Floor space per household $\left(\mathrm{m}^{2}\right)$ & 45.8 & 51.0 & 63.1 & 67.4 & 68.4 \\
Dwellings with flush toilets (\%) & 18.4 & 51.3 & 86.9 & 97.0 & 97.3 \\
Dwelling with hot baths/showers (\%) & 9.9 & 34.1 & 87.4 & 96.9 & 99.8 \\
\hline
\end{tabular}


varied from city to city, but figures of 20-30 percent were common in the 1960s and 1970s. Substandard housing has been most prevalent in Seoul.

Since the early 1980s, poor housing conditions, such as physical deterioration, lack of facilities and security and overcrowding, have been associated with two kinds of new settlement: Binilhaus and Beoljip. A Binilhaus (vinyl house) is constructed of thin wooden board layers with vinyl covers on the outside. Beoljip refers to various kinds of basement or attic residences in low-income housing areas. Most Binilhaus occupants are poor tenants who have been forcibly evicted from housing and urban renewal areas. They do not have enough money to rent even a room in the low-income residential areas. Binilhaus squatters have simply settled in vacant hillside areas or public open spaces without any rights of land ownership or building permits. Most Beoljip residents are low-income, unskilled laborers who are employed at nearby manufacturing companies; as such, this kind of housing is mostly located near industrial zones or factory districts.

To improve housing conditions, the Korean government introduced housing minimum standards in 2000. These minimum standards consisted of four sections: the bedroom standard, the housing facilities standard, the floor space standard, and the environmental standard. The total number of households under the housing minimum standards was 1,030,000 in 2016, which accounted for 5.4 percent of total households. The housing conditions of residents in rental houses were worse than those of house owners. The dwelling conditions of renters were poor with respect to floor space and number of bedrooms. The minimum standards were upgraded in 2011 by increasing the minimum floor area as well as requiring a modern kitchen, toilet and bath/shower. Even though the housing minimum standards are important criteria to judge citizens' housing conditions, there are no specific regulations for improving poor housing conditions. In order to achieve greater, more balanced social development in Korean society, the government must first establish medium- and long-term policies for households that do not meet the minimum housing standards. Given the financial limitations, it would be better to take a phased approach. Priority should be given to vulnerable groups, such as those with a disability living below the minimum standards. The fundamental goal of future housing policies is to enable everyone to enjoy housing rights.

\section{Housing renewal projects}

The Korean government has made efforts to alleviate substandard housing. Various approaches during the 1960s and 1970s can be placed into four categories: (1) the clearance program for squatter settlements, (2) the legalization and self-help development program, (3) the relocation program and (4) the citizen apartment and high-density public housing program.

The clearance program was to clear squatter settlements from public land designated as parks, public areas around railroads and green zones. In practice, clearance programs were a police action where detection of newly built units led to physical removal and tenant eviction. The squatter settlements were bulldozed 
by wrecking crews to prevent their being reoccupied. The sweeping demolition of substandard settlements caused many problems.

The government recognized that it is difficult to solve the problem solely through the demolition method. Therefore, the government implemented a site and service program based on self-help efforts. The legalization and self-help development program led to the active participation of residents in the spirit of Saemaul Undong. However, the program was not successful. As such, the government implemented programs to relocate many of these poverty-stricken residents in substandard settlements to peripheral areas. This program, known as the relocation program in Seoul, relocated about 40,000 households to new sites between 1966 and 1972 .

On August 10, 1971, tens of thousands of residents of Gwangju complex in Gyeonggi Province (currently in Seongnam city) took over the city in protest of the government's irrational urban and housing policies and intense administration. Gwangju complex is a satellite city planned as a part of slum dweller maintenance and the removal of squatters in Seoul. According to the plan, the city was to create a large-scale complex in Gwangju and relocate 101,325 households to 21,372 households by the time of the incident. However, the Gwangju large-scale relocation project had the following problems from the beginning.

First, land speculation was rampant. This was caused by the city of Seoul's desire to secure the funds for the development of the complex, which were insufficient, through development profits. Second, the residents had no means of livelihood, as most within the relocation area were urban poor. These poor migrants were required to make daily commutes to and from Seoul to search for jobs. However, public transportation was inconvenient and transportation costs were a financial burden for them. In response, these poor migrants illegally resold their pre-emptive rights and settled again in other areas of Seoul without permission.

Since the early 1980s, Korea's urban and housing redevelopment projects have brought about three broad categories of change: (1) urban redevelopment, (2) "new towns" and (3) housing reconstruction. In 1983, a new redevelopment project was developed, known as the "Joint Redevelopment Program" (JRP), which was supposed to take on the spirit of a homeowner (landowner)construction company partnership. To work on the redevelopment sites, a redevelopment association was created to work with homeowners to acquire the required two-thirds vote for approval.

In the JRP district, the predominant housing type was apartment accommodation. In the 1980s, the majority of redevelopment apartments had three rooms, with an average size of $118 \mathrm{~m}^{2}$. As such, the average floor space per household in the redeveloped area was higher than that of Seoul city as a whole. The survey evidence demonstrates that the average income in JRP housing was much higher than that of the typical urban wage earner's household. They certainly belonged to Seoul's middle- or upper-income classes (Ha, 2001). This placed the former squatters in an impossible position, placing an excessive burden on each household and making it difficult to benefit from redevelopment projects. 
Most residents (including homeowners) had no permanent job and were forced to rely on daily employment opportunities. If a squatter couldn't afford a new unit, they could sell their priority rights to brokers at a small profit. Tenants also faced difficulties. Because the initial housing redevelopment project included no countermeasures against the tenants, these tenants protested against forced demolition and demanded an alternative housing stabilization program. To forcibly evict resisting tenants, the association and the construction company often hired eviction agencies.

In its initial form, JRP included serious human rights violations (Murphy, 1990; Murphy and Pimple, 1995; Ha and Kim, 2017). Poor tenants were forced to leave the communities they had lived in for a long time. Renters, who were usually 60 percent of the population in the redevelopment areas, were excluded by law from sharing any benefits. The JRP destroyed these poor communities. There were many speculators who were willing to pay high prices for houses in JRP areas that were very likely to be designated for redevelopment. Therefore, many of the homeowners were not residents and had only invested to gain a large profit through redevelopment.

Interestingly enough, housing renewal has changed the spatial pattern of Seoul's low-income residential areas. Since the 1960s, the housing and urban redevelopment projects have forced low-income residents from the inner city to the middle ring areas and, finally, to the outskirts of the city. In the 1990s, most of the substandard settlements in the SMR were located in satellite cities and suburban areas where the housing and land prices were relatively cheap. The housing renewal and urban redevelopment project has played a decisive role in creating urban sprawl and gentrification in Seoul.

As of 2015, total housing built through the JRP was 295,224 units nationwide, with Seoul supplying 282,047 units or 95.5 percent of the total. In sum, 744,994 total housing units will be supplied nationwide, including what is currently in progress and what is on standby.

A new type of urban renewal project emerged in the 2000s. The "new town in town" scheme was first introduced in 2002 by former Seoul mayor Lee Myungbak when Seoul's metropolitan government changed their urban renewal policy and renamed it the "new town" project. This project was designed to transform alienated residential areas into quality residential environments by expanding infrastructure and implementing various urban functions. Existing redevelopment projects in residential areas were mainly carried out as small, privately led individual projects. As such, it was difficult to link the redevelopment project to the surrounding adjacent areas. In addition, it was difficult to improve the residential environment as there were limitations to the installation of urban infrastructure such as roads, parks and school sites. As a result, there has been a growing need to solve the problem of connecting infrastructure to adjacent areas that occurred in privately led individual projects and to establish a framework to secure infrastructure for redevelopment and its surrounding areas. Accordingly, the Seoul Metropolitan Government proposed a New Town Special Law to the central government in August 2005. In December of the same year, the Special 
Act on the Promotion of Urban Regeneration was enacted to lay the legal foundation for new urban projects.

Because existing redevelopment projects placed priority on generating development profits, most low-income native inhabitants were unable to resettle and their communities collapsed. Therefore, the need to reduce the burden on residents and enhance the resettlement rate of the original residents was increased. Compared to existing redevelopment projects, the new town project had the following distinguishing characteristics: (1) the designation of a widearea (living area) unit, (2) an increase in the role of the public sector (a leading role in infrastructure planning and support), (3) an emphasis on the importance of connecting adjacent areas when carrying out renewal projects, (4) the combination of various project methods and (5) the encouragement of resident participation.

Most of the slum dwellings that had existed in Korean cities have now been demolished and redeveloped due to various low-income housing policy programs and residential redevelopment policies implemented since the 1980s. From the point of view of many developing countries, Korea can be seen as a very successful case because slums have been eradicated in a short period of time. However, this success is grounded in the unique socioeconomic and political conditions of Korea. It is not easy to generalize this particular Korean situation to all developing countries.

Despite various criticisms, Korea's establishment of essential community facilities and infrastructure in substandard settlements has important policy implications. For example, institutionalization through housing renewal projects is considered to be an important policy for the provision of essential community service facilities such as roads, water and sewage, electricity and schools. Housing and urban redevelopment policy may be a useful model for developing countries in terms of infrastructure supply through development profits, whereby the government uses the profits generated from the residential redevelopment projects to supply and improve community facilities.

\section{Impacts of housing renewal and urban redevelopment}

\section{Impacts of housing renewal}

The housing renewal programs impacted urban development in numerous ways. First, they moved the poor from the urban center to suburban areas. This was because most of the early housing renewal programs were projects to demolish substandard dwellings located in urban centers or inner urban area of the city. Poor people in housing renewal zones were driven out of the city's suburbs to temporary settlements regardless of their wishes. They were forced to move. Housing renewal projects in urban areas began to weaken the residential functions of urban centers, filling them instead with service sectors. This phenomenon was exemplified by the fact that poor residents in the Cheonggyecheon redevelopment area in Seoul were forced to move to Gwangju complex. 


\section{Seong-Kyn Ha}

Second, the housing renewal projects in Seoul and other cities removed the existing single-family houses and maintained the pattern of building only highrise apartments. There were several reasons to build high-rise apartments uniformly through the housing renewal and urban redevelopment project. The first reason was to accommodate as many people as possible per unit area due to expensive land prices. The second reason was that developers and landowners intended to maximize their profits. Koreans prefer apartments rather than singlefamily homes or townhouses. This is because of the perception that apartments are safe and comfortable compared to other types of housing. Moreover, it is also important to note that apartments have a higher market value than other types of housing. As a result, the housing renewal project has transformed the apartment into the principal housing type of the city. The apartment has become the universal housing type for Koreans.

Apartments are the most popular housing option among Koreans. As urban development and cost of living have skyrocketed over the years, most Koreans have taken up apartments as their residential option of choice. Nearly all complexes have facilities nearby such as a supermarket, district office, post office, schools and easy access to public transportation. Basic utilities such as water, gas and heating are well established. Table 10.2 illustrates the number of households in Korea in 2017 by housing type. The majority of the population live in high-rise apartment blocks with more than five stories. The household number of this housing type reached around 9.4 million. The city with the highest proportion of apartments in Korea was Sejong City with 69,300 apartments in total.

Third, from the perspective of urban development and management, the gap between the redeveloped districts and the rest of the residential areas has widened. The redeveloped district has been equipped with modern facilities; however, in the case of traditional residential areas where renewal has not been carried out, residents experience many inconveniences when community facilities are poor.

Fourth, with the emergence of JRPs in Seoul, an interesting trend has occurred in substandard residential areas. This is very similar to the gentrification observed in cities in North America and Western Europe. It is possible to identify some characteristics of gentrification (Shin, 2017; Shin and Kim, 2015; Ha, 2004; Freeman, 2005). In Korea, gentrification is a phenomenon in which outsiders and money flow in with the development of underdeveloped areas near

Table 10.2 Current status of housing stock by type in 2017 (in 1,000s)

\begin{tabular}{llllll}
\hline $\begin{array}{l}\text { Housing } \\
\text { types }\end{array}$ & $\begin{array}{l}\text { High-rise } \\
\text { apartment }\end{array}$ & $\begin{array}{l}\text { Detached house } \\
\text { (stand-alone } \\
\text { house) }\end{array}$ & $\begin{array}{l}\text { Multiplex } \\
\text { housing/raw } \\
\text { house }\end{array}$ & $\begin{array}{l}\text { House in } \\
\text { abusiness } \\
\text { building }\end{array}$ & Total \\
\hline & $\begin{array}{l}3,963 \\
(60.375\end{array}$ & $\begin{array}{l}2,576 \\
(15.0)\end{array}$ & $\begin{array}{l}209 \\
(1.2)\end{array}$ & $\begin{array}{l}17,123 \\
(100.0)\end{array}$ \\
\hline
\end{tabular}

Source: National Statistical Office, Population and Housing Census www.index.go.kr/potal/stts/ idxMain/selectPoSttsIdxSearch.do?idx_cd=1242 
the city center and where the original residents are forced out due to higher rents. Residential areas and high-end shops are created by the influx of upper-class residents into the underdeveloped old town where middle and lower classes live. Some neighborhoods in Seoul-for example, Bongcheon-dong, Sillim-dong and Shingil-dong - have many old, backward residential areas. Most of the houses in this area are single-family homes, and most of these are illegal and unauthorized. Therefore, many big cities, such as Seoul, built numerous apartments to accommodate a large number of people in a small area. Most of these apartments have large flats, and most of them are built as high-end brand apartments, making it difficult for the original people to resettle. It has been easy for private capital (large construction companies) to flow into urban renewal projects, and the influence of large companies and capital investment has been getting stronger (Yoon, 1994).

Displacement imposes substantial hardships on certain classes, particularly lower-income tenant households and the elderly. The poor tenants evicted through housing renewal projects are hit particularly hard, finding the least satisfactory alternative housing units and neighborhoods and facing the highest proportional shelter-cost increases. The influx of middle- and upper-class groups into working-class neighborhoods brings high rents and relatively high housing prices.

Fifth, one of the important housing renewal policy issues is how the state empowers and cooperates with non-government organizations (NGOs), community-based organizations (CBOs), communities and the private sector. Gentrification in Seoul was led by the state via housing renewal and urban regeneration projects. In Korea, NGOs and CBOs were intended to fill a gap in government services. They mobilize resources, materials and volunteers to create localized community programs. Some NGOs and religious organizations have organized anti-eviction campaigns and lobbied for governmental housing and urban renewal policies favorable to low-income families, poor tenants and socially vulnerable classes. The cooperation between governments and NGOs should be emphasized. By promoting a true social movement, urban and housing renewal will emerge as a people-centered development.

Sixth, the housing shortage emerged as an important political issue, which Korean politicians took up, making the improvement of housing conditions a key campaign pledge. There were two major shortcuts to resolving the housing crisis. Most politicians believed that the first thing they had to do was build a large number of housing units. The second thing they believed they had to do was increase housing supply through housing renewal in low-income housing areas. In 1988 especially, the new government vowed to supply 2 million homes and pushed housing construction as a national policy. The most appealing political slogan at the time was housing mass construction and supply to solve the housing crisis. In this context, the government set up a plan to build five new towns around Seoul to solve the housing shortage. Seoul's expansion stimulated the development of adjacent areas. The first new cities (Bundang, Ilsan, Pyeongchon, Sanbon and Jungdong) were developed in the 1990s and the second new cities (Seongnam, Pangyo, Hwaseong, Gimpo, Paju, etc.) in 
the 2000s. With the development of the public transportation network, the SMR expanded even more. Over the years, Seoul's administrative districts have expanded significantly, especially since the 1990s, when new towns were developed. Seoul's spatial expansion was aided especially by the development of subways and transportation networks.

Built in the 1990s, Bundang was one of Seoul's first planned suburbs. It was built as a response to a severe housing shortage and has generally been considered a success. Seoul's suburbs are one of many examples of how higher density suburban communities can be designed by creating larger subdivisions. For example, the suburbs of Korea are higher in density than in many Western countries, including the United States. There are as many as 61,500 people living within one square kilometer, or 157,450 people per square mile, in Bundang. That is almost 13 times as many people as New York's Levittown of 4,900 people per square kilometer, or 12,500 people per square mile (Reurbanist, September 24, 2012). A highly efficient subway was built between Seoul and the new towns; bus routes were also developed. Most of the new towns in Korea were apartmentoriented developments designed to provide large amounts of housing, and the proportion of detached or row houses was relatively low.

Let us summarize the advantages and disadvantages of housing renewal and urban development projects, including JRP. Since the housing renewal project was implemented in the 1990s, there has been a change in the level of residential areas in the city. Most large cities in Korea have focused on building new residential areas or new towns in the suburbs of the city. As a result, there is a large gap between the traditional residential areas inside the city and the newly developed suburban residential areas. In other words, the old downtown areas have poor residential environments and the new suburban development areas enjoy relatively good residential environments.

Therefore, the government has recently placed greater policy importance on urban regeneration projects than on suburban development. One of the main tasks of the current government is the New Deal for Urban Regeneration, which will inject a total of 50 trillion won over the next five years, including two trillion won for the budget, five trillion won for housing city funds and three trillion won in public enterprise projects every year for 500 underdeveloped regions across the country. More than half of the project sites will be promoted to smaller areas with 1,000 households or less. "New Deal" refers to a project that aims to improve an urban environment by maintaining its existing appearance, unlike the reconstruction and redevelopment projects that completely demolished existing housing.

The urban renewal project is designed to reinvigorate the city not only physically and environmentally but also economically, industrially, socially and culturally to overcome the urban hollowing out caused by the new town-oriented expansion in suburban areas and to improve the city's sluggish economy. Depending on regional characteristics, two types of urban economic infrastructure and neighborhood regeneration will be implemented. "Neighborhood-type regeneration" refers to policies that improve living conditions in underdeveloped neighborhoods and preserve regional characteristics, as in existing redevelopment projects. 
In addition, the New Deal for Urban Regeneration will create jobs in existing urban renewal projects. In particular, it is characterized by rebuilding cities with national goals, such as historical and cultural restoration, landscape and architecture, youth housing, eco-friendly renewable energy businesses and youth start-ups. Unlike the current urban readjustment projects-such as reconstruction and redevelopment, which completely demolishes neighborhoods - the New Deal project is designed to improve the urban environment by maintaining the existing shape of roads and houses or by installing additional cultural service spaces and small amenities.

Most housing and urban redevelopment projects, including the JRP, have taken the form of demolishing old houses and building new apartments. However, the new approach can boast some very successful redevelopment cases. One example is Gamcheon Culture Village in Busan. The Gamcheon Culture Village Project is an urban regeneration project that sought a paradigm shift from redevelopment and reconstruction to "preservation and revitalization". To maximize its chances of success, a governance system was created involving residents, artists and the government, departing from previous government-led systems. The income generated by the project was reinvested into village development businesses, ensuring the sustainable development of the community. In 2008, when urban renewal involving major construction swept through many of the other underdeveloped areas of Busan, a more non-destructive approach was suggested by artists and academics for Gamcheon, which had seen its population dwindling and houses quickly emptying out. The Gamcheon Culture Village has become one of the most famous cultural brands in Busan and beyond, setting a new standard for urban regeneration initiatives. In 2015, Gamcheon was visited by more than $1,400,000$ people, transforming it from a poor, marginalized area into a dynamic cultural village full of life.

\section{Policy transfer and implications}

It is necessary to discuss the implications of Korea's housing policy for developing countries. With regard to low-income housing policy and housing renewal, what are the benefits and risks of cross-border housing policy transfer? It is perhaps surprising that the world suffers from many common problems and that we can potentially learn from each other's experiences. In order to make the housing policy transfer, we may need to conduct a comparative analysis. Comparative analysis and research may have the following benefits (Doling, 1997; Oxley, 1991; Angel, 2000): It may broaden researchers' horizons and bring new experiences; it may teach us lessons drawn from the successes and failures of others; it may allow us to examine our housing system to determine the interrelationships between variables, thereby enabling us to develop new approaches; and it may also allow us to gather new ideas to increase policy innovation.

Difficulties and uncertainties arise when policy makers try to apply policy tools and programs from other countries based on comparative analyses. It can be cumbersome to try to use measurement devices developed in other countries because, 
due to cultural differences, they can contain different cultural meanings, especially differences in housing norms. In a broad sense, as cross-country learning and cross-modification increase, convergence on efficient, equitable and sustainable housing policies seems to rise. In practice, however, this convergence has involved many mistakes, inversions and failures.

I would like to point out four key dimensions differentiating Korean housing policy from that of other developing countries. First is the structure of the housing supply system. Understanding the nature of the construction industry and the diversity of promotions is essential to understanding the diversity of production among countries. The second key point is that ideological factors are crucial to understanding long-term approaches to housing in a country. It is also necessary to consider what characteristics individual governments have. For example, Korea maintained an authoritarian government system for a long time. Third, there is a tendency for countries to arrive at different policy choices and strategies depending on the size of the economy and its stage of economic development. Finally, all countries have their own social and cultural systems, in particular, housing norms. Korean society, for example, has a unique housing tenure system (Ha, 2003).

Korea's housing policy program experience over the past 50 years can teach the following lessons to developing countries. The first is the benefit of overall economic growth. Since the 1960s, Korea's economic growth has been remarkable, allowing for an expansion in housing supply and improved housing quality. The Korean economy has essentially adopted a mixed economic system with a strong role for government. State-led economic development has produced rapid economic development, transforming underdeveloped countries into developed countries; this has sometimes been referred to as the miracle on the Han River. Second, public institutions related to housing have played a large role-for example, the Korea Land and Housing Corporation. Without public institutions for housing and land development, it would have been difficult to expand the supply of public housing. Third is the role of the authoritarian government in Korea. In order to supply a large number of houses in a short period of time, the central government needs to be dedicated and highly efficient. For example, the plan for the supply of 2 million housing units and the building of five new towns in the metropolitan area was the product of the central government-led role of the authoritarian state. There were, of course, many criticisms made of the authoritarian government's undemocratic policy making and enforcement.

Taken together, Korea's experience shows that the most important factor in achieving low-income housing stability is that the national economy needs to grow and develop to some extent. This is because housing welfare programs can be realized only insofar as national income and household incomes increase to a certain level. This must also be accompanied by a strong, dedicated government. At the same time, various housing programs for the stabilization of national housing need to be carried out. Of course, Korea's experience is not applicable to all developing countries. Nonetheless, Korea's years of trial and error can provide useful data for policy development in many developing countries. 


\section{Conclusions}

The housing situation in Korea is closely bound up with the effects of urbanization as well as with demographic factors. Today, the urban housing problem in Korea is in a new phase. The most noteworthy is the rapid increase in singleperson households and the increase in the number of elderly households. Most single-person and elderly households suffer from housing instability and economic difficulties. In addition, Korean society is facing various socioeconomic problems due to low fertility. There are also measures to boost the birth rate, but they are not very effective. The fertility rate and housing stability are very closely related. According to a survey of newlyweds' fertility rates, households that have stabilized their homes have a higher birthrate than those that have not.

The Korean government has been heavily intervening in the housing market to stabilize housing prices and control speculation (Chiu and Ha, 2018). In addition, Korea's housing policy focuses on expanding housing supply to help ease housing shortages. The chronic housing shortage in urban areas has been addressed to some extent through housing renewal projects, but there have also been a variety of side effects. The issue of housing insecurity and inequality has arisen most acutely in the case of urban renewal policy, particularly JRPs in lowincome residential areas (Shin, 2017; Shin and Kim, 2015; Ha, 2004).

Residential areas that are predominantly occupied by low-income households, such as manual workers and poor tenants, have become occupied by middle- and high-income households through the housing renewal and urban redevelopment projects. This process-known as gentrification-occurs in poor communities. In the past, housing renewal has sometimes been implemented as a physical or technical exercise in home improvement; now, however, these aspects are seen as just one dimension of an approach that aims to develop local communities and improve neighborhoods. By widening the scope of renewal activity, we may hope to achieve more comprehensive and holistic improvements (Turkington and Watson, 2015).

In planning for housing programs in Korea and other countries, a comprehensive approach is needed, encompassing both micro and macro methods. This comprehensive approach will involve four major elements. First, it will be necessary to design a housing program in response to variables in urban housing situations; it will also be necessary to develop a customized housing program for residential situations. Second, the allocation of resources (between the various housing and productive processes) will need to be based on clear definitions of housing conditions and objectives. Third, housing programs will need to be incorporated into the national planning process: every time a government has been replaced, the existing housing program has been changed. A consistent policy is needed. Fourth, democratic procedures will need to become increasingly important. A participatory mechanism should be established in which different social needs can be addressed and where the needs of citizens can be reflected in the decision-making process of housing and urban renewal projects. In all countries, the concept of governance is becoming important in order to accommodate conflicts of interest, mobilize resources and manage cities successfully, 


\section{References}

Angel, S. (2000). Housing Policy Matters: A Global Analysis. Oxford: Oxford University Press.

Brandt, V. S. R. (1982). "Upward Bound: A Look at Korea's Migrant Squatters," Korea Culture 2(4), pp. 16-27.

Chiu, R. L. H. and S.-K Ha, eds. (2018). Housing Policy, Wellbeing and Social Development in Asia. London: Routledge.

Department for Communities and Local Government. (2010). Communities and Local Government's Departmental Annual Report 2009, and the Performance of the Department in 2008-09. London: House of Commons.

Doling, J. (1997). Comparative Housing Policy, Houndmills: Macmillan Press.

Economic Planning Board, Korea Statistical Yearbook, various years.

Freeman, L. (2005). "Displacement or Succession? Residential Mobility in Gentrifying Neighborhoods," Urban Affairs Review 40(4), pp. 463-491.

Gibson, M. S. and M. J. Langstaff (1982). An Introduction to Urban Renewal. London: Hutchinson.

Ha, S.-K. (1999). "Urban Growth and Housing Development in Korea: A Critical Overview," Korea Journal 39(3), pp. 63-94.

Ha, S.-K. (2001). "Substandard Settlements and Joint Redevelopment Projects in Seoul," Habitat International 25, pp. 385-397.

Ha, S.-K. (2003). "The Urban Poor, Rental Accommodations, and Housing Policy in Korea," Cities 19(3), pp. 195-203.

Ha, S.-K. (2004). "Housing Renewal and Neighborhood Change as a Gentrification Process in Seoul," Cities 21(5), pp. 381-389.

Ha, S.-K. and K. H. Kim (2017). "In-Movers' Housing Choice and Gentrification in Seoul," Journal of Urban and Regional Analysis IX(2), pp. 159-172.

Holmans. A. (1995). Housing Demand and Need 1991-2011, York: Joseph Rowntree Foundation.

Kim, H. K. and S. K. Ha (1998). Redevelopment of Squatter Settlements. Seoul: Nanam (in Korean).

Kim, K. H. and M. Park (2016). "Housing Policy in the Republic of Korea," Asian Development Bank Institute Working Paper (570), Manila: ADB.

Kim, S. H. and S. C. Park (September 7, 2018). " '0.9 Shock” This Year ... Low Birth Rate Maginot Line Collapses.” Available at: http://news.chosun.com/site/data/html_dir/ 2018/09/03/2018090300158.html.

Kim, Y. W. (1999). "Industrialization and Urbanization in Korea," Korea Journal 39(33), pp. 35-62.

Korean Statistical Information Service (KOSIS). Available at: http://kosis.kr/eng/ search/searchList.do, various years.

Mills, E. and B. N. Song (1979). Urbanization and Urban Problems. Cambridge: Harvard University Press.

Ministry of Land, Infrastructure and Transportation, http://stat.molit.go.kr, various years. Murphy, D. (1990). A Decent Place to Live. Bangkok: ACHR.

Murphy, D. and M. Pimple (1995). Eviction Watch Asia. Bangkok: ACHR.

National Statistical Office (2017). Population and Housing Census. Seoul: NSO.

Oxley, M. (1991). "The Aims and Methods of Comparative Housing Research," Scandinavian Housing \& Planning Research 8, pp. 67-77.

Oxley, M. (2000). Future of Social Housing: Learning from Europe, London: Institute for Public Policy Research. 
Robinson, R. (1979). Housing Economics and Public Policy, London: Macmillan.

Shin, H. B. (2017). "Urban Movements and the Genealogy of Urban Rights Discourses: The Case of Urban Protesters Against Redevelopment and Displacement in Seoul, South Korea," Annals of the American Association of Geographers 108(2), pp. 356-369.

Shin, H. B. and S. H. Kim (2015). "The Developmental State, Speculative Urbanisation and the Politics of Displacement in Gentrifying Seoul," Urban Studies. doi: 10.1177/ 0042098014565745

Shucksmith, M. (2002). House Building in Britain's Countryside. London: Routledge.

Smith, N. and Williams, P. (eds) (2013). Gentrification of the City, London: Routledge.

Tighe, R. J. and E. J. Mueller (2013). The Affordable Housing Reader. London: Routledge.

Turkington, R. and C. Watson (2015). Renewing Europe's Housing. Bristol: Policy Press.

UN Habitat (1996). An Urbanizing World: Global Report on Human Settlements. Oxford: Oxford University Press.

UN Habitat (1997). The Habitat Agenda Goals and Principles, Commitments and the Global Plan of Action, UN Habitat. Available at: https://www.un.org/en/events/ pastevents/pdfs/habitat_agenda.pdf.

UN Habitat (2012). Global Housing Strategy, First Report: Regional Reviews and Global Assessment of the Global Strategy for Shelter to the Year 2000. Nairobi: UNCHS.

UN Habitat (2015). "Urbanization and Development: Emerging Futures," World Cities Report 2016. Nairobi: UN Habitat.

Yoon, I. S. (1994). Housing in a Newly Industrialized Economy: The Case of South Korea. London: Avebury. 


\title{
11 Land development schemes in South Korea
}

\author{
Background, structure and outcome
}

\author{
Seohwan Lim
}

\section{Introduction}

A UN report predicted that the world urban population would increase from 4.22 billion in 2018 to 5.17 billion in 2030 and then to 6.68 billion in 2050 . More than 80 percent of the increase is expected to be in developing countries (United Nations, 2019a). A major consequence of urbanization is the expansion of urban land area. Urban land is the locus of shelter, industry and urban public services and infrastructure. It is the starting point of all urban development (Payne, Piaskowy and Kuritz, 2014). Developing countries thus need a significant area of adequately serviced urban land to cope with the rapid urban growth, which may provide an important opportunity for the social and economic progress of these countries, as cities are drivers of innovation. A shortage of adequately serviced land most likely results in unplanned urban expansion, often with squatter settlements of poor quality and a loss of the abovementioned opportunity. Actually, the number of people living in slums increased from 807 million to 883 million between 2000 and 2014, mostly in developing countries (United Nations, 2019b).

Land development in this chapter means the conversion of greenfield or underused land into serviced urban land for public purposes. Land development systems can be categorized according to land acquisition methods, which are the foremost part of the land development process. There is a broad array of traditions of public acquisition of privately owned land. They include voluntary bargain and sale; public acquisition of leasehold interests and options; acquisition through barter or exchange; public-private ventures including land readjustment, charitable organizations, development plans, turnkey projects and land sharing; acquisition through confiscation and nationalization; and acquisition through gift or dedication (Kitay, 1985).

The South Korean legal system for land is based on a complete private landownership. Land development for public purposes is largely divided into two categories in terms of land acquisition, Land Readjustment (LR) and Public Purchase and Development (PPD). LR is a development method in which land is acquired not through purchase but through replotting. PPD is a different method in which land is purchased normally by compulsion. LR played an important role in the 
planned expansion of urban areas until the 1970s. Towards the late 1970s, however, the government's plans for mass housing construction rather than urban plans began to lead land development. Since the 1980s, PPD has replaced LR as a dominant land development method, as LR became less effective in providing cheap land for mass housing construction. With these two development methods, however, South Korea could meet fast growing demand for urban land during the 1960 and 1970s, a period of rapid urbanization. As PPD also began to expose limitations in providing cheap land for housing and planned urban development, the government introduced a new land development system that combines LR and PPD in 2000. This chapter examines how and under what circumstances the development systems have worked and discusses some points at issue, as well as a few factors for success, which can be shared with other rapidly growing and urbanizing countries.

\section{Rapidly growing demand for land in the early stage of national development}

South Korea began to experience rapid urbanization in the 1950s. The urban population grew particularly rapidly from the 1950 s to the 1980 s due to increasing rural-to-urban migration, as shown in Table 11.1. In Seoul, the capital city, the population was 1.7 million in 1950 just before the Korean War (1950-1953). This dropped to 0.65 million in 1951 due to the war and then rebounded to 1 million in 1953 when the Korean War ended, and then increased to 2.4 million in 1960 (SI, 2010).

Accordingly, the demand for urban land grew rapidly. In the 1950s, however, South Korea had not yet recovered from the aftermath of the sudden collapse of Japanese colonial rule (1945) and the devastating Korean War. The country heavily relied on foreign aid for its survival (Hamilton 1986), and the government lacked the financial capabilities to provide adequately serviced land to accommodate the growing urban population. Legal systems for urban planning and land development were also inadequate to cope with the rapid urbanization until the early 1960s. The systems were until then based on the outdated Chosun (Korea) Town Planning Ordinance that was set up in 1934 by the Japanese colonial authorities primarily to implement LR projects in areas that were strategically important for colonial rule.

Without the proper provision of serviced land for housing, the rapidly growing urban population resulted in the growth of squatter settlements in big cities

Table 11.1 Urbanization rate in South Korea, 1950-2010

\begin{tabular}{lccccccc}
\hline Year & 1950 & 1960 & 1970 & 1980 & 1990 & 2000 & 2010 \\
\hline Rate* $^{*}$ & 23.5 & 39.1 & 50.1 & 68.7 & 79.6 & 88.3 & 90.9 \\
\hline
\end{tabular}

Source: (MOLIT 2019a)

Note: * Percentage of urban population to total population of the nation. 
including Seoul, where many of the urban migrants occupied land on hillsides and riversides and built shanty towns. Urban migration accounted for 65 percent of the population growth in Seoul between 1960 and 1966. It increased to 82 percent between 1966 and 1970. There were 53,000 squatter houses in Seoul, accounting for 20 percent of the total housing stock of the city at the end of 1961. The figures rose to 187,500 and 32 percent, respectively, in 1970 (KNHC, 1992; SI, 1999). It was early in the 1960s, soon after a group of military elites seized power, when the government established urban planning and development systems to cope with the rapid urban growth.

During the 1950s, the political economy of South Korea was characterized by mercantile capitalism and political cronyism. Dominant businesses profited from preferential access to controlled supplies of the over-valued foreign exchange and limited domestic credits. This system came to a deadlock in the late 1950s and brought about political strains (Hamilton, 1986; Mason et al., 1980), and the First Republic (1948-1960) was overturned by a student uprising (known as the April 19 Revolution) against the corrupt practices in politics and economics in 1960. A military coup led by an army general, Park Jung-hee, followed in 1961, overthrowing the short-lived democratic Second Republic that succeeded the first one. The military junta advocated the eradication of corruption, the elimination of poverty and the establishment of a self-reliant economy as a revolution pledge. They regarded businesses based on the "mercantile practices" of the 1950s as ruinous to the nation and launched industrialization as a keystone of national development (Das, 1992). In order to promote industrialization, they assumed control of the commercial banks by confiscating the stocks owned by big enterprises accused of corruption in 1961 (FKI, 1987). The military regime thus could control a good 90 percent of the assets of organized finance (Hamilton, 1986). It enforced a strong directed credit policy, a policy to concentrate financial resources into industrial development (Renaud, 1989). The directed credit policy played a factor in the formation and expansion of private loan markets, which provided substantial funds for speculative investment in property development. In politics, the military regime carried out extensive constitutional and institutional reform to establish a highly centralized government system. A strong presidential system replaced the previous parliamentary one, and local autonomy system was suspended. The labor movement was placed under strict control (Kim, 1980). This political and economic reformation established a statism that dominated the entire process of national development up until at least the 1980s. It is in this vein that the government has since led land development.

The government then completely re-established the laws and regulations concerning land development. Newly enacted in 1962 was the Urban Planning Act (currently the National Land Planning and Utilization Act), which prescribed various methods of urban land development. They include the Land Compartmentalization and Rearrangement Project, the Preparation Project for a Group of Housing Sites and the Preparation Project for a Group of Industrial Sites. Most land development for urban and industrial use in the 1960s was carried out through these projects. The Land Compartmentalization and 
Rearrangement Project is the legal name of the LR project. The others are all PPD projects. The Preparation Project for a Group of Housing Sites and the Preparation Project for a Group of Industrial Sites were in principle to be carried out by local governments or public development corporations within the scope of urban planning. Land could be purchased by compulsion. Later on, the Land Compartmentalization and Rearrangement Project Act was re-established separately from the Urban Planning Act in 1966. This was followed by the Housing Construction Promotion Act in 1971 and the Industrial Site Development Promotion Act in 1973. The latter two were laws on PPD to promote land development for housing and industry. ${ }^{1}$ After all, land development systems are basically divided into two categories: LR and PPD.

At least until the 1970s, land development was mostly carried out through LR for the expansion of urban areas or readjustment of damaged urban districts under the direction of urban planning. Towards the late 1970s, however, when the government needed to secure large tracts of cheap land for its mass housing construction plan, LR began to lose its popularity with the government. Land provision for housing rather than for planned urban development became the primary purpose of land development, and PPD began to replace LR as the dominant land development method. The discussion in this chapter begins with how LR worked and what problems made it unsuitable for the government's housing construction plan in the late 1970s.

\section{Land readjustment}

LR has been a major means of urban land development in South Korea since it was introduced in the 1930s by the Japanese colonial authorities. It is to be executed within urban planning zones determined by urban planning. In LR, the developer, normally the city government, subdivides and develops land with the landowners' agreement. The land is divided into three parts: compensation land, public land and returned land or replot. The compensation land is retained by the developer in order to finance the development costs through sales. The public land is kept by the developer to facilitate public services such as roads, schools, parks and so on. The remaining parcel is returned to the landowners according to a predetermined schedule. The financing of the infrastructure costs and the project's overall profitability depends on the gains from sales of the compensation land. Here, the price for the compensation land depends on the infrastructure costs. If the costs are high, the city government must increase the price, or it has to increase the amount of compensation land. This means the reduction of returned land, intensifying tension with landowners. Therefore, higher land prices after development is essential for the financing of development. Landowners agree to LR projects expecting high prices of returned land, and it is in the interests of all parties that the prices of developed land remain high.

LR was found to be most effective during the 1960s and 1970s, when the government suffered from a lack of financial resources and had to rely on landowners to give up a part of their land for implementing planned urban development and 
Table 11.2 Land development by LR (project completion, $\mathrm{km}^{2}$ )

\begin{tabular}{llrlrrl}
\hline Period & $\sim 1940 s$ & $1950 s$ & $1960 s$ & $1970 s$ & $1980 s$ & $1990 s$ \\
\hline Nationwide* $^{*}$ & n.a. & 13.8 & 39.0 & 175.5 & 190.6 & 52.8 \\
Seoul** & 17.0 & 1.2 & 63.7 & 43.6 & 14.5 & - \\
\hline
\end{tabular}

Notes: * KRIHS (2008), p. 35 Table 4-1.

** SMG (2017), p. 52

infrastructure provision (UN Habitat, 2019). As shown in the Table 11.2, LR provided more than $420 \mathrm{~km}^{2}$ of urban land nationally and $140 \mathrm{~km}^{2}$ in Seoul by the 1980s. In Seoul, LR projects accounted for 40 percent of the built-up area (SMG, 2017). A few reasons can be named for such an achievement. The first is government-led development. The rapidly growing urban population as seen in Table 11.1 drove the need to expand urban areas with the necessary public services and infrastructure. As the government lacked resources to purchase land for urban development during the 1960s and 1970s, it resorted to LR, which was conceived as an efficient way of securing urban land and infrastructure with little financial burden on the government. LR was to be implemented primarily by landowners or their association. But in a case where the landowners did not apply for authorization within a definite period of time or the contents of the application were found improper, the Minister of Land, Infrastructure and Transport (MOLIT) could order the competent local government or a public development corporation to execute the project. Furthermore, most of the land for LR was farmland in the outskirts of built-up urban areas, and landowners there were mostly small land holders and lacked expertise and funds. ${ }^{2}$ Most of all, it was a period when statism dominated most of the political and economic fields, as previously mentioned. Consequently, local governments carried out most of the large-scale LR projects. In Seoul, for example, the city government carried out 96 percent of LR projects (SMG, 2017).

The second was the increase in real estate investment. Since the 1960s, the economy grew rapidly. The nation's annual real GDP growth rate increased on average from 4 percent before the 1960s to 8.4 percent in the $1960 \mathrm{~s}$; it increased to 9.0 percent in the 1970 s and to 9.7 percent in the $1980 \mathrm{~s}$, and henceforth slowed down to 6.5 percent in the 1990s and to a mere 4 percent in the $2000 \mathrm{~s}$ (NGII, 2017). Household income was also increasing. Per capita GDP was USD 93.8 in 1961, and rose to USD 279 in 1970 and to USD 1,704 in 1980 (World Bank national accounts data). The directed credit policy mentioned earlier brought about a dualistic financial system, an institutional financing system based on low interest rates and a very large private loan market where nominal shortterm interest rates varied between three to six times the banking rates during the 1960s and the 1970s (Renaud, 1989). In a situation in which consumer credit, mortgage finance and a social security system for households were almost non-existent, households' savings were attracted to the private loan market. Real estate also became good objects for investment as a hedge against inflation during the high inflation period of 1970 s. $^{3}$ The household savings accumulated into 
speculative funds circulating in private loan markets and real estate markets have become major financial sources for land and housing development. Expansionary monetary policy in the 1970 s also contributed to the property boom of the 1970s as represented in fluctuating land prices in Figure 11.2. In the mid-1970s, the economy was emerging from recession. Industries driven by export began to prosper. Export grew rapidly and revenues from the booming construction market in the Middle East increased sharply. The government increased the money supply to support the development of the heavy and chemical industries. All these helped increase liquidity and brought about inflation, and resulted in increasing speculative investment in land development (Lim, 1994).

As the 1970s progressed, the purpose of land development policy shifted from the planned expansion of urban land to the provision of cheap land for mass housing construction. Since the 1960s, the housing shortage problem was getting worse. As shown in Figure 11.1, the housing supply ratio, the ratio of the number of housing units to the number of households in the country, was 84.2 percent in 1960. The ratio fell to 78.2 percent in 1970 and to 71.2 percent in 1980. It hit the lowest level, below 70 percent, in the mid-1980s. In 1972, the government drew up a mass housing construction plan. It was a time when the Third Republic faced political and economic difficulties. The economy slumped for a while with a falling economic growth rate, increasing trade deficit and foreign debt, and faltering enterprises. North-South Korea relations were on the brink of war. The chronic protests and demonstrations for democratic constitutional reform by human rights organizations, democratic movements and students constantly troubled the government. Labor disputes and the urban poor's struggle for shelter emerged as one of the central elements of social unrest. In October 1972, President Park staged a self-coup (known as the October Restoration). He suspended the existing constitution and replaced it with an even more

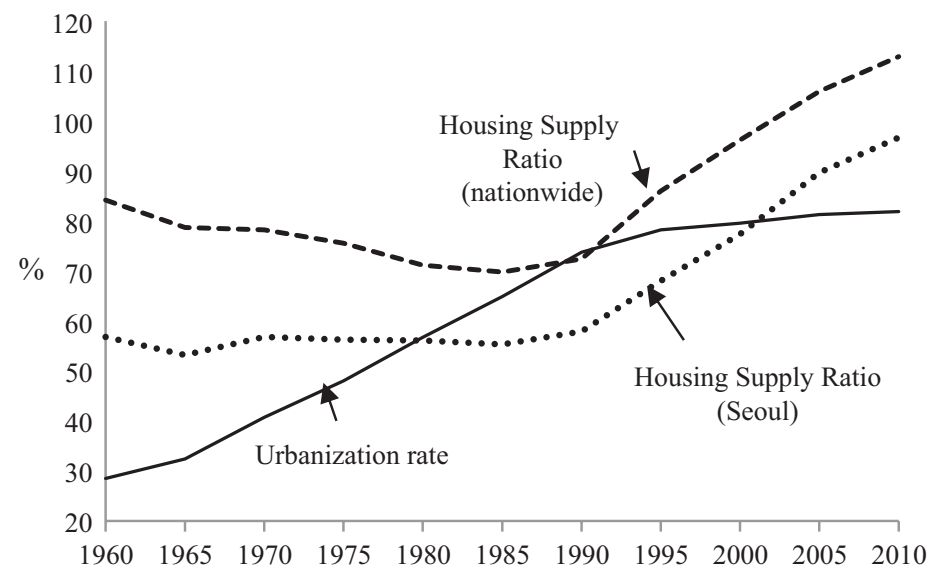

Figure 11.1 Housing Supply Ratio and Urbanization Rate. 


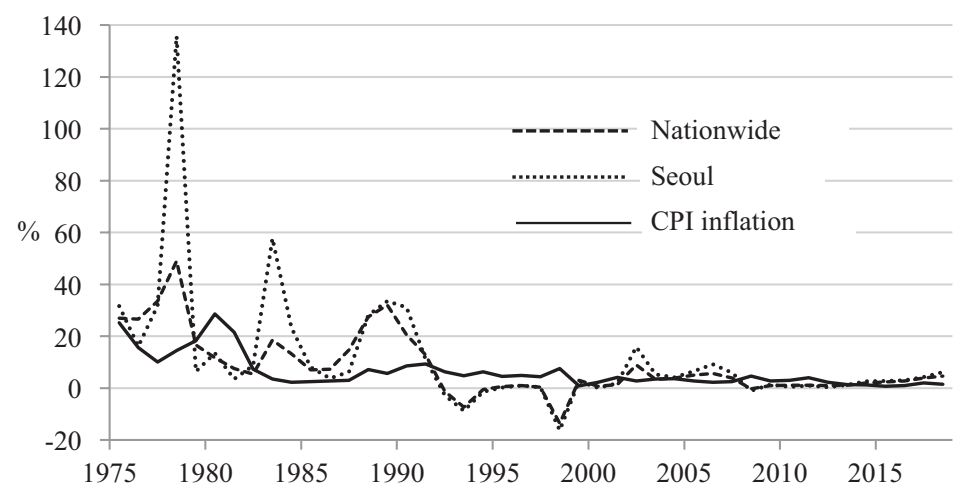

Figure 11.2 Land Price Fluctuation Rate (\% on year-on-year basis).

authoritarian one that vested the president with full powers to rule the country by emergency decree. The Fourth Republic was thus established (Lim, 1994).

Recognizing the aggravating housing shortage as a source of popular discontent in a situation of political crisis, the government established a plan to build 2.5 million housing units within 10 years, which required large tracts of cheap land for housing. Here, LR exposed its limitations in supporting the plan. First of all, LR was ineffective in securing cheap land for housing. The property boom of the 1970s helped promote LR projects as previously mentioned, but at the same time, involved a land speculation boom and the consequent swift rises in land price. The most noticeable example was seen in the Youngdong Land Readjustment Project in Seoul. ${ }^{4}$ Youngdong refers to an area commonly called Gangnam, which literally means the south of the Han River that cuts across Seoul. In 1960, approximately 2.4 million people lived in an area of $270 \mathrm{~km}^{2}$ north of the Han River in Seoul. By the early 1970s, the population more than doubled in the same area. The government was concerned about the concentration of a huge population and the country's important political and economic functions being just a few minutes away from air raids by the communist North. The Youngdong Land Readjustment Project, the largest ever LR project in South Korea, was part of the government policy to decentralize the population and urban functions into the Gangnam area. The project started in 1968 and was completed in 1985, and successfully turned $27 \mathrm{~km}^{2}$ of greenfield land into new urban serviced land (Seoul Solution, 2015). In the project, however, rampant land speculation and the consequent rapidly rising land prices generated huge public controversies. Land prices rose by five to more than 10 times between the mid-1970s and early 1980s. ${ }^{5}$ Irregular practices of land speculation prevailed. They included the buying and selling of land among speculative investors themselves, artificially inflating prices, unregistered transactions to evade transfer taxes, monopoly pricing and so on. These activities brought about public criticism, and landowners were under increasing criticism for their excessive share of development gains. 
According to data from the Korea Land Development Corporation (currently the Land and Housing Corporation), 84.1 percent of the increased land value due to development fell to landowners in the early 1980s. This was in contrast to the new Public Purchase and Development system in which, according to the same data, landowners benefited little from development (Cho, 1990). Local governments too were often accused of taking too much development gains, and inflating land prices.

Second, LR was particularly ineffective in providing land in large plots for apartment complexes, which the government was promoting to build. Apartment housing was regarded as a housing type that could save both construction costs and land costs by applying standardized and mechanized building techniques in higher densities. Opportunely, the demand for apartments was rapidly increasing due to the growing popularity of apartments among middle- and higher-income households and the consequent influx of speculative money into new apartment markets. A major reason for the increasing popularity concerned the conveniences and comforts of apartment housing. Apartments were equipped with modern facilities such as central heating systems, hot water supply, flush toilets and so on. In large apartment estates, there were shopping centers, schools, security guards and playgrounds within walking distance. Furthermore, apartments were easily tradable in the housing market as they were more or less standardized in shape, size and price (Lim, 1994). By this time, most people lived in traditional detached houses that accounted for 96 percent of total housing stock as of 1970 (KNHC, 1996). The traditional detached houses mostly lacked these conveniences and amenities. For the government, the construction of apartment complexes had an additional advantage: it provided sites for public services such as police substations, kindergartens, post offices, children's playgrounds, neighborhood parks and even schools without government spending.

In order to promote the construction of apartment complexes, the government introduced the apartment zone system in 1976. In an apartment zone, no other housing than apartments could be built. However, in LR projects, land was replotted normally into relatively small plots as landowners were mostly small land holders. This made it difficult for housing developers to secure land for large apartment complexes. In December 1975, the Land Compartmentalization and Rearrangement Act was revised to ensure the compensation land assembled in large-sized plots for apartment construction. Furthermore, the government instructed local governments to allocate all the compensation land for apartment construction. However, most local governments preferred to sell land in small plots to individuals mostly through public sale (auction) because of its profitability. In February 1978, the Minister of MOLIT instructed local governments to allocate all compensation land in the LRP projects for apartment development except those for public use. Later, the government went so far as to order local governments of large cities to develop land for housing through methods other than LR to avoid a sharp rise in land prices (Lim, 1994).

Third, the conflict between public developers, normally city governments, and landowners over the replotting plan often delayed land development. The most 
challenging was the reduction of replotting due to rising project costs and the increasing demand for public land often intensifying tension between the project executors, normally local governments and landowners. In Seoul, the average rate of land reduction rose from 31.6 percent in the 1960s to 55.0 percent in the 1980 s. This resulted in frequent delays to projects. LR projects required five to six years or even 10 to 20 years owing to the complexity of the replotting process (LHI, 2019: chapter 3). This is compared to later PPD projects, which created new towns with areas of 10 to $20 \mathrm{~km}^{2}$ within five to six years. All these made LR unsuitable for land development for mass housing construction.

The government, going through another period of political upheaval between 1979 and 1980, had to introduce a more powerful PPD system. In 1979, the authoritarian ruler, President Park, was assassinated and the Fourth Republic collapsed. A new military junta seized the power in a political vacuum. They soon organized the Legislative Council of the National Defense Emergency Measures Board (a de facto military junta) and set forth an ambitious plan to build 5 million houses within 10 years in 1981 . The 5 million houses were equivalent to the housing stock of the whole country at that time. To back the plan, the government seriously needed "a revolutionary method of land development" to secure large tracts of cheap land for housing. The Housing Site Development Promotion Act was thus enacted in December 1980. The Housing Site Development Project in accordance with the act has since replaced LR projects as a dominant land development method. Since this time, most new towns and new urban districts were constructed in accordance with this act. In this chapter hereinafter, PPD refers to the Housing Site Development Project unless otherwise stated.

\section{Public purchase and development}

Large-scale development of greenfield land by compulsory purchase began for industrial complexes in the early 1960s when the military regime launched industrialization as a dominant national program. Until then, industrial sites were the result of free choice by individual corporations. In December 1973, the government enacted the Industrial Site Development Promotion Act (currently the Industrial Sites and Development Act) to further promote industrial site development. Most of the industrial complexes since have been developed in accordance with this act. In the 1990s, various laws concerning industrial sites were merged into the present Industrial Site Development Act (MOLIT, 2012). Government support is normally required for industrial complex development in underdeveloped areas where private companies cannot be expected to invest. The South Korean government has provided some support for industrial complex development, including investment capital support, tax benefits for project executors and tax/financial support for tenant companies. Except these supports, the Industrial Site Development Project is almost the same as the Housing Site Development Project in terms of operational processes. This chapter will concentrate on Housing Site Development Project as the major PPD project in South Korea. 
The Housing Site Development Promotion Act intended to secure cheap land mostly through the re-zoning of greenfield land for urban use. On the authority of the act, the Minister of MOLIT (up until 2010) and metropolitan city mayors and Do (province) governors (after 2010) can designate an area as a Housing Site Development Zone. They also designate the developer principally among the state, local governments and public corporations. After 1999, corporations established by public developers and private housing developers through joint investment also can implement housing site development projects. The public developer can purchase land by compulsion. After land is developed, it is provided to housing developers and builders at varying prices according to the use of the land and regions. For example, land for small public rental housing is provided at 60-100 percent of development costs, land for housing with $85 \mathrm{~m}^{2}$ or less in net floor area at 90-100 percent, and other land for residential use at appraised value. The land value of a site should be calculated by taking the arithmetical average of the amounts appraised by normally three appraisers. The prices of land for commercial use are to be determined by competitive bidding. ${ }^{6}$

The Housing Site Development Promotion Act is the most powerful act for land development in South Korea. Only an authoritarian regime like the Fifth Republic government would have been able to enforce such an act. Before 2000, in projects such as the Preparation Project for a Group of Housing Sites as well as the Housing Site Preparation Project, public developers had the power to expropriate land, but the development zone was to be designated within urban planning zones. In comparison, for the Housing Site Development Project, greenfield areas outside urban planning zones can be designated for development. Once a plan for Housing Site Development Project is approved, the change of zoning of the area prescribed in the National Land Planning and Utilization Act is deemed as granted. Public developers recoup all the costs of their investments in the public investments that are necessary for the development, by making sure that the selling prices of the building sites generate sufficient income to cover all their costs.

PPD based on Housing Site Development Promotion Act has been effective in providing large tracts of land for mass housing construction with the necessary infrastructure and service facilities and virtually no financial burden on the government. The latter half of the 1980s to the early 1990s was another period of property boom as represented in land prices in Figure 11.2, and the government could build numerous new towns and new urban districts through PPD in short periods of time. Between 1990 and 1995, five new towns were constructed, accommodating approximately a population of 1.2 million around Seoul. Then another 12 New Towns were constructed or are under construction accommodating a population of 1.7 million. Ten innovative cities, five enterprise cities and the new administration city were also constructed or are under construction by PPD (MOLIT Policy Data). PPD provided $1,018 \mathrm{~km}^{2}$ of urban land nationwide (MOLIT Statistics System). This is equivalent to more than 40 percent of the urban built-up area of the nation, which was $2,750 \mathrm{~km}^{2}$ as of 2014 (OECD. Stat, 2019). 
However, in PPD as well, it was becoming difficult to provide cheap urban land due to the conflicts over land valuation and compensation and the prevalence of land speculation, which helped inflate development costs and land prices. In LR, there were almost always disputes over the rate of land reduction, that is, the ratio of contribution to the original parcel of land. The rate reflects the valuation of previous parcels of land and redistributed land parcels after readjustment. Until the 1970s, the replotting plan was to be decided in consideration of the location, land category, area, soil quality, utilization status, environment and other factors. After 1980, replotting was based on appraised prices. In this case, the developer would commission the appraisal of land price to a certified public appraisal agency and decide the final price through the deliberation of the Land Appraisal Council. In any case, in LR, land valuation is essentially based on the expectation on future development gains.

In PPD, land valuation and compensation ${ }^{7}$ are to follow the principle of the restitution of development gain. The Constitution (Article 23) provides that in case of "Expropriation, use or restriction of private property from public necessity ... just compensation shall be paid". A researcher who studied the related laws and judicial precedents suggested that "just compensation" here meant in principle compensation that did not include expected development profit from future development (Lee, 2011). However, in reality, landowners rarely accept appraised prices that do not reflect future development gains for the compensation of their land. For landowners, "just compensation" means prices of land actually traded in the market, that is, prices that reflect future development gains. This has become the main source of conflicts in PPD.

According to the Act on Acquisition of and Compensation for Land, Etc. for Public Works Projects, land price is to be assessed by three appraisal businesses in PPD projects. Each of the three parties involved in a PPD project-the landowners, the public developer and the local government that has the right to approve the project - is to recommend one appraisal business each. The appraisal must be based on the Officially Assessed Land Prices. ${ }^{8}$ Final compensation prices are to be assessed upon the consideration of land rents, lease rents, methods of use, period of use, prices and so on of similar kinds of land in the vicinity. If the developer fails to negotiate with the landowners on the compensation plan, the developer may file an application for adjudication with the competent Land Tribunal. Landowners who are dissatisfied with the adjudication rendered by the Land Tribunal may file an objection to the Central Land Tribunal. Any developer, landowner or person concerned who is dissatisfied with the adjudication may institute administrative litigation. However, in most cases, the issue of land valuation and compensation is settled through politics rather than through the administrative and judicial processes.

There was almost always strong opposition by landowners to land expropriation. Until the mid-1980s, under the strong government authority of the Fifth Republic, however, landowners' resistance could not significantly affect the plans to purchase land by compulsion. At that time, press activities and freedom of speech were strictly controlled and landowners' grievances did not attract 
public attention. That Fifth Republic ended by the June Democratic Uprising, a nationwide democracy movement in June 1987. The demonstrations forced the military-backed regime to revise the constitution to institute democratic reforms, which led to the establishment of the democratic Sixth Republic. The direct presidential election, abolished in 1972, and the local autonomy system, suspended in 1962, were restored. Press censorship and control of the press was abolished, free trade union movement was ensured, and the labor movement, suppressed until then, came to the fore. A wave of labor disputes, started in the heavy and chemical industrial estates in the south east coastal areas, spread nationwide, demanding higher wages and better working and living conditions. The power balance between the government and landowners in PPD projects changed in favor of the latter. It was in the two new town development projects at the end of the 1980s that PPD met with the unprecedented strong defiance of landowners and residents (Lim, 1994).

The chronic housing shortage re-emerged as an urgent policy issue. As shown in Figure 11.2, the housing supply ratio fell to its lowest level in the mid-1980s. Recognizing this as a source of social unrest, the new government of the Sixth Republic put out a plan to build 2 million houses within four years. As part of the plan, the government decided to build two additional new towns around Seoul, Bundang and Ilsan through PPD. Bundang was a greenfield site with an area of roughly $20 \mathrm{~km}^{2}$ located $20 \mathrm{~km}$ south of the city center of Seoul. Ilsan, with an area of $16 \mathrm{~km}^{2}$, is located $20 \mathrm{~km}$ north of the city center. On the news of the development plan, landowners and residents in both areas organized the Residents Association for Campaign Against Development and tried to deter the plan by every possible means. They staged sit-in demonstrations at the development sites, the city halls, political party headquarters and the National Assembly, and even occupied streets, highways and railways. This attracted the attention of scholars, urban experts and politicians. In the National Assembly, politicians even in the ruling party urged the government to adopt measures to pacify increasing popular discontent. Political organizations and human rights organizations intervened in support of the campaign of landowners and residents against the development plan. Urban experts criticized the rough-and-ready development plans for not properly considering the effects on the lives of the residents and the impacts of the population increase in the capital and regional traffic and the environment. The government could carry on the projects only after it made a major concession to the demand of the landowners.

Table 11.3 is a comparison of compensation costs between Gaepo in 1981 and Bundang and Ilsan in 1989. It shows that compensation costs were more generous in Bundang and Ilsan than in Gaepo despite the superior locational advantages of Gaepo. Gaepo is located in the Gangnam District, now one of the nation's most prestigious areas with expensive properties. It was also one of the first areas designated for the Housing Site Development Project as a part of the Five Million Housing Construction Plan. In 1981 it was mostly farmland. Landowners demanded full compensation for their properties: compensation at prices similar to those in the already developed neighboring areas. Some 
Table 11.3 Compensation in PPD, a comparison between two projects in different times

\begin{tabular}{|c|c|c|c|}
\hline Year & Project Area & Absentee Landowners & Resident Landowners \\
\hline 1981 & Gaepo* & $\begin{array}{l}\text { KRW } 65,345 \text { per } 3.3 \mathrm{~m}^{2} \\
\text { of land }\end{array}$ & $\begin{array}{l}\text { KRW } 65,345 \text { per } 3.3 \mathrm{~m}^{2} \text { of land and } \\
\text { new housing plots }\left(230 \mathrm{~m}^{2}\right) \text { at cost }\end{array}$ \\
\hline 1989 & $\begin{array}{l}\text { Bundang \& } \\
\text { Ilsan }\end{array}$ & $\begin{array}{l}\text { KRW } 222,000 \text { per } \\
3.3 \mathrm{~m}^{2} \text { of land } \\
\text { (Bundang) and KRW } \\
191,000 \text { per } 3.3 \mathrm{~m}^{2} \\
\text { of land (Ilsan); and } \\
\text { new apartments at } \\
\text { regulated prices. }\end{array}$ & $\begin{array}{l}\text { KRW } 222,000 \text { per } 3.3 \mathrm{~m}^{2} \text { of land } \\
\text { (Bundang) and KRW } 191,000 \\
\text { per } 3.3 \mathrm{~m}^{2} \text { of land (Ilsan); new } \\
\text { apartments at regulated prices or } \\
\text { new housing plots ( } 200 \text { to } 230 \mathrm{~m}^{2} \text { ) } \\
\text { at } 50 \text { to } 60 \% \text { of appraised prices; } \\
\text { commercial land or new shops at } \\
\text { appraised prices to shop owners and } \\
\text { farmers on request. }\end{array}$ \\
\hline
\end{tabular}

Notes: Extract from Table 3.7, Lim op.cit.

* The case of Korea National Housing Corporation's project in Gaepo

resisted the development plan, not for higher compensation payment but for the preservation of their land, which was home to their ancestral burial grounds. There were, however, no forces for them to appeal to. Mass media was under the strict control of the government: no report of public discontent could be published. Most landowners had no choice but to comply with the KNHC's proposal (Lim, 1994).

\section{Urban development with LR and PPD combined}

After the incidents in the two new towns, the effectiveness of PPD in providing cheap land weakened as compensation costs rose and landowners' resistance to compulsory land purchase hardened. Land speculation both in development areas and neighboring greenfield areas also hampered just compensation. Furthermore, the process of land valuation and compensation has been increasingly influenced by populist politics as political democratization and local autonomy progressed. The heads of local governments elected by popular vote tended to be sympathetic with the landowners and residents in the development areas. They, with the right of approval of the development plan, often influenced the land valuation and compensation to the advantage of landowners. The appraisal businesses nominated on local governments' and landowners' recommendations tended to inflate compensation prices. Public developers often preferred to do the land compensation work through politics rather than through the complicated administrative processes so as to save financial costs that might be caused by any delay in the process of compensation (KICAC, 2007).

Another problem with PPD was that it often passed over urban plans. Successive governments from the 1970s to the 1990s were obsessed by mass housing construction to ease the aggravating problem of housing shortage. The Housing Site Development Promotion Act was an offspring of that housing policy, which, 
rather than urban planning, has led PPD projects since the 1980s. The government often designated PPD projects normally in greenfield areas in the suburbs outside urban planning zones where land prices were cheap. Accordingly, PPD was under increasing criticism for disorderly development of national territory, resulting in inefficient regional networks of traffic and infrastructure services. New towns scattered around Seoul were once criticized as bed towns, generating long-distance commuting and aggravating traffic congestion. Planning circles and environmental organizations criticized PPD for its ignorance of urban plans and its damaging effects on the natural environment. Some criticized compulsory purchase of land for its possible infringement on the private ownership of land. Others doubted whether PPD was fit for the purpose of the act concerning land expropriation, the Act on Acquisition of and Compensation for Land, etc. for Public Works Projects. The act justifies compulsory land purchase only for public welfare works while developed land in PPD projects was also sold to private builders (Lim, 1994).

Eventually, a fundamental amendment of the Housing Site Development Promotion Act, the most powerful applicable act for PPD, was proposed in the National Assembly. A long discussion about the amendment in the National Assembly and the government resulted in the enactment of the Urban Development Act in 2000. It was an act with LR and PPD combined. LR, almost abandoned after the 1980s, was thus brought back into the land development system. The idea was to reduce conflicts over the land valuation and compensation by allowing landowners compensated in the form of replot for parts or all of their original land. It also aimed at ensuring that land development projects were implemented within the scope of urban plans. The act also allowed private developers to participate in land development in response to the increasing criticisms on the monopolization by public developers of land development.

Along with the establishment of Urban Development Act, discussions continued about the abrogation of the Housing Site Development Promotion Act. An abolishment bill of the act argued that $246 \mathrm{~km}^{2}$ of land developed through PPD was unsold as of 2013 and that the housing supply ratio greatly increased (the ratio exceeded 100 percent in 2013), so there was no need to develop land on a large scale for housing any longer (MOLIT, 2014a). The Housing Site Development Project is, however, still considered more effective for land development than the new Urban Development Project in terms of the simplicity and speediness of the development process. Table 11.4 is a comparison of the three major current land development systems in South Korea.

\section{Issues for consideration}

Ultimately, South Korea managed to meet the growing demand for urban land during the period of its rapid urbanization under the authority of strong governments. LR contributed to the readjustment of deteriorated or damaged urban areas during the 1950s and to the planned expansion of new urban land until the 1970s. Since the 1980s, however, land development was led by the 
Table 11.4 Land development methods in South Korea

\begin{tabular}{|c|c|c|c|}
\hline $\begin{array}{l}\text { Land } \\
\text { Development } \\
\text { System }\end{array}$ & $\begin{array}{l}\text { Public Purchase and } \\
\text { Development (PPD) }\end{array}$ & $\begin{array}{l}\text { Land Readjustment } \\
\text { (LR) }\end{array}$ & Urban Development \\
\hline Applicable Act & $\begin{array}{l}\text { Housing Site } \\
\text { Development } \\
\text { Promotion Act }\end{array}$ & $\begin{array}{l}\text { Urban Development } \\
\text { Act }\end{array}$ & $\begin{array}{l}\text { Urban Development } \\
\text { Act }\end{array}$ \\
\hline Method & $\begin{array}{l}\text { Purchase } \rightarrow \\
\quad \text { development } \rightarrow \text { sale }\end{array}$ & $\begin{array}{l}\text { Replotting and } \\
\text { development } \rightarrow \\
\text { disposal of replot }\end{array}$ & $\begin{array}{l}\text { PPD or LR, or a } \\
\text { combination of } \\
\text { both }\end{array}$ \\
\hline Developer & $\begin{array}{l}\text { The state, local } \\
\text { governments, } \\
\text { public development } \\
\text { corporations } \\
\text { Cooperative of } \\
\text { landowners } \\
\text { Partnership between } \\
\text { above actors }\end{array}$ & $\begin{array}{l}\text { Local governments, } \\
\text { public development } \\
\text { corporations } \\
\text { Cooperatives of } \\
\text { landowners } \\
\text { Real estate trust } \\
\text { company }\end{array}$ & $\begin{array}{l}\text { The state, local } \\
\text { governments, } \\
\text { public } \\
\text { development } \\
\text { corporations } \\
\text { Cooperatives of } \\
\text { landowners } \\
\text { Public-private } \\
\text { Partnerships }\end{array}$ \\
\hline Merits & $\begin{array}{l}\text { Speedy execution of } \\
\text { development projects } \\
\text { Planning free from } \\
\text { the intervention of } \\
\text { property owners }\end{array}$ & $\begin{array}{l}\text { Least financial burden } \\
\text { on developers }\end{array}$ & $\begin{array}{l}\text { Property rights of } \\
\text { landowners are } \\
\text { respected } \\
\text { Less financial burden } \\
\text { at the initial stage }\end{array}$ \\
\hline Demerits & $\begin{array}{l}\text { Heavy financial burden } \\
\text { at the initial stage } \\
\text { Conflicts over land prices } \\
\text { and compensation }\end{array}$ & $\begin{array}{l}\text { Planning restricted } \\
\text { by landowners' } \\
\text { intervention } \\
\text { Development period } \\
\text { is likely to be } \\
\text { prolonged }\end{array}$ & $\begin{array}{l}\text { Complicated } \\
\text { development } \\
\text { process }\end{array}$ \\
\hline
\end{tabular}

government's mass housing construction plans rather than urban plans. PPD based on the Housing Site Development Promotion Act was designed to provide large tracts of cheap land for housing and has since become a major land development method. Almost all New Towns, new urban districts and large apartment complexes were built by PPD. Both LR and PPD were self-financing development systems. They financed development with their own development gains. This meant that the government could build numerous new towns and new urban districts with little financial burden on itself during the period of rapid urbanization.

Kitay (1985), who carried out surveys and case studies on land acquisition in a number of countries including South Korea, suggested some prerequisites for effective LR in developing countries: (1) national, provincial, and local support is essential, (2) key ministries must be sympathetic, (3) in most countries, major new enabling legislation is required, (4) a country must possess an efficient system of cadastration or title registration, (5) an adequate corps of well-trained, objective appraisers of real property is necessary and (6) highly skilled negotiators 
and administrators are essential. In my view, these are basic requirements for almost all land development systems including PPD. South Korea fulfilled most of the prerequisites by the early 1960s. What is missing here is the financial capacity for land development. In South Korea, private funds of a speculative nature, accumulated along with the rapid economic growth and increase in households' income, have formed funds for land development. Land development based on such speculative funds has raised challenging points at issue along with its achievement.

The first challenge is conflicts over development gains. The conflicts between local governments and landowners in LR over the replotting plan and that in PPD over land valuation and compensation are all a matter of the distribution of development gains. Land development yielded quite substantial development gains. In LR, a large part of the development gains went to the landowners as mentioned earlier. PPD was designed to use the development gains for public purposes. Now, however, a large part of the gains goes to landowners and speculative investors. Furthermore, public developers often inflate development gains for their own interests. They tend to sell larger portions of developed land to private developers at appraised prices that are almost market prices rather than provide land for social needs such as public rental housing for low-income people. They often inflate development costs by adding irrelevant expenses to these costs (KICAC, 2007). Local government-invested development corporations began to enter into PPD in 1999. With the enactment of the Urban Development Act, private developers are now joined in PPD, though conditionally. These developers now compete with each other for land development. Accordingly, there is a growing need to socialize a fair share of development gains. In fact, the government introduced a system of restitution of development gains by enacting the Restitution of Development Gains Act in 1989. It intended to curtail expectations of excessive development gains through speculative investment. Developers of a large tract of land should pay a development charge, that is, 25 percent of development gains to the relevant local government. Non-administrative public developers such as public corporations also have to pay 50 percent of that development charge (MOLIT, 2014b).

The second is also associated with the issue of development gains, the control of property speculation. In LR, as stated earlier, developed land was often circulated among many speculative investors before being passed into the hands of end users, generating a land price bubble. Some landowners left returned land idle, waiting for a further rise in land prices. This hampered the plans of city governments to complete new urban districts within a given period. In PPD, as land valuation and compensation have become increasingly profitable to landowners and residents, speculation in land to be expropriated became prevalent in various forms: squatting aimed at compensation, partitioning of existing houses into several compartments or remodeling of open sheds or cattle sheds into rooms for rent to new tenants. False resident registration also prevailed, aimed at the titles to rental apartments for tenant residents. All of these disturbing practices hampered the normal process of compensation. Speculative investments 
in nearby areas of the development project, where land prices rose often higher than in the project area, also distorted fair compensation (Lim, 1994).

The government periodically carried out anti-speculation measures, including heavy taxation of idle land and real estate transactions in speculation-prone areas. ${ }^{9}$ The government often organizes the Speculation Investigation Squad to monitor speculative activities in the area, and, when necessary, investigates the sources of funds used for property transactions and levies heavier taxes on speculative transactions. At development sites, public developers also take measures responding to property speculation in development areas. They sometimes employed private guard companies to monitor squatter house building or the illegal remodeling of existing houses. The Permission of Land Transaction system is perhaps one of the most powerful means to control land speculation. ${ }^{10}$ Once an area is designated as a Land Transaction Permission Area, heavy taxes are levied on speculative real estate transaction. This system was effective in regulating speculation, particularly in the neighboring areas of development zones. On the whole, these measures seem to have been effective in regulating land speculation, though they were unable to put an end to property speculation.

The third issue is the discord between land development, particularly PPD, and urban planning. Large-scale land development has mostly been carried out in accordance with various development acts, including the Housing Site Development Promotion Act, which take precedence over normal planning acts. ${ }^{11}$ Urban planning has thus been led by land development instead of guiding the latter. This often disturbs the urban planning of cities, particularly in provincial regions (KRIHS, 2014a). In 2002, the government restructured the legal system to ensure "no development without spatial planning". The Urban Planning Act and the Land Compartmentalization and Rearrangement Project Act were consolidated into the National Land Planning and Utilization Act. The Land Compartmentalization and Rearrangement Project, that is, LRP and the Preparation Project for a Group of Housing Sites and the Preparation Project for a Group of Industrial Sites were combined into the Urban Development Project as defined in the Urban Development Act. This was an effort to place land development under the guidance of urban planning and thereby minimize the problem of discordance between land development and urban or other relevant spatial planning.

All these problems remain ongoing issues, from which some lessons may be drawn and shared with other rapidly urbanizing countries. First, it is important to appropriately control the conflicts over development gains. For this, it is critical to minimize the room for interest groups to intervene unfairly in, for example, land valuation and compensation. The government needs to take the initiative to formalize and institutionalize more precise rules and guidelines for the development process, including replotting in LR and land valuation and compensation in PPD. Second, a proper control of land speculation and conflicts over development gains is essential. Land in a capitalist society means landed property: its development is a process by which certain gains are realized from landownership. It thus involves various forms of land speculation and conflicts of interests over 
development gains. It is especially important in countries where land development is greatly affected by speculative investment, as experienced in South Korea. Finally, the land development system needs to be designed in such a way that it is led by urban planning or other relevant spatial planning rather than vice versa.

\section{Notes}

1. GDPC(2013) gives details of the evolution of land development laws in South Korea.

2. The Farm Land Reform carried out in 1950 reditributed agricultural land to tillers with an upper limit of three hectares for each farm household. As a result, most agricultural landowners were still small holders in the 1970s.

3. Average annual CPI inflation rates fluctuated between 7 and $30 \%$ in the 1960 s and 10 and $25 \%$ in the 1970 s (Inflation.eu, World wide inflation data)

4. Overall story here on Youngdong LRP is based on $\operatorname{Lim}(1994)$. See also $\operatorname{Sohn}(2003)$ for some political motivation and inside facts of the project, and Appendix 2 of UN-Habitat(2019) for more technical information.

5. An estimation from Table 4.1 in $\operatorname{Lim}$ (op. cit.), which was compiled based on standard prices assessed by Korea Appraisal Board.

6. Administrative Guides on Housing Site Development Projects (MOLIT Instruction No. 1247) prescribes the details.

7. KRIHS (2014b) gives a full explanation of the land expropriation and compensation system in South Korea

8. The MOLIT Minister inspects and assesses each year a reasonable price per unit area of representative land and publicly announce it in accordance with Act on the Public Announcement of Real Estate Values(Article3)

9. The Minister of Strategy and Finance, on the request of MOLIT Minister, may designate an area where the increase rate of real estate price is higher than that of the national consumers price, and land price has increased excessively as speculation-prone area(Article 104-2, Income Tax Act)

10. The Minister of MOLIT may designate an area where speculative land transactions are prevalent as an area subject to land transaction permission area. In the area those who want to buy and sell land should jointly obtain permission from the local government. They need to report on the use of land and the sources of purchasing funds. And the buyers should use the land as reported for a certain periods, for example at least two years in case of farm land, three years for housing (Article 10, Act on Report on Real Estate Transactions, Etc.)

11. There are many other development acts that adopt the same PPD as defined in Housing Site Development Acts for land development. They include Industrial Site and Development Act, Special Act on the Development of Enterprise Cities, Special Act on the Construction and Support of Innovative City, Special Act on the Construction of Administrative City, Act on the Development and Management of Logistics Facilities and so on. See GDPC (2013) for details.

\section{References}

Cho, J. H. (1990). "Evolution of Residential Land Development Policies and Programs in Korea." Paper presented at International Conference on Korean Housing Policies organized by Hyundai Research Institute. November 29-30, Seoul. 
Das, D. (1992). Korean Economic Dynamism. London: Macmillan.

FKI (Federation of Korean Industries) (1987). "Korea's Economic Policies (1945-1985).” Seoul: Federation of Korean Industries.

GDPC (Global Development Partnership Center) (ed.) (2013). "Land Development and Management Laws, Korea Research Institute for Human Settlement," GDPC Study Report 2013-01.

Hamilton, C. (1986). Capitalist Industrialization in Korea. Boulder: Westview Press.

Inflation.eu, Worldwide inflation data, 'Historic Inflation South Korea-CPI Inflation." Available at: www.inflation.eu/inflation-rates/south-korea/historic-inflation/cpiinflation-south-korea.aspx. [Accessed November 1, 2019].

KICAC (Korea Independence Commission Against Corruption) (2007). A Plan for the Enhancement of Fairness and Clarity Enhancement in Public Land Development (in Korean).

Kim, K. (1980). "Structural Characteristic of Labour-Capital Relationship in Korea," in C. Lim and M. Bae (eds.), Korean Labour Economy. Munhahkkwa-Chisung-Sa. Seoul: Moonii Publishing (in Korean), pp. 171-206.

Kitay, Michael G. (1985). Land Acquisition in Developing Countries, Policies and Procedures of the Public Sector, with Surveys and Case Studies from Korea. Boston: India, Thailand, and Ecuador, Oelgeochlagcr, Gunn \& Hain, Publishers, Inc.

KNHC (Korea National Housing Corporation) (1992). Reformation of Institutional Systems to Promote the Improvement of Substandard Housing (in Korean).

KNHC (1996). 1996 Yearbook of Housing Statistics.

KNHC (2002). 2002 Yearbook of Housing Statistics.

KOSIS (Korean Statistical Information Service). "Urbanization Rate." Available at: http://kosis.kr/statHtml/statHtml.do?orgId=101\&tblId=DT_2KAA204 [Accessed November 1, 2019].

KRIHS (Korea Research Institute for Human Settlement) (2008). Sea Change of National Territory of South Korea, a 60-year History, 2. Policy Implementation. Sejong: KRIHS (in Korean).

KRIHS (2014a). A Study on Establishing the Policy for Public Land Supply System in PostDevelopment Era. Sejong: KRIHS 2014-34 (in Korean).

KRIHS (2014b), The Expropriation and Compensation System in Korea, 2013 Modularization of Korea's Development Experience. Sejong: KRIHS.

Lee, H. (2011). "Improvement of Institutional System to Mitigate Conflicts Associated with Land Expropriation in Public Projects," KDI Policy Forum Series No. 238. Korea Development Institute Available www.kdi.re.kr/research/subjects_view.jsp?pub_no=1 1990\&pg $=7 \& p p=10 \& \operatorname{mcd}=001003002$ [Accessed August 7, 2019] (in Korean).

LH (Land and Housing Corporation). (2016). 2016 Year Book of Land \& Housing Statistics. Jinju: LH.

LHI (Land and Housing Institute). (2019). Urbanization and Regeneration in Korea. Seongnam: LHI.

Lim, S. H. (1994). "Landowners, Developers and Rising Land Cost for Housing, the Case of Seoul, 1970-1990," Ph. D. Thesis, London: University College London.

Mason, E. S., Kim, M. J., Perkins, D. H., Kim, K.S. and Cole, D. C. (1980). The Economic and Social Modernization of the Republic of Korea. Cambridge. MA: Harvard University Press.

MOLIT (Ministry of Land, Infrastructure and Transport) (2012), Korea's Development Experience Modularization - Industrial Complex Development Policy in Korea. Seoul: KRIHS.

MOLIT (2014b). A New Paradigm for and System Improvement of the Restitution of Development Gains, prepared by KRIHS (in Korean). 
MOLIT (2019a). Current Status of Urban Planning, Statistics as of 2018, News Release, June 24 (in Korean).

MOLIT (2019b). Land Price Fluctuation Rate (\% on year-on-year basis) 1975-2018. August 23 (in Korean).

MOLIT Policy Data. "New Towns, Concept and Construction Status." Available at: www.molit.go.kr/USR/ policyData/m34681/dtl?id=522. (in Korean) [Accessed November 1, 2019].

MOLIT Policy Data. "Current Status of Enterprise City Construction." Available at: https://bit.ly/3iFnfMO. [Accessed November 1, 2019] (in Korean).

MOLIT Policy Data. "Current Status of Innovative City Construction." Available at: http:// innocity.molit.go.kr/v2/submain.jsp? sidx=211\&stype =1\&bmode=view\&idx $=4 \&$ search key_n=\&search_val_v=\&currentPage=1. [Accessed November 1, 2019] (in Korean).

MOLIT Statistics System. Designation and Supply of Residential Area. December 31, 2018. Available at: https://bit.ly/2FsyV7B. [Accessed November 1, 2019] (in Korean).

NGII (National Geography Information Institute) (2017). The National Atlas of Korea, 3-4 Economy and Industry. Available at: http://nationalatlas.ngii.go.kr/us/index. php. [Accessed November 1, 2019].

OECD.Stat. (2019). "Dataset: Built-up Area and Built-up Area Change in Functional Urban Areas, Korea." Available at: https://stats.oecd.org/Index.aspx? DataSetCode=BUILT_ UP_FUA. [Accessed November 1, 2019].

Payne, G., A. Piaskowy and L. Kuritz (2014). "Land Tenure in Urban Environments, the United States Agency for International Development's Division of Land Tenure and Property Rights," Issue Brief. Available at: www.land-links.org/wp-content/uploads/ 2016/09/USAID_Land_Tenure_Urban_Brief_061214-1.pdf. [Accessed November 1, 2019].

Renaud, B. (1989). "Compounding Financial Repression with Rigid Urban Regulations: Lessons of the Korean Housing Market," Review of Urban and Regional Development Studies 1, pp. 3-22.

Seoul Solution (2015). "Gangnam Development Plan" written by Kang, M.K. Available at: https://seoulsolution.kr/ko/content/\%EA\%B0\%95\%EB\%82\%A8\%EA\%B0\%9C\%E B\%B0\%9C\%EA\%B3\%84\%ED\%9A\%8D. [Accessed November 1, 2019] (in Korean).

SI (Seoul Institute) (1999). Guidelines for the Residential Environment Program in Seoul. Seoul: Seoul Institute (in Korean).

SI (2010). "Housing and Construction," in Changing Profile of Seoul: Major Statistics and Trends, the 2010 revision. Seoul: Seoul Institute (in Korean).

SMG (Seoul Metropolitan Government). (2017). White Book on Land Readjustment Project in Seoul. 2 (in Korean).

SMG (1991). 1990 Statistical Yearbook (in Korean).

SMG. Statistics on Built-up Area of Seoul 2003-2017. Seoul Open Data Center. Available at: https://data.seoul.go.kr/dataList/datasetView.do?infId=569\&srvType=S\&service Kind $=2$ [Accessed November 1, 2019] (in Korean).

Sohn, J. (2003). Seoul Urban Planning Story. 3. Paju: Hanwool (in Korean).

UN Habitat (2019). Land Readjustment in the Republic of Korea: A Case study for Learning Lessons. Nairobi: United Nations Human Settlements Programme.

United Nations (2019a). World Urbanization Prospects The 2018 Revision. Department of Economic and Social Affairs Population Division, New York. ST/ESA/SER.A/420.

United Nations (2019b). World Population Prospects 2019 Highlights. Department of Economic and Social Affairs Population Division, New York ST/ESA/SER.A/423.

World Bank National Accounts Data. Available at: https://data.worldbank.org/indicator/NY.GDP.PCAP.CD?locations=IN-KR [Accessed August 20, 2019]. 


\title{
12 Knowledge-policy nexus \\ Policy research institutes and the urban development regime in Korea
}

\author{
Se Hoon Park
}

\section{Introduction: policy research institutes in the Korean urban regime}

Policy research institutes (PRIs) ${ }^{1}$ in the Republic of Korea (Korea hereafter) have played a pivotal role in the nation's economic and social development since their inception in the early 1970s. The PRIs have been pipelines for transferring the knowledge and policy experiences of advanced countries into the nation, as well as sources of technical information for decision-makers in the government. Following the Korea Development Institute (KDI), founded in 1971 as the first national think tank, many PRIs in almost every policy field have been established to fill the gap between academic knowledge and policymaking. Currently, Korea operates 26 national PRIs under a governing body, the National Research Council for Economic Humanities and Social Science (NRC). The Korean PRI system is quite systematic and well organized.

This is the case in the urban and regional policy in Korea. Throughout its high economic growth era, Korea has developed a unique institutional arrangement in the urban development sector to facilitate effective and efficient land development. In this "urban development regime", many public agencies are playing important roles in policymaking and policy implementation, and the PRIs are an integral part of the regime. ${ }^{2}$

At the national level, the Korea Research Institute for Human Settlements (KRIHS) was established in 1978 as a government think tank, and has remained as a planner and knowledge provider in the urban sector in Korea. All major urban policy issues, ranging from the Comprehensive National Territorial Plan (CNTP) to national urban regeneration schemes, have been reviewed and advised by KRIHS. The national government, particularly the Ministry of Land, Infrastructure and Transport (MOLIT), and KRIHS often work together in a concerted way to produce optimized policy alternatives. At the local level, PRIs are now operated by all metropolitan and provincial governments as their think tanks and, at the same time, function as an integral part of the respective urban development regime.

A think tank itself is not special. PRIs have proliferated in many countries and are playing an important role in producing and influencing public policies. 
It would be worth noting the several definitions of PRIs offered by Western scholars. Kent Weaver describes them 'universities without students' and 'advocacy tanks' (Weaver, 1989). Andrew Rich defines them as 'independent, noninterest based, non-profit organizations that produce and principally rely on expertise and ideas to obtain support and to influence the policy process' (Rich, 2004). Diane Stone identifies them as 'non-profit organizations engaged in the analysis of public policy issues independent of government, political parties, and interest groups' (Stone, 1996).

Obviously, the definitions offered here are grounded on the experiences of Western PRIs and are not suitable for those of Korea. They commonly place an emphasis on the "independence" of the PRI on the grounds that independent views are considered to be vital for producing rational policy alternatives. The world-renowned PRIs such as the Brookings Institute in the US and Chatham House in the UK are all independent and private organizations. In contrast, major PRIs in Korea are heavily dependent on the government in terms of finance and governance structure. Private and civil PRIs are significantly side-lined, though their roles have been expanding recently. Why had the Korean government built such a large-scale governmental PRI system, and how do policymakers benefit from the PRIs in their policymaking? How did this system work for the overall urban development regime, and how does it persist in the current neoliberal socioeconomic environment in Korea?

One prevailing explanation for this is the argument based on developmental state theory (Karthik et al., 2010; Mo, 2005). Developmental state theory has focused on the distinctive institutional features of the East Asian states such as business-government cooperation, bureaucratic autonomy and capacity, and authoritarian rule. Under these institutions, the state has played a dominant role in mobilizing society and the business sector for economic development (Johnson, 1982; Amsden, 1989; Woo-Cumings, 1999). This perspective, however, cannot explain why the Korean PRI system is more state-led than others such as those of Japan and Taiwan, countries that are also categorized as developmental states. The Korean system is more like those of France and Germany, which operate extensive government-sponsored research organizations under their interventionist tradition (Kim et al., 2009).

Having said that the developmental state perspective is effective in explaining the dominance of state over society and business, we need to go into further details to understand why Korea has developed such large-scale and governmentled PRI systems, and what particular roles PRIs are playing in the overall state-led institutional arrangement.

Here, rather than using a theoretical and structural analysis approach, I focus on the historical and contextual understanding on how the Korean PRIs have been conceived, developed and sustained until now. In following sections, after outlining the development of the PRIs in Korea, I highlight the three elements that have been shaping the current PRI system in Korea. The first is the knowledge production market in the early days of the PRIs. Unlike in Western countries, the knowledge production capacity in the Korean private sector was so 
marginal that the Korean government had utilized the PRIs as a channel to secure high-level professionals required for the nation's industrialization drive in the $1960 \mathrm{~s}$ and 1970s. The second is the government-PRI relations. The Korean government has built a unique governance system to provide the PRIs "independent management" to a certain degree in the late 1990s. By maintaining "some distance" between the government and the PRIs, the government could employ the PRIs more effectively under the democratized political environment. Last, Korea has built a strong partnership between the government and the PRIs under the state-led developmental regime. The regime, buttressed by comprehensive institutional and legal arrangement, has reinforced the role of the PRIs and vice versa.

\section{The development of policy research institutes in Korea}

PRIs in Korea can be categorized into four types by their governance structure: national, local, business and civil. The most influential PRIs are national ones, and the other types are expanding their roles with the rise of local governments, the business sector and civil society.

First and foremost, the PRIs in Korea were the result of the national government's deliberate efforts to produce knowledge for economic development (Lee, Bae and Lee, 1991; Yoon, 1992). Quasi-governmental research institutes started to pop up from the mid-1960s amid the national government's drive towards industrialization and modernization, and contributed to directing government policies. First, they were established in the field of economics and the sciences with the financial and technical support of US development cooperation. On the other hand, after Korea had enjoyed institutional local autonomy in the 1990s, local governments started to establish their own PRIs as tools for local policy development. In addition, large conglomerates began to run economic research institutes to voice their business interests to the government and the public. Independent PRIs reflecting the interests of civil society are becoming increasingly active and sometimes exercise influence on public policies, though they are small in scale in terms of organization and budget.

The Korea Institute of Science and Technology (KIST), the first government research institute, was founded in 1966, and the Korea Advanced Institute of Science and Technology (KAIST), as well as the first PRI, the Korea Development Institute (KDI), were founded in 1971. USAID tried to accelerate industrial development in Korea by channeling science and technology into industrial action in Korea with the establishment of KIST. Similarly, for the establishment of KDI, USAID provided considerable funds to the Korean Economic Planning Board of the Park Chung-hee government with a view to conduct competent independent research on public policy issues. For this matter, the KDI Act was promulgated by the Korean government on December 31,1970 , and the KDI Endowment Fund began to finance the KDI project in 1971 (Kim, T., 2014).

Currently, there are 26 PRIs in the fields of economics and social science which are supervised by a governing body, the National Research Council 
for Economics, Humanities and Social Sciences (NRC). Before 1999, PRIs were grounded in individual laws and directly controlled by their respective related ministries in terms of management and finance. The national government reformed the PRI system in 1999 by creating the NRC as an umbrella organization to administer PRIs in a bid to offer more independence in the management of the institutes and promote collaboration among them (see Table 12.1).

Since the 1990s, local governments began to follow the model of national research institutes, as the local autonomy system was reintroduced in 1995. Starting with the establishment of the Seoul Institute in 1992, 16 local governmentsponsored research institutes (hereafter local PRIs) have been established. Most local PRIs are funded by local governments but managed as independent entities based on local ordinances. They conduct research, surveys and networking activities to develop and improve local policies. As local autonomy has expanded recently, the role of the local PRIs has also increased.

Table 12.1 Policy research institutes under the NRC in Korea

\begin{tabular}{|c|c|c|}
\hline Name & Acronym & $\begin{array}{l}\text { Establishment } \\
\text { Year }\end{array}$ \\
\hline Korea Development Institute & KDI & 1971 \\
\hline KDI School of Public Policy and Management & KDIS & 1997 \\
\hline Korea Institute for Health and Social Affairs & KIHASA & 1971 \\
\hline Korean Educational Development Institute & KEDI & 1972 \\
\hline Korea Institute for Industrial Economics and Trade & KIET & 1976 \\
\hline Korea Rural Economic Institute & KREI & 1978 \\
\hline Korea Research Institute for Human Settlements & KRIHS & 1978 \\
\hline Architecture and Urban Research Institute & AURI & 2007 \\
\hline Korean Women's Development Institute & KWDI & 1983 \\
\hline Korea Information Society Development Institute & KISDI & 1985 \\
\hline Korea Energy Economics Institute & KEEI & 1986 \\
\hline Science and Technology Policy Institute & STEPI & 1987 \\
\hline The Korea Transport Institute & KOTI & 1987 \\
\hline Korea Labor Institute & KLI & 1988 \\
\hline Korean Institute of Criminology & KIC & 1989 \\
\hline National Youth Policy Institute & NYPI & 1989 \\
\hline Korea Institute for International Economic Policy & KIEP & 1989 \\
\hline Korea Legislation Research Institute & KLRI & 1990 \\
\hline Korea Institute for National Unification & KINU & 1990 \\
\hline The Korea Institute of Public Administration & KIPA & 1991 \\
\hline Korea Institute of Public Finance & $\mathrm{KIPF}$ & 1992 \\
\hline Korea Environment Institute & KEI & 1992 \\
\hline Korea Maritime Institute & KMI & 1997 \\
\hline $\begin{array}{l}\text { Korea Research Institute for Vocational Education and } \\
\text { Training }\end{array}$ & KRIVET & 1997 \\
\hline Korea Institute for Curriculum and Evaluation & KICE & 1998 \\
\hline Korea Institute of Child Care and Education & KICCE & 2005 \\
\hline
\end{tabular}

Source: NRC, visited on March 13, 2019 (www.nrc.re.kr). 
For example, the Seoul Institute was established in 1992 in the form of a foundation of the Seoul Metropolitan Government, based on the Act on the Establishment and Operation of Local Government-Invested Research Institutes and the Ordinance on the Promotion of the Seoul Development Institute. According to this ordinance, the Seoul Institute was established with the purpose of promoting the welfare of the citizens of Seoul and contributing to the sustainable development of Seoul. The Seoul Metropolitan Government has set up a fund to provide the necessary financial support for the operation of the Seoul Institute, and the important issues regarding the Institute must be reviewed by a board of directors.

Other research institutes include those established by private companies and political parties. However, these institutes have limitations in the autonomy and independence of their research, and conduct studies that reflect the interests of their founding organizations. On the other hand, there are independent research institutes that are not affiliated with any organization. Many of these institutes are provided funding through donations and membership fees and have roots in a civil society organization, such as the East Asia Research Institute, the Korea Research Institute and the Hope Institute. While these institutes play an important role as social innovators, many of them are under the stress of budget constraints (Kim and Kim, 2014).

The following table summarizes the functions and governance of the PRIs in Korea by type. As mentioned above, the national PRIs are dominant in size and influence, while independent research institutes are relatively weak. The national and local PRIs have secured stable financial resources due to legal stipulations on funding, but civil PRIs are usually operated with donations and membership fees, often meaning that they are forced with financial difficulties. On the other hand, civil PRIs have enjoyed the high level of independence that private research institutes do not have, while the national and local PRIs are somewhere in the middle (see Table 12.2).

\section{Factors behind the uniqueness of the Korean PRI system: the case of KRIHS}

\section{Knowledge production market}

One key element for why the national government had built such a large-scale PRI system was the unbalanced knowledge production market in the early stages of economic development in Korea. In the 1960s and 1970s, there was a critical deficiency of professionals in the private sector, including universities and research institutes. When the national government started to mobilize resources for economic development, the lack of knowledge was a critical concern. To cope with this, the national government made an organized effort to secure brainpower, particularly by focusing on getting scientists, engineers and other intellectuals who went abroad to foreign countries to return to Korea. The building of government-sponsored R\&D institutions, including PRIs, was an integral part 
Table 12.2 Types of policy research institutes in Korea

\begin{tabular}{|c|c|c|c|}
\hline Types & Role & $\begin{array}{l}\text { Governance } \\
\text { and Funding }\end{array}$ & Examples \\
\hline $\begin{array}{l}\text { National } \\
\text { Research } \\
\text { Institutes }\end{array}$ & $\begin{array}{l}\text { Research support } \\
\text { for national } \\
\text { government policy } \\
\text { development } \\
26 \text { institutes in all } \\
\text { policy areas }\end{array}$ & $\begin{array}{l}\text { Funded and operated } \\
\text { under the } \\
\text { governing body } \\
\text { of the National } \\
\text { Research Council } \\
\text { Independent } \\
\text { from individual } \\
\text { ministries }\end{array}$ & KRIHS, KDI, etc. \\
\hline $\begin{array}{l}\text { Local } \\
\text { Government } \\
\text { Research } \\
\text { Institutes }\end{array}$ & $\begin{array}{l}\text { Research support for } \\
\text { local government } \\
\text { policy development } \\
\text { Covering all policy } \\
\text { areas }\end{array}$ & $\begin{array}{l}\text { Funded by but } \\
\text { administratively } \\
\text { separated from } \\
\text { local governments }\end{array}$ & $\begin{array}{l}\text { Seoul Institute, } \\
\text { Gyeonggi Research } \\
\text { Institute, etc. }\end{array}$ \\
\hline $\begin{array}{l}\text { Private } \\
\text { Research } \\
\text { Institutes }\end{array}$ & $\begin{array}{l}\text { Supporting private } \\
\text { company activities } \\
\text { Mostly focused on } \\
\text { economic policies }\end{array}$ & $\begin{array}{l}\text { Funded and owned } \\
\text { by private } \\
\text { companies }\end{array}$ & $\begin{array}{l}\text { Korea Economic } \\
\text { Research Institute, } \\
\text { Samsung Economic } \\
\text { Research Institute, } \\
\text { etc. }\end{array}$ \\
\hline $\begin{array}{l}\text { Civil } \\
\text { Research } \\
\text { Institutes }\end{array}$ & $\begin{array}{l}\text { Alternative policy } \\
\text { development for the } \\
\text { general public }\end{array}$ & $\begin{array}{l}\text { Independent, and } \\
\text { funded by donors }\end{array}$ & $\begin{array}{l}\text { East Asia Institute, the } \\
\text { Hope Institute, etc. }\end{array}$ \\
\hline
\end{tabular}

of this strategy. Consequently, the set of programs was highly successful and repatriated intellectuals from abroad became important elements of the Korean techno-structure that began to emerge in the 1960s and 1970s (Yoon, 1992).

When KRIHS was founded in 1978, its key agenda was the establishment of the Second Comprehensive National Territorial Plan (CNTP). Before the foundation of KRIHS, the Ministry of Construction (MOC) mostly relied on in-house support groups, foreign consulting firms or individual professors at universities for their policy development and technical works. The first CNTP, the nation's top-level spatial development guideline, was established in 1971 with a help of a French consulting firm, Otam Metra. The MOC was increasingly pressed by the lack of adequate knowledge and stable technical support for policy development on a long-term basis (KRIHS, 1983).

In the late 1970s, there were a couple of planning schools in Korea, including the Seoul National University Graduate School of Environmental Studies, which provided a number of experts to KRIHS on its establishment later on. However, it was impossible to receive enough technical support from individual professors on increasing and diversifying territorial issues. The MOC had established an in-house research group, the Centre for Territorial Planning Research (CTPR), from 1969 in preparation for the first CNTP, but it was neither professional nor efficient enough. With a couple of research institutes like KDI as the model in 
mind, the top MOC officials began to discuss the establishment of KRIHS from 1977 (Um, 1993).

The first president of KRIHS, Dr. Noh Yung Hee, was a professor of Seoul National University, and a highly respected figure in the urban policy field. On the establishment of KRIHS, he requested two conditions from the MOC: first, a guarantee of the independent management of the institute without intervention from the MOC, particularly on the issue of hiring new researchers, and second, the provision of sufficient incentives to new brainpower returning from abroad to join KRIHS. Actually, his concern was to secure competent researchers for the new institute. There was a request from the MOC to accept as many staff as working at the CTPR, but he insisted that they were not properly trained enough to join the research institute and accepted only a small number of staff through screening measures. More important was the provision of adequate incentives for PhD holders from prestigious foreign universities to strengthen the research capacity of the institute. Regarding this issue, there was a consensus with the MOC, which was to follow the previous practices of KDI. ${ }^{3}$

The first three professionals recruited from US universities at KRIHS were Seong Ung Hong (economist, the former president of the Construction Economy Research Institute), Soo Young Park (urban planning, the former president of the Gyeongnam Institute) and Won Young Kwon (urban planning, the former president of the Seoul Institute). On recruitment, they were all paid well, with salaries much higher than those of standard university professors at the time, but more importantly, they received abundant extra salary incentives. Particularly, KRIHS provided relocation expenses and free housing for foreign university PhD holders.

The most attractive [incentive] was an apartment unit of approximately $100 \mathrm{~m}^{2}$ free of charge. There were not many apartments in Seoul back then. It looked so modern and state-of-the-art that all my relatives came to see my new apartment. At the time, KRIHS maintained around 30 units of apartments supported by major construction companies in Korea. ${ }^{4}$

It should be noted that KRIHS was only a part of the government's aggressive drive for returning scientists and intellectuals to Korea. In the 1960s, Korea, like many other Asian countries, had a serious brain drain problem. According to the Ministry of Education (MOE), 90 percent of Koreans who studied in the United States chose to remain after earning a doctoral degree (Yoon, 1992). It was not surprising because there were not enough employment opportunities at home for American-educated Koreans. The government's systematic repatriation effort began in 1966 when KIST, a multidisciplinary R\&D institute for industrial technology, started to recruit a group of senior-level scientists and engineers from America and West Germany. Early Korean PRIs were all a part of this movement. The Korean government's repatriation efforts were highly concentrated in the recruitment of high-level professionals, particularly in the public sector R\&D institutes (Lee, Bae and Lee, 1991). Referred to as a 'reverse brain drain' by Yoon (Yoon, 1992), the government's efforts were highly successful. Since the early 
1980s, the private sector has also been aggressively pursuing this model of the state-led repatriation program.

In a nutshell, the Korean PRI system was the result of the Korean government's organized efforts to recruit high-level scientists and intellectuals educated abroad. The knowledge production market in the private sector was so underdeveloped that the government decided to develop a government-nurtured knowledge production system. The PRIs, including KRIHS, became channels through which the nation could secure high-level professionals in a more stable manner.

\section{Government-institute relations}

The relationship between the government and PRIs has been a tricky issue since the beginning of PRIs. There are two conflicting arguments regarding the issue of the independence of PRIs. The first is the view that the PRIs should be under the control of the government because their raison d'être is to support the government with policy research and advice. In light of their roles given, building an intense partnership with and paying attention to demands from the government are important not only for the government but also for the PRIs themselves. The other argument is that the PRIs should be independent because they need to provide various alternative views on contentious social issues regardless of the government's stance. If the PRIs are just repeating the government's position, they would lose their reputation as research institutes and most likely their social roles. These two conflicting arguments demonstrate the inherent difficulties that the current government-led PRI system faces.

This issue became more problematic as Korea went through political democratization since the 1990s. Under the authoritarian rule in the 1970s and 1980s, the central government had undisputed power and single-mindedly pursued an unchallengeable goal, the so-called "modernization of the fatherland". There was no dispute regarding the social role of the PRIs under the circumstance. With the arrival of democratization, however, the influence of the central government eroded significantly and social values on various policy issues became diversified and ended up competing against each other. In particular, as conservative governments and liberal governments took office in turn from the 1990s, the PRIs often confronted embarrassing moments in which they had to negate their own achievements made under the previous government with a different ideological stance.

For example, after the Lee Myeong Bak administration took office in 2008, the importance of the previous government's pet projects was significantly downgraded. The new government tried to downplay and defund the previous Roh Moo-hyun administration's key territorial policies, such as the National Balanced Development Initiative and the New Administrative City construction project, on the grounds that they were not aligned with the philosophy of the new government. It was embarrassing for KRIHS, as a designer of these projects, to have to negate its own achievements during the previous government. Something similar happened again when another new government, the Park Geun-hye 
administration, came to office in 2013. The new government tried to erase the shadow of the green growth strategy, Lee Myeong Bak administration's pet project, as the new government found its own policy narratives. Consequently, political democratization made the relationship between the government and the PRIs more complicated.

The changing circumstances have been reflected in the governance structure of the PRIs. When the PRIs were established, all institutes were based on individual laws and financed directly by their respective ministries. They had each built a close relationship with a particular individual ministry, but at the same time, the independence of the PRIs in research and management was limited. Responding to the changing circumstances brought by democratization, the central government introduced the NRC as a governing body with an integrated legal system, and brought all PRIs under the NRC. ${ }^{5}$

KRIHS as well was launched by the "KRIHS Promotion Act" in 1978 with financial support from the MOC. KRIHS was legally independent in that the president of KRIHS was responsible for the management of the institute, including the matter of hiring researchers. However, the MOC had reviewed KRIHS's management plan and provided its annual budget, so it was hard for researchers at KRIHS to express different views from the MOC's official position. With the establishment of the NRC, KRIHS's management, along with other PRIs, has been reviewed, funded and evaluated by the NRC. Still, KRIHS works closely with the MOLIT (the successor of the MOC) in research activities, but it is governed by the NRC, separate from the MOLIT (see Table 12.3).

It is not fair to say that this measure transformed KRIHS into a completely independent organization free from the political and administrative influence of the MOLIT. Still, one-third of KRIHS's budget comes from the central government through the NRC, and all the key contents that KRIHS is producing pertain to the national policies that the MOLIT takes initiative of. Yet, it is also true that the MOLIT is not in a position to direct the management of the institute, and KRIHS undertakes the MOLIT's research only by contract with the MOLIT's separate budget. ${ }^{6}$ Today, KRIHS researchers are keen on the MOLIT's policy demands, but they try to suggest future directions based on fact-finding surveys and analyses, rather than just following the government's position (see Figure 12.1).

Table 12.3 Changes in the governance of KRIHS

\begin{tabular}{lll}
\hline Category & $1978-1999$ & 1999-present \\
\hline Law & KRIHS & Act on the Establishment, Operation and \\
& Promotion Act & Fostering of Government-Funded Research \\
Institutes, etc. & National Research Council for Economics, \\
Governing & The Ministry of & Construction \\
Budget Source & The Ministry of \\
Construction & National Research Council for Economics, \\
& Humanities and Social Science (NRC) \\
\hline
\end{tabular}




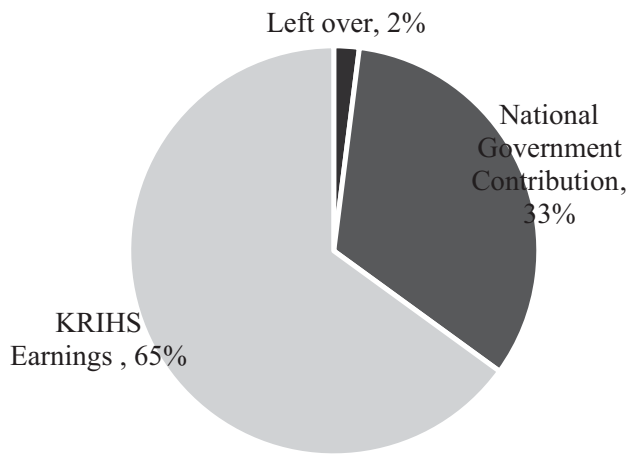

- Left over - National Government Contribution $\quad$ KRIHS Earnings

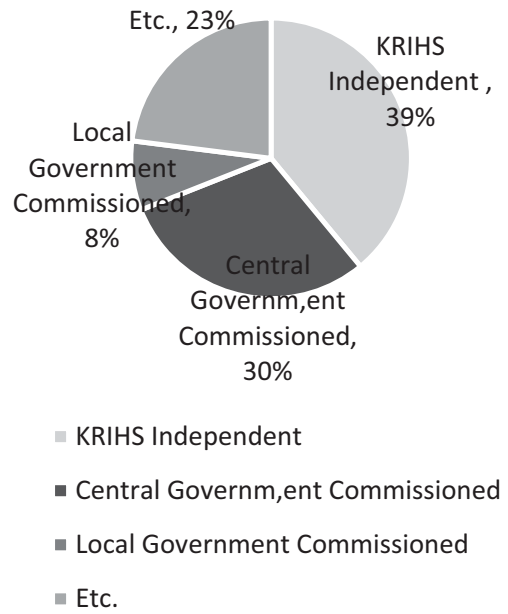

Figure 12.1 Composition of KRIHS budget (2017) by source (left) and the types of research projects between 2009 and 2018 (right).

For the government side on the other hand, providing a certain level of independence was instrumental for the effective utilization of the PRIs, which are under an increasingly competitive knowledge production environment. In the 1990s, the employment market for professionals was dramatically improved so that the PRIs were in competition with universities and other private research institutes. Without a certain level of independence, it is hard for the PRIs to maintain the good reputations that they had enjoyed in the past. In addition, the policy advice of independent but well-coordinated institutes is required for the government to 


\section{Se Hoon Park}

justify increasingly politicized policy issues. Consequently, it can be said that this subtle governance was the result of an interdependent relationship between the government and the PRIs.

\section{State-led urban development regime}

In the urban development field, the role of the PRIs, particularly KRIHS, has been crucial for national policymaking and implementation. Most large-scale national development projects have been designed and/or reviewed by KRIHS, and implemented by various public agencies in coordination with the MOLIT. This is not necessarily because KRIHS has been one of the top research institutes in this field. Rather, the reason lies in the fact that KRIHS has been an integral part of the state-led urban development regime.

Korea's urban and regional development has been shaped by the national government's rule setting efforts since the 1960s. To respond to the unprecedented pace of urbanization and the ensuing urban problems, the national government had introduced various rules and regulations on urban planning and development. Particularly, the national government's efforts had focused on building the legal and institutional grounds for speedy and efficient land development. Under the rapid pace of urbanization throughout the 1960s to the 1990s, urban land for housing, industries and infrastructure was in constant shortage. Urban development laws were introduced to ensure speedy land development, and the role of public agencies involved in land development activities such as land value appraisals, land measurement and design/development have been strengthened. In these urban regulations, the interests of local government and individual land owners were largely side-lined under the name of "public interest". New towns and industrial complexes across the nation today are the product of the state-led urban development.

It should be noted that in this regime for "speedy land development", public agencies such as research institutes and public corporations have been playing important roles. When the MOLIT or the presidential office initiates a national project, public agencies participate in the project in a systematic way to support the achievement of the policy goals. While KRIHS undertakes the role of policy design and communication with academic circles, public corporations such as the Korea Land and Housing Corporation ( $\mathrm{LH}$ ) and Korea Water Resources Development Corporation (K-Water) join the project by taking the role of the actual implementation on the ground. Private construction companies also become partners by participating in development projects commissioned by public corporations. In a nutshell, the Korean urban development regime has a wellcoordinated hierarchical structure created by the interdependence of the government and public agencies to cope with rapid urbanization in the high economic growth era. With the increased voices of local governments in the 1990s, this regime has been pursued by local governments that have been keen on expediting land development in their jurisdictions. In this regard, "local urban development regimes" have been formulated by the partnerships between local governments, 
local research institutes and local development corporations. For instance, the Seoul Metropolitan Government established the Seoul Institute as its think tank, and operates $\mathrm{SH}$ corporation as a policy implementer, just like the relationship between the MOLIT, KRIHS and LH at the central government level.

The Multifunctional Administrative City (MAC) construction showcases how the Korean urban development regime works. ${ }^{7}$ The MAC Construction Project, one of the largest urban development projects in Korea, started in 2003 as a part of the national balanced development policy. Now the MAC houses three-fourths of the central government functions and most of the PRIs and is still under construction, with the target of accommodating 500,000 people (The National Agency for Administrative City Construction, 2008). When the construction project was first conceived in 2002, the decision-makers in the MOLIT and the presidential office had the mobilization of the existing regime in mind.

Initially, the authority established the National Agency for MAC Construction Committee as a top-level decision-making body consisting of government officials and private experts. This organization undertook the role of reviewing and deciding all the important matters, from site selection and the master plan to the government agency relocation plan. At a practical level, the government, research institutes and public corporations were working together in a coordinated way. First, the MOLIT provided the arrangement of key players and the work scope surrounding the project, and research institutes, public corporations and local governments found their roles in the given work frame. Here, KRIHS, among many other research institutes that participated with their own expertise, played a crucial role in spearheading major issues of the project, from conceptual design and site selection to the master plan. Also, LH installed the special team in the organization to support the government plan, and played a pivotal role as a land developer and policy implementer. This coordinated work among different organizations was possible because they had shared organizational interests and had built partnerships through repetitive experiences of previous national urban development projects. Without the concerted efforts of these organizations, that is, the functioning of the regime, the MAC would have not been constructed in such a speedy way (see Table 12.4).

In this light, the role of KRIHS has been enhanced as it has repeatedly demonstrated its utility value within the regime. Therefore, the question of how long KRIHS will continue its social role is something to do with the matter of the survival and dismantlement of this regime in the future. In recent years, there have been signs of the dismantlement of the regime as urban development becomes no longer a lucrative business for the government and the private sector. Yet, this does not directly lead to the demise of the regime. Rather, it is being discussed that the role of KIRHS should be expanded, with a particular focus on building partnerships with emerging players such as local governments, civil society and small businesses. In the end, however, with the termination of "the era of development", it is highly likely that KRIHS faces a difficult situation in which it has to find a new role outside of the urban development regime. 
Table 12.4 Roles of actors in the MAC Construction Project

\begin{tabular}{|c|c|c|c|}
\hline $\begin{array}{l}\text { The National } \\
\text { Agency for MAC } \\
\text { Construction } \\
\text { Committee }\end{array}$ & $\begin{array}{l}\text { Presidential } \\
\text { Office }\end{array}$ & $\begin{array}{l}\text { Decision-making } \\
\text { on key issues }\end{array}$ & $\begin{array}{l}\text { Review and decision on the } \\
\text { matters of: } \\
\text { Site selection } \\
\text { Basic master plan } \\
\text { Relocation plan } \\
\text { Designation of the project } \\
\text { manager, etc. }\end{array}$ \\
\hline $\begin{array}{l}\text { The National } \\
\text { Agency for MAC } \\
\text { Construction } \\
\text { Support Team }\end{array}$ & $\begin{array}{l}\text { The MOLIT } \\
\text { and other } \\
\text { ministries }\end{array}$ & $\begin{array}{l}\text { Administrative } \\
\text { works for the } \\
\text { construction }\end{array}$ & $\begin{array}{l}\text { Administrative and } \\
\text { supporting work for the } \\
\text { activities of the committee }\end{array}$ \\
\hline $\begin{array}{l}\text { The MAC } \\
\text { Construction } \\
\text { Research Team }\end{array}$ & $\begin{array}{l}\text { KRIHS and } \\
\text { other PRIs }\end{array}$ & $\begin{array}{l}\text { Policy design and } \\
\text { research }\end{array}$ & $\begin{array}{l}\text { Conducting assigned } \\
\text { research and providing } \\
\text { background information, } \\
\text { including site selection } \\
\text { and master plan/Building } \\
\text { consensus among } \\
\text { academics and the public }\end{array}$ \\
\hline $\begin{array}{l}\text { The MAC } \\
\text { Construction } \\
\text { Project } \\
\text { Management } \\
\text { Team }\end{array}$ & $\begin{array}{l}\text { LH and other } \\
\text { public } \\
\text { corporations }\end{array}$ & $\begin{array}{l}\text { Policy } \\
\quad \text { implementation }\end{array}$ & $\begin{array}{l}\text { All work related to the } \\
\text { physical construction } \\
\text { of the city, including } \\
\text { compensation, finance and } \\
\text { construction }\end{array}$ \\
\hline
\end{tabular}

\section{Conclusion}

The PRIs in Korea are the reflection of the unique Korean development experiences in many ways. They are a part of the government-sponsored knowledge production system, and also the result of the government's nation-building strategy. Under the circumstances in which the knowledge production capacity in the private sector was by far insufficient in the 1960s and 1970s, the PRIs became tools to secure highly educated professionals and build the knowledge production system, both of which were critically required for the nation's industrialization drive. Once the PRIs had been settled in the 1990s, the Korean government tried to keep the system effective even under a liberal and democratic political environment, by modifying the governance structure and providing a certain degree of "independence" in management. The urban development regime, as discussed above, illustrates how and why the PRI system functions well as a tool for the national government's policy development and implementation.

Still, the knowledge production capacity in the private sector in Korea is by far insufficient to meet the research demand for the government's policy development. Private and public universities have grown enormously in number and size in the past six decades, but their research has been mostly focused on academic knowledge that is not easily transferable to policy development. Without the PRIs, 
Korea's knowledge production market and policy development practice would have been very different from what we see today. In this regard, it is fair to say that the government's effort to establish and manage the PRIs has clearly paid off.

What, then, are the lessons that we can learn from the Korean PRIs, particularly when it comes to development cooperation with developing countries? Can we apply the Korean PRI system to developing countries that have been suffering from deficiencies in policy knowledge production? The importance of capacity building and knowledge production has been increasingly recognized in the world of international aid. Particularly, after the Paris Declaration (2005), the ownership of recipient countries became more critical than ever for improving aid effectiveness.

One key lesson from the Korean PRI experience is the fact that knowledge, particularly knowledge for policy development, is critical for economic and social development, and the government can actually build and manage the knowledge production system. The PRIs' contributions to the economic and social development of Korea are quite clear. At first, the PRIs had been established with aid from US-initiated technical cooperation and became the essential channel to promote "reverse brain drain". They took decisive roles in designing national development strategies such as, among others, the first Five-Year Economic Development Plan in 1962 and the first Comprehensive National Territorial Plan (1972), which have paved the way for industrial breakthroughs in subsequent years. Consequently, the PRIs in Korea have enhanced the capacity of decision-makers and social leaders to the extent that they could orchestrate their own projects for economic development with much stronger ownership (Kim, T., 2014).

On the other hand, it is also clear that transferring this system to developing countries is neither simple nor appropriate in more cases than not. As discussed, the PRIs in Korea are not simply think tanks functioning in an independent manner but an integral part of the institutional arrangement for the nation's economic and social development, or in other words, the "developmental regime". They can work only under the circumstance of strong central government leadership, and particular institutional and legal arrangements. Obviously, most developing countries have different state structures and are in different social and economic environments. Weak governments, fragmented and patrimonial social structures, and the neoliberal economic environment are the challenges that many developing countries are currently facing (Igbafen, 2014; E. M. Kim, 2014). That is why we need creative "translation" when it comes to applying the Korean experience to today's developing countries.

\section{Notes}

1 A policy research institute is often called a "think tank", so these two terms are used interchangeably in this chapter.

2 I use the term "regime" to mean "an informal yet relatively stable group with access to institutional resources that enable it to have a sustained role in making governing decisions", in accordance with Clarence Stone's work (Stone, 1993). 


\section{Se Hoon Park}

3 I acquired much of the information in this session from an interview with Dr. Won Young Kwon (February 8, 2019).

4 Interview with Dr. Won Young Kwon on February 8, 2019.

5 It is said that the NRC benchmarked the Research Council system in the UK. The UK operates the seven Research Councils as governing bodies for public research institutes under the Department for Business Innovation and Skills. The UK system has been known for the Haldane principle under which the government provides financial support but does not intervene in the management of research institutes (Kim, 2012). When the NRC was introduced, there were three official reasons offered by the government for the governance change: to provide independence in management and research, to evaluate the PRIs more efficiently and to promote collaborative research among PRIs (Maeil Economy Daily, December 9, 1998).

6 These are the project-based contracts in which the MOLIT requests research projects to KRIHS, separate from the central government's annual financial support for general management. Currently, around 30 percent of research projects are those commissioned by the central government to KRIHS.

7 At first, the MAC Construction Project started in 2003 under a different title, the "New Capital Construction Project", with a view to relocate the capital from Seoul to the new city. After the project was judged as unconstitutional by the Supreme Court in 2004, the government modified the plan, and resumed it in the current form of the MAC. Here, I omitted the details to avoid unnecessary confusion.

\section{References}

Amsden, A. H. (1989). Asia's Next Giant: South Korea and Late Industrialization. New York: Oxford University Press.

Igbafen, M. L. (2014). “South Korea's Development Experience as an Aid Recipient: Lessons for Sub-Saharan Africa," in K. E. Mee and P. H. Kim (eds.), The South Korean Development Experience: Beyond Aid. New York: Palgrave Macmillan, pp. 111-135.

Johnson, C. (1982). MITI and the Japanese Miracle. Stanford, CA: Stanford University Press.

Karthik, N., M. Enrique and D. Ajoy (2010). Think Tanks in East and Southeast Asia: Bringing Politics Back into the Picture. London: Overseas Development Institute.

Kim, B. C. (2012). "An International Comparative Study on the Operating System of the Policy Research Institutes," Journal of Policy Development 12(2), pp. 37-64 (in Korean).

Kim, D. E and K. H. Kim (2014). Think Tanks of Korea: Contributions to Economic Development and Their Evolution. Sejong: Knowledge Sharing Program Report, Ministry of Strategy and Finance.

Kim, E. M. (2014). "Conclusion: Beyond Aid," in E. M. Kim, and P. H. Kim (eds.), The South Korean Development Experience: Beyond Aid. New York: Palgrave Macmillan, pp. 172-182.

Kim, H. K., K. W. Shin, C.-G. kang, W.-S. Moon, M.-H. Park, S. H. Park, J.-Y. Lee, B. Thole, J.-S. Lee, T.-H. Lim and J.-Y. Kim (2009). Think Tanks of Five Countries. Sejong: National Research Council for Economics, Humanities and Social Science (in Korean).

Kim, T. (2014). "Learning through Localizing International Transfers: South Korea's Development Experiences," in I. Yi and T. Mkandawire (eds.), Learning from the South Korean Developmental Success: Effective Developmental Cooperation and Synergistic Institutions and Policies. London: Palgrave Macmillan, pp. 216-234. 
KRIHS (1983). 5 Years History of Korea Research Institute for Human Settlements. Sejong: KRIHS (in Korean).

Lee, D. H., Z. Bae and J. Lee (1991). "Performance and Adaptive Roles of the Government-Supported Research Institute in South Korea," World Development 10(10), pp. 1421-1440.

Mo, J. (2005). Think Tanks and Good Governance: The KDI Story. HGCY Working Paper Series No. 05-04. Seoul: Hills Governance Center, Yonsei University.

The National Agency Administrative City Construction (2008). White Paper on the Multi-functional Administrative City, 2003-2007. Sejong: The National Agency Administrative City Construction.

Rich, A. (2004). Think Tanks, Public Policy, and the Politics of Expertise, Cambridge: Cambridge University Press.

Stone, C. (1993). "Urban Regimes and the Capacity to Govern: A Political Economy Approach," Journal of Urban Affairs 15, pp. 1-28.

Stone, D. (1996). Capturing the Political Imagination, Think Tanks and the Political Process, London: Frank Cass.

Um, K. C. (1993). "The Root of KRIHS, from UPI to KRIHS," Monthly News February 1993, pp. 5-10 (in Korean).

Weaver, R. K. (1989). "The Changing World of Think Tanks," Political Science and Politics 22(3), pp. 563-578.

Woo-Cumings, M. (1999). "Introduction: Chalmers Johnson and the Politics of Nationalism and Development," in M. Woo-Cumings (ed.), The Developmental State. Ithaca, NY: Cornell University Press.

Yoon, B.-S. L. (1992). "Reverse Brain Drain in South Korea: State-led Model," Studies in Comparative International Development 27(1), pp. 4-26. 


\title{
13 Engines for development Public development corporations and their role in urban development in Korea
}

\author{
Jieun Kim
}

\section{Introduction}

Urbanization in Korea cannot be fully understood without an account of public development corporations (PDCs), and vice versa. Major national PDCs were born in the 1960s and 1970s, the era of state-driven economic development. They were responsible for supporting industrialization by expanding and operating urban infrastructure with limited state funding. For their own survival, PDCs had to actively seek profitable business opportunities from the early days. One of the most profitable was the land development project. The pursuit of land development was legitimized on the ground that it would eventually contribute to the public welfare. This works as valid logic to this day.

This chapter defines PDCs as state-owned enterprises, ${ }^{1}$ responsible for developing and operating key urban infrastructure for the public interest. As of 2019, there were 30 national PDCs and 48 local PDCs in Korea. National PDCs are governed by the Act on the Management of Public Institutions, which regulates matters concerning national public institutions. Of the 339 national public institutions governed by this law, those that have more than 50 regular employees and 50 percent of self-generated revenue are defined as national public enterprises. According to these criteria, there are 36 national public enterprises; 30 of them are considered PDCs, as their main tasks entail developing and operating urban infrastructure such as electric power, water resources, roads, railways, housing and so on. Meanwhile, local PDCs are governed by the Local Public Enterprises Act. There are 405 local public enterprises controlled by this law, of which 48 could be considered as PDCs; the others are mainly engaged in the operation and maintenance of public facilities or promotion of local products. Local PDCs appeared after the late 1980s as local governments sought to respond to the Two Million Housing Plan. In any case, PDCs are supposed to pursue both commercial and social goals (see Table 13.1).

As key partners of the developmental state, PDCs have been granted exclusive authority to undertake the development of land, urban infrastructure and affordable housing. Based on this authority, PDCs have established themselves as key members of the urban growth coalition in Korea. Most PDCs used 
Table 13.1 Legal basis for PDCs

\begin{tabular}{|c|c|}
\hline Controlling law & Examples \\
\hline (National PDCs) & Korea Electric Power Corporation (KEPCO) \\
\hline $\begin{array}{l}\text { Act on the Management of Public } \\
\text { Institutions }\end{array}$ & $\begin{array}{l}\text { Korea Water Resources Corporation } \\
\text { (K-Water) }\end{array}$ \\
\hline —Public institutions that have more & Korea Land and Housing Corporation ( $\mathrm{LH})$ \\
\hline $\begin{array}{l}\text { than } 50 \text { regular employees and } 50 \% \text { of } \\
\text { self-generated revenue }\end{array}$ & Korea Expressway Corporation (KEC) \\
\hline \multirow{7}{*}{$\begin{array}{l}\text { (Local PDCs) } \\
\text { Local Public Enterprises Act } \\
\text { - No specific criteria to define PDCs } \\
\text { other than majority ownership } \\
\text { requirement and permitted business } \\
\text { sectors (e.g. water, sewerage, local } \\
\text { roads, housing, etc.) }\end{array}$} & Seoul Housing and Communities \\
\hline & Corporation $(\mathrm{SH})$ \\
\hline & Incheon Metropolitan City Development \\
\hline & Corporation (IMCD) \\
\hline & Gyeonggi Urban Innovation \\
\hline & Corporation (GUIC) \\
\hline & Busan Metropolitan Corporation (BMC) \\
\hline
\end{tabular}

to have the word "development" in their company names (e.g. Korea Water Resource Development Corporation, Korea Land Development Corporation, Seoul Urban Development Corporation), today, PDCs have removed "development" from their names because the word is considered to carry a negative connotation of the developmental era. Although "development" disappeared from their names, it is still firmly rooted in their identities. Hong (2005), one of the strong critics of PDCs, noted that the developmental dictatorship is gone, but the developmentalism persists. Furthermore, he argues that Korea's developmental state has transformed into a "construction state" led by politicians, PDCs and the construction industry. Today, the total assets ${ }^{2}$ of the ten biggest PDCs are as large as those of the ten biggest chaebols (See Table 13.2); they became too big to fail.

The prospect of slow economic growth and stagnant domestic demand has forced Korea's urban growth coalition to pioneer new growth engines. One of these is the exportation of the Korean urban development model. Underpinning this is the simple idea that Korea's successful response to the explosive demand for urban development during the rapid urbanization could be replicated in other developing countries. An important but less discussed fact is that the essence of Korea's urban development model lies in the way institutions and actors are mobilized to build cities. To fill the gap, this chapter examines how PDCs became pillars of the Korean urban development model during the highgrowth era, how their roles are changing as Korea enters the low growth era and what implications they offer to developing countries. Among many PDCs in Korea, I will shed light on the particular roles that major national PDCsthe Korea Water Resource Development Corporation (K-Water), the Korea Housing Corporation and the Korea Land Corporation in particular-have played in shaping Korean cities. 
Table 13.2 Total assets of Top 10 chaebols and Top 10 PDCs $(2015)^{\mathrm{a}}$

\begin{tabular}{|c|c|c|c|c|}
\hline Rank & Chaebol & $\begin{array}{l}\text { Total Assets } \\
\text { (KRW } \\
\text { trillion) }\end{array}$ & $P D C$ & $\begin{array}{l}\text { Total Assets } \\
\text { (KRW } \\
\text { trillion) }\end{array}$ \\
\hline 1 & Samsung Electronics & 169 & $\begin{array}{l}\text { Korea Land and Housing } \\
\text { Corporation }\end{array}$ & 170 \\
\hline 2 & $\begin{array}{l}\text { Hyundai Motor } \\
\text { Company }\end{array}$ & 67 & $\begin{array}{l}\text { Korea Electric Power } \\
\text { Corporation }\end{array}$ & 106 \\
\hline 3 & POSCO & 51 & Korea Expressway Corporation & 58 \\
\hline 4 & Samsung C\&T & 34 & $\begin{array}{l}\text { Korea Hydro \& Nuclear } \\
\text { Power }\end{array}$ & 51 \\
\hline 5 & Kia Motors & 34 & Korea Gas Corporation & 40 \\
\hline 6 & $\begin{array}{l}\text { Hyundai Heavy } \\
\text { Industries }\end{array}$ & 30 & K-Water & 19 \\
\hline 7 & Hyundai Steel & 30 & Korail & 18 \\
\hline 8 & SK Hynix & 29 & $\begin{array}{l}\text { Korea National Oil } \\
\text { Corporation }\end{array}$ & 17 \\
\hline 9 & Lotte Shopping & 26 & $\begin{array}{l}\text { Incheon International Airport } \\
\text { Corporation }\end{array}$ & 9 \\
\hline 10 & LG Electronics & 25 & Korea South-East Power Co. & 9 \\
\hline Top 10 & Chaebol Total & 496 & Top 10 PDC Total & 498 \\
\hline
\end{tabular}

${ }^{a} \operatorname{Kim}(2017)$.

\section{PDCs in the high-growth era}

The expansion of social overhead capital is a common challenge for developing countries with limited financial resources. Korea was in the same situation when the developmental state launched the First Five-Year Economic Development Plan in the 1960s. Newly established PDCs were required to develop and operate large-scale infrastructure with little operation funds from the state. To overcome the lack of funding, PDCs started taking advantage of urban development projects from the early days. Land development, in particular, has been a promising business because of the acute shortage of land for housing, manufacturing and more. Naturally, PDCs actively sought land development opportunities, which were often created by their own infrastructure projects.

\section{Ripple effect of $K$-Water's land reclamation business}

One of the first PDCs that entered the land development business was K-Water. K-Water initiated land reclamation projects as early as 1968. Established in 1967, its main task included research of major river basins, supervision of water resource development projects, and operation of multi-purpose dams. K-Water started with a capital of KRW 3.6 billion, of which the cash contribution was only KRW 50 million. $^{3}$ Its first task, the Soyang Dam (1967-1973), still the fourth largest embankment dam in the world, was estimated to cost more than KRW 30 
billion. ${ }^{4}$ Back in 1967, Korea's national budget was just over KRW 164 billion. Obviously, the Soyang Dam was the state's top priority project, as it would solve multiple issues at once: reduce flood risks along the Han River Basin, satisfy almost half the water demand of the Seoul Metropolitan Area and generate 353 GWh/year ${ }^{5}$ of electricity. As a newly established, scarcely funded PDC, K-Water needed to find profitable business opportunities in order to carry out its mission and sustain itself.

As the Soyang Dam was built upstream of the Han River, K-Water expected that there would be less flood risk downstream. That meant that the once flood-prone areas along the Han River would become habitable. So, K-Water decided to initiate the Seobinggo Land Reclamation Project on the north side of the Han River. In 1968, K-Water obtained the land reclamation license from the Ministry of Land, Infrastructure and Transport and took loans from the Housing and Commercial Bank. ${ }^{6}$ Between 1969 and 1970, the reclaimed land was sold to the Korea Housing Corporation and private construction companies, generating a net profit of KRW 1.7 billion to K-Water. Soon thereafter, industrial park development, which generally entailed land reclamation and water resource development, also became K-Water's key business. Since then, land reclamation and industrial park development have been K-Water's priority businesses.

The Seobinggo Reclamation Project had ramifications beyond K-Water. First, the state was able to expand land supply just by granting land reclamation permits. By having profit-making PDCs, the state became able to build urban infrastructure and industrial parks with minimum financial contributions. Second, in anticipation of the high profit margin, private construction companies started competing for land reclamation projects along the Han River. The state strategically rewarded companies that contributed to its priority projects by allocating land reclamation permits. Hyundai Engineering \& Construction was the case in point. Hyundai pleased the state by successfully constructing the Soyang Dam at lower costs than expected. In return, the state granted land reclamation permits for Apgujeong and Banpo ${ }^{7}$ to Hyundai and its consortiums. As such, K-Water's survival strategy contributed to strengthening Korea's burgeoning urban growth coalition (see Figure 13.1).

\section{The Korea Housing Corporation: creating the high-rise lifestyle}

The Korea Housing Corporation (KHC) was one of the low-priority PDCs when it was established in 1962. As indicated by its name, the KHC's main mission was to expand housing supply. Despite the high demand for housing, the KHC struggled throughout the 1960s due to the lack of funding and proper business models. According to the Act on Public Housing of 1963, the state may provide funding for the $\mathrm{KHC}$ and local governments ${ }^{8}$ to expand affordable housing supply. In reality, however, the state prioritized industrial development over housing when allocating its budget. For example, the state was supposed to provide KRW 1 billion in capital investment, but the KHC only received in-kind 


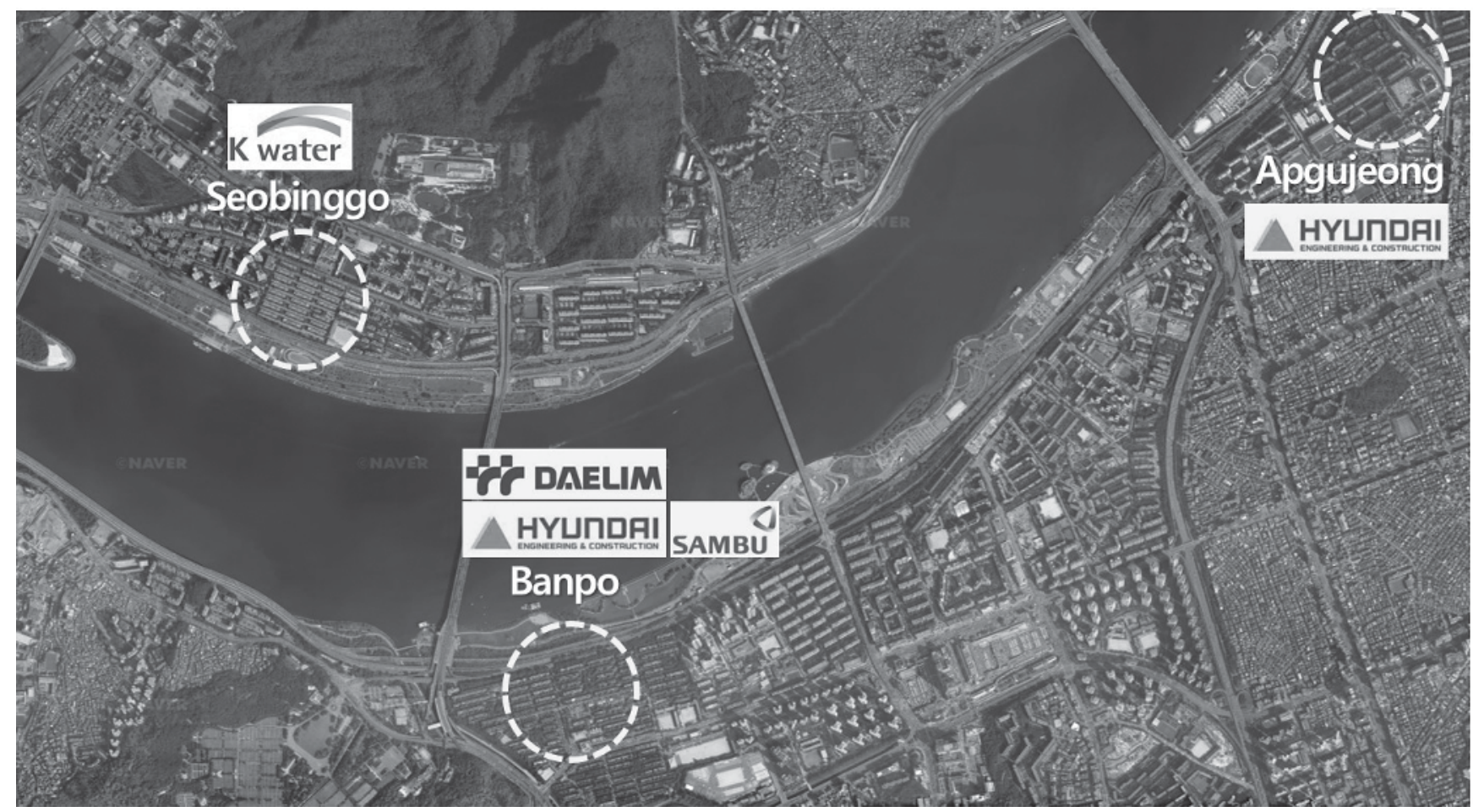

Figure 13.1 Location of land reclamation projects. 
contribution of less than KRW 500 million by 1967. So, the KHC needed to find profitable projects for its own survival.

The 1960s was a time when the KHC experimented with the marketability of apartment neighborhoods. The housing supply rate in the mid-1960s was below 50 percent. So, the KHC's target population was not limited to low-income families. In the early days, the KHC built apartments for middle-income families or foreigners who could afford pricy apartments with modern designs and equipment. ${ }^{9}$ It was an inevitable choice for the $\mathrm{KHC}$, but the public was critical of the KHC's profit-oriented business direction. One of the most controversial projects was the Hangang Mansion, an apartment complex built on the reclaimed land of Seobinggo, which the KHC had purchased from K-Water. In 1969, more than 60 percent of the KHC's total investment went into the Hangang Mansion Project. Targeting the middle- and high-income families, the Hangang Mansion offered spacious housing units ranging from 88 to 180 square meters with the first central heating system in Korea. It was a profitable project, but the $\mathrm{KHC}$ was heavily criticized for neglecting the housing needs of working families.

The KHC's Hangang Mansion Project played a critical role in shaping the direction of the Korean housing industry. It is said that the president of Hyundai Engineering \& Construction, Ju-Young Jung, came to realize that apartments could be a money-making business as he witnessed the successful sales of the Hangang Mansion. ${ }^{10}$ From then on, both private construction companies and the KHC were eager to enter the apartment business. As apartments for the middle-class were successful, more people began to recognize apartment living as a preferable lifestyle.

For the state, apartments became a valuable means of managing political risks. The 2.5 Million Housing Plan of 1972, the Five Million Housing Plan of 1980 and the Two Million Housing Plan of 1989 all aimed to ease the growing social discontent against the state. To achieve the massive housing supply plan, the state mobilized both the PDCs and private construction companies. The key to success was whether they could secure enough land to build apartments. So, a series of supporting mechanisms was introduced in the mid-1970s. First, the state added a clause to the Land Compartmentalization and Rearrangement Projects Act allowing it to ask developers to devote a portion of land for apartment projects (1975). Second, the Apartment District, which would be solely dedicated to apartment construction, was introduced to the Urban Planning Act (1976). Last, the state allowed the KHC to exercise eminent domain for the purpose of mass housing supply (1977). Thanks to the growing popularity of apartments and the institutional support, the KHC's housing supply in the 1970s became 16 times more than that of the 1960s. Today, apartments accounts for more than 60 percent of housing stock, up from 2 percent in 1975.

\section{Capturing development gains via the Kovea Land Development Corporation}

Between 1963 and 1970, land prices in Seoul increased by 17 times on average. This was in part a matter of supply-demand imbalance. However, the state 


\section{Jieun Kim}

found the cause of soaring land prices to be from the land speculation of large corporations. They were purchasing land by diverting the preferential loans, which they were supposed to invest in export-oriented businesses. Although most of them were heavily in debt, they did not let go of their idle land in anticipation of higher returns. To fix this situation, the state created the Land Bank in 1975. The Land Bank aimed to buy idle lands from corporations or individuals, and then sold them to others who would put them to better use. In 1979, the Land Bank became the Korea Land Development Corporation (LDC), a public development corporation specialized in the acquisition, development and supply of land.

From the outset, the LDC's role overlapped with other existing PDCs. K-Water, then named as the Industrial Park Development Corporation, was specialized in the land development for industrial parks and the housing around them. In 1977, K-Water began undertaking a satellite city project, Banwol Industrial New Town. It was the first satellite city project in which a PDC purchased the whole share of land by exercising eminent domain. In 1977, the KHC was also given authority to use compulsory land acquisition for the purpose of housing development. Soon thereafter, the KHC took charge of another satellite city project, the Gwacheon New Town. The 1980 amendment of the Land Compartmentalization and Rearrangement Projects Act specified that the KHC, K-Water and the LDC were eligible to implement land readjustment projects on behalf of local governments. The Housing Site Development Promotion Act, which was enacted in 1980, included both the KHC and the LDC as the implementing agencies. Obviously, there were some overlapping roles among them, but each PDC saw it as an opportunity to diversify its business areas.

Indeed, their business environment was much improved as the Housing Site Development Promotion Act allowed PDCs to take advantage of eminent domain and streamlined permit processes for housing site development projects. The housing site development method had an overwhelming comparative advantage to the land rearrangement method in that the state could capture much of the land development gains via PDCs. In the former method, PDCs buy all the land ownership in the name of the public good. Due to the strong land market, the expected profit margin of any land development project was more than enough to cover the development costs. So, PDCs were able to monopolize land development gains, and the gains were shared with central and local governments in the form of off-budget public projects. Meanwhile, in the case of the land rearrangement method, which does not entail a change of land ownership, the original landowners accrued most of the development gains.

Naturally, the housing site development method started dominating the land market from the 1980s. In the 1960s and 1970s, for example, more than 90 percent of land development was done by the land rearrangement method. Between 1982 and 1986, the share of the housing site development method rose to 64 percent. Having three similar PDCs, the state was able to encourage a loyalty competition among them with the strategic distribution of the public land development projects. Development gains captured by PDCs were used as cross-subsidies for 
the supply of below-market price for-sale housing and public rental housing. The shift to the public land development method also had implications for large private construction companies. Instead of striving to purchase land from individual landlords, they turned to infrastructure-ready housing sites developed and sold by PDCs. In this way, the Korean urban growth coalition strengthened its ties; at the center were those PDCs.

\section{Emergence of new competitors: local PDCs}

The Two Million Housing Plan of 1988, which gave birth to five satellite cities around Seoul, dramatically increased the role and number of PDCs. In order to mobilize local governments for this massive housing supply plan, the Ministry of Land, Infrastructure and Transport made an announcement that local governments may carry out land development projects. The Seoul Metropolitan Government (SMG), which was required to supply 400,000 houses in line with the state's housing supply plan, decided to create its own PDC called the Seoul Urban Development Corporation (SH). The reason why the SMG wanted to have the SH was simple: to take advantage of the development gains of the public land development projects by itself. Before creating the SH, the SMG had to endure long and difficult negotiations with the national PDCs (e.g. the KHC, the LDC) and the Ministry of Land, Infrastructure and Transport in order to make use of development gains from housing site development projects in Seoul. Having its own PDC meant that the SMG came to have direct control over the development gains. Thanks to the SMG's support and the strong land market, the SH grew quickly. When it was established in 1989, its total assets were KRW 260 billion, KRW 85 billion of which was debt and KRW 140 billion capital. In three years, the total assets grew by 7.7 times, and debt and capital by 5 times and 4.5 times, respectively.

The Two Million Housing Plan produced new competitors of the KHC and the LDC. Even so, there seemed to be plenty of development for all of them. By 1992, the state was able to reach the goal of supplying two million houses. That meant an annual supply of 400,000 houses, which was a dramatic expansion from the previous 220,000. Due to the Two Million Housing Plan, the share of construction investment in GDP reached the record high level of 23 in the early 1990s. As both PDCs and the construction industry grew in size and number, the dynamics of urban growth coalition became more complex. Still, the state's policy decision shaped the urban development market most of the time.

PDCs have experienced ups and downs according to the state's land and housing policy directions. In the mid-1990s, for example, the state decided to open land development in the quasi-agricultural zone to private developers. Behind this new policy direction was the construction industry hoping to enter the land development business. So, PDCs lost its monopoly over land supply. In less than a decade, however, the quasi-agricultural zone was discontinued due to the unruly development by the private housing developers. Soon thereafter, the construction industry, which suffered from the aftermath of the 1997 Asian 


\section{Jieun Kim}

financial crisis, started asking the state to initiate the second round of satellite city policy. The sudden rise of housing prices in Seoul justified the state's decision to do so. PDCs had no reason to oppose to the most profitable project. This reaffirms that there exist durable, shared interests among the state, PDCs and the construction industry, which could be packaged as an economic stimulus, housing market stabilization measure, housing welfare policy, balanced development strategy and so on.

\section{Public development corporations in the era of low growth}

\section{K-Water's big loss, construction companies' big gain}

While the developmental state has lost much of its means to manipulate the economy, the state-led development policies still persist for various reasons. As always, PDCs are the state's key partners. However, the state-initiated projects, which used to be profit sources, began to weigh on PDCs. Increasingly, the state sees PDCs as risk-bearing or cost-sharing agencies. The underlying assumption is that PDCs would be able to recoup financial losses by carrying out other development projects as they had been before. The problem is that profitable projects are getting scarce as Korea enters the era of low growth.

The case in point would be President MB Park's Restoration of Four Major River Project (the Four River Project) initiated in 2009. The Four River Project was passed along to K-Water after the Ministry of Land, Infrastructure and Transport failed to find private investors. After five months of negotiations between K-Water and the relevant state departments, K-Water was forced to raise KRW 8 trillion by issuing bonds. The state promised to cover the financial costs, and K-Water was supposed to repay the principle with profits from urban development projects associated with the Four River Project. The Eco Delta City Project, a new town development project initiated by K-Water in 2010, was one of those projects. Later, the Busan Metropolitan Corporation, a local PDC, joined this project. This familiar formula, however, did not work well this time. In the end, K-Water had to write off KRW 4 trillion as a loss in 2015.

There is also concern about the Eco Delta City Project itself. Unlike the fancy title, it is criticized for disrupting valuable migratory bird habitats. The prospect of housing oversupply is also a cause of concern. The Eco Delta City is planned to accommodate 76,000 people at completion; the population of the Gangseo District, in which the project is located, was only 116,702 in 2017. The fact that an old neighborhood in the Gangseo District, located about $10 \mathrm{~km}$ away from the Eco Delta City, was selected as one of 33 Neighborhood Revitalization Projects by the Ministry of Land, Infrastructure and Transport testifies the conflict of policy directions. Regardless, K-Water has to proceed with the Eco Delta Project to avoid another big loss. In 2015, the site preparation and infrastructure installation work began, for which major construction companies have won construction orders. Today, the Eco Delta City Project came to have an even fancier title, the Smart Eco Delta City, as the Ministry of Land, Infrastructure and 
Transport selected part of the Eco Delta City as a Smart City Demonstration Site in 2018. It is too early to know whether the Eco Delta City could help K-Water recoup financial losses from the Four River Project. Meanwhile, civil engineering and construction companies were the sole beneficiaries of the Four River Project. According to the Citizens' Coalition for Economic Justice, the top ten construction companies affiliated with the chaebol groups took 50 percent of the total construction order, or KRW 8.6 trillion, of the Four River Projects.

\section{The merger of the two dinosaurs, the KHC and the LDC}

As economic growth and demand for development slow down, the issue of overlapping functions among PDCs stands out. Each PDC had its own mission and business areas in the beginning. As they sought to diversify their profit sources, K-Water, the KHC, the LDC and local PDCs came to perform similar tasks by the mid-2000s. The state's attempt to restructure PDCs began as early as 1993, when the Two Million Housing Plan was accomplished. At the time, the state tried to decentralize the role of the KHC and the LDC. After a few failed attempts, the KHC and the LDC were merged into the Korea Land and Housing Corporation (LH) in 2009.

Competition between private companies tends to increase efficiency. However, this was not the case for PDCs; their competition often resulted in inefficiency. Local governments, for example, would take advantage of the competition between PDCs in order to build public facilities irrelevant to the project scope. This led to higher project costs. In addition to the over-competition and inefficacy issues, the state had a more important reason to push for the merger between the KHC and the LDC. From the vantage point of the state, it was a matter of reducing its own financial burdens. In the mid-2000s, the state was providing KRW 1 trillion subsidy every year so that the KHC could implement the One Million Public Rental Housing Plan (2003-2012). The cost of operating the public rental housing stock weighed on the KHC's financial health as well. Through the merger of the KHC and the LDC, the state was hoping to substitute the huge subsidy bill with the LDC's development gains. The LDC was reluctant to the merger on the surface, but it also had a reason to accept the merger. The LDC knew that the diminishing demand for land development would threaten its sustainability in the near future.

At the time of merger, both the KHC and the LDC were highly in debt. The debt started to grow rapidly from the mid-2000s, as they competed with each other for the state-initiated development projects-notably, the Second Round Satellite Cities, Innovation Cities, Sejong City and One Million Public Rental Housing. This time, they had a different reason to compete: each of them wanted to have power over the other when they were merged. The fact that the state still needed them to implement all those state-initiated projects allowed the $\mathrm{KHC}$ and the LDC to make irrational choices. In 2005, the total debt of the KHC and the LDC was about KRW 34 trillion. When they were merged in 2009, the total debt was KRW 109 trillion and the debt ratio was over 500 percent. Regardless of the 


\section{Jieun Kim}

grim financial situation, the state urged the LH to raise more debt for another state-led urban development project, the Bogeumjari Housing Project. For the first time, however, the $\mathrm{LH}$ failed to issue a KRW 100 billion bond with a fiveyear maturity due to its excessive debt.

The LH was not the only one in financial trouble. Local PDCs were also suffering from accumulated debts. In 2009, 14 out of 15 were borrowing money just to pay off debts. Born in the heyday of urban growth, local governments and PDCs were used to fail-proof projects. So, they were eager to invest in urban development projects without proper feasibility studies. With the connivance of local governments, local PDCs recklessly increased debt to take part in risky projects. None of them were ready to face the era of low growth.

The state approached PDCs' debt crisis as a matter of proper supervision and governance. So, it started to impose a strict cap on the debt ratio and audit guidelines. The real challenge, the limits of development gain-dependent urban policy in the age of slow growth, has been neglected as the state still considers PDCs as useful and manageable partners. That means PDCs might live through the era of low growth as long as the state needs them (see Figures 13.2 and 13.3).

\section{Exportation of Korea's urban development model}

The blow of the shrinking demand for urban development has different implications for different members of the urban growth coalition. So far, PDCs have managed to survive as loyal partners of the state. Meanwhile, the construction industry has been directly affected by the slowdown in the domestic market. Some of the large construction companies have been tapping overseas markets by themselves, hoping that overseas projects could supplement the shrinking domestic market. Indeed, the chart below shows the complementary relationship between the domestic and overseas construction orders (see Figure 13.4).

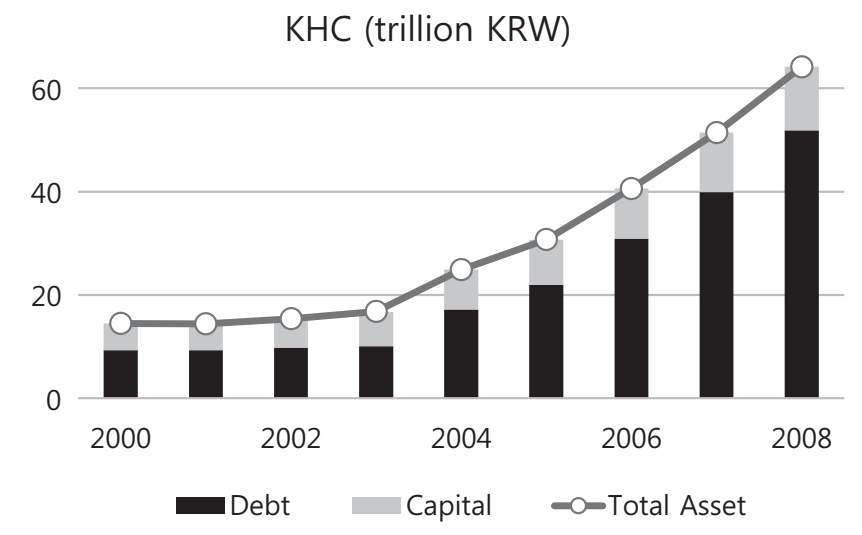

Figure 13.2 KHC debt and capital 1999-2008. 
LDC (trillion KRW)

60

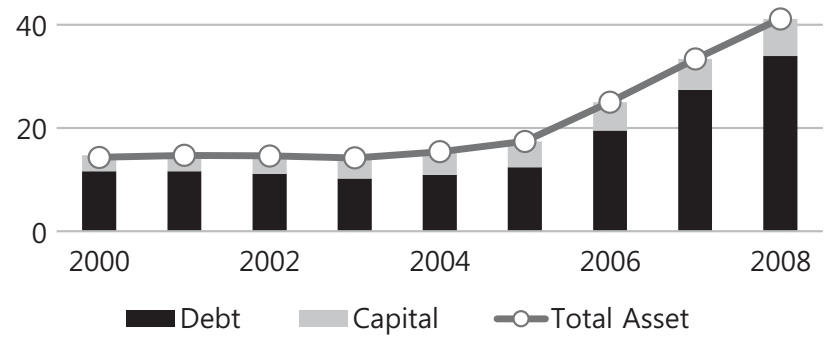

Figure 13.3 LDC debt and capital 1999-2008.

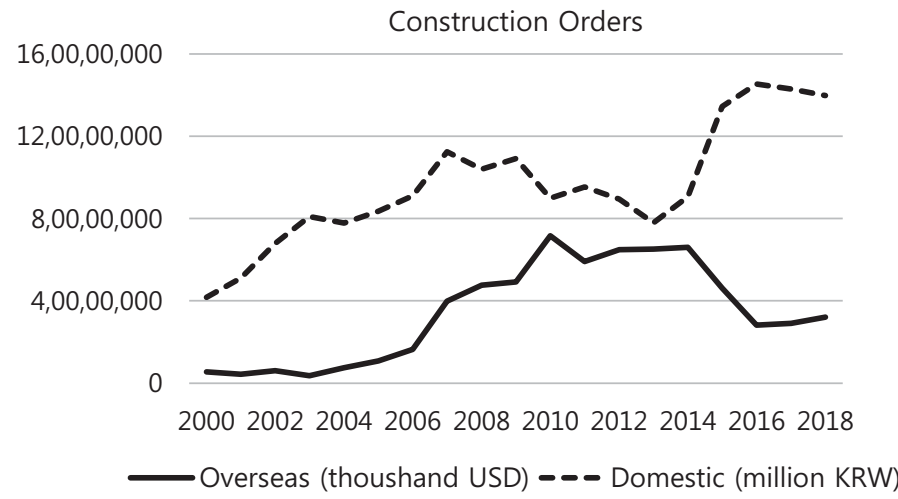

Figure 13.4 Construction orders: domestic vs. overseas.

From the early 2010s, the idea of "city export" started drawing attention. The Samsung Economic Research Institute's report, "City Export: Current Situation and Policy Directions" (2011), triggered discussions on whether the city export could be a new growth engine for Korea. The idea of exporting a city itself had immediate appeal to both the state and the construction industry. Rather than restructuring themselves for the low growth era, they sought to reproduce Korea's new town models - the most profitable product they have known. The state considered that it would be better to create new markets by transferring the Korean model to developing countries rather than pushing unnecessary domestic projects like the Four River Project to keep the urban growth coalition afloat. So, the state was eager to support. The Ministry of Land, Infrastructure and Transport created the Overseas Urban Development Support Center in 2012, 
and entrusted it to the LH. The legacy of state-led export strategy has been revived. From then on, the idea of city export has come and gone like a fashion.

The city export model, on the surface, resembles Korea's new town development projects. But the dynamics among the participating actors are quite different. The most salient difference is in the role of PDCs. There have been a few institutional arrangements that enabled PDCs to play a central role in Korea. First, they are given authority to use eminent domain to take private property for public purposes. Second, they have almost exclusive authority to develop and supply urban land. Third, the state has taken advantage of PDCs as means to capture development gains. In their heyday, PDCs were able to make huge profits by implementing risk-free projects with the state's institutional support. Overseas projects, however, hardly offer those favorable conditions. As PDCs are now under strict debt management, they find it difficult to invest in overseas projects with high uncertainties. With a few exceptions like KEPCO (Korea Electric Power Corporation) and K-Water, ${ }^{11}$ most PDCs have not been able to find proper overseas business models.

The essence of the Korean model does not lie in the physical forms but in the particular institutional arrangement to build cities, and PDCs have been a central part of it. Of course, as I have shown in this chapter, the Korean model has pros and cons. It worked fine during the high-growth period, but now it weighs on society as Korea enters the low growth period. Developing countries have been eager to learn how Korea has responded to rapid urbanization. Without a due account of PDCs, they would be learning only half of the whole story.

\section{Notes}

1 The OECD defines state-owned enterprises as enterprises in which the state has significant control through full, majority or significant minority ownership. In this chapter, the state includes both central and local government.

2 Based on the individual financial statements.

350 Year History of K-Water (2017).

4 The total project cost was KRW 32.1 billion, of which 63 percent was funded by the central government and 37 percent was covered by the war reparations from Japan to Korea.

5 It is supposed to be enough to cover the electricity demand of 330,000 people (50 Year History of K-Water, 2017: 34).

6 The amount of loan from the Housing and Commercial Bank varies by sources. 50 Year History of K-Water (2017) says KRW 105 million; a Maekyung newspaper article (January 28, 1969) says KRW 560 million.

7 Seobinggo, Apgujeong and Banpo are most expensive residential areas to this day.

8 At the time, KHC was required to build public housing for middle-income households (Grade 1 Public Housing), and local governments for low-income households (Grade 2 Public Housing).

9 Dongdaemun Apartment (1965), Jeongdong Apartment (1965) and Hilltop Apartment (1967) to name a few. 
10 "Ju-Seok Roe's Seoul Story: Apartment, Part (1)", Seoul Newspaper (March 10, 2014).

$11 \mathrm{KEPCO}$ and K-Water have been able to enter PPP projects which require equity investment and track records of operation and management in relevant projects. They join forces with construction companies or equipment manufacturers to win competitive bids for mega-infrastructure projects such as power plants, electric grids, hydro dams, and so on.

\section{References}

Ahn, T. H. (2008). "Issues in the Use of Public Development Corporations," Land Development Profits and Policy Directions for Improvement: Focusing on the Korea Land and Housing Corporation, Program \& Policy Evaluation Brief. 22, National Assembly Budget Office.

Hong, S. T. (2005). Public Development Corporations and the Construction State. Paju: Hanul Academy.

K-Water. (2017). 50 Year History of K-Water. Daejeon: K-Water.

Kim, Y. S. (2017). "Analysis of Public Development Corporations' Encroachment of Private Functions and Direction to Improve Neutrality of Market Competition," KERI Insight 17(3), Korea Economic Research Institute.

Korea Housing Corporation (1992). The Thirty Years of Korea Housing Corporation. Seoul: Korea Housing Corporation.

Kwon, N. E., S. J. Kwong and J. H. Lee (2016). "Evaluation of Adequacy of Recent Construction Investment Level," BOK Issue Note 7, The Bank of Korea.

Lee, M. H. (2002). "The Story Behind the Soyang Multipurpose Dam," KSCE Journal of Civil Engineering 50(3), pp. 61-63.

Lim, J. C. (2015). "Experiences of Government-Led Korean New Town Export and Changing Strategies," World \& Cities 5. Seoul Institute, pp. 43-50.

National Assembly Budget Office (2019). Public Institutions of Korea, National Assembly Budget Office.

Seoul Housing \& Communities Corporation (2019). 30 Year History of the Seoul Housing \& Communities Corporations. Seoul: Seoul Housing \& Communities Corporation. 


\section{Index}

Note: Locators in italics refer to figures and those in bold to tables.

administration, pragmatism in, 137-39

Afghanistan, 2

African cities, 58

aid: aid for trade, 2-3; Asian emerging

donors, 103-4; South-South

Development Cooperation (SSDC), 103; urban package of development assistance, 103-5, 105

Bundang, South Korea, 150-57

Central Region (CR), 18-19, 21-23, $23,25,27-28$; policy responses to concentration in, 39-40; regional disparities and, 40-43, 41, 42, 43

China, 2, 103; international urban leadership of, 133; urban development model of $p s$. South Korea and Singapore, 9, 73, 132-40, 142. See also urban development leadership (East Asia)

city export model, 5, 10, 149, 229-30

community engagement, 82 ; grassroots struggles and, 87-93, 88, 90, 92, 94, 95-96; vs. the state, 93-95, 94; transformation of localities and, $87-89,88$

cultural sensitivity, 6

de-concentration policy, 45-47, 52 democratization: neo-developmentalism and, 24-25

developing countries: balanced regional development and, 52; low-income housing policies and, 166, 173, 177-78; new town/smart city development exportation and, 159-61; policy research institutes
(PRIs) and, 215; population growth in, 182. See also Vietnam

Development Assistance Committee

(DAC): OECD/DAC, 2-4, 103

development state in spatial planning

(1960s-80s), 15-20, 16, 19

diplomatic interests, $2-3$

dispersion policies, $47-50$

Eco Delta City Project, 226

economic growth: PDCs in the highgrowth era, 220-26; PDCs in the low-growth era, 226-28; slowing of and urban growth and, 218-19

equity and sustainability, 2, 165; new town developments (Korean model) and, 162; regional development and, $35,50,52-53$. See also regional disparities

evictions, 67, 87-88, 88, 94, 170, 172, 175. See also housing and real estate

financial crisis (1997), 42

form, pragmatism in, 131, 134-35

Four River Project, 226

geopolitics: KSP and, 107, 111; pragmatism in, 139-40

Global South, 1. See also developing countries

GPN, 111-12

grassroots struggles, 87-93, 88, 90, 92, 94, 95-96

GVCs, 111-12

high-rise apartments and construction, $27,58,69,85,221,223$; as embodying modernity in Vietnam, 121-22 
historical meaning of urban, 82

housing and real estate: evictions, $67,87-88,88,94,170,172$, 175; housing renewal projects, 8 , 170-77, 174; housing shortages and disparities, 83-84, 120 , 151-53, 165; indicators of housing conditions (1980-2015), 169; Joint Redevelopment Project (JRP), 83-85, 89-94, 94, 171-72, 176-77; Korean model of construction in Vietnam, 120-25, 127-28; low-income housing policy and, 167-70, 169; new town developments, 150-53; rent gaps, 64-66, 66; squatters and, 170-72, 182-84, 197; Two Million Housing Construction Plan (TMHCP), 151, 225; ventilation and, 127

Ilsan, South Korea, 150-57

inequitable development, 1-2, 7, 83-84, 151-53, 165. See also grassroots struggles innovation cities, $\mathbf{1 5 3}$

international urban development leadership, 131-32. See also urban development leadership (East Asia)

Joint Redevelopment Project (JRP), 83-85, 89-94, 94, 171-72, 176-77. See also housing and real estate

knowledge market, 3; knowledge production market, 206-9; talents, technology and capital concentrations and, 42-43, 43

Knowledge Sharing Program (KSP), 3-4, 103-6, 105, 111-15; geopolitical economy (GPE) approach to, 107, 111; methodological nationalism approach to, 107-12; modularization, 103-4, 119, 128; need for multiple models in, 119-20, 128-29; new town developments (Korean model) and, 162

Korea Housing Corporation, 219, 221, 223. See also public development corporations (PDCs)

Korea Land Corporation, 219 , 223-25. See also public development corporations (PDCs)

Korea Research Institute for Human Settlements (KRIHS), 159, 202-13, $207,210,211,214$
Korea Water Resource Development Corporation (K-Water), 219, 222; in era of low economic growth, 226-27; land reclamation business and, 219-21. See also public development corporations (PDCs)

land development schemes, 9; land development defined, 182; Land Readjustment (LR) and Public Purchase and Development (PPD) and, 182-98; recommendations for land development, 198-99

land reclamation, 220-21

localities, 81 ; commodification of localities, 81-82, 84-86, 86; transformation of, 83-84

low-income housing policies, 165-66; developing countries and, 166, 173, 177-79; housing disparities and, 16770,170 ; urban growth and, 166-67

mercantilist interests, $2-3$

methodological nationalism approach, 107-10

Ministry of Economy and Finance of Korea (MOEF), 3

Ministry of Foreign Affairs (MOFA), 3

Multifunctional Administrative City (MAC) construction, 213-14, 214

neo-developmentalism, 20-24, 22-23; democratization and, 24-30

new town developments (Korean model), 161-62; implications for overseas development and, 157-61; key factors in success in, 154-57; urbanization in latter half of 20th century and, 150-51

Nigeria, 2

OECD/DAC, 2-4, 103

Official Development Assistance (ODA), 1,6 ; Korea's unique position in international cooperation, 2-3;

Park Chung-hee Government (1963-79), 15

place-based, 35, 43-44, 48, 53; grassroots struggles, $87-88, \mathbf{8 8}$; locality and, 81

policy contexts, 7 ; city government policies, 26-27 


\section{Index}

policy research institutes (PRIs), 202-4, 212; development of, 204-5, 205, 206; government-institute relations and, 209-12, 210, 211; knowledge production market and, 206-9; lessons from, 215; Multifunctional Administrative City (MAC) construction and, 213-14, 214; stateled urban development and, 212-13

population: population decline in Korea, 28 ; population growth in developing countries, 182

property-led urban development, 72-74, 84; commodification of localities and, 81-82, 84-86, 86; Joint Redevelopment Program (JRP), 83-85, 89-94, 94, 171-72, 176-77; post-1980s, 61-72, 66; post-1980s property-based, 61-72, 66

public development corporations (PDCs), 218; competition from local PDCs, 225-26; defined, 218; in high-economic growth era, 220-26; legal basis for, 219; total assets of Top 10, 220. See also Korea Housing Corporation; Korea Land Corporation; Korea Water Resource Development Corporation (K-Water)

regional development: balanced, 35 , $50,52-53$; de-concentration policy and, $45-47,52$; developing countries and, 52 ; dispersion plus regional capacity enhancement and, $47-50$; evolution of regional policies, 43, 44, 45; politico-economic context and underlying processes of, 35-39, 36; regional policy objectives and, $51-52$ regional disparities, 8, 52-53; Central Region (CR) and, 40-43, 41, 42, 43; institutional context and, 39-40

right to the city, 8

Saemaul (New Village) model, 4-5; Saemaul Undong (New Village Movement), 19, 45, 171

Seoul Metropolitan Region (SMR): regional disparity and, 8

Seowon Maeul (Seoul), 91-96, 92, 94

Singapore urban development model, 9, 73, 132-40, 142. See also urban development leadership (East Asia) smart city projects, 151; exportation of to developing countries, 159-61
Songhak Maeul (Seoul), 89-91, 90, 93-96, 94

South Korea. See urban development leadership (East Asia)

South-South Development Cooperation (SSDC), 103

Soyang Dam, 219-20

spatial planning (1960s-80s), $15-20,16,19$

speculative urbanization, 62-64

squatters, 18, 60, 166, 169-72, $182-84,197$

timing, pragmatism in, $131,133-34$

Two Million Housing Construction Plan (TMHCP), 151, 225

UN Habitat and Cities Alliance, 8 United States, 2, 176, 208 urban development: African cities and, 58; city export model and, 5,10 , 103-4, 149, 229-30; grassroots struggles and community engagement against, 87-90, 90, 91-92, 92, 93, $94,95,96,88$; growth and lowincome housing policy and, 166-67; Joint Redevelopment Project (JRP), 83-85, 89-94, 94, 171-72, 176-77; Knowledge Sharing Program (KSP), 103-4, 105; Korean model of as for exportation, $1-5,8,58$, 103-4; Korean model of construction in Vietnam, 120-25, 127-28; methodological nationalism approach to, 107-10; neo-developmentalism in, 20-30, 22-23; post-1980s property-based, 61-72, 66; pre-1980s property-based, 58-61; singular model of $v s$. multiple models, 119-20, 128-29; slowing economic growth and, 218-19; state-led urban development and, 212-13. See also city export model; housing and real estate; Knowledge Sharing Program (KSP); regional development; urban development leadership (East Asia) urban development leadership (East Asia), 131-33, 140-42, 142; pragmatism in administration and, 137-39; pragmatism in emphasis and, 136-37; pragmatism in form and, 131, 134-35; pragmatism in geopolitics and, 139-40; pragmatism in timing and, 131, 133-34 
urbanization: new town developments

(Korean model) and, 150-51; public

development corporations and, 218;

speculative urbanization, 62-64

ventilation, 127

vertical accumulation and cities, 66-67
Vietnam, 5, 9; Korean model of construction in, 120-28, 126; smart city/new town projects in, 149, 151

Western donors, 2

Yongsan Incident (2009), 8 


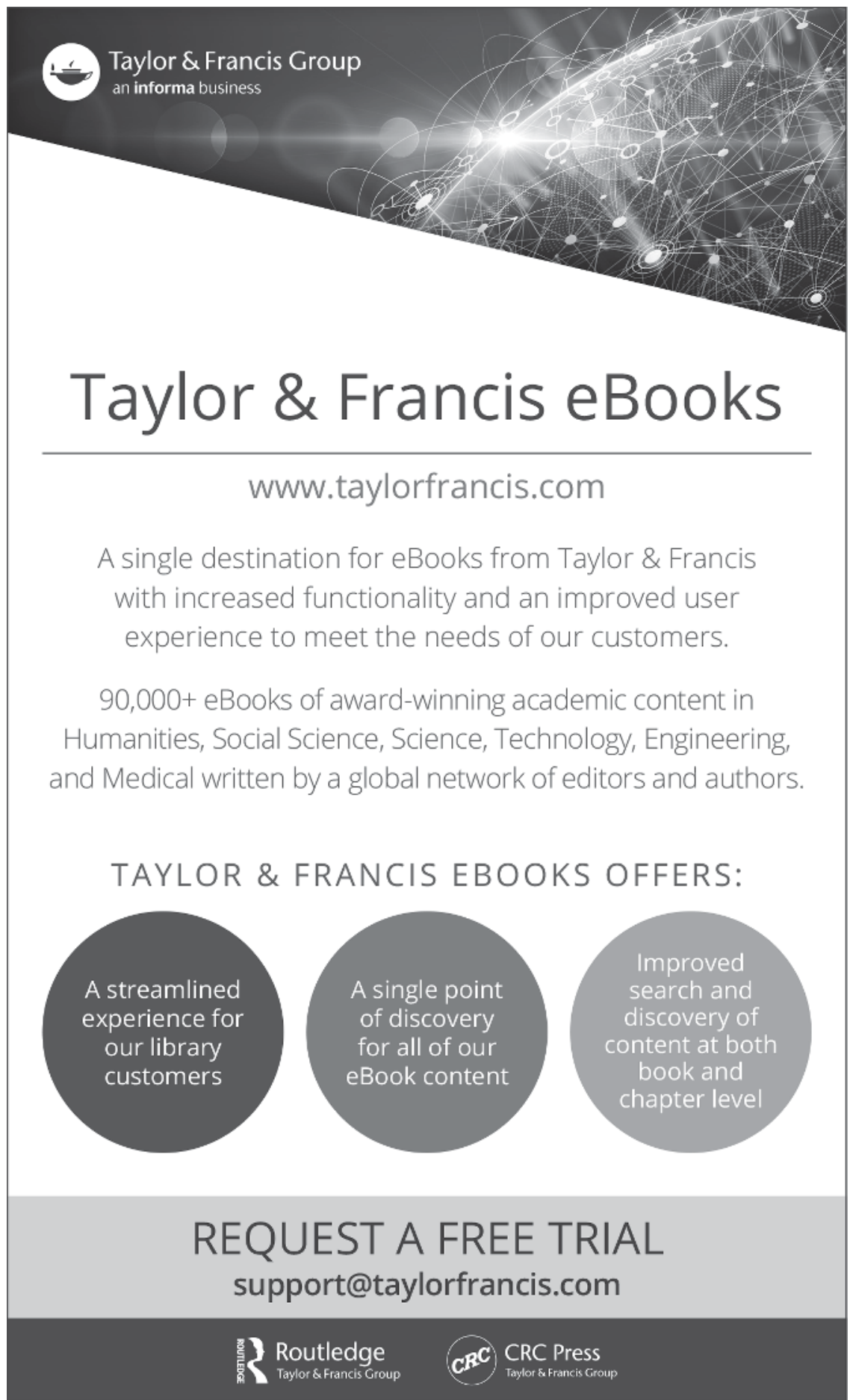

